\title{
IWONA MILEWSKA
}

\section{E U R O P E J S K I E GRAMATYKI SANSKRYTU \\ XVII-XIX WIEK}

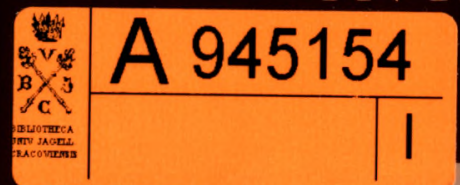




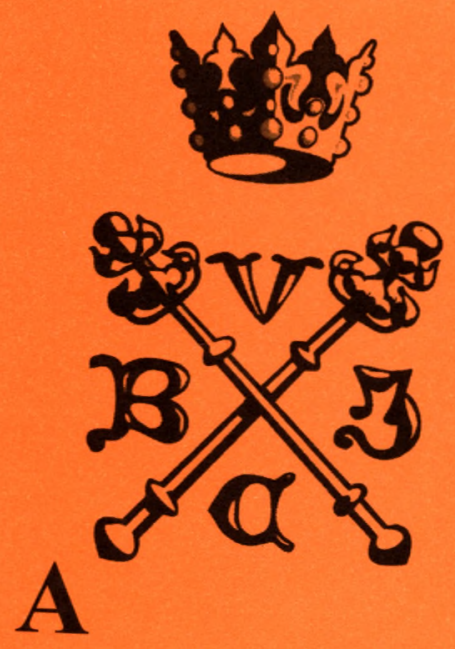






\section{Europejskie gramatyki sanskrytu XVII-XIX wiek}



Iwona Milewska

$$
\begin{array}{r}
\text { Europejskie } \\
\text { gramatyki } \\
\text { sanskrytu } \\
\text { XVII-XIX wiek }
\end{array}
$$


(C) Copyright by Iwona Milewska, 2019

\section{Recenzent}

prof. dr hab. Kazimierz Korus

Redakcja

Patrycjusz Pilawski

Projekt okładki

Paweł Sepielak

Publikacja sfinansowana ze środków Wydziału Filologicznego Uniwersytetu Jagiellońskiego

ISBN 978-83-8138-087-4

DOI https://www.doi.org/10.12797/9788381380874

\section{KSIĘGARNIA AKADEMICKA}

ul. św. Anny 6, 31-008 Kraków

tel./faks: 124312743,124211387

e-mail: akademicka@akademicka.pl

Księgarnia internetowa:

www.akademicka.pl 


\section{Spis treści}

Podziękowania

Zasady transkrypcji naukowej i spolszczania wyrazów sanskryckich

Wstęp

Część I. Historia pierwszych kontaktów europejsko-indyjskich ... 25

Część II. Łacińskie gramatyki sanskrytu - XVII i XVIII wiek..... 43

1. Heinrich Roth, Grammatica linguae Sanscretane Brahmanum Indiae

Orientalis

2. Jean François Pons, Codex chartaceus quo continentur Grammatica el dictionarium linguae samscrelamicae..

3. Johann Ernst Hanxleden, Grammatica Grandonica

4. Paulinus a Sancto Bartholomaeo, Sidharubam seu grammatica

Samscridamica i Vyacarana seu locupletissima Samscridamicae linguae institutio

Część III. Gramatyki sanskrytu w języku angielskim -

XIX wiek.

1. William Carey, $A$ Grammar of the Sungskrit Language ........................ 82

2. James Robert Ballantyne, $A$ Catechism of Sanskrit Grammar ............. $\quad 90$

3. Charles Wilkins, $A$ Grammar of the Sanskrita Language..................... 94

4. Henry Thomas Colebrooke, $A$ Grammar of the Sanscrit Language.... 108

5. Horace Hayman Wilson, An Introduction to the Grammar of Sanskrit Language for the use of early students 
6. Monier Monier-Williams, A Practical Grammar of the Sanskrit language

Część IV. Gramatyki sanskrytu w języku niemieckim -

XIX wiek

1. Franz Bopp, Kritische Grammatik der Sanskrita-Sprache

2. Theodor Benfey, Handbuch der Sanskritssprache zum Gebrauch für

Vorlesungen und zum Selbsstudium

3. Adolf Friedrich Stenzler, Elementarbuch der Sanskrit-Sprache.

Grammatik, Texte, Woerterbuch

4. Georg Bühler, Leitfaden für den Elementarkursus der Sanskrit.

Część V. Gramatyki sanskrytu w języku polskim - XIX wiek .....

1. Walenty Skorochód Majewski, Gramatyka mowy starożyinych

Skuthów czyli Skalnych Gorali, Indo-Skythów, Indyków, Budhynów

Herodota samskrytem czyli dokładnq mowq zwaney

2. Franciszek Xawery Malinowski, Gramatyka sanskrytu porównanego z jezykiem starosłowianiskim i polskim

Część VI. Wybrane słowniki sanskrytu

Część VII. Wybory fragmentów tekstów (chrestomatie)

Zakończenie

Appendyksy

Gramatyki sanskrytu - alfabetycznie.

Gramatyki sanskrytu - chronologicznie

Wybory tekstów oryginalnych / Chrestomatie

(wybrane przykłady) - alfabetycznie

Wybory tekstów oryginalnych / Chrestomatie (wybrane przykłady) chronologicznie

Wybory tekstów pochodzących z określonych dzieł

(wybrane przykłady) - alfabetycznie 
Wybory tekstów pochodzących z określonych dzieł (wybrane przykłady) - chronologicznie ............................................ 214

Spis ilustracji

Bibliografia

Summary

Indeks osobowy 



\section{Podziękowania}

7 a książka powstawała wiele lat. Dlaczego tak długo?

Przede wszystkim ogromnie dużo czasu poświęciłam na zbieranie materiałów potrzebnych do napisania pracy, która spełniłaby moje własne wymagania dotyczące przekrojowego przedstawienia europejskiej tradycji gramatyk sanskrytu powstałych na przestrzeni z górą trzystu lat. Docieranie do oryginalnych źródeł było wielokrotnie nie lada wyzwaniem. Kolejnym niełatwym zadaniem było wyeliminowanie niektórych partii zebranego materiału oraz uporządkowanie go i przedstawienie w formie spójnej i klarownej całości. Moim zamierzeniem było napisanie rzeczy interesującej nie tylko dla wąskiego grona polskich indologów. Czy to się udało? Recenzentami, co oczywiste, będą czytelnicy niniejszej publikacji.

Wszystko to, co zrobiłam do tej pory, było możliwe, gdyż na swojej drodze spotkałam wielu ludzi, którzy pomagali mi w ten czy inny sposób. Jest jasne, że nie uda mi się choćby tylko wymienić ich wszystkich - pozwolę sobie zatem wspomnieć jedynie o tych kilku osobach, których pomoc sprawiła, że książka ostatecznie jest dzisiaj publikowana.

Na początku tej drogi był profesor Gerhard Oberhammer, który umożliwił mi kontakty ze światem naukowym szeroko rozumianego Zachodu - zresztą nie tylko mi, ale i innym osobom z zakładu indologii Uniwersytetu Jagiellońskiego, w relatywnie odległych już czasach końca XX wieku, kiedy nauka polska wracała po długich latach izolacji 
powstałej z powodu ustroju, który zapanował w Polsce po II wojnie światowej. On też sprawił, że udało mi się odbyć niezwykle dla mnie ważną, też dlatego, że pierwszą, kwerendę w bibliotece Uniwersytetu Wiedeńskiego. Było to wtedy niezwykle rzadką sposobnością.

Doktor Przemysław Piekarski z kolei przyczynił się do mojego pierwszego kontaktu z profesorem Kazimierzem Korusem, który od tamtej pory pozostaje moim mentorem, pierwszym krytykiem moich prac i osobą, z którą debaty pozwalają mi uściślać wszystkie moje pomysły natury naukowej. Jest też niezastąpionym przewodnikiem w meandrach mojego życia, nie tylko zawodowego.

Profesor Joanna Sachse, promotorka mojej pracy doktorskiej poświęconej zbliżonemu do przedmiotu niniejszej książki tematowi, także była i jest nadal nieocenionym dla mnie rozmówcą. To właśnie debaty z nią i jej krytyczne uwagi sprawiły, że zarówno mój doktorat, jak i obecna książka przybrały taką właśnie postać.

Kwerendę w niezwykle ważnych dla mnie bibliotekach w Oksfordzie umożliwił mi profesor Richard Gombrich, a w bibliotece uniwersytetu w Lozannie profesor Johannes Bronkhorst. Za to szczerze im dziękuję.

Jednym z pierwszych czytelników wstępnej, napisanej w języku angielskim wersji książki, która ciągle czeka na ostateczne opracowanie, był profesor Klaus Karttunen. Korespondencja z nim właśnie pozwoliła mi na doprecyzowanie niektórych szczegółów, przede wszystkim tych związanych z historią indologii europejskiej, której profesor Karttunen jest wybitnym znawcą.

Niewątpliwie na ostateczny kształt książki miały także wpływ rozmowy z osobami związanymi z moją własną Alma Mater, w tym w szczególności z profesor Haliną Marlewicz, osobą ważną dla mnie nie tylko w wymiarze współpracy naukowej. Stałemu wsparciu profesor Barbary Michalak-Pikulskiej zawdzięczam niewątpliwie fakt doprowadzenia mojej pracy do końca. 
$\mathrm{Na}$ koniec, choć być może koniec ten powinien być początkiem moich podziękowań, chcę napisać, że moja ogromna wdzięczność jest skierowana ku mojej najbliższej rodzinie, mojej Mamie, Siostrze i mojemu Synowi. W szczególności jednak dziękuję mojemu Mężowi, Zdobysławowi Milewskiemu. To jego wsparcie i niezwykła wprost cierpliwość oraz najróżnorodniejszego rodzaju pomoc, w tym przeczytanie przedostatniej wersji książki oraz uwagi, które poczynił, sprawiły, że jej powstanie było możliwe.

Były oczywiście i inne ważne dla mnie osoby, które wspomagały mnie czy to dyskusją, czy radą. Bez nich ta książka nigdy nie zostałaby wydana, choćby ze względu na moją nieustanną chęć jej poprawiania. Oczywiście za wszelkie niedoskonałości jej ostatecznego kształtu odpowiada wyłącznie autorka. 



\section{Zasady transkrypcji naukowej i spolszczania wyrazów sanskryckich}

Zasady transkrypcji naukowej

W pracy przyjęto transkrypcję naukową wyrazów sanskryckich zgodną $\mathrm{z}$ regułami IAST (International Alphabet of Sanskrit Transliteration).

\section{Zasady spolszczania}

Zachowano następujące reguły spolszczania wyrazów sanskryckich:

$$
\begin{array}{lll}
\mathrm{a}, \overline{\mathrm{a}} & - & \mathrm{a}, \mathrm{A} / \mathrm{a}, \mathrm{A} \\
\mathrm{i}, \overline{\mathrm{i}} & - & \mathrm{i}, \mathrm{I} / \mathrm{i}, \mathrm{I} \\
\mathrm{u}, \overline{\mathrm{u}} & - & \mathrm{u}, \mathrm{U} / \mathrm{u}, \mathrm{U} \\
\mathrm{r} & - & \mathrm{ri}, \mathrm{Ri} \\
\mathrm{e} & - & \mathrm{e}, \mathrm{E} \\
\mathrm{ai} & - & \mathrm{aj}, \mathrm{Aj} \\
\mathrm{o} & - & \mathrm{o}, \mathrm{O} \\
\mathrm{au} & - & \mathrm{au}, \mathrm{Au} \\
\mathrm{k}, \mathrm{kh} & - & \mathrm{k}, \mathrm{kh} / \mathrm{K}, \mathrm{Kh} \\
\mathrm{g}, \mathrm{gh} & - & \mathrm{g}, \mathrm{gh} / \mathrm{G}, \mathrm{Gh} \\
\dot{\mathrm{n}} & - & \mathrm{n}, \mathrm{N} \\
\mathrm{c}, \mathrm{ch} & - & \mathrm{cz}, \mathrm{czh} / \mathrm{Cz}, \mathrm{Czh} \\
\mathrm{j}, \mathrm{jh} & - & \mathrm{dż}, \mathrm{dz} h / \mathrm{D}, \mathrm{D} \dot{\mathrm{h}} \\
\mathrm{n} & - & \mathrm{n}
\end{array}
$$




\begin{tabular}{|c|c|c|}
\hline t, th & - & $\mathrm{t}, \mathrm{th} / \mathrm{T}, \mathrm{Th}$ \\
\hline $\mathrm{d}, \mathrm{d} h$ & - & $\mathrm{d}, \mathrm{dh} / \mathrm{D}, \mathrm{Dh}$ \\
\hline$?$ & - & $\mathrm{n} / \mathrm{N}$ \\
\hline th & - & $\mathrm{t}, \mathrm{th} / \mathrm{T}, \mathrm{Th}$ \\
\hline $\mathrm{d}, \mathrm{dh}$ & - & $\mathrm{d}, \mathrm{dh} / \mathrm{D}, \mathrm{Dh}$ \\
\hline n & - & $\mathrm{n} / \mathrm{N}$ \\
\hline p, ph & - & $\mathrm{P}, \mathrm{ph} / \mathrm{P}, \mathrm{Ph}$ \\
\hline $\mathrm{b}, \mathrm{bh}$ & - & $\mathrm{b}, \mathrm{bh} / \mathrm{B}, \mathrm{Bh}$ \\
\hline m & - & $\mathrm{m}, \mathrm{M}$ \\
\hline y & - & $\mathrm{j}, \mathrm{J}$ \\
\hline 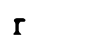 & - & $\mathrm{r}, \mathrm{R}$ \\
\hline 1 & - & l, L \\
\hline $\mathbf{v}$ & - & $\mathbf{w}, \mathbf{W}$ \\
\hline$\dot{s}, \underline{s}, s$ & - & $\dot{s}, \mathbf{s z}, \mathbf{s} / \dot{S}, \mathrm{Sz}, \mathrm{S}$ \\
\hline $\mathrm{h}$ & - & $\mathrm{h}, \mathrm{H}$ \\
\hline$m$ & - & $\mathrm{m}, \mathrm{M}$ \\
\hline h & - & h, H \\
\hline
\end{tabular}

Przy pierwszym pojawieniu się wyrazu sanskryckiego w tekście polskim w nawiasie podano jego wersję w transkrypcji naukowej, w postaci tematu. Imiona i nazwy własne w tekście polskim pisane są z użyciem dużej litery na początku terminu. Wyrazy spolszczone ulegają odmianie, zgodnie $z$ regułami języka polskiego. 


\section{Wstęp}

$\mathrm{H}$

istoria powstawania nowożytnych gramatyk sanskrytu napisanych przez badaczy europejskich liczy sobie prawie 400 lat. W mojej książce zamierzam przedstawić i poddać analizie te, które napisano od XVII do końca XIX stulecia. Dlaczego właśnie ten okres uznałam za szczególnie znaczący w dziejach kształtowania się tradycji europejskiej? Powodem było to, że wówczas ukształtowała się - kontynuowana aż do czasów współczesnych - tradycja, w ramach której można wyróżnić najważniejsze stosowane przez Europejczyków metody opisu sanskrytu.

Gramatyczne narzędzia wypracowane w tym właśnie czasie uzyskały wstępną dojrzałość. Tym samym pozwoliły na recepcję podstawowych elementów kultury i klasycznej literatury indyjskiej, wprowadzając ją w zakres szeroko rozumianej humanistyki Zachodu. W ten sposób zakończyła się pewna epoka obcowania Europy z Indiami.

Z zakresu tematyki szczegółowo przedstawionej w książce wyłączyłam dokonania wieku XX i XXI. Powodów tego ograniczenia jest co najmniej kilka. Po pierwsze, w omawianym przeze mnie okresie można wyróżnić w zasadzie wszystkie podstawowe trendy metodologiczne stosowane do tej pory w opisie gramatyki sanskrytu. Sam opis i analiza dokonań XVII-, XVIII- i XIX-wiecznych pozwala zatem na przedstawienie syntetycznych wniosków co do samej zawartości gramatyk, ich struktury, jak i stosowanych w nich metod opisu. Analiza tylko tych opracowań pozwala także na ustalenie potencjalnych źródeł informacji o sanskrycie, do których Europejczycy mieli i mają dostęp 
w przygotowywaniu własnych opracowań. Po drugie, sam temat europejskiej drogi do poznawania gramatyki sanskrytu jest niezwykle obszerny nawet wtedy, gdy opis dotyczy tych początkowych z górą 300 lat, choćby ze względu na liczbę powstałych w jego trakcie gramatyk. $\mathrm{Z}$ moich dotychczasowych ustaleń wynika, że powstało ich wtedy co najmniej kilkadziesiąt, i te właśnie starałam się uwzględnić w przeprowadzonej w książce analizie.

Wiek XX to pojawienie się wielu kolejnych pozycji. Po wstępnym zebraniu informacji na ich temat mogę stwierdzić, że nie przynoszą one, $w$ porównaniu $z$ omawianymi przeze mnie, na tyle nowych odkryć, by można było je nazwać przełomowymi dla europejskiej tradycji. Z pewnością i ten okres doczeka się szczegółowego opracowania. Wykracza on jednak poza zamierzone przeze mnie ramy czasowe niniejszej książki. Dopiero doba internetu, która zaczęła się relatywnie niedawno, powoduje, że można mówić o pojawieniu się nowych sposobów opisu. Prawdopodobnie nowatorstwo stosowanych metodologii będzie tematem wartym opracowania w przyszłości. Zróżnicowane źródła informacji na temat gramatyki sanskrytu pojawiają się obecnie prawie każdego dnia. Co więcej, są niemal natychmiast powszechnie dostępne. Niewątpliwie problemem jest tylko wybór wiarygodnych opracowań. Dlatego nadal ci, którzy chcą poznać tajniki gramatyki sanskrytu, relatywnie często korzystają z opracowań tradycyjnych, także i z tych, które powstały do końca XIX wieku. Za wyłączeniem z zakresu tematyki podjętej w tej pracy opracowań XX- i XXI-wiecznych przemawia także moja chęć skupienia się tylko na tradycji europejskiej. Obecnie należałoby spróbować przedstawić trendy, które pojawiły się i pojawiają w obszarze nauki, nie tylko europejskiej, ale także ogólnoświatowej. Myślę, że to praca możliwa do podjęcia w przyszłości.

Co jeszcze było jednym z głównych powodów, które sprawiły, że podjęłam próbę przekrojowego opisu europejskiej tradycji poznawa- 
nia gramatyki sanskrytu w okresie od XVII do końca XIX wieku? Niewątpliwy wpływ na moją decyzję miał brak takiego przekrojowego opracowania, w ramach którego zebranoby informacje na temat gramatyk powstałych w tym czasie, tak ważnym dla kształtowania się europejskiej tradycji nowożytnych jej opisów. Chciałam podjąć próbę określenia głównych trendów w europejskich opisach sanskrytu oraz przeanalizować metodologie, które stosowano w jego deskrypcji również dlatego, że nikt do tej pory nie podjął się próby syntetycznego ujęcia całości zagadnienia. Publikowane prace obejmują książki i artykuły, w których najczęściej zajmowano się poszczególnymi gramatykami i ich autorami.

Tak właśnie jest np. w przypadku gramatyki, która obecnie jest uznawana za pierwszy europejski opis sanskrytu, czyli pracy zatytułowanej Grammatica linguae Sanscretanae Brachmanum Indiae Orientalis Heinricha Rotha. Dzieło to, mimo że napisane już w roku 1660, zostało odnalezione dopiero w latach 70. XX wieku i, po szczegółowym opracowaniu, wydane przez A. Campsa i J.-C. Mullera dopiero w roku 1988. Krytyczna praca tych autorów, uzupełniona o przegląd niewielu wydanych do tej pory artykułów odnoszących się do tego i innych jeszcze dokonań autora gramatyki (w tym np. pochodzących z końca lat 80. XX wieku artykułów B. Zimmela dotyczących odnalezionych listów i manuskryptów autorstwa Rotha czy wydanych pod koniec XX wieku artykułów $\mathrm{R}$. Hauschilda, w których zebrał on dane na ten temat), jest podstawą, na której oparłam część mojej pracy poświęconą tej gramatyce.

Podobnie jest z opracowaniem, które dotyczy odnalezionej po długim okresie poszukiwań gramatyki autorstwa Johanna Ernsta Hanxledena, zatytułowanej Grammatica Grandonica. Tak jak w poprzednim przypadku została ona "odkryta” setki lat po jej napisaniu i wydana dopiero w roku 2013 w opracowaniu Ch. Vielle'a i T. Van Hala. Przygotowane przez nich wydanie krytyczne oraz ich artykuły 
były dla mnie dobrą podstawą do uogólnień dotyczących gramatyk powstałych w pierwszej fazie poznawania sanskrytu przez Europejczyków i zachowanych jedynie w formie manuskryptów.

W odniesieniu do jednej z najważniejszych gramatyk pochodzących z przełomu wieków XVIII i XIX za najlepsze opracowania uznaje się powstałe w latach 70. i 80. XX wieku prace Ludo Rochera. To one, a w szczególności krytyczne opracowanie książki zatytułowanej Sidharubam seu grammatica Samscridamica, stanowią podstawę moich badań dzieł Paulinusa a Sancto Bartholomaeo. To one właśnie zostały jako pierwsze wydane drukiem w Europie. Na temat samego Paulinusa ukazało się do tej pory niewiele prac. Można tu wymienić dla przykładu obszerny artykuł M. Jauk-Pinhak Some notes on the pioneer indologist Filip Vesdin (Paulinus a Sancto Bartholomaeo). Rzecz najnowsza dotycząca jego idei to opublikowany w 2017 roku artykuł 1. Andrijanicia dotyczący wspólnej etymologii słów sanskryckich i łacińskich. W przypadku tych powyższych trzech gramatyk nie miałam dostępu do oryginalnych manuskryptów.

Z kolei większość gramatyk XIX-wiecznych była mi dostępna bezpośrednio, to na ich lekturze oparłam mój własny opis i analizę. W odniesieniu do nich trudno znaleźć źródła, w których poddawanoby refleksji stosowaną $w$ przedstawianiu podstaw gramatyki sanskrytu metodologię. Nie sposób także stwierdzić, by ktokolwiek, łącznie z samymi ich autorami, analizował czy uzasadniał wybór omawianych w gramatykach zagadnień gramatycznych. Taka refleksja nad metodologią pojawiła się dopiero w XX wieku. Także tutaj jest raczej wyjątkiem niż regułą. Kompleksowe uzasadnienie stosowanej metody pojawia się właściwie jedynie w wydanej po raz pierwszy w roku 1990 gramatyce autorstwa A. Aklujkara, zatytułowanej Sanskrit. An Easy Introduction to an Enchanting Language. Moja analiza dotyczy zatem tych właśnie przez wieki zapoznanych zagadnień. 
Oczywiście korzystanie zarówno ze źródeł oryginalnych, jak i z opracowań teoretycznych uwarunkowane było dostępem do nich, dlatego nie mogę stwierdzić, że przebadałam wszystkie wiążące się $z$ tematem mojej książki prace.

Metoda, którą przyjęłam, polega na szczegółowym opisie i analizie poszczególnych dzieł, które zostaną przedstawione w porządku chronologicznym. Taka struktura tekstu pozwoli, w moim przeświadczeniu, na pokazanie, jak stopniowo rozwijały się coraz to nowsze sposoby opisu gramatyki sanskrytu, jakiej ewolucji podlegały te już wcześniej powstałe, oraz na uwidocznienie i szczegółowe przedstawienie poszczególnych faz ich rozwoju. Umożliwi także wskazanie na ewentualne zależności określonych opracowań od tych powstałych wcześniej oraz pokazanie trendów, które mają wpływ na współcześnie pisane gramatyki.

Jako że moja książka obejmuje swym zakresem opis odnalezionych do tej pory dzieł powstałych w nowożytnej europejskiej tradycji, jako pierwsze przedstawiam prace, które stworzono na początku tejże, uwzględniając także, w szczegółowej analizie, ewentualne nowatorskie sposoby opisu samej gramatyki. Tutaj wybrałam zatem najważniejsze gramatyki, powstałe na przestrzeni wieków od XVII do końca XVIII. Ponieważ zaś w wieku XIX Europejczycy stworzyli i wydali bardzo dużo gramatyk sanskrytu, kryterium, które zastosowałam przy wyborze tych opisywanych szczegółowo, była ich typowość. Okres ten wyróżnia się tym, iż oryginalne gramatyki pisane były przede wszystkim przez badaczy brytyjskich i niemieckich. Ci pierwsi korzystali bezpośrednio ze źródeł indyjskich. Jako typowe omawiam szczegółowo prace W. Careya, J. R. Ballantyne’a, Ch. Wilkinsa i H. T. Colebrooke'a. Ci drudzy posiadali przede wszystkim wiedzę pośrednią, jako osoby, które często osobiście nigdy Indii nie odwiedziły. W poświęconej im części książki przedstawiam przede wszystkim gramatyki badaczy uznanych powszechnie za autorytety. To ich opisy 
i sposoby ustrukturyzowania tychże wyznaczyły na lata podstawowe trendy $w$ badaniach nad sanskrytem. Za takich na pewno można uznać F. Boppa oraz A. Stenzlera. Piszę też o T. Benfeyu i G. Bühlerze, jako o jednych z pierwszych, którzy stworzyli gramatyki typu podręcznikowego.

Analizę głównych trendów metodologicznych rozszerzyłam w większości konkretnych opisów o wiadomości dotyczące relacji europejsko-indyjskich w następujących po sobie fazach ich rozwoju. Informacje na temat samych gramatyk uzupełniam także o dane dotyczące biografii poszczególnych autorów. Jaką drogą Europejczycy dochodzili do możliwości poznawania nie tylko współczesnych im języków, którymi mówiła ludność lokalna, ale także języka świętych ksiąg indyjskich, którego znajomość była także w Indiach ograniczona do grona osób pochodzących $\mathrm{z}$ najwyższych warstw społeczeństwa? Jakie indyjskie gramatyki i inne teksty mogły stanowić podstawę opisów dokonywanych przez Europejczyków? Czy da się zauważyć wpływ metod stosowanych w opisach gramatyki stosowanych wtedy w Europie na sposób przedstawiania gramatyki sanskrytu? Do kogo autorzy gramatyk kierowali swe teksty? $\mathrm{Na}$ te i inne pytania starałam się znaleźć odpowiedź, przygotowując moją książkę.

Wiek XVII jako epoka, w której Europejczycy zaczęli badać kulturę indyjską, a w szczególności języki, w sposób naukowy, to czas, kiedy do Indii docierali pierwsi europejscy misjonarze i pozostawali tam w celu chrystianizacji ludności lokalnej. Za ważną postać tego okresu, za osobę, która jako pierwsza pozostawiła zapisane po łacinie dzieła, w których można znaleźć opis zagadnień istotnych dla zrozumienia Indii starożytnych, i za pierwszego, który wspomniał o dziale wiedzy dotyczącym gramatyki, jest uważany Roberto Nobili. Dlatego, mimo że to nie on napisał pierwszą europejską gramatykę sanskrytu, jeden z pierwszych fragmentów książki poświęcony jest właśnie jemu. Kolejny to szczegółowy opis i analiza wspominanego 
już dzieła gramatycznego, które przynosi informacje na temat sanskrytu, autorstwa żyjącego w XVII wieku jezuity Heinricha Rotha. Część następna dotyczy pierwszych europejskich gramatyk wydanych drukiem, czyli prac Paulinusa a Sancto Bartholomaeo. Jako że w świetle najnowszych badań jest bardzo prawdopodobne, iż jednym z najważniejszych źródeł dla Paulinusa były prace Johannesa Ernsta Hanxledena, to właśnie im jest poświęcony fragment książki. Przedmiotem opisu są także dzieła kilku innych europejskich misjonarzy, które stopniowo docierały do Europy.

Kolejną opisaną w książce epoką jest czas, kiedy w Indiach pojawili się misjonarze baptyści, na czele $\mathbf{z}$ Williamem Careyem, oraz badacze sanskrytu związani z działalnością Kompanii Wschodnioindyjskiej. To pierwsza połowa wieku XIX. Wielu z nich stało się później autorami własnych gramatyk sanskrytu. Im i ich dziełom poświęcam następne strony książki. W'́ród nich przede wszystkim omawiam dzieła Jamesa Roberta Ballantyne'a, Charlesa Wilkinsa i Henry'ego Thomasa Colebrooke'a, ale także inne mniej znaczące prace. Poszczególni autorzy przyjmowali swoje własne metody opisu, dlatego już wtedy można wyróżnić kilka odrębnych trendów w samym sposobie przedstawiania gramatyki sanskrytu oraz w określonym wyborze opisywanych zagadnień gramatycznych. Niewątpliwie różnice te wynikały także z opierania własnych prac na różnych gramatykach indyjskich. W książce wskazuję zatem, gdzie to jest możliwe, na te właśnie prawdopodobne źródła. Opisuję też szerzej środowisko skupione wokół postaci Williama Jonesa, założyciela wpływowego w owych czasach ${ }_{n}$ Asiatic Society of Bengal", przyjmując za kryterium jego wkład w dziedzinę przybliżania Europie kultury indyjskiej nie tylko przez pryzmat gramatyki sanskrytu, ale także przez dokonania w zakresie czy to wydawania pierwszych krytycznych opracowań oryginalnych tekstów sanskryckich, czy też ich pierwszych tłumaczeń na języki europejskie. 
Kolejną część książki poświęcam okresowi, kiedy wiedza o sanskrycie dotarła do Europy i spowodowała, że wielu autorów, w szczególności językoznawców niemieckich, nim się zainteresowało. Przede wszystkim omawiam dzieła Franza Boppa, którego prace stanowiły i nadal stanowią podstawę tworzonych gramatyk porównawczych. Także i te prace sprawiły, iż w Europie pojawiło się ogromne zainteresowanie Indiami.

W drugiej połowie XIX wieku powstało relatywnie bardzo dużo gramatyk sanskrytu. W wielu z tych prac autorzy kontynuowali powstałą wcześniej tradycję gramatyk opisowych. Takie były np. gramatyki Moniera Moniera-Williamsa czy Theodora Benfeya. To właśnie wtedy, w roku 1864, swoją gramatykę napisał też Adolf Stenzler. Została ona wydana w Berlinie i stała się na długie lata wzorem dla pozostałych, powstających czy to w Niemczech, czy w innych krajach europejskich. Wtedy też pojawiła się tendencja, by opisywać sanskryt z ukierunkowaniem na cele dydaktyczne, co także znalazło wielu naśladowców w późniejszej, XX-wiecznej już tradycji. Taką gramatyką była np. ta napisana przez Georga Bühlera. Kolejną część książki poświęciłam zatem temu właśnie okresowi, jako znaczącemu w dziejach powstawania nowożytnych gramatyk sanskrytu napisanych przez Europejczyków i zarazem mającemu ogromny wpływ na dzisiejsze opracowania.

Pominęłam w swojej analizie gramatyki sanskrytu, które powstawały w okresie od XVII do XIX wieku w innych niż angielski i niemiecki językach europejskich. Prace te miały charakter wtórny, nie można w nich odnaleźć nowych trendów metodologicznych różniących się zasadniczo od tych przedstawionych przeze mnie. Często były to po prostu tłumaczenia $z$ angielskiego bądź niemieckiego, czasem rozbudowane. Informacje bibliograficzne na ich temat zamieszczam w apendyksach. 
Wyjątek poczyniłam jedynie dla dwóch gramatyk w języku polskim. Ich autorami byli tworzący na początku XIX wieku Walenty Skorochód-Majewski oraz piszący swe prace pod koniec XIX wieku Franciszek Xawery Malinowski. Ponieważ książka skierowana jest do polskiego czytelnika, wydaje się zasadne, by informacje o dziełach właśnie polskich autorów wyróżnić w postaci odrębnej części i zaprezentować je na tle ogólnych tendencji europejskich opisów sanskrytu, które powstawały w wieku XIX, oraz wskazać na ich podstawowe źródła. Ten sam powód sprawił, iż zdecydowałam się dołączać w trakcie całego opisu dziejów poznawania i opisywania sanskrytu przez Europejczyków także podstawowe informacje dotyczące polskich prac mogących przybliżyć rodzimemu czytelnikowi przekłady sanskryckich dzieł literackich.

Ta główna część książki uzupełniona jest o krótki przegląd najważniejszych powstałych w omawianym okresie i używanych do tej poru słowników sanskrytu stworzonych przez Europejczyków. Zawiera także opis przykładowo wybranych, wydawanych jako osobne opracowania wyborów fragmentów tekstów sanskryckich. Te ostatnie używane były jako praktyczne uzupełnienie wiadomości zawartych w publikowanych w Europie gramatykach i miały służyć praktycznemu opanowaniu zdobytej wcześniej wiedzy teoretycznej.

Podsumowanie jest próbą wydzielenia charakterystycznych dla europejskiej tradycji nurtów w opisach gramatyki sanskrytu powstałych na przestrzeni prawie 300 lat, obejmujących wieki XVII-XIX. W zakończeniu zawarłam też propozycje odpowiedzi na postawione we wstępie pytania.

Ponieważ zależało mi na tym, by ułatwić czytelnikom korzystanie ze źródeł bibliograficznych dotyczących szczegółów związanych z samymi gramatykami, słownikami i wyborami fragmentów tekstów, zaopatrzyłam książkę w kilka apendyksów. Pierwszy to alfabetyczny spis europejskich gramatyk sanskrytu powstałych na przestrzeni 
XVII-XIX wieku. Drugi spis, ten sam co do zakresu, został uporządkowany chronologicznie ze względu na moje przeświadczenie o tym, że on właśnie powinien umożliwić szybkie zapoznanie się ze stopniowym rozwojem tradycji. Podobnie, w dwóch porządkach, zostały przedstawione bibliografie wybranych europejskich słowników sanskrytu oraz wyborów fragmentów tekstów sanskryckich. Całość zamyka streszczenie $w$ języku angielskim. Książka zawiera też indeks nazwisk, ze szczególnym wyróżnieniem autorów gramatyk. 


\section{Część I}

\section{Historia pierwszych kontaktów europejsko-indyjskich}



uropejczycy interesowali się zamorskimi lądami od wieków. W kręgu ich zainteresowania relatywnie szybko znalazły się także Indie. Jedne $z$ pierwszych informacji o starożytnym języku kultury indyjskiej, sanskrycie i o zapisywanej w nim literaturze Europa uzyskała już w czasach, kiedy na obrzeża Indii właściwych dotarł Aleksander Wielki ${ }^{1}$. Jeden z polskich badaczy, żyjący na przełomie XIX i XX wieku, który w kręgu swoich zainteresowań umieścił także Indie, Julian Adolf Święcicki, tak pisał w swojej Historyi literatury indyjskiej o tym właśnie okresie

\section{HITTORY LITERATURY POHSEECHES}



Juliana Adolfu Striecichieyo.

$$
\text { - Tuiniv. }
$$

LITERATURA INDYSKA.

$$
2+004
$$

WARSZAWA. DAUnARATA

2. I: Jekleroklego 47. Now -sires 4 .

1. Julian Adolf Święcicki, Historya literatury indyjskiej, strona tytułowa i o poznaniu sanskrytu przez współczesnych Aleksandrowi: „J̨̧zyk sanskrycki, oraz literaturę w tym języku odkrył pierwszy Aleksander Wielki, zdobywca części krajów indyjskich”. Dodawał jednak: „Ale ani ten wielki Macedończyk i jego towarzysze, ani też uczeni wszystkich wieków następnych nie domyślali

Szerzej na ten temat pisze wielu autorów, m.in. W. Halbfass, Indie i Europa. Próba porozumienia na gruncie filozoficznym, przeł. M. Now a kowska, R. Piotrowski, Warszawa 2008. 
się nawet, że sanskryt stoi w takim samym stosunku pokrewieństwa do greki i łaciny, jak język francuski do hiszpańskiego lub włoskiegon2.

Już żyjący w V wieku p.n.e. Herodot tak opisywał tereny, gdzie żyli, jak ich nazywał, Indowie: ${ }_{\text {} N a} \mathrm{Nschód} \mathrm{od} \mathrm{kraju} \mathrm{indyjskiego} \mathrm{są}$ tylko piaski, bo ze wszystkich ludów Azji, które znamy i o których istnieje jakaś pewniejsza tradycja, pierwsi od strony jutrzenki i wzejścia słońca mieszkają Indowie, od Indów zaś na wschód leżące terytorium jest pustynią piaszczystą". Pisał też o używanych przez nich językach: "Wiele jest ludów indyjskich, które nie mówią tym samym językiem, jedne z nich są koczownicze, drugie nie" ${ }^{3}$. W dalszej części opisy wał ich dziwne obyczaje. To zresztą miało stać się tradycją i w późniejszych opisach pierwszych kontaktów Europejczyków z ${ }_{n}$ Indamin. Dopiero w XVIII wieku, jak pisze Klaus Karttunen we wstępie do książki India in early Greek literature, źródłami greckimi, pochodzącymi z często niepełnych, ale jednak zachowanych tekstów, zainteresował się Hadrianus Reland(us), próbując pokazać, iż starożytne języki pozostawały w relacji do języka perskiego. Starał się zebrać wspominane w źródłach greckich i łacińskich słowa „indyjskie” i porównać je z występującymi we współczesnym mu języku perskim. Mimo że starał się zrobić to jak najlepiej, większość jego etymologii była nietrafna ${ }^{4}$. Kiedy mowa o tych właśnie nietrafnych porównaniach, warto wspomnieć, że Reland nie był jedynym, który takie właśnie błędy czynił. Nie inaczej działo się, gdy jeden z pierwszych (czy może nawet pierwszy) Polaków, który zainteresował się poważnie sanskrytem, Walenty Skorochód

2 J. A. Święcicki, Historya literatury indyjskiej, Warszawa 1901, s. 8-9 (zachowuję pisownię oryginalną).

3 Herodot, Dzieje, przeł. i oprac. S. Ham mer, Warszawa 2003, s. 207.

$4 \quad$ K. Karttunen, India in early Greek literature, Helsinki 1989, s. 5. 
Majewski, próbował wykazać, jak blisko sanskryt jest spokrewniony z językiem polskim 5 .

Podczas kolejnych stuleci nastąpiło znaczne osłabienie wcześniej intensywnych kontaktów między Europą a Indiami. Rolę pośredników w przekazywaniu informacji do Europy przejęli w dużej mierze kupcy arabscy, a dopiero później stopniowo przyjeżdżający na tereny indyjskie Europejczycy. Ci ostatni na początku pojawiali się w Indiach bardzo rzadko, a ich wizyty praktycznie nie wpływały na podniesienie poziomu europejskiej wiedzy o tym krajú ${ }^{\circ}$.

Dopiero koniec XV wieku, a dokładnie rok 1498, kiedy to statki pod wodzą Vasco da Gamy (1460/1469-1524) dotarły drogą morską z Europy do zachodnich wybrzeży Indii, do Kerali, a konkretnie do miejscowości Kalikat na południowo-zachodnim wybrzeżu, przyniósł nowe informacje o Indiach. Kolejne wyprawy portugalskie dotarły do Koczinu, gdzie ustanowiono faktorię handlową. Misje portugalskie miały przede wszystkim znaczenie handlowe. Właściwie nie dążono do osiągnięcia panowania na zamieszkiwanych przez Europejczyków terenach. W roku 1505 powołano do istnienia Estado da Índia, organizację mającą ułatwić Portugalczykom ich rozmaite działania w Indiach. Były to działania przede wszystkim natury kupieckiej. Wtedy też przybył do Indii Francisco de Almeida (1450-1510), ustanowiony

5 Dokładniejsze informacje o Walentym Skorochodzie Majewskim znajdują się w dalszej częśsi książki.

- Jak pisze M. K. Byrski: „Do ponownego spotkania w czasach nowożytnych doprowadzili Europejczycy, których ciekawość świata, nie pozbawiona pragmatycznych motywacji handlowych, zaprowadziła do Azji Południowej, gdzie przedsiębiorczy kupcy szukali przypraw, złota, tkanin jedwabnych i przygód. Towarzyszący kupcom misjonarze wkrótce mieli się stać prekursorami systematycznych badań - przede wszystkim nad religią, ale też nad szeroko rozumianym dorobkiem kulturowym odwiedzanych krajów" (por. M. K. Byrski, Dramat staroindyjski. Bhasa - Kalidasa, przeł., wstęp i oprac. M. K. Byrski, Wrocław 2017, s. VI). 
pierwszym wicekrólem portugalskim nad posiadłościami azjatyckimi. Swoją bazą uczynił on Koczin, skąd kierował rozwojem portugalskiej wymiany handlowej i zabezpieczaniem interesów kupców. Wkrótce po nim, bo już w roku 1509, rządy rozpoczął Afonso de Albuquerque (1453-1515). To właśnie ten ostatni jest uważany za twórcę portugalskiej obecności w Indiach. To za jego władania, w roku 1510, zdobyto Goa, gdzie powstała z czasem niewielka portugalska kolonia. I to właśnie Goa ustanowiono stolicą Estado da Índia, zrzeszającą kilkadziesiąt faktorii, miast i fortec ustanowionych przez Portugalczyków. Znaczenia ich pobytu i działań w Indiach nie można pominąć, nie należy ich jednak przeceniać. Z czasem zaczęli tracić swoje posiadłości. W 1661 roku stracili, na rzecz Brytyjczyków, Bombaj, a w dalszych latach większość ich posiadłości zostało przejętych przez imperium Marathów. Portugalczycy od początku swej obecności w Indiach poza działalnością handlową prowadzili też działania misyjne. Ich starania w tej dziedzinie nie były jednak uwieńczone wielkimi sukcesami.

Wkrótce w Indiach pojawili się także Holendrzy i Anglicy i to z nimi właśnie przyszło Portugalczykom rywalizować. Holendrzy swoje starania o podbój, przede wszystkim handlowy, rozpoczęli już na początku XVII wieku. Ich działania trwały do początków wieku XIX. Nie miały one charakteru zbrojnego, za najważniejszy cel uważali bowiem ustanowienie stosunków handlowych. Handlowali przede wszystkim indygiem, jedwabiem, drogocennymi kamieniami, pieprzem, opium i saletrą. Byli obecni w Koczinie, Masulipattam, Nagapatam, Pondicherry i Pulicat.

Wiadomości o samej gramatyce sanskrytu jako pierwsi dostarczyli misjonarze, którzy do Indii przybywali stopniowo, przede wszystkim w celu chrystianizacji ludności lokalnej. Uzyskiwanie informacji na temat świętego języka Indii, jakim niewątpliwie jest sanskryt, nie należało do zadań łatwych. Znajomość sanskrytu dostępna była jedynie wyższym warstwom społeczeństwa indyjskiego, przede wszystkim 
członkom warstwy najwyższej, kapłanom czy inaczej braminom. Szerokie kręgi społeczeństwa nie były dopuszczane do jego znajomości? W szczególności Europejczycy, którzy przez braminów byli uważani za barbarzyńców ${ }^{8}$, za tych, którym nie należy udzielać wiedzy mogącej pomóc w poznawaniu świętych ksiąg hinduizmu9. Nie inaczej zresztą wielu $z$ europejskich przybyszy traktowało braminów. Za przykład takiego myślenia o miejscowych kapłanach mogą posłużyć fragmenty listu Franciszka Ksawerego, znanego także jako Francesco Xavier (1506-1552), uznanego później za świętego, z pochodzenia Baska, pierwszego misjonarza Towarzystwa Jezusowego do Indii. List ten wysłał z Indii 15 stycznia 1544 roku do swoich współbraci jezuitów:

Wśród mieszkańców Wybrzeża Rybackiego jest pewien rodzaj ludzi, których zwie się braminami. Szerzą fałszywą religię i podtrzymują ją wśród pogan. Opiekują się przybytkami, w których znajdują się wyobrażenia ich bóstw. Są najnikczemniejszymi ze wszystkich śmiertelnych, jacy chodzą po tej ziemi. [...] Jest to typ ludzi nigdy nie mówiących szczerze, co myślą. Nieustannie knują między sobą, w jaki sposób za pomocą swoich podstępów usidlić prostych, biednych ludzi [...]. Bramini nie odznaczają się zbytnią dzielnością, ani

7 Wyraz „bramin” jest spolszczoną wersją sanskryckiego terminu „brahmana" (brāhmana), który zgodnie ze słownikiem M. Moniera-Williamsa znaczy w tym kontekście tyle, co one who has divine knowledge, a Brāhman, a man belonging to the 1st of the 3 twice-borne classes and of the 4 divisions of the Hindū body (generally a priest)", M. Monier-Willia ms, A Sanskrit-English Dictionary etymologically and philologically arranged with special reference to cognate Indo-European languages, Delhi 1993, s. 741.

^ Używano na ich określenie sanskryckiego terminu "mleccha".

9 Chodziło m.in. o święte księgi hinduizmu, takie jak np. Rigweda (Rgveda) czy Atharwaweda (Atharvaveda). Już w nich wyrażano wiarę w stwórczą moc języka, którego znajomość choćby z tego powodu była zakazana dla osób nieodpowiednich (por. Hymn o mowie RV X.15). 
szczególnym wykształceniem. Owe braki rekompensuje im jednak przebiegłość i złośliwość [...]. Konieczność zmusza ich do tego, żeby kłamać i ściągać od ludzi pieniądze, gdyż nie mają im nic lepszego do zaoferowania, oprócz tych kamiennych posągów [...]. Gdyby nie ta zdradliwa i godna pożałowania kasta, wszyscy mieszkańcy bez najmniejszego trudu staliby się chrześcijanami ${ }^{10}$.

Franciszek zaopatrzony w królewskie pełnomocnictwa oraz mandat legata papieskiego dotarł do Indii, a dokładnie na Goa, do stolicy Indii portugalskich w roku 1542 . Jego misją była przede wszystkim ewangelizacja. Realizował ją zarówno względem dorosłych, jak i dzieci, wygłaszał liczne kazania, spowiadał i odwiedzał ubogich i chorych. Założył też pierwszą siedzibę jezuitów w Azji, kolegium św. Pawła, którego celem było m.in. pozyskiwanie kapłanów spośród ludności miejscowej. Swoje działania rozszerzył na południowe Indie, docierając z czasem aż do Madrasu i Cejlonu " ${ }^{11}$. Franciszek za niektóre swoje działania był krytykowany. Starał się bowiem, by konwertyci przyjmowali europejski styl życia, np. nosili europejskie ubrania, przyjmowali za własne imiona portugalskie czy starali się niszczyć swoje świątynie. Jak pisze J. J. Higgingbotham w książce Men whom India has known: Biographies of eminent Indian characters, Xavier został wysłany do Indii n[...] aby zaszczepić wiarę katolicką w portugalskich posiadłościach w Azjin ${ }^{\text {12 }}$. Jego stosunek do miejscowych religii był niewątpliwie pełen

10 Fragmenty $z$ listu św. Franciszka Ksawerego podaję w tłumaczeniu Roksany Butryn, autorki artykułu: Bramini w liście Świętego Franciszka Ksawerego „Sociis Romae degentibus, Cocino 15 Ianuarii 1544”. "Studia Indologiczne" 2001 , vol. 8, s. $17-18$.

11 Franciszek był niewątpliwie wielkim podróżnikiem wędrującym po krajach szeroko pojętego Wschodu. Zmarł podczas próby dotarcia do Chin. $12 \mathrm{~J} . \mathrm{J}$. Higgin both a m, Men whom India has known. Biographies of eminent Indian characters, Madras 1874, s. 476 ("to plant the standard of the Romish 
pogardy. Mimo to został beatyfikowany w roku $1619 \mathrm{i}$ kanonizowany w roku 1622. W roku 1910 papież Pius X ogłosił go patronem Dzieła Rozkrzewiania Wiary. Z kolei w roku 1927 ogłoszono go głównym patronem misji katolickich.

Filippo Sassetti (1540-1588), włoski podróżnik i kupiec, który przebywał w Indiach w latach 1583-1588, dostarczył Europie jedne z pierwszych informacji na temat sanskrytu. Między innymi porównywał on słowa sanskryckie ze słowami łacińskimi i włoskimi ${ }^{13}$. Do Indii $w$ owym czasie przybywali $\mathrm{i}$ inni podróżnicy $\mathrm{i}$ kupcy, jednak w swoich opisach koncentrowali się na innych niż język szczegółach. Przede wszystkim dotyczyły one tego, co odmienne. W ramach tego opisywano np. dziwne zwyczaje ludności miejscowej. Jednym z przybyłych wtedy do Indii Europejczyków był polski podróżnik Krzysztof Pawłowski, który opisał swoje wrażenia w liście wysłanym w roku 1596. Jego uwagi dotyczyły głównie dziwnych owoców, warzyw i niespotykanych w Europie zwierząt ${ }^{14}$. Ponieważ wielu z braminów, wywodzących się ze słynnych bramińskich rodów, nie decydowało się na uczenie Europejczyków języka swoich świętych ksiąg, ci ostatni skoncentrowali się zatem na początku na językach lokalnych, w których mówiła współczesna im ludność miejscowa. Zaczęły zatem powstawać pisane przez Europejczyków gramatyki takich języków jak np. tamilski czy marathi. Bardzo szybko Europejczycy zorientowali się jednak, że do poznania kultury, religii czy obyczajów Indusów

faith in the Portuguese possessions of Asia"). Jeśli nie podano inaczej, to tłumaczenie i następne - Iwona Milewska.

13 Ta informacja została mi przekazana przez Klausa Kartunnena. Za tę $i$ inne uwagi do mojej pracy bardzo dziękuję.

14 S. Sta siak, Les Indes Portugaises à la fin du XVIe siècle d'après la Relation du voyage fait à Goa en 1596 par Christophe Pawłowski, gentilhomme polonais, „Rocznik Orientalistyczny" 1925, vol. 3, s. 1-56. 
niezbędne jest opanowanie sanskrytu jako jednego z głównych kluczy do zrozumienia Indii.

Pierwszymi misjonarzami, którzy dotarli do Indii już w pierwszej połowie XVI wieku, byli franciszkanie i dominikanie. Jednak to jezuici, którzy przybyli tam na przełomie XVI i XVII wieku, nie tylko zdali sobie sprawę, że dla krzewienia chrześcijaństwa niezbędna jest jak najlepsza znajomość języków lokalnych, ale też zaczęli zdecydowanie działać w tym kierunku. Jeden $z$ indyjskich konwertytów Manoel d'Oliveira przełożył na portugalski m.in. fragmenty marackiej parafrazy, jednej z najważniejszych indyjskich ksiąg świętych, Bhagawadgity (Bhagavadgītā) ${ }^{15}$. Jezuici byli tymi, których opisy gramatyki sanskrytu uważa się do tej pory za jedne z najwcześniejszych. Brytyjski jezuita Thomas Stephens (1549-1619), znany także jako Thomas Stevens, podczas swojego pobytu w Indiach nauczył się czytać i pisać w języku konkani oraz marathi. Stevens napisał po portugalsku wydaną w roku 1640 gramatykę języka konkani. Napisał też w mieszanym języku konkani i marackim dzieło Krista Purana, inaczej znane jako Chrześcijańska purana, poemat o życiu Chrystusa. Stevens przybył na Goa w roku 1579 i w liście do brata, datowanym na 24 października 1583 roku, wydanym w ramach serii Lettres édifiantes et curieuses, co można przetłumaczyć na język polski jako „Listy umoralniające i pełne dziwów"16, stwierdził podobieństwo zachodzące między językami Indii i Europy. Pisze on:

Bardzo wiele jest języków tych krain. Mowa ich nie jest bez wdzięku, a kompozycją podobna do łacińskiej i greckiej; zwroty i konstrukcje podziwu godne. Litery oznaczają sylaby i mają tyle różnych postaci,

15 W. Halbfass, op. cit., s. 75.

16 nListy..." wydawane były przez jezuitów i zawierały głównie opisy ich działalności misjonarskiej w Chinach, Indiach i w Ameryce Południowej. 
ile jest kombinacji spółgłosek z samogłoskami lub spółgłosek zwartych z płynnymi ${ }^{17}$.

Mimo iż to właśnie on jako pierwszy zasygnalizował europejskiej publiczności to podobieństwo, za osobę, która na nie wskazała, powszechnie uważa się Walijczyka Williama Jonesa. To właśnie on w swoim słynnym trzecim Anniversary Discourse, który wygłosił podczas spotkania odbywającego się w ramach zebrań Asiatic Society of Bengal 2 lutego 1786 roku, ogłosił, iż udało mu się zaobserwować podobieństwa między sanskrytem, greką, łaciną, niemieckim, językami celtyckimi i perskim:

Sanskryt, jakakolwiek byłaby jego starożytność, posiada wspaniałą strukturę; doskonalszy niż greka, bogatszy niż łacina, subtelniej wyrafinowany niż jedna i druga, ale pokrewny im obu; podobieństwo to wyraża się i w rdzeniach czasownikowych, i w określonych formach gramatycznych, nie mogąc być dziełem jedynie przypadku; pokrewieństwo jest tak duże, iż filolog nie może badać tej trójki bez wiary w ich wspólne pochodzenie ze źródła, które być może już nie istnieje. Podobny, choć nie tak wątpliwy powód sprawia, że można przypuszczać, iż również język gotycki i celtycki, mimo że nasycone innymi idiomami, mają wspólne $z$ sanskrytem pochodzenie; do tej

17 Za: J.-C. Muller, Recherches sur les premières grammaires manuscrites du Sanskrit, „Bulletin d'Études Indiennes” 1985, vol. 3, s. 125. W oryginale ten fragment jego listu brzmi następująco: „Linguae harum regionum sunt permultae. Pronunciationem habent non invenustam et compositione latinae grecaeque similem; phrases et constructiones plane mirabiles. Literae syllabarum vim habent, quae toties variantur quoties consonantes cum vocalibus, vel mutae cum liquidis combinari possunt". 
rodziny może być również dodany staroperski, jeśli tu właśnie byłoby miejsce na rozważanie pytań odnośnie do perskich starożytności ${ }^{18}$.

Mimo że wygłoszone ponad 200 lat później, to właśnie jego stwierdzenie stało się znane jako podstawa późniejszych badań w ramach językoznawstwa porównawczego.

Kolejną ważną postacią, o której nie sposób nie wspomnieć, gdy chce się opisać początki poznawania Indii przez Europejczyków w czasach nowożytnych, jest Ro-

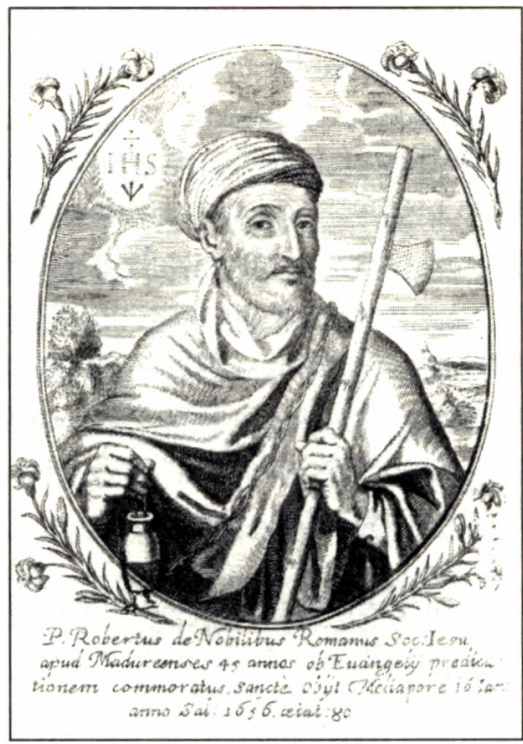

2. Roberto Nobili

18 Cytat ten podaję za: F. Edgerton, Sir William Jones, [w:] Portraits of Linguists: A Biographical Source Book for the History of Western Linguistics, 1746-1963, vol. 1: From Sir William Jones to Karl Brugmann, red. T. A. Sebeok, Bloomington-London 1966, s. 1-18. Pierwszy raz ten tekst został opublikowany w: Asiatic Researches, vol. 1, s. 442-443 ("The Sanskrit language, whatever be its antiquity, is of a wonderful structure; more perfect than the Greek, more copious than the Latin, and more exquisitely refined than either, yet bearing to both of them a stronger affinity, both in the roots of verbs and in the forms of grammar, than could possibly have been produced by accident; so strong indeed, that no philologist could examine them all three, without believing them to have sprung from some common source, which, perhaps, no longer exists; there is a similar reason, though not quite so forcible, for supposing that both Gothick and the Celtick, though blended with a very different idiom, had the same origin with the Sanskrit; and that old Persian might be added to the same family, if this were the place for discussing any question concerning the antiquities of Persia"). 
berto Nobili (1577-1656), uważany przez wielu za „ojca tamilskiej prozy". Ten urodzony w Montepulciano włoski jezuita przybył do Indii, a dokładnie na Goa, w roku 1605. Już w 1606 udał się do Maduraju w Tamilnadzie, aby tam właśnie nauczać. Po przybyciu na miejsce zamieszkał w dzielnicy indyjskiej, a dokładniej bramińskiej, uważał bowiem, iż podczas pobytu w Indiach należy przyjmować indyjski (w jego przeświadczeniu i wynikający z jego obserwacji) sposób zachowania się. Starał się zatem prowadzić życie podobne do indyjskiego sannjasina ${ }^{19}$. Ogolił głowę, pozostawiając tylko kosmyk włosów, nosił białe dhoti (tradycyjny strój indyjski) i drewniane sandały. Jak opisuje to Wilhelm Halbfass, Nobili uważał, że należy mówić lokalnymi językami, ubierać się jak Indusi, żyć na sposób indyjski. Zachowywać się, gdy tylko to możliwe, jak indyjski mędrzec ${ }^{20}$. Nobili uważał, że ta akceptacja powinna dotyczyć zarówno indyjskiego stylu życia, jak i sposobu myślenia. Powinna sprawiać, że chrześcijaństwo dostosowy wane jest do społecznych realiów w Indiach. Jak pisze Jan Kieniewicz w Historii Indii, Nobili „w sposób wyjątkowy pojmował, że należy obyczaj społeczny oddzielić od religii" ${ }^{\text {21 }}$. W jednej ze swoich prac pisał Nobili: „Chrześcijański kaznodzieja taki powinien obrać tryb życia, dzięki któremu zostanie uznany przez tych, między którymi przebywa, za godnego wysłuchania” i dalej przekonywał, że głosiciel Ewangelii powinien nastawić się na to „by odłożyć na bok obyczaje

19 Sannjasin (saṃnyāsin) wg słownika M. Moniera-Williamsa znaczy m.in. "one who abandons or resigns worldly affairs, an ascetic, devotee (who has resigned all earthly concerns and devotes himself to meditation and the study of the Āraṇyakas or Upanishads, a Brāhman in the fourth Āśrama or stage of his life, a religious mendicant", M. Monier-Willia ms, op. cit., s. 1148. 20 W. Halbfass, op. cit., s. 76-77.

${ }^{21} \mathrm{~J}$. Kieniewicz, Historia Indii, Wrocław-Warszawa-Kraków-Gdańsk 1980 , s. 453-454. 
swej ojczyzny i być Indusem wśród Indusów"22. Za swoje poglądy Nobili był ostro krytykowany w Europie, przede wszystkim przez swoich przełożonych. Krytykowali go także Portugalczycy w Indiach. Mimo tego właśnie on często jest nazywany pierwszym europejskim badaczem sanskrytu. Nobili pozostawił dwie książki, w których starał się opisać to, co, jego zdaniem, było ważne dla zrozumienia starożytnej kultury indyjskiej. Pierwsza z nich, zatytułowana Informatio de quibusdam moribus nationis indicae (Informacja o niektórych obyczajach ludu indyjskiego), została napisana w roku $1613^{23}$. Druga z kolei Narratio fundamentorum quibus Madurensis Missionis institutum caeptum est et hucusque consistit (Wykład o podstawach, na których wszczęto działalność Misji Madurajskiej i na których zasadza się ona do tej pory) powstawała w latach $1618-1619^{24}$. W tych pracach Nobili opisał m.in. tradycyjny indyjski podział na poszczególne dziedziny wiedzy. W Informatio..., w rozdziale 3, zatytułowanym De scientiis quas Brahmanes tractant (O naukach, które uprawiają bramini), pisał o naukach, których twórcami i tymi, którzy je opisali, byli bramini. Pośród nich jako pierwszą wymienił gramatykę Siabda Siastram (śabda-śāstra). Pisał dalej m.in. też o poetyce Cavviam (kāvya). Można

22 "Evangelicus concionatur illam instituere debet vivendi rationem, qua dignus iudicetur $a b$ iis, inter quos versatur; qui audiatur ${ }^{n}{ }$ $p$ patrios abnegare mores, et inter Indos Indum essen. Za W. Halbfass, op. cit., s. 81.

23 Stała się szerzej znana w Europie, kiedy została wydana ponownie. Nastąpiło to dopiero w wieku XX. Por. On Indian Custom, przeł. S. Rajamanickam, Palayamkottai 1972.

24 Podobnie druga $z$ nich została wydana i przetłumaczona $w$ XX wieku przez J. Pujo. Jej tytuł brzmiał Adaptation i została wydana w Palayamkottai w 1971 roku. Warto wspomnieć, że większość jego pism jeszcze do niedawna uważano za zaginione, tymczasem niektóre $\mathbf{z}$ nich ukazały się już wcześniej czy to po tamilsku, czy po łacinie. 
również znaleźć tutaj, w rozdziale 4, kilka cytatów w sanskrycie ${ }^{25}$. Z kolei w Narratio... przedstawił w pełniejszej formie swoje założenia odnośnie do pracy misyjnej. Uważał, że podstawą jest przyswojenie języków miejscowych, a i to jest niewystarczające ${ }^{26}$. Christopher Vielle

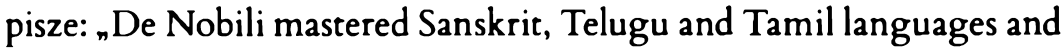
literature, with the help of his teacher, Shivadharma" ${ }_{n}$ De Nobili znał język i literaturę tamilskiego, telugu i sanskrytu. Jego nauczycielem był indyjski uczony bramin Śiwadharma (Śivadharma)"] ${ }^{27}$. Miał wielu uczniów pochodzących przede wszystkim z wyższych warstw społeczeństwa indyjskiego. Udało mu się osiągnąć taki efekt niewątpliwie ze względu na to, iż umiał głosić Ewangelię w sposób dostosowany do standardów indyjskich. Zrozumiał także, iż w Indiach niezwykle ważna jest umiejętność prowadzenia życia w sposób ascetyczny, że doktryna może być przyjęta od osoby, której udało się zdobyć poważanie w ramach systemu indyjskich, a niekoniecznie europejskich wartości. Odnosił się do Indusów z pełnym uszanowaniem, a braminów nazywał mędrcami czy uczonymi. Starał się być ${ }_{n}$ Hindusem pomiędzy Hindusami ${ }^{\text {228. }}$.

25 Dokładniejszy opis zawartości Informatio... patrz: W. Halbfass, op. cit., s. 78-81.

26 B. Griffiths w książce Złota nić, pisząc o Roberto Nobilim, stwierdza, iż istotnie przyjął on sposób życia indyjskiego mędrca (sannjasina), a pamięć o tym przetrwała. To dopiero pozwoliło mu nawiązać kontakt z wyższą warstwą społeczeństwa indyjskiego (B. Griffiths, Złota nić. Chrześcijański aśram, przeł. J. Mroczkowska, Kraków 1974, s. 218-219).

27 Por. Grammatica Grandonica: The Sanskrit Grammar of Johann Ernst Hanxleden S.J. (1681-1732), red. Ch. Vielle, T. Van Hal, Potsdam 2013, s. 211. ${ }^{28}$ Jego idee, jakkolwiek służyły innym celom, są podobne do niektórych $z$ metod stosowanych także współcześnie w uczeniu się i nauczaniu języków nazywanych njęzykami obcymi". Bardzo podobne są bowiem do zaleceń kulturoznawstwa, uważanego obecnie za czynnik, który powinien nieodłącznie towarzyszyć nauczaniu jakiegokolwiek nieznanego języka. 
Jego działalność spotkała się nie tylko z krytyką, ale także z próbami przeciwdziałania jej. Krytykowali go zarówno Portugalczycy w Indiach, jak i Watykan. Przebywający w Indiach misjonarze, wywodzący się czy to z zakonu jezuitów, czy franciszkanów, potępiali go i starali się uniemożliwić jego wpływ na indyjskie elity. Nobili akceptował indyjski podział społeczeństwa na określone warstwy i kasty. Nie starał się przystosować tej cechy do zasad europejskich. Jego sposób myślenia o tych sprawach został zaakceptowany dopiero przez papieża Grzegorza XV w roku 1623. Praca misyjna Nobilego trwała około 40 lat. Uważa się, że w tym czasie udało mu się nawrócić około 100000 Indusów pochodzących ze wszystkich kast ${ }^{29}$. Jest niewątpliwe, że tym, co pozostawił po sobie, byli nie tylko jego liczni uczniowie, ale także Europejczycy, którzy dzięki niemu tak właśnie zaczęli myśleć o indyjskich wartościach i uwarunkowaniach społecznych. $\mathrm{Na}$ koniec warto jednak dodać, że postawa licznych europejskich misjonarzy, przeciwników metod działania Nobilego, sprawiała, iż wielu indyjskich braminów miało argumenty na rzecz przeciwstawiania się rozpowszechnianiu chrześcijaństwa w Indiach. Roberto Nobili był atakowany przez braminów obawiających się jego wpływu na miejscową ludność. Po raz w tóry dawały o sobie znać trudności właściwe obu stronom mających spotykać się, przynajmniej w wymiarze kulturowym, Indusów i Europejczyków. Nobili wierzył jednak, iż możliwe jest głębokie spotkanie o charakterze międzykulturowym. Dał temu wyraz m.in. jako inicjator tradycji debat przeprowadzanych między kapłanami indyjskimi a misjonarzami ${ }^{30}$.

Byli jeszcze inni europejscy misjonarze, którzy udali się do Indii w tym czasie w celu ewangelizacji. Jednym z nich był Portugalczyk John Britto, który sam nadał sobie indyjskie imię Arul Anandar (1647- 
1693). W roku 1673 dotarł on do misji w Maduraju, gdzie poza pracą kapłańską oddał się poznawaniu miejscowych języków i ich literatur. Szczególnie interesował się językiem marathi. Kolejną osobą był włoski jezuita Constantine Joseph Beschi znany jako Wiramamuniwar (Vīramāmunivar) (1680-1742). Jego specjalnością stał się język tamilski, o którym pisał, a nawet stworzył w tym języku długi poemat ${ }^{31}$. $\mathrm{Z}$ pewnością świadczy to o jego dużej kompetencji językowej i umiejętności przyswajania języka w stopniu zdumiewającym. W roku 1710 dotarł na Goa, by wkrótce udać się do misji w Maduraju. Jest także autorem licznych dzieł o charakterze gramatycznym. Beschi przebywał w Indiach ponad 30 lat, spędzając czas głównie w towarzystwie Indusów.

31 Poemat ten składa się z 3615 strof i dotyczy życia św. Józefa. 



\section{Część II}

\section{Łacińskie gramatyki sanskrytu - XVII i XVIII wiek}





\section{Heinrich Roth, Grammatica linguae Sanscretane Brahmanum Indiae Orientalis}

Zgodnie z obecnym stanem badań za pierwszego Europejczyka, który w sposób uporządkowany i szczegółowy opisał gramatykę sanskrytu, uważa się niemieckiego jezuitę, misjonarza Heinricha Rotha (1620-

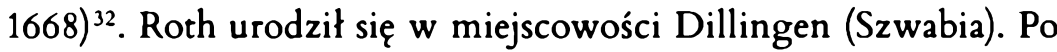
studiach w Dillingen i Insbrucku w roku 1639 wstąpił do zakonu jezuitów. Spędził w Indiach, przede wszystkim na Goa i w Agrze, około 10 lat. $\mathrm{Na}$ Goa dotarł drogą lądową przez Smyrnę, Isfahan, Ormuz i Surat w roku 1652, skąd w roku 1654 został wysłany do kolegium jezuickiego w Agrze. W Indiach panował wówczas władca z dynastii Mogołów, cesarz Szahdżahan, a później jego syn padyszach Aurangzeb. Roth, jako osoba uzdolniona językowo bardzo szybko nauczył się kilku języków m.in. języka dworu, czyli języka perskiego. Pracował także, od czasu do czasu, jako tłumacz języka portugalskiego. Wkrótce zorientował się, że językiem wyższych warstw społeczeństwa indyjskiego jest sanskryt, dlatego bardzo szybko rozpoczął naukę tego języka indyjskich świętych ksiąg. Trwała ona około sześciu lat ${ }^{33}$. Nauki pobierał od bramina o nieznanym imieniu. Najprawdopodobniej działo się to pomiędzy rokiem 1654 a $1660^{34}$. Swoją działalność prowadził

32 Heinrich Roth znany jest także jako Henricus Rodius albo Henrique Roa.

33 A. Camps, Father Heinrich Roth, S.J. and the History of his Sanskrit Manuscripts by Arnulf Camps, O.F.M., [w:] The Sanskrit Grammar and Manuscripts of Father Heinrich Roth S.J. (1620-1668), Leiden-New York-København-Köln 1988 , s. 186-187.

3 Ibidem, s. 191. 
w sposób podobny do sposobu Roberto Nobilego. Podobnie jak tego drugiego ciekawiło go wiele dziedzin. Między innymi interesował się indyjską literaturą i filozofią. Był niewątpliwie uzdolniony językowo. Wiedzę zdobywał u lokalnych panditów, oczywiście tylko tych, którzy chcieli się nią dzielić z Europejczykami. W roku 1659 Roth został mianowany rektorem kolegium. Wiadomo, że podczas swego pobytu w Indiach praktykował medycynę, zarówno na dworze, jak i wśród ludności miejscowej ${ }^{35}$.

Roth swoją gramatykę zatytułowaną Grammatica linguae Sanscretanae Brachmanum Indiae Orientalis (Gramatyka języka sanskryckiego braminów Indii Wschodnich) pisał najprawdopodobniej w latach 1660-1662. Przywiózł ją do Europy, do Rzymu, w roku $1664^{36}$. Jest to gramatyka, w której zagadnienia gramatyczne zostały opisane po łacinie, przykłady form podawane przez Rotha są przede wszystkim w alfabecie dewanagari (devanāgarī) ${ }^{37}$, ale także niektóre $z$ form podaje w języku i alfabecie malajalam. Roth uczył się sanskrytu około sześciu lat, korzystając z pomocy lokalnych, bezimiennych panditów. Gramatyka Rotha to gramatyka opisowa - poszczególne zagadnienia omawiane są szczegółowo w kolejności właściwej dla wyróżnianych krok po kroku form gramatycznych. Niestety praca Rotha przez wiele lat, czy nawet wieków, pozostała jedynie w formie manuskryptu. Nie została udostępniona czytelnikom europejskim w formie drukowanej, mimo że do Europy dotarła już pomiędzy rokiem 1664

$35 \quad$ Ibidem, s. 187.

36 Pierwsza wzmianka dotycząca tej gramatyki znajduje się w raporcie, który Roth sporządził w Rzymie dla Johannesa Paulusa Olivy, który był w tym czasie Generałem Towarzystwa Jezusowego (A. Camps, op. cit., s. 191).

37 Dewanagari wg słownika $M$. Moniera-Williamsa znaczy „divine city writing; name of the character in which Sanskrit is usually written (prob. from its having originated in some city)", M. Monier-Williams, op. cit., s. 493. 


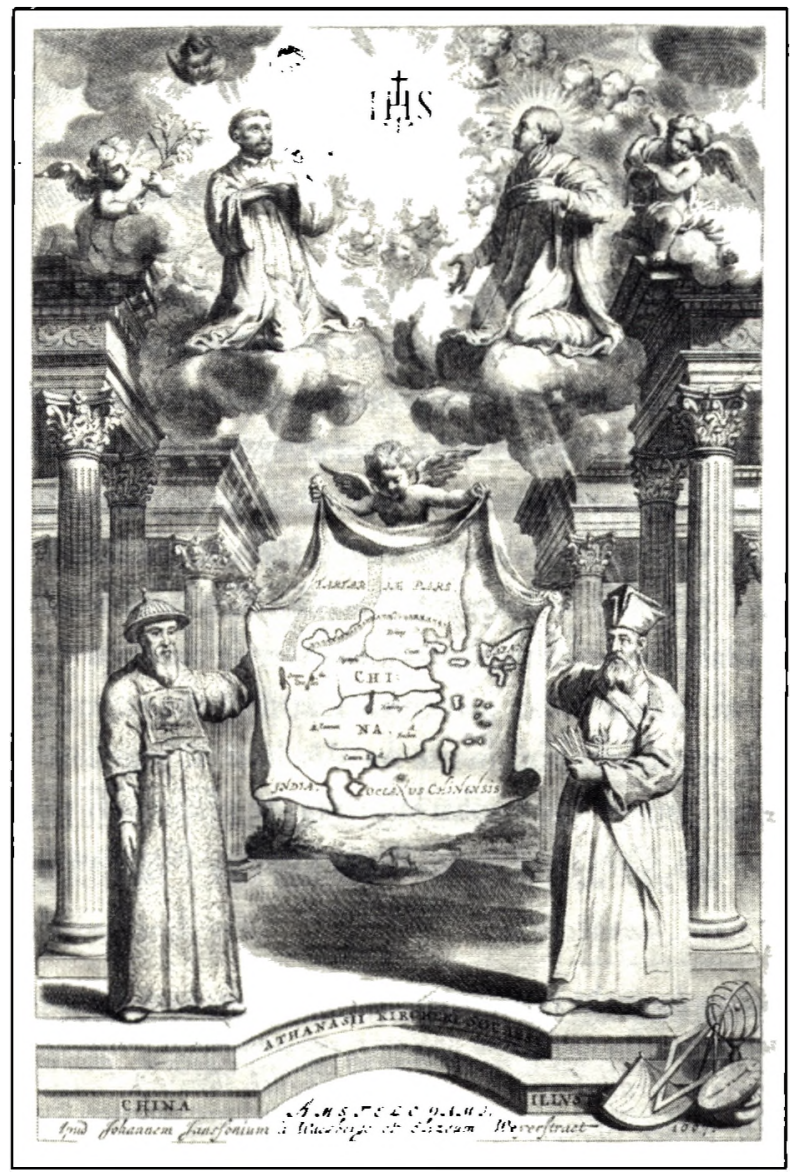

3. Athanasius Kircher, China Illustrata, frontispis

a 1665. Przypuszcza się nawet, że był to zabieg celowy dokonany przez przełożonych Rotha. Zależało im bowiem na tym, by wiedza o odległych lądach wraz $z$ ich odmiennymi od chrześcijaństwa religiami nie przedostawała się możliwie długo do Europy. Niewykluczone jednak, że gramatyka Rotha nie została wydrukowana po prostu z powodu trudności technicznych. 
Osobą, która była zainteresowana pracą Rotha, był jeden z jezuitów, Niemiec Athanasius Kircher (1602-1680), znawca kultur i języków orientalnych. Poza Chinami również Indie były w obszarze jego zainteresowania. Kircher wydał w 1667 roku w Amsterdamie książkę China Illustrata ${ }^{38}$.

Jeden z jej rozdziałów, zatytułowany Decem fabulosae Incarnationes Dei, quas credunt gentiles Indiani extra et intra Gangem ex interpretatione $P$. Henrici Roth, jest po części fragmentem pracy Rotha. Ponieważ ten ostatni przebywał w Rzymie tylko dwa miesiące, Kircherowi udało się w swojej książce zamieścić jedynie pięć tablic zawierających sanskrycki alfabet i jego krótką charakterystykę ${ }^{39}$. Była to pierwsza publikacja pisma nagari (nāgarī) w Europie. Książka Kirchera zawierała także zapisaną w alfabecie dewanagari łacińską wersję modlitwy Pater Noster.

Roth, tym razem wraz $z$ innym jezuitą Johannem Grueberem (1623-1680), wyruszył ponownie na Wschód. Z jego listu wysłanego z Wenecji 7 maja 1664 roku wynika, iż planowali podróż przez Niemcy, Austrię, Czechy, Polskę, Rosję i Persję. Najprawdopodobniej

38 Oryginalny, łaciński tytuł dzieła brzmiał Athanasii Kircheri e Soc. Jesu China monumentis, qua sacris qua profanis, nec non variis Naturae et artis spectaculis, aliarumque rerum memorabilium argumentis illustrata, auspiciis Leopoldi primi, Roman. Imper. Semper Augusti Munificentissimi Mecaenatis. Książka zawierała ogromną ilość informacji dotyczących przede wszystkim Chin. Bardzo szybko, bo już w roku 1668, została przetłumaczona na język holenderski, a w roku 1670 na język angielski. Stała się zatem dostępna relatywnie szerokim kręgom odbiorców europejskich. Książka przez niektórych była krytykowana jako nie naukowa, lecz raczej "rozrywkowa" (tak twierdzili m.in. Gottfried Leibniz czy Adolf Erman). Jest jednak poświadczone, że Kircher korzystał podczas jej opracowywania $z$ wiadomości pochodzących od misjonarzy z zakonu jezuitów, a jednym $z$ jego informatorów był Heinrich Roth.

39 Ciekawostką jest, że Roth osobiście przygotował stosowne czcionki (A. Camps, op. cit., s. 189). 


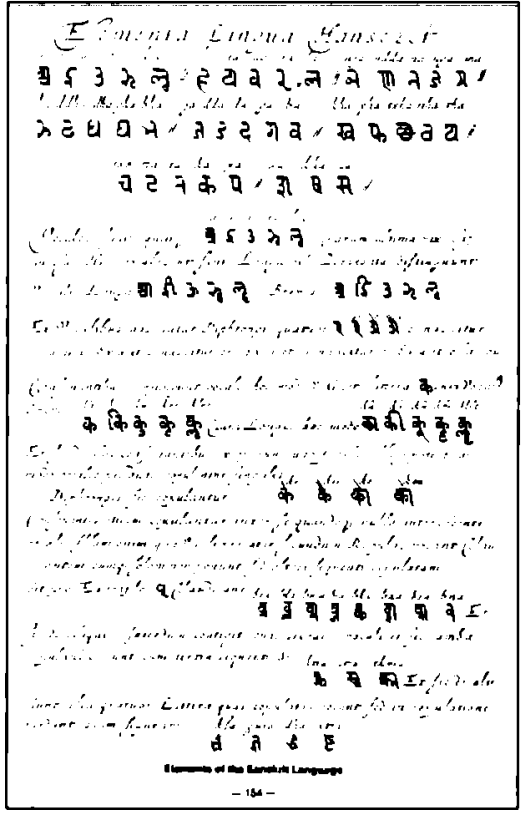

4. Athanasius Kircher, China Illustrata, alfabet sanskrycki

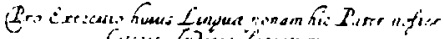

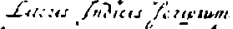

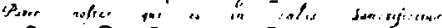

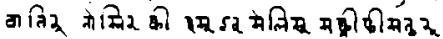

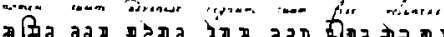

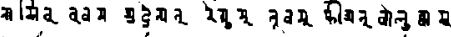

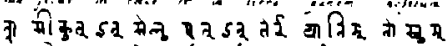

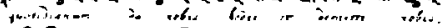

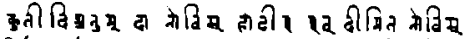

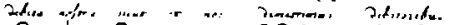



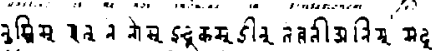
is.. $\cdots$ :

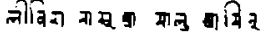

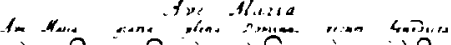

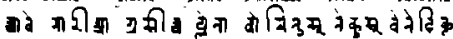

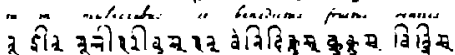
"'

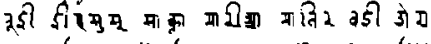

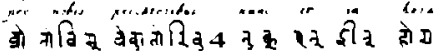

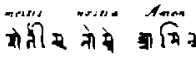

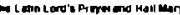
thitum in Genatura Lerions - 1 s.

5. Athanasius Kircher, China Illustrata, modlitwa ${ }_{n}$ Pater Noster ${ }^{n}$

dotarli do Gdańska, ale zorientowawszy się, że podróż przez Rosję jest niemożliwa, podjęli próbę przedostania się dalej przez Turcję. To właśnie tam Grueber zachorował i postanowili się rozstać. W pośpiechu pomylono bagaże i gramatyka Rotha powędrowała wraz z Grueberem z powrotem do Rzymu. Roth ponownie dotarł do Indii, do Suratu, w roku 1666, by następnie udać się do Agry i podjąć próbę wyprawy do Nepalu. To właśnie w jej trakcie zachorował $\mathrm{i}$ był zmuszony do powrotu do Agry. Tam zmarł 20 czerwca 1668 roku $^{40}$. Sam manuskrypt gramatyki ostatni raz był widziany przez słynnego lingwistę, jezuitę, ojca Lorenzo Hervása y Panduro (1735-1809). Było to w roku 1800, 
w bibliotece Collegio Romano ${ }^{41}$. Zbiory tej biblioteki zostały potem włączone do zasobów Biblioteca Nazionale w Rzymie. Osobą, która starała się przez wiele lat odnaleźć tę gramatykę, był Theodor Zachariae. Niestety jego usiłowania nie zakończyły się sukcesem. Podobnie jak późniejsi badacze, Sebastian Euringer i jezuita F. Joseph Linder, także i poszukujący jej Richard Hauschild musiał w roku 1956 przyznać, że gramatyka Rotha zniknęła bez śladu ${ }^{42}$. Bardzo szeroko zakrojone poszukiwania w tym samym 1956 roku przeprowadził też Bruno Zimmel. Stwierdził on, że nie sposób jej odnaleźć ani w Biblioteca Nazionale, ani w Museo Nazionale Preistorico Etnografico „Luigi Pigorini”, ani w rzymskich archiwach Towarzystwa Jezusowego, ani w archiwach Uniwersytetu Gregoriańskiego, ani w archiwach watykańskich, ani w Bibliotece Watykańskiej ${ }^{43}$.

Ostatecznie gramatyka została jednak szczęśliwie odnaleziona. Stało się to dopiero w roku 1967. Wtedy to właśnie została odszukana przez Arnulfa Campsa. Podczas kwerendy w Biblioteca Nazionale w Rzymie Camps został poinformowany o istnieniu katalogu orientalnych manuskryptów. Przeglądając ten katalog (Inventario Orientali), Camps natknął się na dwa manuskrypty (Mss Orientali 171 i 172). Jeden z nich był zatytułowany Grammatica linguae sanscretane Brahmanum Indiae Orientalis, drugi zaś zawierał sanskrycki tekst z zapisanymi na marginesach i pomiędzy wersami uwagami po łacinie ${ }^{44}$. Manuskrypt 171 to właśnie poszukiwana bezskutecznie od stuleci gramatyka autorstwa Heinricha Rotha.

Po około 20 latach starań gramatyka została opublikowana dopiero w roku 1988. Wstęp oraz przygotowanie manuskryptu do druku zo-

41 Por. ibidem, s. 1 (Wstęp), 193.

42 Ibidem, s. 193-194.

43 Ibidem, s. 194.

44 Jako że uwagi te zapisane zostały ręką Rotha, także i ten manuskrypt musiał pochodzić z XVII wieku. 
stało dokonane przez Arnulfa Campsa i Jeana-Claude’a Mullera. Praca zatytułowana The Sanskrit Grammar and Manuscript of Father Heinrich Roth S.J. (1620-1668) zawierała tekst samej gramatyki Grammatica linguae Sanscretane Brachmanum Indiae Orientalis, 1660-1662 $\mathrm{w}$ postaci faksymile dwóch manuskryptów pochodzących z Biblioteca Nazionale w Rzymie ${ }^{45}$ oraz wspomniany już wstęp i została wydana w Leiden.

Gramatyka Rotha składa się z pięciu głównych rozdziałów. Są to kolejno: De Ortographia, De Declinationibus Nominum, De Coniugationibus Verborum, De Verbalibus seu krdamtah oraz De syntaxi huius Linguae. Gramatyka zawiera też krótki Appendix ad universam grammaticam ${ }^{46}$. Tekst zapisany w średniowiecznej łacinie jest czytelny i zaopatrzony w przykłady w alfabecie nagari (nāgari) czy dewanagari (devanāgarī). Roth relatywnie często używa w nim skrótów. Używa także, znanej mu niewątpliwie, indyjskiej terminologii gramatycznej.

W rozdziale 1 tej gramatyki (De Ortographia) opisano samogłoski akszara (akṣara) i występujące niezależnie spółgłoski warna (varṇa). Podano także ich transliterację. Jest tych znaków 38. Zostały podzielone na grupy. Sam schemat, w którym Roth je podaje, odbiega od obowiązującego w wielu opisach obecnie. Grupy są następujące: 5 półsamogłosek (h, y, v, r, l), nosowe (n, n, ń, n, m), dźwięczne przydechowe (jh, dh, ḍh, gh, bh), dźwięczne (j, ḍ, d, g, b), bezdźwięczne przydechowe (kh, ph, ch, țh, th), bezdźwięczne (c, ț, t, k, p) i spiranty (s,s ș, s). Tym, co uderza, jest pozycja półsamogłosek, które umiejscowione są pomiędzy samogłoskami i spółgłoskami. Następnie są wymienione

t5 MSS.OR. 171 i 172.

46 Zawartość gramatyki Rotha opisuje szczegółowo m.in. J.-C. Muller, op. cit., s. 125-144; R. Hauschild, Zum Inhalt der Drei Handschriften Roths, [w:] Zeitschrift für Missionswissenschaft und Religionswissenschaft, Münster 1969, vol. 53, s. 195-202; idem, Notes on the Content of the Three Manuscripts of Heinrich Roth (translated into English and revised by Jean-Claude Muller), [w:] The Sanskrit Grammar and Manuscripts of father Heinrich Roth S.J., s. 13-19. 
nosówki i grupy wymienione ze względu na ich dźwięczność i przydechowość. W dalszej części przedstawiono najczęściej występujące ligatury ${ }^{47}$ oraz reguły zewnętrznego i wewnętrznego sandhi (De Concurrencia et Mutacione Litterarum) ${ }^{48}$. Tutaj Roth wspomina także o zjawisku cerebralizacji, o wisardze (visarga), anuswarze (anusvāra) i wiramie (virāma). Reguły sandhi zostały zaopatrzone w ilustrujące je przykłady. W osobnym podrozdziale Roth skupia się na różnych rodzajach samogłosek [nazywając je krótkimi, hraswa (hrasva), długimi, dirgha (dīrgha) lub pluta] oraz na opisie dyftongów. Pisze też o stopniowaniu samogłosek i o zjawisku samprasarany (samprasāraṇa), a następnie wspomina krótko o akcentach wedyjskich udatta (udātta), anudatta (anudātta) i swarita (svarita). Rozdział kończy się podaniem definicji wybranych form terminologii gramatycznej używanej w opisie sanskrytu dokonywanym przez jego indyjskich znawców, których używa w dalszej części swej prezentacji gramatyki sanskrytu.

Rozdział 2 (De Declinacionibus Nominum) został poświęcony opisowi i podaniu paradygmatów odmian rzeczowników, przymiotników i zaimków. Poszczególne paradygmaty uporządkowano ze względu na samogłoskowe zakończenia tematów (podano 10 paradygmatów uporządkowanych w ramach 6 grup) lub ich zakończenia spółgłoskowe (13). Warto zauważyć, że zaproponowany podział bardzo przypomina ten stosowany w większości gramatyk sanskrytu do tej pory. Można tu znaleźć także ogólne informacje dotyczące rodzajów, przypadków, odmiany i liczb. W dalszej części zawarto listę możliwych końcówek poszczególnych przypadków. Roth podaje paradygmaty poszczególnych przykładów w następującym porządku:

47 Ligatura to sposób zapisu połączenia bezpośrednio występujących po sobie spółgłosek.

48 Sandhi to wzajemne oddziaływanie występujących bezpośrednio obok siebie głosek. 
1. masculina i neutra kończące się na -a (deva, kula),

2. masculina i feminina kończące się na -ā (somapā, gañgā),

3. m, f, n kończące się na -i, -u (hari, sakhi, buddhi, bhānu, dhenu, asthi, madhu),

4. $\mathrm{m}$, f kończące się na -ī, -ū, jedno- i wielosylabowe (suśrū, nadī, svayambhū, bhrū),

5. $\mathrm{m}, \mathrm{f}, \mathrm{n}$ kończące się na -ṛ (pitr, kartṛ),

6. m, f, n kończące się na -e, -o, -ai, -au (surai, go, glau).

Podział ten jest jasny i mający swe uzasadnienie $w$ analogiczności określonych form przypadkowych ${ }^{49}$. W części zatytułowanej Declinaciones hasamta seu Terminatorum in Consonantem przedstawiona jest deklinacja spółgłoskowa zilustrowana następującymi przykładami:

1. madhulih,

2. gir,

3. samrāj,

4. rājan,

5. tatvaprāch,

6. agnimath,

7. tatvabudh,

8. viś,

9. doṣ,

10. pratyac,

11. div, kakubh, ap,

12. marut, mahat, bhavat, jagat,

13. pums.

Podane są również wyjątki. Przedstawienie deklinacji spółgłoskowej należy do trudnych zagadnień. Późniejsi autorzy tych przedstawień proponują wciąż nowe rozwiązania. Propozycja Rotha jest wystarcza-

49 Sam podział bywa w późniejszej europejskiej tradycji modyfikowany, ale idea pozostaje niezmieniona. 
jąco obszerna, by opisać to, co jest charakterystyczną cechą deklinacji spółgłoskowej, a mianowicie zmiany w niektórych tematach. Brakuje jednak przykładu na trójtematowość. Budzi też zastrzeżenia umieszczenie w jednej grupie jednotematowych (marut, jagat) $z$ dwutematowymi (mahat, bhavat). Kolejna część (De Pronominibus) dotyczy zaimków. W przedstawieniu zawarto $10 \mathrm{z}$ nich. Są to kolejno:

1. twad (tvad), juszmad (yuṣmad),

2. mad (mad), asmad (asmad),

3. tjad (tyad),

4. $\operatorname{tad}(\mathrm{tad})$,

5. jad (yad),

6. kim (kim),

7. etad (etad),

8. idam (idam),

9. adas (adas),

10. swah (svah).

Następnie przedstawiono derywaty zaimkowe typu tawaka (tāvaka), mamaka (māmaka), zaimki posesywne, pytające, nieokreślone itd. Przegląd ten trzeba uznać za dobre wprowadzenie w dziedzinę zaimków sanskryckich. Podano także opis liczebników (Numeralia) głównych i porządkowych. Na zakończenie Roth omawia wybrane reguły ich derywacji ${ }^{50}$.

W rozdziale 3 (De Coniugationibus Verborum) Roth omówił obszerny temat czasowników. Przede wszystkim poświęcił uwagę rdzeniom czasownikowym. Omówił także formy parasmaipadam (parasmaipadam) i atmanepadam (ātmanepadam), właściwe poszczególnym rdzeniom. Wspomniał ogólnie o pierwiastkach setowych (seț) i anitowych (aniț). Opisał reguły ogólne dotyczące czasów, trybów, końcówek (w tym

so Np. sufiksy $-\bar{a},-\bar{i},-\bar{u}$ tworzące feminina i sufiksy typu taddhita (taddhita) służące tworzeniu patronimików czy form posesywnych. 
również końcówek perfectum, trybu życzącego, futurum opisowego i aorystu). Podał tradycyjny indyjski podział na 10 klas czasowników, zaopatrując ten fragment typowymi przykładami ${ }^{51}$. Podana jest dla każdej z nich odmiana w trzech trybach: indicativie, optativie, imperativie oraz odmiana w czasie imperfectum. Przykłady rdzeni odmienianych w ramach tych 10 klas są następujące:

klasa I bhū

klasa II ad

klasa III hu

klasa IV div

klasa V su

klasa VI rudh

klasa VII tan

klasa VIII tud

klasa IX krī

klasa X cur ${ }^{52}$.

Roth pisze także o wyjątkach. Tutaj omawia także, nadając mu łacińską nazwę, praeteritum. Omówieniu systemu czasownikowego, trybów oraz podaniu charakterystycznych końcówek i ilustrujących te zagadnienia paradygmatów poświęca Roth kolejną część. Poszczególne przykłady czasowników przynależących do określonych klas podaje w trybie oznajmującym (indicativus), przypuszczającym (optativus), rozkazującym (imperativus) oraz w jednym z czasów przeszłych określonym przez niego terminem imperfectum. W kolejnym fragmencie rozdziału 3 omawia formy bezosobowe i stronę bierną (passivum).

51 Należy podkreślić, że Roth podawał paradygmaty we właściwy tradycji indyjskiej sposób, czyli rozpoczynając od 3 osoby liczby pojedynczej.

52 Mimo że porządek częściowo różni się od przyjmowanego obecnie, warto zwrócić uwagę, że wiele z przykładów się powtarza. W szczególności klasy I, III, IV, V, IX i X ilustruje się najczęściej tymi samymi przykładami i w późniejszej tradycji europejskich opisów gramatyki sanskrytu. 
Dalej w podrozdziale zatytułowanym De Verbis Derivatis przedstawia informacje dotyczące intensivum, imitativum, desiderativum i causativum. $\mathrm{Na}$ zakończenie podaje listę form, które zostały opisane jako nietypowe Anomalia.

W rozdziale 4 (De Verbalibus seu krdamita) Roth zebrał informacje dotyczące rzeczowników odsłownych (kṛdamta), form imiennych czasownika, czyli participiów, bezokoliczników (infinitivus) i gerundiów. Zaopatrzył go także w kilka opisów form niemieszczących się we wcześniej omówionych kategoriach (Varia Verbalia).

Rozdział 5 (De syntaxi huius linguae) dotyczy przede wszystkim składni. Zawiera także apendyks poświęcony adverbiom. Opisano w nim funkcje przypadków, przy czym nie zalicza się do nich wołacza, oraz system złożeń. Roth rozróżnia sześć rodzajów złożeń. Są to złożenia typu awjajibhawa (avyayībhāva), tatpurusza (tatpuruṣa), dwandwa (dvandva), karmadharaja (karmadhāraya), dwigu (dvigu) i bahuwrihi (bahuvrīhi). Przedstawia je w tej właśnie kolejności. Podział ten tym różni się od stosowanego powszechnie później, że wydziela dopiero pod koniec złożenia typu karmadharaja i dwigu, podczas gdy zwykle są one przedstawiane jako rodzaje tych określanych jako tatpurusza. W dalszej części pisze o formach nieodmiennych, pośród których wyróżnia prepozycje, przysłówki, wykrzykniki i spójniki.

Appendyks pierwszy (Appendix ad universam grammaticam), w który zaopatrzona jest gramatyka, zawiera informacje dotyczące 37 rodzajów strof zapisywanych metrycznie. Podane są dla każdej z nich przykłady oraz łacińskie tłumaczenie ich nazw. Najprawdopodobniej podstawą tego appendyksu był tekst Śrutabodha (Śrutabodha) poświęcony metryce, który tradycja przypisuje Kalidasie (Kālidāsa). Apendyks drugi to z kolei dwa manuskrypty Pańczatattwaprakaśa (Pańcatattvaprakāśa), słownik synonimów autorstwa Wenidatty (Veṇiidatta) i Wedantasara (Vedāntasāra) Sadanandy (Sadānanda), wprowadzenie w filozofię wedanty. Wiadomo, iż tekst pierwszego manuskryptu został zapisa- 
ny dopiero w roku 1644. Rozpoczyna się on tradycyjnie stosowaną w wielu tekstach sanskryckich inwokacją do boga Ganeśi ${ }^{53}$.

Roth używał w opisie poszczególnych zagadnień gramatycznych indyjskiej terminologii gramatycznej. Między innymi to właśnie stosowanie określonej terminologii wskazuje, iż indyjski nauczyciel Rotha musiał mu przekazywać wiedzę pochodzącą z popularnej w owych czasach na terenach Hindustanu, Biharu i w Benares gramatyki Saraswata Wjakarana (Sārasvata Vyākaraṇa) autorstwa Anubhutiego Swarupaczarii (Anubhūti Svarūpācārya) ${ }^{54}$. Jest to bardzo prawdopodobne także dlatego, że Roth pobierał nauki i pisał tę gramatykę w Agrze. Mniej oczywiste jest, iż używał gramatyki zatytułowanej Mugdhabodha (Mugdhabodha), której autorem był żyjący w XIII wieku Wopadewa (Vopadeva) ${ }^{55}$. Ta ostatnia cieszyła się dużą popularnością w Bengalu, czyli na terenach odległych od miejsca przebywania Rotha. Saraswata Wjakarana jest zapisana w 1494 sutrach (sūtra), czyli bardzo skrótowych formułach używanych w wielu tekstach indyjskich. Celem takiego zapisu było ułatwienie zapamiętywania tekstów ${ }^{56}$. Jak wspomniano wyżej gramatyka Swarupaczarii była w tym okresie bardzo popularna. Jej rozpowszechnianie wspierali tak książęta, wyznawcy hinduizmu, jak i ci, dla których najważniejszą religią był islam. Ponieważ Mugdhabodha, mimo że powstała w Bengalu, jest jednak prawdopodobnym

53 Jedno z podań głosi, że gramatyka ta została objawiona bogini Saraswati (Sarasvatī). Szczegółowo pisze o tej gramatyce i o jej potencjalnych źródłach: H. Scharfe, Grammatical Literature, [w:] A History of Sanskrit Literature, vol. 5, part 2, red. J. Gonda, Wiesbaden 1977, s. 189-190.

54 Więcej informacji na temat tej gramatyki por. ibidem.

55 Więcej informacji por. ibidem, s. 188-189.

so Sutra (sūtra) to wg M. Moniera-Williamsa m.in. na thread, yarn, string, line, cord, wire; a sort sentence or aphoristic rule, and any work or manual consisting of stings of such rules hanging together like threads", M. Monier-Willia ms, op. cit., s. 1241. 
źródłem wiedzy Rotha, warto dodać kilka słów na także na temat jej autora i samej gramatyki ${ }^{57}$. Wopadewa mieszkał w Maharasztrze, a jego rodzina pozostawała w służbie królów Jadawy (Yādava). Jego gramatyka składała się z 1184 reguł typu sutrowego, podzielonych na 26 rozdziałów. Jest niewątpliwie dziełem, którego celem jest jak największa skrótowość, a zarazem prostota przedstawienia materiału gramatycznego $^{58}$.

Gramatyka Rotha, jak na czas, kiedy została napisana, oraz jej niewątpliwe nowatorstwo, jest w dużej mierze adekwatna, a na pewno bardzo wyczerpująca. Jej konstrukcja jest bardzo przejrzysta. Trudno oprzeć się uczuciu podziwu dla kompletności wykładu Rotha. Nie dziwi, że wiele z późniejszych gramatyk pisanych przez Europejczyków opiera się na podobnym schemacie przedstawienia zagadnień gramatycznych. Podobny jest bowiem wybór tematów, kolejność ich przedstawiania, wybór przykładów, wreszcie - sama metoda przedstawiania. Późniejsze gramatyki nie były wzorowane na gramatyce Rotha, gdyż, jak wspomniano wcześniej, ta istniała jedynie w postaci manuskryptu, i to manuskryptu najprawdopodobniej pilnie strzeżo-

57 Za: R. Hauschild, op. cit., s. 195-202. Dokładne informacje dotyczące zawartości i ewentualnych źródeł, na których oparł swoją gramatykę $\mathrm{H}$. Roth, podaję według poprawionej przez Jeana-Claude’a Mullera wersji tego artykułu, znajdującej się w tłumaczeniu tegoż na język angielski, zatytułowanej Notes on the Content of the Three Manuscripts of Heinrich Roth, zamieszczonej w ramach wstępu do książki The Sanskrit Grammar and Manuscripts of Father Heinrich Roth S.J., s. 13.

58 Warto dodać, iż z tej gramatyki korzystali późniejsi, XIX-wieczni, przede wszystkim brytyjscy, badacze sanskrytu. Została ona opublikowana relatywnie bardzo wcześnie, bo już w roku 1807 w Serampore, a w 1826 w Kalkucie. Była zatem łatwo dostępna także w Europie. Stąd zresztą prawdopodobnie wynikają podobieństwa, które da się zauważyć, gdy porównuje się je z nieznaną w Europie przez długie lata, bo aż do XX wieku, gramatyką Rotha. 
nego ${ }^{59}$. Podobieństwo metody musiało wynikać z opierania się na tej samej linii tradycji indyjskiej. Od braminów przekazujących tę właśnie tradycję uczył się sanskrytu Roth i od indyjskich panditów czerpali swoją wiedzę mający przybyć do Indii dużo później inni badacze europejscy ${ }^{60}$. Niewątpliwie można stwierdzić, iż to właśnie ojciec Heinrich Roth był jednym z pierwszych Europejczyków, którzy bardzo rzetelnie i dogłębnie przestudiowali tajniki sanskrytu. Analiza pozwala na wskazanie, iż gramatyka ta, bezspornie zawierająca informacje pochodzące ze źródeł indyjskich, wzorowana jest, także co do sposobu przedstawiania zagadnień gramatycznych, na istniejących wtedy gramatykach greckich czy łacińskich. Taka jest jej struktura. W opisie poszczególnych form gramatycznych Roth używa łacińskiej terminologii gramatycznej. Ta ostatnia nie zawsze jest w pełni adekwatna. Tak jest np. wtedy, gdy opisywane są funkcje przypadków albo używane nazewnictwo czasów przeszłych (imperfectum, perfectum), często niepokrywające się ze znaczeniami tychże czasów w sanskrycie ${ }^{61}$.

Na koniec opowieści o wieku XVII warto wspomnieć o jeszcze jednej osobie, a jest nią Holender Abraham Rogerius czy inaczej Abraham Roger (1609-1649). Nie był on misjonarzem, ale przebywał w Indiach od roku 1633, w holenderskiej faktorii w miejscowości Pulicat, w Kerali. Pracował jako tłumacz dla Dutch East India Company. Dotarł do

59 J.-C. Muller i A. Camps opisują szczegółowo, jak udało im się ją odnaleźć, mimo że znajdowała się ona wewnątrz okładek pozycji zakatalogowanych pod innymi tytułami.

so W szczególności byli to uczeni brytyjscy, których prace stały się podstawą całej lawiny XIX-wiecznych opracowań dotyczących gramatyki sanskrytu. "1 Bardzo dobrą charakterystykę tych i innych zagadnień gramatycznych $i$ ich opisów oraz charakterystyki można znaleźć np. w XX-wiecznej gramatyce, której autorem jest Ashok Aklujkar (por. A. A klujkar, Sanskrit. An Easy introduction to an Enchanting Language, Vancouver 1990). 
Indii w 1631 roku, by już w 1632 udać się do Suratu, a stamtąd właśnie do Pulicat. Osoba Rogera jest ważna, napisał on bowiem książkę De Open-Deure tot het verborgen Heydendom of te Waerachtigh vertoogh van het leven ende zeden, mitsgaders de Religie ende Gotsdienst der Bramines op de Cust Chormandel ende der landen daar ontrent ${ }^{62}$. Mimo że została ona wydana już po jego śmierci w roku 1651 w Leiden, po holendersku, to już w 1663 ukazała się w tłumaczeniu na język niemiecki w Norymberdze, a w 1670 - po francusku w Amsterdamie. Książka zatem mogła potencjalnie mieć relatywnie szeroki krąg europejskich odbiorców i to stanowiło o jej istotności. Autor zawarł w niej garść informacji na temat literatury bramińskiej oraz wybrane aforyzmy autorstwa Bhartrihariego (Bhartrhhari). Był to, najprawdopodobniej, pierwszy przekład obszerniejszych fragmentów tekstu sanskryckiego na języki europejskie ${ }^{63}$. Książka składała się z dwóch części. Pierwsza z nich dotyczyła przede wszystkim braminów i ich obyczajów, druga hinduizmu, samej wiary, jak i towarzyszących jej rytuałów. Najprawdopodobniej Roger spotykał się przez kilka lat z trzema braminami i to oni właśnie przekazywali mu wiedzę o kulturze indyjskiej. Powrócił do Holandii w roku 1647. Johann Gottfried Herder (1744-1803) swoją słynną książkę Stimmen der Völker in Liedern oparł po części na dziele Rogera.

W wieku XVIII Europejczycy bardzo pogłębili swoją znajomość tak rozmaitych krain indyjskich, jak i sanskrytu. Do Indii, poza podróżnikami i kupcami, udało się wielu misjonarzy, którzy chcąc zbliżyć się do miejscowej ludności, starali się posiąść znajomość języków

62 W tłumaczeniu na język angielski tytuł podawany jest jako: The open door to the hidden paganism or truthful account of life and customs, as well as religion and worship of the Brahmins at Coromandel Coast and surrounding countries. o3 Posiadamy w polszczyźnie tłumaczenie poezji Bhartrihariego: Bhartrihariego strof trzykró po sto: o mądrości życia, o namiętności mitosnej i o wyrzeczeniu, Kraków 1980. Jego autorem jest Ireneusz Kania. 
lokalnych. Mimo że gdy rozważa się dokonania w zakresie opisu gramatyki sanskrytu, należy stwierdzić, że powstała w zasadzie jedna praca, której wartość także współcześnie można ocenić bardzo wysoko pod względem naukowym, dorobek wieku XVII w dziedzinie wzajemnego poznawania się Indusów i Europejczyków można określić jako imponujący.

Rozpoczynając historię dotyczącą europejskiej obecności w Indiach w XVIII wieku, warto choćby wspomnieć o Benjaminie Schultze (1689-1760), który był misjonarzem Danish-Halle Mission w południowych Indiach. W 1719 roku został wysłany na misję do Tranquebar $^{64}$. Założył też misję chrześcijańską w Madrasie, gdzie przeniósł się w roku 1726. Wraz z Peterem Maleiapennem (1700-1739) pracował nad tłumaczeniem Biblii na język tamilski. Wrócił do Halle w roku 1743. Obaj byli niewątpliwie kontynuatorami tradycji wzajemnego poznawania się Europejczyków i Indusów za pośrednictwem języków, które umożliwiały kontakty na poziomie kulturowym.

2. Jean François Pons, Codex chartaceus quo continentur Grammatica et dictionarium linguae samscretamicae

Jednym z misjonarzy, ważnym dla odkrywania sanskrytu, był z kolei niewątpliwie francuski jezuita Jean François Pons (1688-1752). Pojechał on do Indii w roku 1726 i spędził większość czasu w Bengalu. Pons pisał w roku 1740 w liście do Jeana-Baptiste'a du Halde’a, wydanym w ramach wzmiankowanej już serii Lettres édifiantes et curieuses, m.in. o wielkich indyjskich osiągnięciach w dziedzinie gramatyki sanskrytu. Oto krótki fragment tego właśnie listu:

ot Obecnie Tharangambad w Tamilnadzie. 
Gramatyka bramińska może być zaliczona do grona najpiękniejszych nauk; nigdy jeszcze analiza i synteza nie były lepiej wykorzystywane niż w dziełach gramatycznych dotyczących języka nazywanego samskret czy samskroutan. Wydaje mi się, że język ten, zachwycający swoją harmonią, obfitością i mocą, był kiedyś, w kraju zamieszkałym przez pierwszych braminów, językiem żywym ${ }^{65}$.

Pons zebrał i zakupił ogromną kolekcję manuskryptów sanskryckich. W roku 1733 dużą jej część, bo aż 168 manuskryptów, przesłał do paryskiej Bibliothèque Royale. Stała się ona początkiem zbiorów sanskryckich manuskryptów w Paryżu. Pod numerem 13 w tym zbiorze znajduje się zapisany po łacinie manuskrypt, na którym, w odróżnieniu od pozostałych, nie została zapisana cena. Jego tytuł, zachowany w języku francuskim, brzmi Rudiments de la langue Samskretane en Latin. Brak ceny sprawia, iż pojawiły się przypuszczenia, że jest to dzieło samego Ponsa. To właśnie z tej gramatyki, jak pisze J.-C. Muller, korzystali niektórzy ze studiujących później sanskryt w Paryżu, m.in. Antoine-Léonard de Chézy (1773-1832) i Friedrich Schlegel (17721829). J.-C. Muller twierdzi, iż jeszcze jedna z gramatyk, zatytułowana Codex chartaceus quo continentur Grammatica et dictionarium linguae samscretanicae, jest dziełem J. F. Ponsa ${ }^{66}$.

Gramatyka ta składa się z pięciu rozdziałów. Pierwszy z nich, zatytułowany De litteris, poświęcony jest alfabetowi, podziale głosek ze względu na miejsce ich artykulacji, stopniowaniu samogłosek i zjawi-

65 Cyt. za: J.-C. Muller, op. cit., s. 134 („La grammaire des brahmanes peut être mise au rang des plus belles sciences; jamais l'analyse et la synthèse ne furent plus heureusement employées que dans leurs ouvrages grammaticaux de la langue samskret ou samskroutan. Il me paraît que cette langues, si admirable par son harmonie, son abondance et son énergie, était autrefois la langue vivante dans les pays habités par les premieres brahmanes").

o6 Ibidem, s. 135. 
sku sandhi. Podano też wyjątki. Rozdział 2 De pronominibus zawiera zestawienia zaimków pytających, względnych i wskazujących, a także paradygmaty ich odmian oraz opisy ich funkcji. W rozdziale $3 \mathrm{De}$ declinatione nominum opisano ogólne reguły odmiany kategorii nomen oraz podano 46 paradygmatów odmian. W rozdziale 4 , zatytułowanym De coniugatione verborum, w sposób ogólny opisuje się kategorię verbum. Podane są listy końcówek, przedstawione informacje dotyczące trybów, systemów czasów, augmentów, infiksów oraz koniugacji pochodnych (causativum, desiderativum itd.). To, że zawarto w nim także listę rdzeni czasownikowych zgodną z klasyfikacją Wopadewy, wskazuje jednoznacznie na to, iż gramatyka tego ostatniego była źródłem informacji. Nie jest natomiast jasne, czy jedynym źródłem. $\mathrm{Z}$ kolei rozdział 5 Paradigma conjugationis primitivum zawiera pełny paradygmat odmiany rdzenia $\mathrm{kṛ}$ i niekompletny paradygmat odmiany rdzenia bhū. Ta właśnie niedoskonałość wskazuje na to, iż praca była najprawdopodobniej niedokończona przez autora. Sama gramatyka jest bardzo podobna w konstrukcji, choć mniej szczegółowa, do tej napisanej przez Heinricha Rotha.

\section{Johann Ernst Hanxleden, Grammatica Grandonica}

Niemiecki jezuita Johann Ernst Hanxleden (1681-1732), znany i zapamiętany przede wszystkim w Kerali, jego głównym terenie działania, jako Arnos Padre, a także jako Arnos Paathiri czy Arnos Padri albo Arnos Padiri, był kolejną postacią ważną w dziele poznawania języków indyjskich, w tym sanskrytu. Urodzony w Osterkappeln w Niemczech już jako młodzieniec przystąpił do misji jezuickich. Przybył do Indii, do miejscowości Surat znajdującej się w obecnym Gudżaracie w roku 1700 . Wkrótce podążył na Goa, gdzie od dawna istniała już jezuicka tradycja misji do Indii. Bardzo szybko został posłany do jezuickiego seminarium w Ambalakad, w centralnej Kerali, na dalekie 
południe Indii. Tam właśnie zdobył wykształcenie, by następnie oddać się ewangelizacji miejscowej ludności. Ponieważ językiem tego terenu był język malajalam, Hanxleden, jako osoba utalentowana językowo, wkrótce posiadł jego znajomość. W poznawaniu języka malajalam pomagali mu dwaj bramini. Był pierwszym, który napisał słownik języka malajalam. Słownik ten skonstruował w taki sposób, że słowom w malajalam towarzyszyły ich odpowiedniki w języku portugalskim i w sanskrycie. Jest też autorem kilku

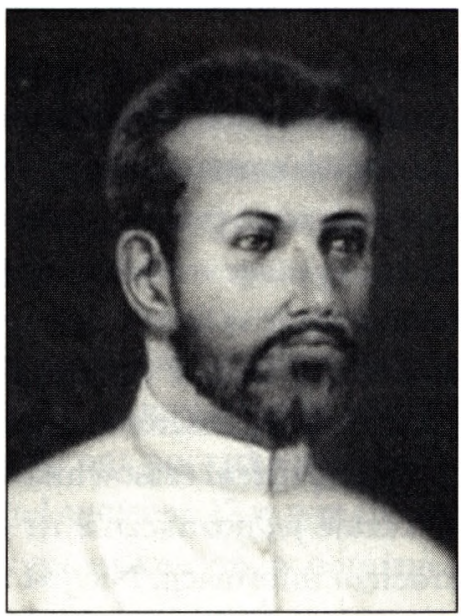

6. Johann Ernst Hanxleden tekstów napisanych po łacinie. Oparł je na swojej znajomości zawartości dwóch najsłynniejszych eposów indyjskich Mahabharaty (Mahābhārata) i Ramajany (Ramāyaṇa). Hanxleden napisał także krótką gramatykę języka malajalam. Jest autorem gramatyki sanskrytu zatytułowanej Grammatica Grandonica oraz słownika sanskrycko-portugalskiego Dictionarium Sanscridamico-Lusitanum ${ }^{67}$. Hanxleden władał doskonale wieloma językami - poza wymienionymi także niemieckim, syryjskim i tamilskim. Był również badaczem, który skopiował i zaopatrzył w notatki niektóre z manuskryptów sanskryckich, w szczególności te o charakterze gramatycznym, a pośród nich także prace poświęcone leksyce. Znalazł się tu słynny słownik Amarasimha (Amarasimnha) oraz Siddharupa (Siddharūpa), opisywana jako Wjakarana (Vyākaraṇa), czyli ngrama-

67 Nazwy łacińskie prac Hanxledena pojawiają się w różnych źródłach $\mathrm{w}$ różnych zapisach. Powszechnie przyjęło się podawać je w formie, w jakiej przekazał je Paulinus a Sancto Bartholomaeo. 
tyka". Ta ostatnia to praca, w której do poszczególnych paradygmatów dodawane są skomponowane w postaci metrycznej sanskryckie strofy oraz dzieło poetyckie Judhiszthiravidżaja (Yudhișțhiravijaya) ${ }^{68}$. Siddharupa była podręcznikiem gramatyki używanym w owym czasie w Kerali jako podręcznik podstawowych reguł sanskrytu ${ }^{69}$. Jej znajomość poprzedzała rozpoczęcie nauki form właściwych językowi Wed (Weda). Hanxleden napisał też gramatykę języka malajalam oraz słownik malajalam-portugalski (Vocabularium Malabarico-Lusitanicum) i był pierwszym Europejczykiem, który skomponował kilka wersów w sanskrycie. Jedna ze strof, napisana przez Hanxledena w sanskrycie, zachowała się jedynie w jednej z prac Paulinusa ${ }^{70}$. Dzieła Hanxledena nie zostały opublikowane za jego życia. Sam autor zresztą o to nie zabiegał. Niektóre znajdowały się w różnych częściach Europy, większość została przywieziona do Paryża ${ }^{71}$. Pracą najbardziej interesującą w kontekście europejskich gramatyk sanskrytu jest niewątpliwie Grammatica Grandonica. Data jej napisania nie została do tej pory ustalona.

o8 Grammatica Grandonica..., s. 214.

69 Uzupełnieniem do niej były dwie prace. Pierwsza, zatytułowana Balaprabodhana (Bälaprabodhana), za której autora uważa się Putumanę Namputiriego (Putumana Nanpūtiri). Jest to tekst zawierający wybrane reguły gramatyczne wraz z przykładami w prostym sanskrycie, w którym niektóre z przykładów podawane sq $\mathbf{w}$ postaci strof metrycznych, oraz tekst nieznanego autorstwa Samasacakram (Samāsacakram), poświęcony w głównej mierze regułom tworzenia złożeń.

70 Paulinus a Sancto Bartholomaeo, Sidharubam seu Grammatica Samscridamica. Cui accedit Dissertatio historico-critica in linguam Samscridamicam, vulgo Samscret dictam in qua huius linguae existentia, origo, praestantia, antiquitas, extensio, maternitas ostenditur, libri aliqui ex ea exarati critice recensentur, et simul aliquae antiquissimae gentilium orationes liturgicae paucis attinguntur, et explicantur, Romae: S. C. de Propaganda Fide 1790.

$"$ Grammatica Grandonica..., s. 217. 
Uważa się, że było to pomiędzy 1712 a 1732 rokiem $^{72}$. Gramatyka ta została napisana po łacinie. Można w niej jednak znaleźć także uwagi $\mathbf{w}$ języku portugalskim. Składa się z pięciu $\mathbf{w}$ zasadzie niezależnych części. Opisane w nich zostały podstawowe reguły gramatyczne oraz podano relatywnie dużo paradygmatów odmian. W części pierwszej został opisany system nominalny. Są tu uwagi wstępne dotyczące reguł odmiany oraz przegląd paradygmatów. Opisane zostały funkcje przypadków oraz ich użycie, podane informacje na temat rodzajów i typów złożeń nominalnych. Część druga została poświęcona systemowi czasownikowemu. Trzy kolejne, mniej rozbudowane części dotyczą składni przypadków, reguł sandhi oraz reguł tworzenia form adwerbialnych. Gramatyka Hanxledena wywodzi się zarówno z wiadomości pochodzących $z$ tradycji indyjskiej, jak i z tych istniejących już w tradycji europejskiej. Hanxleden podaje paradygmaty odmian form nominalnych w tradycyjnym indyjskim układzie przypadków, zachowując właściwą tradycji indyjskiej kolejność, ale ich nazwy podaje po łacinie ${ }^{73}$. Jest niewątpliwie pracą o charakterze opisowym, ale też pragmatycznym w sensie celu jej napisania. Zawiera niewiele błędów. Niektóre z nich wyglądają na błędy, które Hanxleden powtarza w ślad za tymi, których dokonali kopiści przepisujący manuskrypty. Hanxleden bowiem najprawdopodobniej korzystał i z takich manu-

\section{Ibidem, s. 215.}

73 Pierwszy przypadek prathama (prathamā) opisany jest zatem jako nominativus, specjalny pierwszy przypadek prathama (prathamā) jako vocativus, drugi dwitija (dvitīyā) jako accusativus, trzeci tritija (trtīyāa) jako ablativus 1 (jest to przecież łaciński instrumentalis), czwarty czaturthi (caturthī) jako dativus, piąty pańćami (pańcamī) jako ablativus 2 , szósty szaszthi (șașthī) jako genetivus i ablativus 2 , i wreszcie siódmy saptami (saptamī) jako ablativus 3 (jest to łaciński locativus). Można zatem zadać pytanie, na ile pomocne jest podawanie w tym kontekście łacińskich terminów, skoro bywają one tak nieadekwatne. 
skryptów. Wiadomości o pracach Hanxledena pojawiły się dopiero w dziełach Paulinusa a Sancto Bartholomaeo i dopiero wtedy, choć pośrednio, niektórzy z naukowców europejskich usłyszeli o tym wybitnym badaczu.

W tym miejscu należy dodać kilka słów dotyczących kontekstu historycznego. Otóż cały wiek XVIII oraz pierwsza połowa wieku XIX są uważane za okres, w którym w Indiach ścierały się dwie potęgi - istniejące już od dawna i dobrze osadzone na terenach indyjskich państwo Mogołów oraz Indie Brytyjskie. Rywalizowały one o hegemonię nad terenami indyjskimi, z których wiele pozostawało jeszcze we władaniu poszczególnych państw i państewek indyjskich. O ile państwo Mogołów jest nieistotne w odniesieniu do interesującego nas tematu europejskich gramatyk sanskrytu, o tyle prace przybyłych wraz z Kompanią Wschodnioindyjską Brytyjczyków miały na tę tradycję ogromny wpływ.

Kompania Wschodnioindyjska pojawiła się w Indiach z początku w celach handlowych. Wkrótce jednak jej przedstawiciele zaczęli rywalizować z lokalnymi władcami.

Wystarczy rzut oka na mapy Indii z 1772 i 1856 roku, aby się przekonać, jak szybko powiększał się stan posiadania Wielkiej Brytanii ${ }^{74}$. Jak pisze Jan Kieniewicz w książce Wprowadzenie do historii cywilizacji Wschodu i Zachodu, Anglicy potrafili wykorzystywać wewnątrzindyjską rywalizację o władzę, by stopniowo podbijać terytorium Indii. Wprowadzali zmiany tak w nowej administracji, jak i w sądownictwie, m.in. poprzez wprowadzenie języka angielskiego jako obowiązującego np. w urzędach czy szkolnictwie ${ }^{75}$.

\footnotetext{
74 Por. J. Kieniewicz, op. cit., s. 501, 630.

7 Idem, Wprowadzenie do historii cywilizacji Wschodu i Zachodu, Warszawa 2003, s. 253-255.
} 
Pytanie, które niewątpliwie należy zadać w kontekście pierwszych nowożytnych kontaktów Europejczyków z Indusami, brzmi: jak udawało im się porozumieć? Niewątpliwie w pierwszej kolejności należy tu wymienić otwartość na innego i chęć kontaktu, wolę poznawania odmiennej kultury, jej języka czy języków, religii etc. Możliwość komunikacji pojawiała się dopiero wówczas, gdy udawało się poznać wspólne obu stronom języki. Europejczycy starali się zatem uczyć języków lokalnych. Niewątpliwie pomagała im w tym ludność miejscowa. Najprawdopodobniej byli to nie tylko uczeni, ale także prości mieszkańcy, z którymi Europejczycy, a w szczególności misjonarze, chcieli się porozumiewać. Żeby jednak poznawać sanskryt, niezbędne było znalezienie uczonych braminów, którzy taką wiedzą chcieliby się podzielić. Pośród niektórych z otwartych na kontakty Indusów Wilhelm Halbfass wymienia np. uczonego indyjskiego Maridasa Poullé (Mariyadās Pillai) urodzonego w 1721 roku, który poza rodzimym tamilskim znał też francuski i łacinę. Przyjął on z czasem chrześcijaństwo i został tłumaczem Kompanii Francuskiej oraz autorem przekładu na język tamilski jednej z oryginalnie zapisanych w sanskrycie puran (purāṇa), a mianowicie Bhagawatapurany (Bhāgavatapurāṇa) ${ }^{76}$. Ta $\mathrm{i}$ inne purany miały zresztą stać się jednymi z częściej tłumaczonych na języki europejskie dzieł literatury staroindyjskiej ${ }^{77}$.

76 W. Halbfass, op. cit., s. 88.

77 Obszerne współczesne opracowania dotyczące puran to np. książka Ludo Rochera The Purānas (Wiesbaden 1986) czy wydany w roku 2006 w ramach serii Blackwell Companion to Hinduism tekst pióra F. Matchett The Purānas (F. Matchett, The Purānas, [w:] The Blackwell Companion to Hinduism, red. G. Flood, Bodmin 2003). 


\section{Paulinus a Sancto Bartholomaeo, Sidharubam seu grammatica Samscridamica i Vyacarana seu locupletissima Samscridamicae linguae institutio}

Paulinus a Sancto Bartholomaeo (1749-1806) ${ }^{78}$, urodzony w Austrii karmelita pochodzenia chorwackiego, przez długi czas był uważany za autora najstarszej gramatyki sanskrytu napisanej przez Europejczyka. Jego dzieło zatytułowane Sidharubam seu Grammatica Samscridamica. Cui accedit Dissertatio historico-critica in linguam Samscridamicam, vulgo Samscret dictam zostało bowiem wydane drukiem w Rzymie w roku $1790^{79}$. To właśnie w Dissertatio..., które właściwie jest raczej wstępem do gramatyki sanskrytu niż samą gramatyką, można odnaleźć przemyślenia Paulinusa dotyczące pochodzenia zarówno tego, jak i innych języków

78 Znany również jako Filip Vesdin, Filip Vezdin, Philipp Wessdin, Fra Paolino de St Bartholomaeo, P. Paolino da S. Bartollomaeo czy Paulinus Padiri. Więcej informacji można znaleźć w artykule: M. Jauk-Pinhak, Some Notes on the Pioneer Indologist Filip Vesdin (Paulinus a Sancto Bartholomaeo), „Indologica Taurinensia” 1984, vol. 12, s. 129-137. Pisze o nim także: I. Andrijanić, $A$ list of Sanskrit and Latin Cognates in Vesdin's Treatise De latini Sermonis Origine, "The Journal of Indo-European Studies” 2017, vol. 45, nr 3-4, s. 195-233.

79 Jego praca (której pełny tytuł brzmiał Sidharubam seu grammatica samscridamica cui accedit dissertatio historico-critica in linguam samscridamicam vulgo Samscret dictam in qua huius linguae existentia, origo, praestantia, antiquitas, extensio, maternitas ostenditur, libri aliqui ea exarati critice recensentur, et simul aliquae antiquissimae gentilium orationes liturgicae paucis attinguntur, et explicantur - Auctore Fr. Paolino a S. Barholomaeo, Carmelita Exalceato Malabriae Missionario) została ponownie wydana wraz z tłumaczeniem na język angielski przez Ludo Rochera. Por. L. Rocher, Paulinus a Sancto Bartholomaeo, Dissertation on the Sanskrit Language, a reprint of the original Latin text of 1790, together with an introductory article, a complete English translation, and an index of sources, Amsterdam: John Benjamins Publishing Company 1977. 


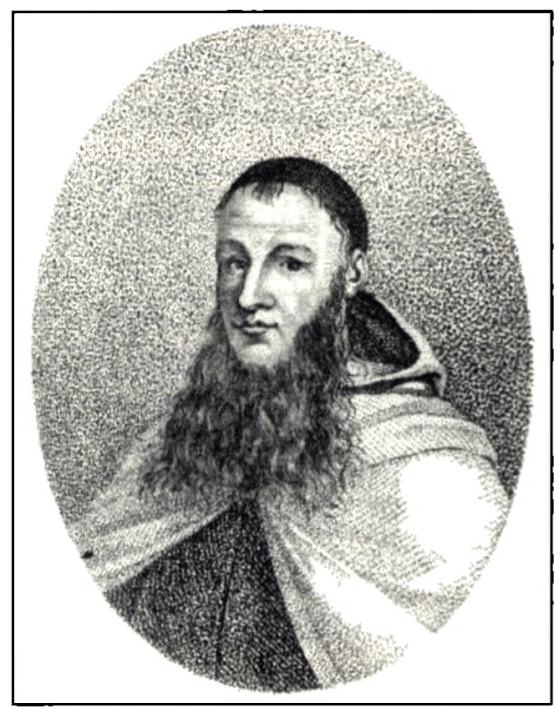

7. Paulinus a Sancto Bartholomaeo

indyjskich. Pojawiają się tu pytania odnośnie do ich wzajemnych relacji, a także do języków występujących poza Indiami. Można zatem uznać, iż Paulinus wpisuje się do pewnego stopnia w refleksję nad możliwym językoznawstwem porównawczym. Oczywiście raczej na poziomie pytań niż dowodów czy odpowiedzi ${ }^{80}$. To nie kto inny jak Paulinus w swojej książce De Latini sermonis origine et cum orientalibus linguis connexione, wydanej w Rzymie w roku 1802, stwierdza:

[...] chociaż bowiem Germanowie, Grecy, ludy romańskie i Indusi są oddaleni od siebie wielkimi przestrzeniami, to ich języki wskazują na wspólne ich pochodzenie i przynależność do jednej wspólnej rodziny [... ${ }^{81}$.

Ludo Rocher zastanawia się nad tym, na których źródłach mógł opierać swą wiedzę Paulinus. Za bardzo wartościowy uważa fakt

${ }^{80}$ Tu dobrze będzie wspomnieć, że za ojca językoznawstwa porównawczego uważa się Franza Boppa, który drogę wskazał później, bo w roku 1816, w swojej pracy Conjugationssystem... Niewątpliwie dopiero w tym dziele można znaleźć szeroką, naukową argumentację popartą licznymi przykładami. ${ }^{81}$ "[...] quamvis enim Germani, Graeci, Latini et Indi maximis locorum intervallis inter se sunt disiuncti, eorum tamen linguae unam harum gentium eamque communem originem satis indicant et omnes in unam primaevam familiam referuntur $[\ldots]$. 
zamieszczenia przez niego spisu tychże właśnie w Dissertatio... ${ }^{82}$. To pytanie jest zresztą istotne nie tylko w odniesieniu do prac Paulinusa. Wielokrotnie autorzy gramatyk nie zamieszczają informacji o źródłach, z których korzystali. Trzeba wtedy próbować rekonstruować je na podstawie ich treści czy struktury. Nie zawsze daje to wystarczająco zadowalające wyniki. Paulinus już w pierwszych wersach wymienia niektóre ze swoich źródeł. Pisze o nich, przywołując imiona autorów, którzy w swoich pracach nadawali sanskrytowi określone nazwy:

Athanasius KIRCHER called it Hanscret; Thomas HYDE, Sanscroot; MULLER, Edward BERNARD, and Charles MORTON, Hanscret; Father CALMETTE, in a letter to Father TOURNEMINE, written in 1737 from Vekatiguiri in the Carnatic kingdom, Samscroustam; SONNERAT, Samscroudam; ANQUETIL DU PERRON, Samskretam; Etienne FOURMONT, Samscretan; MALLET DUPAN, Sanscreet; an anonymous Jesuit missionary, Grandon; Father Agostino Antonio GIORGI, Samscret; the authors of the ASIATICK RESEARCHES, Sanscrit $i$ Shanscrit; the author of the preface to ALPHABETUM BARMANORUM, Samscrit; Father Giuseppe BESCHI, Grandon and Samskrdam, Giovanni Cristoforo AMADUZZI, Samscrit; Father CLEMENS A IESU, Grando nor Samskrdam; finally, the author of GRAMMATICA TALENGANICA, Samscredam, Jesuit missionary. It has also been given this name by $\mathrm{Fa}-$ thers VINCENZO DI S. CATERINA DA SIENA, GEMINIANUS A S. OCTAVIO, STEPHANUS A SS. PETRO ET PAULO, AND ILDEPHONSUS A PRAESENTATIONE, my predecessors in Malabar, whose Indian diaries and reports - those edited in print, those preserved in the archives of the house of the Verapoli mission, and those which I have in my possession - all agree on this one point ${ }^{83}$.

\section{${ }^{82}$ L. Rocher, op. cit., s. XX-XXI.}

B3 To wersja tego fragmentu, oryginalnie zapisanego po łacinie, $w$ angielskim tłumaczeniu L. Rochera (ibidem, s. 82). 
Paulinus, wskazując na różnice, które pojawiają się już w samej nazwie podawanej przez Europejczyków, stwierdza, że te informacje wskazują niewątpliwie na istnienie języka, języka świętego, używanego przez braminów tak do celów naukowych, religijnych, jak i literackich $^{84}$. Dodaje, że niektórzy ze wzmiankowanych autorów sugerują, iż język ten jest już wymarły, istnieje jedynie w dziełach literackich i jest używany wyłącznie przez przedstawicieli najwyższej warstwy społeczeństwa indyjskiego.

O źródłach, z których korzystał, Paulinus pisze, wskazując jako swego mistrza Johannesa Hanxledena. Nie zetknął się osobiście z Hanxledenem, jako że przybył do Indii więcej niż 40 lat po śmierci tego ostatniego. Mimo to właśnie prace Hanxledena były podstawą jego dzieł" ${ }^{\sharp 5}$. Zresztą od czasu do czasu wprost cytuje ich fragmenty. Wielu późniejszych badaczy europejskich miary Maxa Müllera (1823-1900), Friedricha Wilhelma Schlegla (1772-1829) czy Theodora Benfeya wypowiadało się niezwykle pozytywnie na temat wiedzy Hanxledena. Jego gramatyka długo jednak pozostawała nieznana. Dopiero w roku 2010 gramatyka ta została odnaleziona w bibliotece Convento di San Silvestro, w Monte Compatri w Lazio we Włoszech, w okolicach Rzymu. Szczęśliwym odkrywcą był Toon Van Hal ${ }^{86}$.

Sidharubam seu Grammatica Samscridamica była pierwszym dziełem na długiej liście prac autorstwa Paulinusa a Sancto Bartholomaeo. $\mathrm{Za}$ jedno $\mathrm{z}$ ciekawszych, $\mathrm{z}$ punktu widzenia przedstawień dotyczących gramatyki, można uznać krótkie, bo liczące zaledwie 24 strony,

\section{Ibidem, s. 83.}

85 Paulinus spotkał w Kerali uczniów Hanxledena oraz odnalazł kilka $z$ pozostałych po nim manuskryptów. Niektóre $\mathbf{z}$ nich były już przewiezione do Europy, podczas gdy inne, te znalezione w Kerali, zostały do Europy przywiezione później, właśnie przez Paulinusa.

86 Dwaj badacze Toon Van Hal i Christophe Vielle wydali tekst tej gramatyki wraz z obszernym wstępem i komentarzem. 
przedstawienie kilku alfabetów indyjskich zatytułowane $A$ lphabeta Indica, id est Granthamicum seu Samscridamico-Malabaricum Indostanum sive vanarese nagaricum Vulgare et Talenganicum, które ukazało się w Rzymie w roku 1791. Warta wzmianki jest także obszerna, licząca 404 strony, wydana w roku 1796 i wkrótce, bo już po dwóch latach, przetłumaczona na język niemiecki praca Paulinusa zatytułowana Viaggio alle Indie Orientali ${ }^{87}$.

Przedstawienie samej gramatyki sanskrytu Paulinus wydał w roku 1804. Zatytułował je Vyacarana seu locupletissima Samscridamicae linguae institutio. Książka ta składała się z siedmiu rozdziałów. Rozdział 1 był zatytułowany De Samscrdamicis litteris. Opisano w nim system fonologiczny sanskrytu. Rozdziały 2 i 3 dotyczyły systemów odmiany rozmaitych form kategorii nomen i były zatytułowane De Nominum declinationibus. Zawierały one także ilustrujące poszczególne zagadnienia przykłady. Rozdział 4 o tytule ogólnym De conjugationibus verborum dotyczył systemów koniugacyjnych, form pasywnych, czasowników nietypowych oraz koniugacji pochodnych. W nieposiadającym ogólnego tytułu rozdziale 5 opisano składnię oraz funkcje przypadków. Przysłówkom, prepozycjom, participiom i gerundium poświęcony był kolejny rozdział zatytułowany De analysi constructionum, de adverbiis, praepositionibus et coniuctionibus. Wreszcie ostatni rozdział (7), o tytule Nomenclator Latino-Samscrdamicus, dotyczył słownictwa. $\mathrm{Na}$ zakończenie Paulinus zaopatrzył książkę w przykłady poszczególnych

87 Tłumaczem na język niemiecki był Reinhold Forster, który nadał książce tytuł Des Fr. Paolino Reise nach Ostindien. W języku angielskim pt. A Voyage to the East India ukazała się ona już w roku 1800. Było to tłumaczenie nie bezpośrednie, lecz z języka niemieckiego, a jego autorem był Frederick William Johnston (1872-1947). Wreszcie w roku 1808 pojawiła się jego wersja francuska, zatytułowana Voyage aux Indes Orientales. Avec les observations de MM. Anquetil du Perron, J. R. Forster et Silvestre de Sacy. Była ona rozszerzona o obszerne komentarze. 
form gramatycznych i charakterystycznych dla sanskrytu konstrukcji. Dodał także kilka informacji o liczebnikach. Jego gramatyka zawierała też, co nie tak częste w owych czasach, bibliografię. Można dodać, iż Paulinus wiedział, że dla poznawania języka bardzo ważne jest uzupełnianie samych gramatyk przez słowniki. Wybrał z gamy słowników indyjskich ten uważany $w$ Indiach za jeden z najważniejszych, czyli ten, o którym wspominano już wcześniej, zatytułowany Amara Sinha. Wydał jego pierwszą część już w roku 1798 i zatytułował ją Amara Simha. Sectio prima de Caelo ex tribus ineditis codicibus Indicis manuscriptis (Amara Simha. Część pierwsza, o Niebie, na podstawie trzech niewydanych rękopisów indyjskich) ${ }^{88}$. Paulinus był bardzo płodnym autorem. Napisał i wydał też wiele innych prac dotyczących religii, szeroko rozumianej kultury, geografii i historii Indii. Nie sposób tu omówić, choćby pokrótce, wszystkich jego prac ${ }^{89}$.

Paulinus przebywał w Indiach 13 lat (1776-1789), głównie w Kerali (na wybrzeżu Malabarskim) w południowych Indiach. Do Europy (do Rzymu) powrócił w roku 1789. We fragmentach dotyczących źródeł indyjskich używał w swoich pracach jednej $z$ form alfabetu grantha. Dodatkowo podawał cytaty w łacińskiej transliteracji. Sposób, w jaki transliterował, odbiegał oczywiście od transliteracji obowiązującej współcześnie, jednak stosował go konsekwentnie. Z tekstów, które pozostały po Paulinusie, wynika, że poza dziełami literackimi samymi w sobie korzystał też z komentarzy do nich. Wskazuje to na dobrą orientację w tradycji indyjskiej, w której komentarze są bardzo istotnym elementem odczytywania dzieł. Zdaniem Ludo Rochera, Paulinus szedł nierzadko w odczytywaniu tekstów sanskryckich za

${ }_{88}$ Już w Sidharubam seu Grammatica Samscridamica Paulinus opisywał zawartość tego słownika i wskazywał na jego odmienny od słowników europejskich charakter.

89 Dokładny spis wszystkich odnalezionych do tej pory dzieł Paulinusa można znaleźć w: L. Rocher, op. cit., s. IX-XI. 
swoim indyjskim panditem (paṇitit). Interpretacje te czynił jednak zrozumiałymi w ramach tradycji łacińskiej ${ }^{90}$. Paulinus prowadził dysputy na temat kultury indyjskiej i sanskrytu ze współczesnymi mu badaczami. Między innymi z francuskim znawcą języków orientalnych Abrahamem Hyacinthe'em Anquetil-Duperronem (1731-1805). Ten pisał o jednej z prac Paulinusa, co następuje:

Fragment ten dowodzi, że Misjonarz nie przeczytał dzieł teologicznych ani filozoficznych ułożonych przez Indusów i że prawdopodobnie nie znał więcej sanskrytu niż tyle, ile mógł się nauczyć ze słowników przetłumaczonych na języki europejskie oraz z prac swoich współbraci, które złożone były w bibliotece [... $]^{\mathrm{n} 91}$.

Paulinus dyskutował też z przybyłymi już wcześniej do Indii orientalistami brytyjskimi. Przez wielu badaczy, i to zarówno mu współcze-

$90 \quad$ Ibidem, s. XXVII.

91 "This passage proves that the Missionary has not read the theological and philosophical books composed by the Indians, and that he probably did not know more Sanskrit than from what he found in the dictionaries of Propaganda, translated into some European language, and in the works of his confreres which have been deposited in the library [...]". Abraham Hyacinthe Anquetil-Duperron przybył do Indii, do Pondicherry w roku 1755. Studiował tam języki orientalne, m.in. język perski, tamilski i telugu. W roku 1760, po swoich licznych podróżach zgromadził kolekcję około 180 manuskryptów w wielu językach indyjskich. Kolekcję tę zdeponował następnie w Bibliothèque du Roi, w Paryżu. Duperron znał jednak sanskryt w stopniu daleko niedoskonałym (o ile w ogóle można stwierdzić, iż go znał). Swoje badania prowadził na podstawie tłumaczeń na język perski. Pytaniem zasadnym jest w związku z tym, czy był uprawniony do wypowiadania takich krytycznych uwag względem prac Paulinusa (ta ostatnia uwaga pochodzi od K. Karttunena). 
snych, jak i późniejszych, jego prace były bardzo mocno krytykowane ${ }^{92}$. Paulinus zresztą nie pozostawał im dłużny. O Brytyjczykach pisał z pewną dozą pogardy "Angli Calcuttenses" ( Krytykował także wielu europejskich misjonarzy. Był to niewątpliwie czas, kiedy nikt nie posiadał naprawdę pełnej i ugruntowanej wiedzy o gramatyce sanskrytu. Zarówno równolegle $z$ nim działający na niwie poznawania sanskrytu badacze brytyjscy, jak i - a może nawet szczególnie - później już, bo w XIX wieku, zajmujący się sanskrytem badacze niemieccy tej miary co August Wilhelm Schlegel (1767-1845) bardzo krytykowali jego gramatyki, a w szczególności przestrzegali przed używaniem ich w celu badań porównawczych. Wiadomo jednak, że np. jeden z pierwszych i bardzo szanowanych francuskich znawców sanskrytu Francuz Antoine-Léonard de Chézy korzystał w studiach nad sanskrytem także z prac Paulinusa ${ }^{93}$. W Europie, odkąd pojawiła się możliwość dostępu do prac badaczy brytyjskich, w szczególności Williama Jonesa, Thomasa Colebrooke'a, Charlesa Wilkinsa czy Horace’a Haymana Wilsona, nie było już konieczne sięganie do opracowań Paulinusa, chociaż przesadą byłoby stwierdzenie, iż były one kompletnie zapomniane czy bezwartościowe ${ }^{94}$. Nierzadko można spotkać się ze stwierdzeniem, że to właśnie w Kalkucie, ze względu na prace

92 Paulinus uczył się sanskrytu w Kerali, badacze brytyjscy zaś w Bengalu, stąd $\mathbf{z}$ pewnością pojawiały się niektóre $\mathbf{z}$ różnic $\mathbf{w}$ ich opisach gramatyki sanskrytu.

93 Chézy, aby dobrze poznać sanskryt, zapoznał się także z jego gramatyką autorst wa Charlesa Wilkinsa około roku 1808, stając się ekspertem, z którego wiedzy korzystali badacze przybywający do Paryża w celu poznawania sanskrytu. W roku 1814 ustanowiono dla niego w Collège de France katedrę sanskrytu. Jego uczniami byli naukowcy tej miary co, wspominany już, August von Schlegel, Burnouf (ojciec i syn), Kosegarten, Christian Lassen, a także w pewnym stopniu Franz Bopp.

94 Najlepszym na to dowodem jest fakt, iż nawet $w$ czasach nam współczesnych są one wciąż analizowane. 
prowadzone tam przez badaczy brytyjskich związanych z działalnością Kompanii Wschodnioindyjskiej, narodziły się pierwsze dogłębne i w pełni naukowe studia nad gramatyką sanskrytu. Prace Paulinusa są jednak dowodem na to, że takie badania były prowadzone takize w południowych Indiach. Badacze brytyjscy w tym samym czasie zainteresowali się bardzo tak literaturą, jak i językami starożytnych i nowożytnych Indii. Paulinus odnosił się do niektórych $z$ ich prac, wzmiankował relatywnie często nazwiska niektórych Brytyjczyków. Co ciekawe, w swoich początkowych opracowaniach nie wymieniał nazwiska Williama Jonesa, by potem, ale dopiero w roku 1799, uznać go za autorytet ${ }^{95}$. 



\section{Część III}

\section{Gramatyki sanskrytu w języku angielskim - XIX wiek}



D ierwszy statek będący własnością powołanej w celach handlowej wymiany towarów $z$ Indiami brytyjskiej Kompanii Wschodnioindyjskiej przybył do Suratu w roku 1608. Wkrótce, w ślad za Holendrami, Anglicy przybyli na Wybrzeże Koromandelskie, gdzie w roku 1611 założyli faktorię w Masalipatam. Już w latach 1615-1619 powstały brytyjskie faktorie nie tylko w Suracie, lecz także m.in. w Agrze i A hmadabadzie. To był dopiero początek działań Kompanii Wschodnioindyjskiej na terenach indyjskich. Kupcy brytyjscy handlowali ogromną ilością towarów, w tym indygiem, bawełną, jedwabiem, dywanami, pieprzem czy najrozmaitszego charakteru orientalnymi pachnidłami i wonnościami. W drugiej połowie XVII wieku do gamy importowanych do Europy produktów doszła także saletra, herbata i kawa oraz, ale w o wiele mniejszym stopniu, tytoń. Także w drugiej połowie XVII wieku mający liczyć około 60000 mieszkańców Bombaj dołączył do listy posiadłości Kompanii Wschodnioindyjskiej. Natomiast np. w Bengalu, także w XVII wieku, Brytyjczycy starali się w miarę bezkonfliktowo współpracować $\mathrm{z}$ dzierżącymi tam ciągle jeszcze władzę Mogołami. W roku 1688 udało im się założyć swoją nową placówkę w mającej się w przyszłości przekształcić w Kalkutę miejscowości Suttanai.

Można z pewnością stwierdzić, iż wiek XVIII to okres, który niebezzasadnie jest określany jako czas podejmowania naukowych prób pozwalających na szczegółowe poznanie gramatyki sanskrytu. To czas intensy wnych kontaktów z miejscowymi znawcami i czas opisywania tego świętego języka oraz udostępniania Europie informacji na jego temat. Wiek XVIII jest niewątpliwie wstępem do tego, co w wieku kolejnym przyniosło tak obfite owoce i co umożliwiło szeroki dostęp do tajników gramatyki sanskrytu publiczności europejskiej. 


\section{William Carey, A Grammar of the Sungskrit Language}

Aż do przełomu wieków XVIII i XIX polityka Kompanii Wschodnioindyjskiej polegała na tym, by nie pozwalać na działalność misjonarską. Mimo to od końca XVIII wieku misjonarze baptyści działali np. w Bengalu, w okolicach Kalkuty. Niektórzy z nich w ramach swej działalności interesowali się bardzo tak miejscową literaturą, jak i językami, a w ramach tego, w szczególności, językiem bengalskim i sanskrytem. Za swoją bazę przyjęli Serampore (znane wtedy także pod nazwą Fredericksnagar czy Frederiknagore) ${ }^{96}$. Spośród tych misjo-

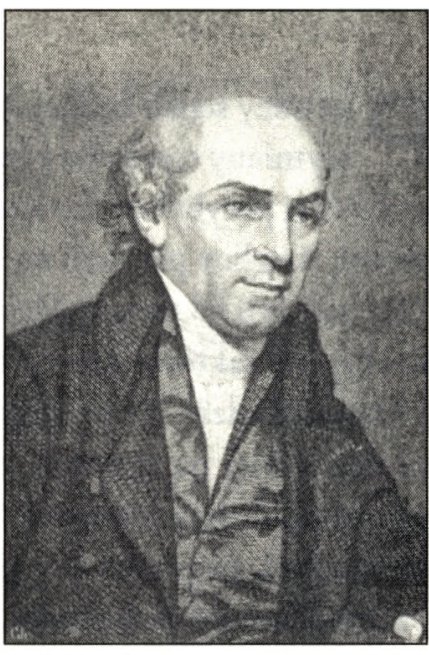

8. William Carey narzy, a zarazem badaczy i nauczycieli w kontekście sanskrytu należy wymienić przede wszystkim Williama Careya (1761-1834) przybyłego do Indii w roku 1793. Carey już jako młody człowiek, bo wieku 32 lat, przybył do Kalkuty, gdzie dał się poznać jako angielski misjonarz, kaznodzieja reformowanych baptystów i jeden z założycieli Baptystycznego Towarzystwa Misyjnego. Należy jednak dodać, iż jego działalność nie przyniosłaby owoców w dziedzinie prac ewangelizacyjnych, a i sanskrytu właśnie, gdyby nie wsparcie innych misjonarzy baptystów. Byli to Joshua Marshman (1768-1837) i jego żona Hannah Marshman (1767-1847), uważana za pierwszą misjonarkę w Indiach. Przybyli oni do Indii w roku 1799.

96 Serampore znane jest również pod nazwami Serampur, Srirampur, Srirampore, Shreerampur, Shrirampur, Shrirampore czy w języku polskim Serampur (skr. śri-Rāma-pura - miasto czcigodnego Ramy). 
Bardzo ważną postacią był też William Ward (1769-1823) ${ }^{97}$. Warto dodać, iż wszyscy oni przybyli do Serampore, oddalonego od Kalkuty o kilkanaście kilometrów na północ, znajdującego się w okręgu Hooghly w okolicy rzeki Hooghly w zachodnim Bengalu. Miejsce to znajdowało się wówczas na terenach, gdzie władzę sprawowali Duńczycy (od 1755 do 1845) ${ }^{98}$. W owym czasie przedstawiciele Kompanii Wschodnioindyjskiej byli zdecydowanie przeciwni działalności misjonarskiej. W roku 1800 Hannah i Joshua Marshman założyli w Serampore dwie szkoły przeznaczone zarówno dla dzieci misjonarzy, jak i, z czasem, dla dzieci lokalnej społeczności. Hannah odważyła się także na otwarcie szkoły dla dziewcząt.

Joshua Marshman, podobnie jak William Carey, był bardzo utalentowany językowo. Wspólnie tłumaczyli Biblį̧ na wiele języków Indii. To właśnie uważali za swój główny cel. Dodatkowo interesowali się także literaturą Indii, jako niezbędnym elementem zrozumienia kultury tego kraju. Jednym z owoców ich pracy było wydanie w latach 1802-1803 tłumaczeń obszernych fragmentów dwóch eposów indyjskich Mahabharaty i Ramajany na język bengalski. Pomocnikiem w dziele tłumaczenia Mahabharaty w wersji Kaśidasa (1802) i Ramajany w wersji Krittibasa (1803) był pandit Munshi Ramram Basu. Co ciekawe w kontekście tej pracy, Carey uważał, że miejscowi bramini nie powinni znać języka angielskiego. Dlatego też nie starał się uczyć ich swojego języka. Myślał bowiem, iż ta znajomość może wpływać na ich uzależnienie od angielskiej składni i frazeologii, tak różnej, jego zdaniem, od składni języka bengalskiego99. Pomiędzy rokiem 1806 a 1810 Carey i Marshman wydali trzy tomy tłumaczenia Ramajany

\footnotetext{
97 Por. W. Halbfass, op. cit., s. 93.

98 W roku 1845 osada Serampur została sprzedana Brytyjczykom i władzę nad nią zaczęły sprawować Indie Brytyjskie.

99 Za: J. Brockington, William Carey's Significance as an Indologist, niepublikowany artykuł (w posiadaniu autorki), s. 3.
} 
z sanskrytu na język angielski. Przekład zatytułowali The Ramayunu of Valmeeki, in the original Sungskrit. With a prose translation, and explanatory notes, by William Carey and Joshua Marshman ${ }^{100}$. Poza samą propozycją tłumaczenia zawarli też $\mathbf{w}$ książce tekst w oryginalnym sanskrycie zapisany czcionkami dewanagari. Jest to przykład rzetelnej, jak na owe czasy, pracy indologicznej. Jej wartość jest zauważana także w czasach współczesnych. Kolejne, częściowo już przygotowane do druku tłumaczenia dalszych ksiąg spaliły się podczas pożaru w roku $1813^{101}$. Tłumaczenie raczej nie posiada wartości literackiej, zostało zrobione dla celów praktycznych. Jego głównym celem było przybliżenie Europejczykom literackiej kultury Indii. Pożar strawił też rozpoczęte przez Careya dzieło natury leksykograficznej, słownik etymologiczny, który zawierał także synonimy słów w językach, zdaniem Careya, wywodzących się z sanskrytu. Carey starał się też podawać w nim ekwiwalentne słowa greckie i hebrajskie.

William Ward był z wykształcenia i praktyki drukarzem i jako taki w misji był przede wszystkim odpowiedzialny za cały proces wydawniczy. Stanowiło to niezwykle ważny element działań ewangelizacyjnych ${ }^{102}$. W latach 1800-1832 w ramach działalności Serampore Mission Press (Wydawnictwo Misyjne Serampore) wydano 212000 wolumi-

100 Tom 1 zawierał księgę pierwszą eposu i został wydany w Serampore w roku 1806 . Tom 2, wydany w roku 1809 , zawierał część księgi drugiej, a tom 3, wydany w roku 1810, pozostałą część księgi drugiej.

101 John Brockington we wzmiankowanym artykule pisze, że mimo wszystko co najmniej jeden egzemplarz fragmentu tomu czwartego uratował się $z$ pożaru i jest przechowywany $w$ Indian Institute Library w Oksfordzie (J. Brockington, op. cit., s. 8).

102 Ich maszyna drukarska była używana do druku książek w 40 językach. Używano zatem $w$ procesie wydawniczym dużej liczby alfabetów $i, \operatorname{co~} z$ tego wynika, co najmniej 14 różnych rodzajów czcionek. W roku 1812 drukarnię, w której znajdowały się czcionki niezbędne do druku, strawił wspominany już pożar. 
nów (!). Były to przede wszystkim tłumaczenia Biblii na języki lokalne, ale także książki z zakresu historii, literatury, gramatyki czy wreszcie słowniki oraz rozmówki. Były to także prace $z$ dziedziny filozofii oraz mitologii. Wszystkie one były niewątpliwie bardzo pomocne w obustronnym odkrywaniu i poznawaniu innej kultury. Drukowano tam także pierwszą gazetę, dwutygodnik, wydawany w języku bengali i angielskim zatytułowany „Samachar Durpun”, co można przetłumaczyć jako nZwierciadło Wiadomości”. Pierwszą z kolei opublikowaną książką było tłumaczenie Ewangelii św. Mateusza na język bengalski. Ward był autorem wielu prac dotyczących Indii. Spośród nich warto wspomnieć o dwóch wydanych w Serampore w roku 1811. Pierwszej, składającej się z czterech tomów i zatytułowanej Account of the writings, religion and manners of the Hindoos oraz drugiej, zatytułowanej Brief memoire of Krishna Pal, the first Hindoo in Bengal, who broke the chain of the cast by embracing the Gospel. To właśnie William Ward, Joshua Marshman i William Carey w roku 1818 powołali do życia niezwykle istotną, także dla studiów lingwistycznych, instytucję. Był to College for the instruction of Asiatic, Christian, and other Youth in Eastern Literature and European Science. Tak narodził się Serampore College, który od tamtej pory do dnia dzisiejszego był i jest niezwykle istotną placówką naukową ${ }^{103}$. Jest to najstarszy uniwersytet w Indiach, który działa nieprzerwanie od dnia swego powołania do istnienia. Ważne jest to, że jako zasadę przyjęto, iż jego studenci mogą pochodzić z dowolnego kraju czy kasty. Są przyjmowani niezależnie od ich wyznania, koloru skóry czy płci.

103 Obecnie pobiera tam nauki ponad 2000 studentów, a mottem tej instytucji jest pochodząca z Biblii maksyma „Gloriam Sapientes Possidebunt" - ${ }_{\text {n Mądrzy }}$ zyskają sławę". Sama instytucja została w roku 1857 częścią Uniwersytetu Kalkuckiego. Jej biblioteka, nazwana zresztą od imienia jednego z jej założycieli biblioteką Careya, posiada około 16000 , często niezwykle rzadkich woluminów. 
Sam Carey przybył do Indii w listopadzie roku 1793. Od początku swego pobytu w Indiach rozpoczął naukę języka bengalskiego ${ }^{104}$ i sanskrytu. Wkrótce oddał się też lekturze słynnego i kluczowego dla głębszego zrozumienia kultury indyjskiej eposu Mahabharata. W roku 1796 Carey w liście do Andrew Fullera napisał, co następuje:

Przeczytałem znaczącą część Mahabharaty, poematu epickiego napisanego w najpiękniejszym języku; poematu porównywalnego do Homera. Mahabharata jest podobna do Iliad $y$ i jest owocem geniuszu ludzkiego. Uważam, że jest to jedno z najdoskonalszych dzieł na świecie ${ }^{105}$.

Carey $z$ początku nie osiągnął wiele $w$ dziedzinie ewangelizacji. Był traktowany jako obcy, który chce naruszać coś tak niezwykle ważnego jak lokalną wiarę. W roku 1798, w liście do Johna Sutcliffe'a, napisał, iż prawie skończył tłumaczenie gramatyki i słownika sanskryckiego na język angielski. Niestety brakuje informacji na temat tego, co było podstawą jego tłumaczenia. Stwierdził także, iż równolegle pracuje nad własnym słownikiem sanskrycko-bengalsko-angielskim ${ }^{106}$. Słownik ten, owoc prawie 30 lat pracy, został ukończony w roku $1825^{107}$. Jego tytuł brzmiał $A$ Dictionary of the Bengalee Language, in which the

104 Już w roku 1801 opublikował gramatykę języka bengalskiego zatytułowaną $A$ Grammar of the Bengalee Language. Gramatyka ta była później kilkakrotnie, po każdorazowym poprawieniu i uzupełnieniu jej przez autora, wznawiana.

105 Cyt. za: J. Brockington, op. cit., s. 1 ( $I$ have read a considerable part of the Mahabharat, an epic Poem, written in most beautiful Language; and much upon a par with Homer, - and was it like his Iliad only considered as a great effort of human genius, I should think it one of the first productions in the world").

106 Ibidem, s. 2.

107 Ibidem, s. 4. 
words are traced to their origin, and their various meanings given. W roku 1807 Carey został profesorem sanskrytu i bengalskiego w College of Fort William, który w dziedzinie pracy wydawniczej współpracował ściśle z Serampore Press i funkcjonował do roku 1830. Już wcześniej, bo w roku 1804, powierzono mu także obowiązki nauczyciela języka marathi (marāthīi). Podczas jego profesury głównym panditem odpowiedzialnym za studia nad bengalskim i sanskrytem był bramin Mritjuńdżaja Widjalamkara (Mṛtyuńjaya Vidyālaṃkāra). On właśnie był nauczycielem Careya i pomagał mu w przygotowywaniu co najmniej kilku z jego publikacji ${ }^{108}$.

Carey w roku $1806^{109}$ opublikował gramatykę sanskrytu, do wydania której użyto drewnianych czcionek dewanagari. Wcześniej, bo w roku 1801, pisał w liście do Johna Rylanda:

[...] zostałem również wyznaczony na nauczyciela języka Sunscrit i mimo że nie mam jeszcze studentów, muszę się do tego przygotować. Dlatego właśnie piszę gramatykę tego języka, którą muszę również wydrukować, o ile zdołam. Być może uda mi się wydać również słownik, który zacząłem przygotowywać już kilka lat temu ${ }^{110}$.

Ten cytat wymownie świadczy o pionierskiej pracy Careya, i to zarówno w dziedzinie przekazywania informacji o samej gramatyce, jak i w próbach zdobywania słuchaczy chętnych do zgłębiania jej tajników. Argumentacja Careya pokazuje też, jakie motywy leżały

\footnotetext{
108 Ibidem.

109 Jej skrócona wersja ukazała się wcześniej, w roku 1804.

110 Cyt. za: ]. Brockington, op. cit., s. 3 ( ${ }_{n}[\ldots]$ I am also appointed teacher of the Sunscrit language; and though no students have yet entered in that class, yet I must prepare for it. I am therefore writing a grammar of that language, which I must also print, if I should be able to get through with it, and perhaps a dictionary, which I began some years ago").
} 
często u podstaw decyzji o pisaniu kolejnych gramatyk przez wielu mu współczesnych i tych, którzy robili to po nim. Z pewnością obieg informacji o istniejących gramatykach był bardzo niedoskonały. We wstępie do swojej gramatyki Carey pisze bowiem:

Ci w Europie, których gramatyka sanskrytu ciekawi, byli i są do tej pory wyłączeni $z$ możliwości jej studiowania ze względu na brak podstawowych książek, które mogliby zrozumieć; nawet w Indiach trudności są tak duże, że udaje się to tylko nielicznym [...]"'.

To może wyjaśniać, dlaczego w tym samym mniej więcej czasie powstawały prace, które niezbyt różniły się między sobą, zatem nie nowatorstwo ujęcia było podstawową przyczyną, dla której powstawały. Ostatecznie Carey dokończył swoje dzieło i zatytułował je A Grammar of the Sungskrit language, composed from the works of the most esteemed Hindoo Grammarians. To which are added exmples for the exercise of the student, and a complete list of dhatoos or roots. Pierwsze wydanie tej gramatyki składa się z trzech części, w których kolejno zostały opisane: alfabet, połączenia eufoniczne, odmiany rzeczowników, przymiotników i zaimków oraz koniugacja. W drugim wydaniu dodano rozdział 4, traktujący o złożeniach nominalnych oraz o rodzajach, a także rozdział 5, w którym można znaleźć informacje na temat składni oraz wybór ćwiczeń opartych na pierwszej części Bhagawata

111 W. Ca rey, A Grammar of the Sungskrit Language, composed from the works of the most esteemed Hindoo Grammarians. To which are added exmples for the exercise of the student, and a complete list of dhatoos or roots, Serampore (1804) 1806, Preface, s. I-II ("The curious in Europe have hitherto, been precluded from the study of the Sungskrit, through the want of elementary books in a language which they could understand; and, even in India, the difficulties have been so great, that few have attempted it $\left.[\ldots]^{n}\right)$. 
Purany. Do gramatyki dołączony został apendyks zawierający spis wybranych rdzeni czasownikowych (Dhatoos) ${ }^{112}$.

Carey jako swoje główne źródła wspomina przede wszystkim gramatyki Wopadewy, Kramadeśwary i Paniniego (Pāṇini) ${ }^{113}$. Jest oczywiste, że podobnie jak inni Europejczycy musiał w ich poznawaniu korzystać z pomocy lokalnych uczonych ${ }^{114}$. Poza samymi gramatykami Carey był także jednym z tych, którzy przyczynili się do dostępu do informacji na temat wielu sanskryckich dzieł literackich. J. J. Higginbotham pisze, iż uważa się, że Carey znał i mógł mówić w co najmniej siedmiu językach indyjskich, w tym w sanskrycie ${ }^{115}$. W roku 1804 on oraz Henry Thomas Colebrooke, który był autorem wstępu, wydali w Serampore książkę zatytułowaną Hitopadeśa, or Salutary Instruction, in the original Sanscrit zawierającą Hitopadeś̨̧ (Hitopadeśa) właśnie, fragment z Daśakumaraczarity (Daśakumāracarita) i z Bhartrihariego. Dla dobrego przygotowania samej tylko Hitopadeśi skolacjonowano sześć różnych manuskryptów. W 1806 roku Carey został jednogłośnie wybrany na członka Asiatic Society of Bengal. Towarzyszącą mu stale ideą było stopniowe wydawanie głównych dzieł sanskryckich, w szczególności tekstów uważanych przez Hindusów za święte.

Misjonarze baptyści niewątpliwie sprawili, iż można mówić o zjawisku "renesansu seramporskiego" jako o analogicznym do znanego

\section{Skr. "dhātu”.}

113 We wstępie dodaje jeszcze inne, mniej ważne „[...] Wikruma-dikshitu, Doorga-dasu, and Goee-chundra" (por. W. Ca rey, op. cit., s. IV-V).

114 Wspomina o tym we wstępie do swojej gramatyki, gdzie pisze expressis verbis, że pomagali mu indyjscy pandici. Byli to wspominany już Mritjundża Widjalamkara oraz Ramanatha Wacaspati. Carey pisze bowiem, że jego pomocnikami byli „highly esteemed colleague Mr. Marshman, and from Mrtyoonjuyu Vidyalunkuru, and Rama-nathu Vasusputi, the first and second Pundits in the College of Fort William, who have been always ready to contribute to this work" (por. W. Carey, op. cit.).

115 J. J. Higginbotham, op. cit., s. 55-57. 
powszechnie "renesansu bengalskiego". Ich działalność, poza ewangelizacją, dotyczyła też głębokich reform społecznych, wpływali na osłabianie czy nawet likwidację systemu warnowego, rozpowszechniali edukację wśród miejscowej ludności. Europie zaś przynieśli niezwykle dużo kompetentnych informacji na temat Indii i występujących tam języków, w tym sanskrytu. Careyowi udało się skutecznie przekonać miejscowych uczonych do podzielenia się z nim informacjami na temat gramatycznych reguł sanskrytu, co w konsekwencji umożliwiło dostęp do najświętszych indyjskich ksiąg. Były to tajemnice ciągle jeszcze przez wielu miejscowych panditów ściśle strzeżone nie tylko przed Europejczykami, ale także przed indyjską ludnością pochodzącą z niższych warstw.

\section{James Robert Ballantyne, A Catechism of Sanskrit Grammar}

Również w Serampore działał James Robert Ballantyne (1813-1864) i mimo że głównym obszarem jego zainteresowań była indyjska filozofia (a może właśnie dlatego) ${ }^{116}$, także i on pokusił się o napisanie własnych podręczników do nauki sanskrytu. Pierwszym z nich było bardzo krótkie, bo dwudziestodwustronicowe opracowanie zatytułowane $A$ catechism of Sanskrit grammar ${ }^{117}$. Mimo że, choćby z racji swojej krótkości, gramatyka ta nie obejmowała nawet niewielkiej części zagadnień gramatycznych sanskrytu, sama jej forma była niewątpliwie nowatorska. Ballantyne napisał ją bowiem $w$ formie dialogu odbywa-

116 James R. Ballantyne jest autorem wielu książek z tej dziedziny, m.in. tej wydanej w Londynie w roku 1859 i zatytułowanej Christianity Contrasted with Hindu Philosophy.

117 J. R. Balla nt y ne, $A$ Catechism of Sanskrit Grammar by James R. Ballantyne of the Scottish Naval and Military Academy, Edinburgh 1843. 
jącego się między nauczycielem i uczniem pytającym o poszczególne zagadnienia gramatyczne. Ze względu na sposób przedstawienia informacji gramatycznych można uznać ją za rodzaj prototypu gramatyk sanskrytu, które przyjęły formę samouczka ${ }^{118}$. Książeczka składała się z kilku części zatytułowanych odpowiednio: On the Alphabet, Sandhi, On the Nouns, The Verbs, Compound Words. Przykłady w sanskrycie były podawane w transkrypcji. Pierwsze dwa

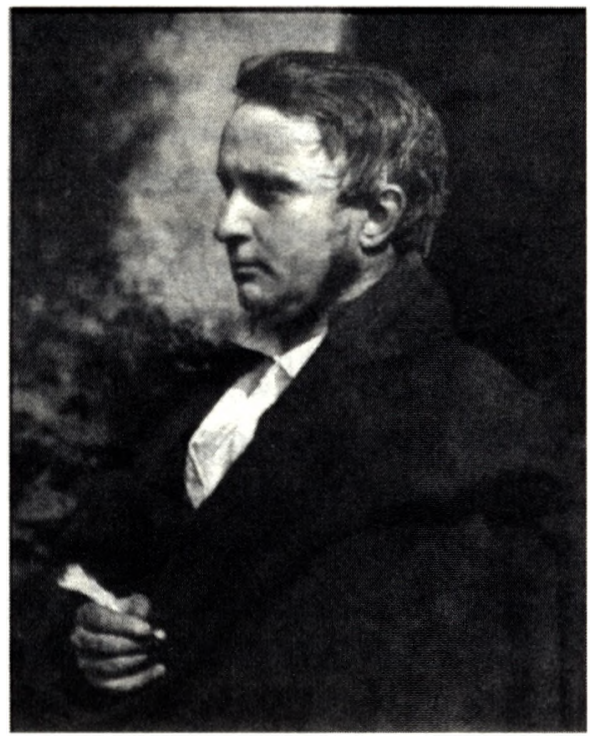

9. James Robert Ballantyne pytania i dwie odpowiedzi rozdziału 1 brzmią w sposób następujący:

Qu 1. Which are the hard or surd letters of the Devanāgari alphabet? A. The hard or surd letters are the two first of the guttural, palatal, cerebral, dental, and labial classes; and also the sibilants.

Q 2. Repeat them.

'ka' 'kha,' 'gha' cha,' 'ta' 'tha,' 'ta' 'tha,' 'pa' 'pha,' 'sa' 'sha'.

Rozdział 2 rozpoczyna się od bardzo ogólnego pytania, na które pada najbardziej zwięzła z możliwych odpowiedź:

118 Obecnie forma ta jest bardzo popularna. Jednym z często używanych, wielokrotnie wznawianych $\mathrm{i}$ bardzo popularnych samouczków jest ten napisany przez Michaela Coulsona (por. M. Coulson, (Teach Yourself) Sanskrit. An Introduction to the Classical Language, London 1976). 
Qu 10. What does the term 'sandhi' signify?

Conjunction.

Jej dookreślenie następuje w kolejnej wymianie zdań:

Qu. 11. Of what does this department of Sanskrit Grammar treat? Of the euphonic changes which take place in the last letter of a word, or in the first letter of the word which follows, or in both.

Cały ten rozdział składa się z 26 zestawów pytań i odpowiedzi. Są one podzielone na pięć części. Część pierwsza zatytułowana jest $O n$ the conjunction of Vowels, druga On Conjunction of Consonants, trzecia Mutation of Sibilantes, czwarta Anusvära i wreszcie piąta Visarga.

Część zatytułowana On the Nouns ponownie rozpoczyna się pytaniami natury bardzo ogólnej.

Qu. 26. In what form does the noun appear in the Sanskrit Dictionary? - pyta potencjalny uczeń.

A. In the 'crude form'.

Ta właśnie lakoniczna fraza stanowi całą odpowiedź. Ponieważ jednak nadal nie jest ona jasna, student dopytuje:

Is the 'crude form' one of the cases of the noun?

Nauczyciel odpowiada:

No; but it frequently resembles the vocative case.

Ta konwersacja pokazuje, iż student musiał być choćby wstępnie przygotowany. Tylko wtedy mógł bowiem zrozumieć odpowiedzi na swoje pytania. Pozostałą treść tej części stanowią podane wybiórczo paradygmaty (np. zestaw końcówek przypadków czy deklinacja wy- 
branych rzeczowników). To przedstawienie jest niewątpliwie bardzo ograniczone, nie pokazano bowiem w jego ramach całej różnorodności możliwych paradygmatów rzeczownikowych. Ta sama uwaga dotyczy przedstawienia „Pronouns and Pronominals”, jak nazywa je Ballantyne. Podaje jedynie paradygmaty odmian zaimków osobowych wszystkich trzech rodzajów, opatrując je uwagą, iż odmiany te są bardzo nieregularne. W części kolejnej koncentruje się na kategorii verbum. Można tu znaleźć całkiem sporo błędów, co świadczy o tym, iż jego znajomość gramatyki sanskrytu była niedoskonała. Ballantyne używa w odniesieniu do sanskrytu słów pełnych emocji, takich jak np. „formidable”, „cudowny". Porównuje go, choć bez przytaczania dowodów, do greki i łaciny. Co ciekawe, Ballantyne był także autorem tłumaczenia na język angielski i krytycznego opracowania jednej z ważnych gramatyk indyjskich. Swoją pracę, zatytułowaną The Laghukaumudī. A Sanskrit Grammar by Varadarāja. With an English Version, Commentary and References wydał w Benares w roku 1849. W późniejszym czasie napisał kolejną gramatykę w języku angielskim. Jej tytuł brzmiał First lessons in Sanskrit grammar, with an introduction to the Hitopadeśa. Została ona wydana w roku 1850 lub 1851 w Mirzapore. Co ciekawe, gramatyka ta była potem kilkakrotnie wznawiana, stając się niewątpliwie jednym z ważniejszych źródeł, z którego Europejczycy, w szczególności ci pracujący w Indiach, czerpali swoją wiedzę o sanskrycie ${ }^{119}$. Wiedza ta była im niewątpliwie niezwykle potrzebna. Już wtedy zdawano sobie sprawę z tego, że znajomość sanskrytu jest jednym z najważniejszych kluczy do poznawania kultury indyjskiej, do kontaktowania się z miejscowymi elitami. Niestety, nierzadko znajomość tę wykorzystywano do prób sprawowania "rządu dusz".

Jedną z postaci ważnych w dziele poznawania tekstów sanskryckich, do których rozumienia niezbędna była znajomość gramatyki, był in-

119 Wyd. 2 1862; wyd. 3 1865; wyd. 4 1885; reprint 1941. 
dolog John Muir (1810-1882). To właśnie on, zresztą współpracujący ściśle m.in. $z$ Williamem Careyem, jest tym, który zgromadził wybrane teksty sanskryckie odnoszące się do najrozmaitszych zagadnień dotyczących kultury indyjskiej oraz doprowadził do wydania ich w postaci dzieła składającego się na pięć obszernych tomów. Poszczególne woluminy ukazywały się stopniowo w latach 1858-1872. Dzieło zatytułowane było Original Sanskrit Texts on the Origin and History of the Indian People (Oryginalne teksty sanskryckie dotyczące pochodzenia i historii ludności indyjskiej).

\section{Charles Wilkins, A Grammar of the Sanskrita Language}

Pierwszym Anglikiem, który posiadł znajomość sanskrytu w stopniu bardzo dobrym, był Charles Wilkins (1749-1836) ${ }^{120}$. Zachęcony do tego przez Warrena Hastingsa, najprawdopodobniej pobierał nauki dotyczące sanskrytu od uczonych panditów. Imię jednego z jego nauczycieli podaje się jako Kallyanath. Pierwszym owocem jego studiów było opublikowanie w roku 1785 angielskiego tłumaczenia Bhagawadgity (Bhagavadgīāa), jednego z najważniejszych tekstów kultury indyjskiej, poematu filozoficznego włączonego w Mahabharatę. Bhagawadgita w wersji Wilkinsa była pierwszym dziełem będącym bezpośrednim tłumaczeniem z sanskrytu, które pojawiło się w Europie ${ }^{121}$.

120 Wilkins opanował też język perski i bengalski, o czym wiadomo, ponieważ są dane, $z$ których wynika, że pracował jako tłumacz z tych właśnie języków. Świadczy o tym także i to, że zaprojektował jako pierwszy potrzebne do druku tak znaki bengalskie, jak i perskie (por. Grammatica Grandonica..., s. 231).

121 Bhagawadgita była od tej pory i jest nadal tłumaczona na ogromną liczbę języków. W tym na większość języków europejskich. W Polsce także posiadamy kilkanaście przekładów oraz tłumaczeń tego dzieła opatrzonych 
W 1787 Wilkins wydał swoją angielską wersję zbioru popularnych bajek i zatytułował ją Gidopadesha. Chodzi o znaną z wielu późniejszych wydań i tłumaczeń Hitopadeś̨ (Hitopadeśa). Po raz wtóry to właśnie

zresztą często mniej lub bardziej szczegółowymi objaśnieniami. Wielu z indologów, pomimo istnienia już tylu polskich wersji Bhagawadgity, uważa, że musi zaproponować także swoją jej interpretację. Pokazuje to jednocześnie jak ogromne pole daje sanskryt do różnych odczytań, wydawałoby się, tego samego tekstu. Osobą, która od bardzo wielu lat zajmuje się w Polsce Bhagawadgitq, jest Joanna Sachse. To jej tłumaczenie zatytułowane Bhagawadgita, czyli Pieśn Pana jest zaopatrzone w bardzo wyczerpujące przypisy i komentarze. To właśnie ta tłumaczka napisała także osobną książkę poświęconą analizie wybranych problemów interpretacyjnych (J. Sachse, Ze studiów nad Bhagawadgitq, Wrocław 1988). To wreszcie ona, po 30 latach, dokonała kolejnego odczytania tego tekstu. Zostało ono wydane pt. Bhagawadgita, czyli Pieśn Czcigodnego we Wrocławiu w roku 2019. Warto tu wspomnieć jeszcze o kilku tłumaczeniach Bhagawadgity na język polski dokonanych przez indologów. Pierwszego polskiego tłumaczenia całości tego poematu na język polski dokonał S. F. Michalski-lwieński: Bhagawadgita, czyli Pieśn o Bogu. Poemat filozoficzny indyjski. Od swego pierwszego wydania, które nastąpiło w roku 1910 , było ono kilkakrotnie wznawiane $(1921,1927)$. Kolejnym, szczególnym tłumaczeniem, uważanym przez niektórych za tłumaczenie "natchnione", jest przekład autorstwa Wandy Dynowskiej znanej jako Umadewi, który po raz pierwszy ukazał się w roku 1947, by potem zostać trzykrotnie wznowionym (1956; 1957; 1972). Ponieważ Wanda Dynowska przez wiele lat przebywała $w$ Indiach i miała bardzo dobre relacje $z$ miejscowymi uczonymi, uważa się, że byli oni jej doradcami w zrozumieniu tego właśnie (i nie tylko tego) dzieła. Ponadto Dynowska studiowała sanskryt na uniwersytetach w Krakowie, Lozannie i Paryżu, dlatego pojawiające się od czasu do czasu oskarżenia o jej nieznajomość języka oryginału wydają się bezzasadne. Wielu uważa, że to właśnie ona zrozumiała "ducha" sanskrytu. W roku 1995 pojawiło się jedno z kolejnych tłumaczeń - krakowskiej indolożki Marty Kudelskiej zatytułowane Bhagawad Gita, w 2002 z kolei - Anny Rucińskiej Bhagawadgita. Święta Pieśn Pana. Szerzej o niektórych z przekładów pisze A. Łozowska w zamieszczonym w „Przeglądzie Orientalistycznym" artykule Bhagawadgita w polskich przekładach (A. Łozowska, Bhagawadgita 
Hitopadeśa była jednym z pierwszych wybieranych do tłumaczenia i udostępniania publiczności europejskiej tekstów. Natomiast w 1795 roku Wilkins wzbogacił wybór bezpośrednich tłumaczeń z sanskrytu na język angielski o jeszcze jeden tekst, mianowicie wersję opowieści o Śakuntali (Śakuntalā), pochodzącą z pierwszej księgi Mahabhara$t y^{122}$. Jego dziełem była takize gramatyka sanskrytu $A$ Grammar of the Sanskrita Language, która ukazała się w Londynie w roku $1808^{123}$. W przedmowie do swojej gramatyki Wilkins wspomina o innych badaczach zajmujących się w tym czasie podobnymi obszarami wiedzy i zachęcających go do zajęcia się tymi właśnie tematami. I tak, pisze o tłumaczącym rozmaite ważne sanskryckie teksty Nathanielu Halhedzie (1751-1830) ${ }^{124}$, o Williamie Jonesie i o Henrym Thomasie Colebrooke'u. W odniesieniu do Colebrooke'a pisze o jego wydanym w siódmym tomie "Asiatic Research" tekście dotyczącym sanskrytu

w polskich przekładach, "Przegląd Orientalistyczny" 2008, vol. 226-227, nr 3-4, s. 137-152). Obecnie także nad przekładami Bhagawadgit $y$ w ujęciu porównawczym pracują polscy indologowie $w$ ramach projektu internetowego zamieszczonego pod adresem www.bhagavadgita.eu.

122 The story of Dooshwanta and Sakoontala. Translated from the Mahabharata, a poem in the Sanskreet language. By Charles Wilkins, Esq. Originally published in the Oriental Repertory vol. II by Dalrymple 1794. Wydana też w formie reprintu w roku 2010 przez Gale ECCO, Print Editions.

${ }_{123}$ A Grammar of the Sanskrita Language by Charles Wilkins, London 1808. Gramatyka ta była popularna, ponieważ była jedną z niewielu dostępnych w owym czasie w Europie, jako że te opublikowane w Indiach, w Kalkucie ze względu na wojny napoleońskie nie docierały wtedy do Europy.

124 Nathaniel Brassey Halhed (1751-1830) był brytyjskim orientalistą, który pobierał nauki u Williama Jonesa. W 1776 roku wydano w jego tłumaczeniu na język angielski pracę zatytułowaną Gentoo Code. W 1778 roku opublikował gramatykę języka bengalskiego. Bardzo dużo tłumaczył, ale wiele z tekstów nie zostało opublikowanych. Jego kolekcja manuskryptów została zakupiona przez British Museum, a nieskończone tłumaczenie Mahabharaty znajduje się w zbiorach Asiatic Society of Bengal. 
i prakrytów: "Miłośnik nauki, archiwista, historyk, moralista, poeta i człowiek o wielkim poczuciu smaku. To właśnie on jest w stanie znaleźć w tekstach sanskryckich niewyczerpaną ilość wiadomości, ale też rozrywki" ${ }^{125}$, wskazując tym samym na korzyści najrozmaitszej natury, które może przynieść znajomość sanskrytu. Pisze także, iż biegłość w sanskrycie powinna sprawić, że znacznie łatwiejsze

G R A M M A R

SANSKRITTA LANGUAGE

e.

CIINRIES WII.KINS, LID J.R.S.

अयुं गटित्र पोलें प्रमारेन जमेन या ।

वाचा मया द्यावकः मध मंख्यापयणु नन $n$



1806.

10. Charles Wilkins, $A$ Grammar of the Sanskrita Language, strona tytułowa

stanie się opanowa-

nie i innych indyjskich języków ${ }^{126}$. Wilkinsowi nie były znane gramatyki sanskrytu napisane wcześniej przez innych autorów, dlatego

125 Ch. Wilkins, $A$ Grammar of Sanskrit Language, Introduction, s. X (" The lover of science, the antiquary, the historian, the moralist, the poet, and the man of taste, will obtain in Sanskrit books an inexhaustible fund of information and amusement $\left.{ }^{\top}\right)$.

126 Ibidem. 
właśnie postanowił sam podjąć się tego dzieła. Udało mu się znaleźć dobrego nauczyciela, pandita, który był skłonny podzielić się z nim swoją znajomością języka. Pisał:

Miałem szczęście spotkać pandita, który był wystarczająco otwarty na kontakt, a zarazem wystarczająco biegły w sztuce znajomości gramatyki sankrytu, by mnie wyuczyć. Ale ponieważ w tym czasie (a z pewnością do niedawna) nie było podstawowych książek z tej dziedziny w żadnym zrozumiałym języku, postanowiłem taką właśnie napisać. Tworzyłem zatem, z pomocą mojego mistrza, najpierw wyciągi z gramatyk, a potem dopiero ich tłumaczenia. Były one napisane w sanskrycie, języku, którego się uczyłem ${ }^{127}$.

Pokazuje to, jakiej metody używał Wilkins, by opanować gramatykę sanskrytu. $Z$ pewnością nie była to łatwa droga. Jako podstawę wykorzystał popularne gramatyki Saraswati Prakrija (Sārasvatīprakriyā), której autorem był Anubhuti Swarupaczarja (Anubhūti Svarupācārya), Mugdhabodhę (Mugdhabodha) Wopadewy (Vopadeva) i Ratna Malę (Ratna-mālā) Puruszottamy (Purușottama). Dodatkowo, studiował później także sutry (sūtra) Paniniego (Pāṇini), Siddhantakaumudi (Siddhāntakaumudī) Bhattodżikszity (Bhattojidīkșita), Siddhanta Czandrikę (Siddhānta Chandrikā) Ramachandraśrama (Rāmachandrāśrama) oraz inne jeszcze teksty, których nie wymienia z nazwy. Przywiózł także ze sobą do Anglii niektóre z komentarzy ${ }^{128}$.

127 Ibidem, s. XI [ $\mathrm{n}$ was fortunate to find a pandit of a liberal mind, sufficiently learned to assist me in the pursuit; but as at that time (and indeed not till very lately) there did not exist, in any language I understood, any elementary books, I was compelled to form such for myself as I proceeded, till, with the assistance of my master, I was able to make extracts, and at length entire translations of grammars, wholly composed in the idiom I was studying"]. ${ }^{128}$ Ibidem, s. XI-XII. 
Był to niewątpliwie imponujący zestaw źródeł. Wilkins podczas pisania i przygotowań do drukowania swojej gramatyki przeżył dramatyczne chwile, w jego domu bowiem wybuchł pożar i strawił część zapisków oraz przygotowane samodzielnie przez niego z ogromnym mozołem czcionki dewanagari. Na szczęście ocalały przywiezione $z$ Indii manuskrypty. Sama gramatyka ma charakter opisowy i składa się z 11 rozdziałów: 1 . Of the elements. Ten rozdział przedstawia informacje na temat alfabetu. 2. Ortography. Ten opisuje możliwe zmiany samogłosek i spółgłosek następujące pod wpływem określonego sąsiedztwa. 3. Declension of nouns. Wilkins dzieli ten rozdział na opis ośmiu deklinacji. Poszczególne grupy wyróżnia ze względu na zakończenia tematów, rozróżniając wyraźnie tematy samogłoskowe od spółgłoskowych. 4. Declension of pronouns and pronominals. Rozdział dotyczy przede wszystkim zaimków 5. Conjugation of verbs. Tutaj Wilkins podaje wiadomości na temat czasowników, stron, form odmiennych i nieodmiennych, liczb i osób, trybów i czasów, końcówek i 10 odrębnych koniugacji. Pisze także szczegółowo o niektórych formach poszczególnych czasów, które określa jako drugie i trzecie praeteritum, pierwsze i drugie futurum. Podaje informacje o precativie, conditionalu, o koniugacjach pochodnych, o passivum i formach nieodmiennych. Objaśnia, jak tworzyć zdania przeczące. Dodaje jeszcze kilka uwag natury ogólnej oraz omawia temat prepozycji. 6. On the formation of participles and participial nouns. Tutaj Wilkins skupia się na temacie participiów, podając ich możliwy podział, przykłady form typowych i nietypowych oraz ich odmianę. Pisze także o formach nieodmiennych. 7. On the formation of derivative words. Podaje informacje dotyczące patronimików oraz rozmaitych przymiotników pochodnych. Podaje wiadomości o stopniowaniu, o liczebni$\mathrm{kach} \mathrm{i}$ innych jeszcze formach mieszanych. 8. Indeclinable words. Rozdział ten zawiera alfabetyczną listę form nieodmiennych, a także wybrane informacje na temat niektórych $\mathrm{z}$ nich tworzonych 
$z$ pomocą afiksów. 9. On the formation of compound words. Tu Wilkins przedstawia złożenia, opisując je w następującej kolejności: awjajibhawa, tatpurusza, dwandwa, dwigu, karmadharaja. Zamyka rozdział uwagami natury ogólnej dotyczącymi reguł ich tworzenia. 10. Genders of nouns. Rozdział dotyczy rodzajów. Opisane są kolejno formy masculinum, femininum i neutrum. 11. Syntax. Wreszcie w ostatnim rozdziale Wilkins pisze ogólnie o składni sanskryckiej, o zastosowaniu ośmiu przypadków (bo tyle właśnie ich wymienia) oraz o połączeniach wybranych rzeczowników z innymi słowami. Pisze także o zaimkach, czasownikach i participiach i podaje wiadomości odnośnie do ich użycia. Już w spisie treści autor uży wa alfabetu dewanagari, by potem często uzupełniać angielski tekst oryginalnym zapisem. Już w pierwszych zdaniach wyraża swój zachwyt doskonałością sanskrytu, odwołując się do języka używanego w Śakuntali Kalidasy ${ }^{129}$. Dzięki tej krótkiej uwadze można stwierdzić, iż metodą, której uży wał Wilkins podczas przygotowywania swojej gramatyki, była nie tylko praca z panditem, podczas której ten przekazywał mu ściśle gramatyczne wiadomości oparte na gramatykach indyjskich, ale także prawdopodobnie samodzielna lektura tekstów literackich. To dopiero osadzenie gramatyki w literaturze było, jego zdaniem, pełnym sposobem na poznawanie nieznanego języka. Jak opisano powyżej, w rozdziałach, podzielonych na podrozdziały poświęcone poszczególnym zagadnieniom gramatycznym, Wilkins stopniowo omawia wszystkie najważniejsze zagadnienia gramatyczne. Relatywnie często włącza do swojej gramatyki fragmenty tekstów sanskryckich tak w oryginalnym zapisie, jak i w transkrypcji, podając jednocześnie proponowane przez siebie tłumaczenia ${ }^{130}$. Często także poza formami typowymi krótko

130 Np. w rozdziale 1 są to fragmenty pochodzące ze zbioru bajek Hitopadeśa. 
omawia wyjątki ${ }^{131}$. Na stronie 23 podaje tabelę, dzięki której uczący się może w łatwiejszy sposób opanować reguły sandhi ${ }^{132}$. W przykładach, które podaje celem zilustrowania zagadnień gramatycznych, wprowadza postaci ważne dla literatury staroindyjskiej ${ }^{133}$. Rozdział poświęcony rzeczownikom $i$ ich odmianie zawiera tak wiadomości ogólne, jak i dużo przykładów ${ }^{134}$. Wilkins nie podaje nazw przypadków, ale oznacza je liczbami - pisze "case $1^{n}$ czy "case $2^{n}$, mając na uwadze mianownik i biernik. Jest to zgodne $z$ tradycją indyjską, w której nazwy przypadków były nienacechowane, niejako "przejrzyste", były po prostu liczebnikami porządkowymi. Wołacz podawany jest na końcu paradygmatu. W rozdziale 5, najobszerniejszym, opisując czasowniki, dzieli je na trzy rodzaje, które określa jako „primitives", "derivatives" i "nominals". Rozdział 6 poświęca tworzeniu participiów, czyli imiesłowów, wskazując na ogromną wagę umiejętności rozpoznawania tychże. Formy derywowane są przedmiotem rozdziału kolejnego. Wilkins omawia tu, podobnie jak w innych rozdziałach, zarówno reguły ogólne, jak i poszczególne, wchodzące w skład tego tematu, zagadnienia w sposób bardzo przejrzysty i podając wiele przykładów. W rozdziale 8 skupia się na formach nieodmiennych. Zawartość tego rozdziału jest absolutnie porównywalna

131 Np. w rozdziale 2 dotyczą one nietypowej odmiany rzeczowników.

132 Ten typ tabeli będzie zresztą zamieszczany w wielu innych, także tych powstających współcześnie, gramatykach sanskrytu.

133 Np. Ramę syna Daśarathy, Sitę czy Lakszmana, głównych bohaterów eposu Ramajana albo Judhiszthirę, jednego z pięciu braci Pandawów, głównych bohaterów Mahabharaty, czy jego brata Ardżunę (Ch. Wilkins, op. cit., s. 34,621$)$.

134 Identyczne przykłady powtarzają się zresztą potem w wielu innych europejskich gramatykach sanskrytu (np. w gramatyce autorstwa Andrzeja Gawrońskiego, jednego z najwybitniejszych polskich indologów i językoznawców (A. Gaw roński, Podręcznik sanskryıu. Gramaıyka, wypisy, objasnienia, stownik, wyd. 1 1932; wyd. 2 1985; wyd. 3 poprawione 2004). 
ze współczesnymi, zawartymi w najnowszych, napisanych w wieku XX gramatykach, opisami. Dodatkowo, co jest wielką zaletą tej gramatyki, Wilkins przedstawia poszczególne formy nieodmienne także w postaci zestawienia alfabetycznego, w którym poza daną formą, zapisaną $w$ alfabecie dewanagari, podaje jej tłumaczenie na język angielski. Rozdział 9 dotyczy złożeń, zagadnienia, którego znajomość stanowi jeden z kluczy do zrozumienia sanskrytu. Swoje omówienie tego tematu Wilkins rozpoczyna od złożeń typu awjajibhawa. Jest to niezwykle szczegółowe i dobrze rozplanowane przedstawienie tego tematu. Kolejnymi omawianymi przez Wilkinsa złożeniami są złożenia typu tatpurusza. Po raz kolejny autor wykazuje się doskonałą znajomością tematu i umiejętnością świetnego, uporządkowanego bardzo logicznie przedstawienia. Po podrozdziale dotyczącym złożeń typu tatpurusza następuje ten, w którym Wilkins omawia złożenia typu dwandwa. I tutaj wzbudza podziw sposób i jakość przedstawienia. Całość zagadnienia autor zawiera w 25 dobrze skonstruowanych mniejszych fragmentach, obejmujących wyróżnione przez siebie pomniejsze tematy. Kolejnym zagadnieniem są złożenia typu dwigu. Rozdział ten, mimo że relatywnie krótszy, ponownie pokazuje, jak w sposób zwięzły można zapoznać potencjalnego odbiorcę, często osobę, która chce samodzielnie zgłębiać tajniki gramatyki sanskrytu, z tymi jakże często trudnymi zagadnieniami. Złożenia typu bahuwrihi są opisane jako kolejne. I tutaj Wilkins materiał teoretyczny zaopatrza ogromną ilością przykładów. Jest oczywiste, iż umiejętność takiego praktycznego sposobu przedstawienia tematu musi wynikać z ogromnego oczytania. Złożenia typu karmadharaya to kolejny obszar wiedzy gramatycznej, z którą można się zapoznać dzięki lekturze gramatyki Wilkinsa. Tym razem szczegółowe przykłady poprzedzają sformułowane przez autora na koniec tego podrozdziału reguły ogólne. Rozdział kończą zarówno uwagi natury ogólnej, jak i informacje podawane przez autora jako uzupełniające. 
Wreszcie rozdział 10 to część poświęcona zagadnieniu rodzajów rzeczowników, z podziałem na formy męskie, żeńskie i nijakie. Co ciekawe Wilkins rozpoczyna ten rozdział kilkoma paragrafami poświęconymi konkretnymi uwagami dotyczącymi tego, które z wyrazów czy może raczej kategorii wyrazów przyjmują w sanskrycie formy męskie ${ }^{135}$. Podobnie jak w przypadku słów rodzaju męskiego i żeńskiego Wilkins rozpoczyna tę część swojej prezentacji od podania wyrazów, które zawsze, jego zdaniem, posiadają formę rodzaju nijakiego $^{136}$. Wreszcie rozdział 11 , ostatni, Wilkins poświęca składni. To jeden $z$ najtrudniejszych tematów w gramatyce sanskrytu, o czym

135 Wilkins pisze m.in., że tak jest, gdy słowa oznaczają np. poszczególne nieba, księżyc, planety, a w szczególności gwiazdy. Podobnie dzieje się, gdy słowa te dotyczą takich pojęć, jak góry, chmury, powietrze, ogień, oceany. Również formę męską przybiera wyraz drzewo i jego synonimy czy nazwy różnych rodzajów drzew, nazwy wielu rodzajów broni. Wróg, ręka, stopa, kolano i wiele innych części ciała takich jak policzek, warga, ząb, ramię, gardło, włosy na głowie, paznokieć czy pierś. Czy są to wyliczenia znaczące? Wilkins nie starał się podawać reguł ogólnych, które mogłyby pomóc w zapamiętaniu przypisy wanych poszczególnym wyrazom rodzajów. Po prostu zamieścił na początku tego rozdziału takie wyliczenia. W przypadku form żeńskich jego objaśnienia są natury syntetycznej, tylko od czasu do czasu podaje konkretne, pojedyncze przykłady. Pisze np., że wszystkie słowa oznaczające błyskawicę czy ziemię są co do rodzaju żeńskie. Pytaniem, które można tu postawić, jest to, czy tak kategoryczne tezy Wilkins stawiał, opierając się na przekonaniu o swojej aż tak doskonałej znajomości słownictwa, czy może jego nauczyciel przekazywał mu takie informacje. Czy rzeczywiście, szczególnie w przypadku sanskrytu, który jest językiem tak bogatym i obfitym $w$ synonimy, można tak kategoryczne sądy, przynajmniej gdy chodzi o słownictwo, prezentować?

${ }_{130}$ Tu można odnaleźć sprzeczność czy niedokładność, o ile bowiem jako przykłady wyrazów rodzaju męskiego Wilkins podawał słowa na oznaczenie różnych rodzajów nieba (używając na ich określenie angielskiego słowa heavens), tu pisze, że określenia stosowane względem różnych rodzajów przestrzeni niebiańskich, które są widoczne (visible heavens), są rodzaju nijakiego. 
wie każdy, kto starał się z nią zapoznać, korzystając z dostępnych źródeł. Metoda zastosowana przez Wilkinsa polega w niektórych przypadkach na tym, iż każdorazowo po przedstawieniu krótkiego objaśnienia teoretycznego podaje fragment tekstu oryginalnego w alfabecie dewanagari i jego tłumaczenie na język angielski. Ponad poszczególnymi wyrazami, zarówno w tekście oryginalnym, jak i w tłumaczeniu, umieszcza liczby, pokazując, w jakim porządku należy je analizować. $W$ innych podaje tekst $w$ oryginale i potem tłumaczenie z objaśnieniami. Do tekstu gramatyki dodana jest licząca aż sześć stron errata. Taka jej obszerność wskazuje na stopień trudności, który towarzyszył drukowaniu gramatyk w tamtych czasach. Pokazuje też, jak precyzyjny starał się być autor nawet w korekcie, podczas której sprawdzał najdrobniejsze szczegóły swojej książki. Całość gramatyki Charlesa Wilkinsa liczy 656 stron. Jest to dzieło niewątpliwie niezwykle obszerne. Tym niemniej dzięki swojej konstrukcji, szczegółowości, a zarazem dokonywanym często bardzo przenikliwym syntezom, podsumowaniom, jasnemu wyłożeniu części teoretycznych i zaopatrzeniu w ogromną ilość przykładów jest niewątpliwie doskonałym wprowadzeniem w świat sanskrytu. Sanskrytu rozumianego nie tylko przez pryzmat gramatyki języka, ale także szczegółów kulturowych najrozmaitszej natury, od zapoznawania odbiorcy $z$ bohaterami utworów literackich, przez informacje natury czy to geograficznej (np. podawanie w przykładach nazw miejsc, rzek etc.), czy mitologicznej. Wilkins kończy swoje dzieło krótkim słowem „FINIS". Czytelnikowi nasuwa się tu jednoznacznie skojarzenie $z$ dłuższym stwierdzeniem „FINIS CORONAT OPUS".

Ważną, choć nie bezpośrednio w dziedzinie poznawania gramatyki sanskrytu, osobą był wspominany już wcześniej William Jones (1746-1794), prawnik, który przybył do Indii w roku 1783, by objąć stanowisko głównego sędziego w Fort William. Jones interesował się Orientem znacznie wcześniej. Jako że był niezwykle utalentowany 
językowo, już przed przyjazdem do Indii posiadł znajomość niektórych z języków orientalnych, w szczególności języka arabskiego i perskiego, a ponieważ zajmowała go orientalna poezja, przetłumaczył jej fragmenty pochodzące właśnie $z$ tych dwóch języków. Po przyjeździe do Indii zainteresował się wkrótce tak literaturą, jak i sanskrytem. Przed upływem roku założył Asiatick Society (Towarzystwo Azjatyckie) ${ }^{137}$, które stało się z czasem jednym z bardzo ważnych

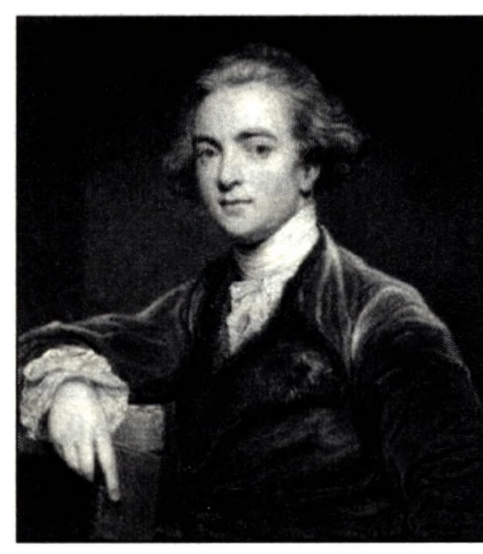

11. William Jones miejsc spotkań, na których wymieniano informacje dotyczące szeroko pojętej kultury indyjskiej, gdzie odbywały się dyskusje i prowadzono rozważania mające na celu lepsze jej poznanie. To właśnie w ramach prac Asiatic Society of Bengal ukazywały się liczne czasopisma oraz przygotowywane na poziomie naukowym wydania rozmaitych tekstów indyjskich ${ }^{138}$. Już na pierwszym posiedzeniu Towarzystwa Jones ogłosił, iż jednym z głównych jego celów będzie zdobywanie i pogłębianie wiedzy o języku starożytnych Indii, sanskrycie. Uważał, że to właśnie w sanskrycie zostały zapisane bardzo ważne dzieła kultury indyjskiej i jego znajomość będzie bardzo użyteczna, a na pewno uchroni od zdobywania niewystarczającej i niedoskonałej wiedzy pochodzącej ze źródeł pośrednich ${ }^{139}$. Jones, jako osoba zainteresowana prawem,

137 Znanego później jako Asiatic Society of Bengal.

138 Od roku 1788 ukazy wało się „Asiatick Researches", które do tej pory jest ważnym źródłem informacji.

139 Por. F. Edgerton, op. cit., s. 4. 
ale także literaturą, już w roku $1789^{140}$ opublikował zatytułowane Sacontala; or, the fatal ring: an Indian drama by Calidas tłumaczenie dramatu Śakuntala autorstwa Kalidasy ${ }^{141}$. Mimo że jego tłumaczenie zostało napisane prozą, czyli odbiegało w tym względzie od oryginału, najprawdopodobniej przede wszystkim ze względu na duże zainteresowanie Orientem, ale także ze względu na jakość angielszczyzny przekładu szybko zyskało zainteresowanie w Europie ${ }^{142}$. Już w roku 1791 zostało przetłumaczone przez Georga Fostera $(1754-1794)^{143}$ na

140 Wyd. 1 Calcutta 1789 (wydane ponownie w Londynie w latach 1790 i 1792; w Edynburgu w roku 1796. Potem także w latach 1799, 1807 i 1870; London: Charlton Tucker).

141 Polskie tłumaczenie tego dramatu zostało dokonane przez Stanisława Schayera i wydane po raz pierwszy w roku 1923 pt. Śakuntala, czyli pierścień fatalny (Śakuntala, czyli pierśsień fatalny. Dramat heroiczny w siedmiu aktach, przeł. $z$ oryginału indyjskiego, wstępem i objaśnieniami opatrzył S. Sch aye r, Warszawa 1923; wyd. 2 Siakuntala, przeł. S. Schayer, oprac. E. Słuszkiewicz, Wrocław 1957). Posiadamy też przekład autorstwa M. K. Byrskiego, (Wrocław 2017). W roku 2014 ukazała się książka, której autorem jest Elżbieta Kołdrzak, zatytułowana Śakuntala. Dramat indyjski Kalidasy. Zebrano w niej szczegółowe informacje m.in. na temat wystawień dramatu Kalidasy na polskich scenach teatralnych (E. Kołdrzak, Śakuntala. Dramat indyjski Kalidasy, Łódź 2014).

142 Najpierw Jones przetłumaczył Śakuntalę słowo po słowie na łacinę, dopiero potem przygotował tłumaczenie na język angielski.

${ }_{143}$ Georg Foster był niemieckim podróżnikiem i tłumaczem. Swoje wojaże rozpoczął bardzo wcześnie, bo już jako 18-letni młodzieniec. Tłumaczył $z$ wielu języków, m.in. z rosyjskiego, szwedzkiego, angielskiego i francuskiego. Sanskrytu jednak nie znał, był zatem skazany na tłumaczenie niebezpośrednie. Podczas wizyty w Londynie w roku 1790 natknął się na Śakuntalę w tłumaczeniu Jonesa i natychmiast zdecydował się na udostępnienie jej niemieckojęzycznemu odbiorcy. Przekład został opublikowany pt. Sakontala oder der entscheidende Ring. Ein indisches Schausspiel. Aus den Ursprachen Sanskrit und Prakrit ins Englische und aus diesem ins Deutsche übersetzt mit Erläuterungen von Georg Foster, Berlin 1791 (por. M. Ka ryekar, 
język niemiecki. Wzbudziło ogromne zainteresowanie w Europie, które obejmowało szczególnie kręgi poetów i intelektualistów niemieckich, takich jak np. Goethe, Herder, Heine, Jacobi, Schiller, bracia Schleglowie czy Wilhelm von Humboldt ${ }^{144}$. Pozostawili oni ślady swojego zainteresowania czy to $\mathrm{w}$ formie recenzji, czy listów ${ }^{145}$. Był także pierwszym Europejczykiem, który przetłumaczył na język angielski także fragmenty Gitagowindy (Gĩtagovinda) ${ }^{146}$, oraz pierwszym, który w roku 1792 opublikował w Kalkucie oryginalny tekst dzieła przypisywanego Kalidasie, zatytułowanego Ritusamhara (Ṛtusaṃhāra). Nadał mu tytuł The seasons: a descriptive poem by Calidas in the original Sanscrit ${ }^{147}$. Za największą zasługę Jonesa uważa się przetłumaczenie na język angielski i opublikowanie Manusmriti, słynnej indyjskiej księgi

Georg Foster's Śakuntalā, [w:] Transcultural Encounters between Germany and India: Kindred Spirits in the nineteenth and twentieth centuries, London-New York 2014, s. 13-24).

144 Wilhelm von Humboldt, najprawdopodobniej również dzięki lekturze tej właśnie wersji Śakuntali, zainteresował się sanskrytem na tyle poważnie, że kiedy będąc ambasadorem w Londynie w latach 1817-1818, spotkał Franza Boppa rozpoczął, w wieku 50 (sic!) lat naukę sanskrytu. Humboldt wyraził następującą opinię o swojej nauce sanskrytu nThe pleasure and satisfaction that I have experienced while learning Sanskrit... cannot be compared with any other possesion or any other joy, except, of course, learning Greek" ( ${ }_{n}$ Przyjemność i satysfakcja, jakiej doświadczam, ucząc się sanskrytu, jest nie do porównania z żadną inną, poza, oczywiście, nauką grekin). Cytat podaje za: Indology, Indomania and Orientalism: Ancient India's Rebirth in Modern Germany, Madison-New York 2009, s. 88.

145 Por. M. Ka ryek a r, Fostering aesthetic tolerance through literary translation Georg Foster's Śakuntalā, [w:] Transcultural Encounters between India and Germany. Kondred spirits in the nineteenth and twentieth centuries, New York 2014, s. 15.

146 As. Res. 3. 185-207; ponownie wydane w 1807 i 1849.

147 W publikacji użył czcionek alfabetu bengalskiego (por. F. Edgerton, op. cit., s. 8). 
praw ${ }^{148}$. Ukazało się ono pt. Institutes of Hindu Law: or, the ordinances of Manu, according to the gloss of Calluca... verbally translated from the original Sanscrit" w roku 1794 w Kalkucie ${ }^{149}$. Dzieło zostało niemal natychmiast przetłumaczone przez J. C. Hütnera na język niemiecki i ukazało się drukiem w roku 1797 w Weimarze. Nie sposób przecenić roli, jaką Bengalskie Towarzystwo Azjatyckie odegrało w historii poznawania indyjskiej tradycji, jak ważne były wydawane przez nie dzieła będące tłumaczeniami z języków oryginałów. Mimo że Jones nie starał się nawet pisać własnej gramatyki sanskrytu, jego działania niewątpliwie ułatwiały wielu $z$ innych badaczy zajmowanie się właśnie taką pracą. Dzięki temu, że stworzył platformę spotkań i wymiany myśli oraz informacji na temat dostępnych źródeł i sposobów ich wykorzystywania, zapisał się niewątpliwie w historii, także studiów nad sanskrytem, jako jedna z bardzo ważnych postaci, o której nie sposób nie wspomnieć przy okazji omawiania jakichkolwiek badań nad sanskrytem.

\section{Henry Thomas Colebrooke, A Grammar of the Sanscrit Language}

Kolejną postacią niezwykle ważną w dziele poznawania starożytnej kultury indyjskiej był Henry Thomas Colebrooke (1765-1837). Przez wielu jest on uważany za prawdziwego ojca sanskryckiej filologii i jednego z pierwszych indologów we współczesnym tego słowa znaczeniu. Colebrooke przyjechał do Indii w wieku 17 lat, w roku

148 Posiadamy w polszczyźnie doskonały przekład Manusmriti autorstwa indologa M. K. Byrskiego (Manu Swajambhuwa, Manusmryti, czyli Traktat o Zacności, tłum., wstęp, przedmowa, przypisy i słowniczek M. K. Byrski, Warszawa 1985; wyd. 2 Warszawa 1992).

149 Ponownie wydane m.in. w Londynie w roku 1796. Potem w 1807 i w 1863 w Madrasie w opracowaniu P. Percivala. 
1782, i przez pierwsze lata pobytu nie wykazywał zainteresowania sanskrytem, jego gramatyką ani literaturą. Po śmierci Williama Jonesa postanowił jednak kontynuować jego dzieło. Dopiero 11 lat po swoim przybyciu do Indii, czyli w roku 1793, zaczął poważnie interesować się staroindyjską kulturą. Wcześniej zdarzało mu się być bardzo krytycznym względem tak osób zajmujących się starożytnymi Indiami, jak ich prac. W listach do ojca określał np. Charlesa Wilkinsa jako osobę nanscrit mad" ("oszalałego na punkcie sanskrytun), a zawartość "Asiatick Miscellany" jako „a repository of nonsense" ( dowisko nonsensun) ${ }^{150}$. Być może było to dowodem na przenikliwość

\section{G R A M M R}

D: 2

SANSCRIT LANGUACE,

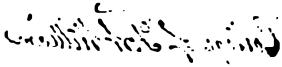

BY H. T. COLEAROORE, E.

Voluale I.

CALCUTTA:

TRINTED AT THE HONORABLE COMPINY, JKESS 1805 .

12. Henry Thomas Colebrooke, A Grammar of the Sanscrit Language, strona tytułowa jego umysłu. Mogły to być jednak także bardzo emocjonalne oceny egzaltowanego młodzieńca. Ponieważ od zawsze interesował się prawem, rozpoczął od ksiąg prawa. Interesował się też filozofią, religią, astronomią i arytmetyką. By móc czytać teksty poświęcone tym dziedzinom, za niezbędne uznał dobre poznanie gramatyki sanskrytu. Ale, jak pisze Higginbotham, ${ }_{n}[\ldots]$ trudności, jakie napotkał podczas swoich pierwszych prób poznania sanskrytu, były tak duże, że dwukrotnie, przed ostatecznym sukce- 
sem porzucał swoje starania"151. Był przekonany, że to gramatyka jest najważniejszym kluczem do możliwości dobrego i kompetentnego poznawania tekstów. Metoda, którą przyjął podczas jej poznawania, została nazwana metodą ninstruction by translations" ( ${ }_{n}$ formułowanie reguł gramatycznych na podstawie lektury tekstów oryginalnych") ${ }^{152}$. Wkrótce sama gramatyka stała się ważnym polem jego zainteresowań. Poza tekstami sanskryckimi dotyczącymi różnych dziedzin wiedzy czy też tekstami literackimi dodatkową lekturą były oryginalne dzieła indyjskich gramatyków. O źródłach, z których korzystał, pisał m.in. w artykule zatytułowanym On the Sanscrit and Pracrit languages, opublikowanym w roku 1803 w "Asiatick Researches" ${ }^{n}$. Napisał, podczas swojego pobytu w Indiach, jedną z pierwszych gramatyk sanskrytu zatytułowaną $A$ Grammar of the Sanscrit Language, która została wydana w Kalkucie w roku 1805 . We wstępie do tej gramatyki także wyliczał źródła, na których ją oparł. Wykazał tu ogromne oczytanie w literaturze gramatycznej. Były to bowiem nie tylko same gramatyki, ale także komentarze do nich ${ }^{154}$. Po pierwsze oparł ją na pracach autorstwa, jak sam pisał, "the three saints, who constitute the standard of Sanscrit grammar” ( trzech najważniejszych gramatyków, którzy ustanowili kanon reguł gramatyki sanskryckiej"), czyli na Paninim (Pāṇini), Katjajanie (Kātyāyana) i Patańdżalim (Patańjali) ${ }^{155}$. Dodał do nich komentarze do Mahabhaszji (Mahābhașya) autorstwa Kaiyaty

151 Ibidem, s. $77\left(_{n}[\ldots]\right.$ the difficulties he encountered in his first attempts to acquire the Sanscrit language were such, that he had twice abandoned the attempt before he finally succeeded").

152 Ibidem, s. 79.

153 H. T. Colebrooke, On the Sanscrit and Pracrit languages, [w:] Asiatic Researches, London 1803, s. 199-231.

154 Pełny ich spis jest zawarty w: $A$ Grammar of the Sanscrit language, vol. 1, Calcutta 1805, Preface, s. IX-XVI.

155 H. T. Colebrooke, op.cit., s. VI. 
(Kaiyata), dodał też komentarz do gramatyki Paniniego zatytułowany Kaśikawritti (Kaśikavṛtti), którego autorami byli Wamana (Vāmana) i Dżajaditja (Jayāditya), z uwagami Haradatty Miśry (Haradatta Miśra) z jego Padamańdżari (Padamańjari). To te właśnie prace stanowiły podstawę jego gramatyki. Konsultował jednak także Siddhantakaumudi (Siddhāntakaumudī), a także pracę, której autorem był Bhattodżi Dikszita (Bhatțoji Dỉkșita) o tytule Manorama (Manorama) wraz z komentarzami. Brał pod uwagę także gramatykę Prakrija Ćaumudi (Prākriya Ćaumudi) wraz z komentarzami Prasada (Prāsada) i Tattwa Ćandra (Tattvacandra). Odnosił się do Majtreji (Maitreya), Madhawy (Madhava) i do Wopadewy. We wstępie do gramatyki podawał także inne dzieła, które stanowiły dla niego źródła poboczne. Było to np. Writti Samgraha (Vṛtti-samgraha) ${ }^{150}$. Zadziwia ogrom jego wiedzy. Nikt przed nim nie opierał swojej znajomości gramatyki sanskrytu na tak ogromnym oczytaniu w indyjskiej literaturze gramatycznej. Colebrooke podkreślał niezwykłą, jego zdaniem, ważność literatury komentatorskiej, która pozwalała często na dogłębne zrozumienie tekstów samych gramatyk. Czyż Panini jest zrozumiały bez komentarzy? To pytanie jest aktualne do dzisiejszego dnia. Colebrooke przebrnął przez teksty, które William Jones swego czasu nazwał ndark as the darkest oracle” ("niejasnymi jak najbardziej niejasna z przepowiedni") ${ }^{157}$. Pierwotnym zamiarem Colebrooke’a było napisanie krótkiej i podstawowej gramatyki ("brief and elementary"), jego celem były "conciseness and perspicuity" ("zwięzłość i klarownośćn) ${ }^{158}$. Czas pokazał jednak, że nie było to tak łatwe. W trakcie pracy okazało się

\section{Ibidem.}

157 Colebrooke we wspominanym już artykule On the Sanscrit and Pracrit Languages odwołuje się do takiego właśnie określenia, którego Jones użył kiedyś odnośnie do oryginalnych gramatyk napisanych przez miejscowych znawców (ibidem, s. 209).

158 Ibidem, s. III, s. VII. 
bowiem, że taka skrótowość jest po prostu dla Colebrooke’a niemożliwa. Skończyło się zatem na wydaniu tylko pierwszego tomu, który z natury rzeczy nie obejmował całości zagadnień. Gramatyka ta składa się z 23 rozdziałów, podzielonych na części, a w ich ramach na paragrafy. Rozdziały 1 i 3 poświęcone są głównie fonetyce. Zawierają informacje ogólne na temat dźwięków (czy „letters”, jak Colebrooke je nazywa), ich połączeń, ułożenia, natury i długości np. samogłosek i dwugłosek. Są wiadomości na temat stopniowania samogłosek i ich rozmaitych kombinacji. Rozdział 2 jest zatytułowany On the Parts of Speech and on the Key to the Rules of Grammar. Ma zatem naturę bardzo ogólną. W rozdziałach 4-12 Colebrooke pisze o deklinacji. Po uwagach ogólnych dzieli poszczególne rzeczowniki ze względu na ich zakończenia i podaje ich odmianę. Rozdział 13 dotyczy rodzajów rzeczowników, 14 - derywacji rzeczowników rodzaju żeńskiego. Od rozdziału 16 rozpoczyna się prezentacja koniugacji. Na początku Colebrooke podaje reguły ogólne dotyczące rdzeni czasownikowych, możliwych afiksów ich kombinacji. W rozdziale 17 omawia augmenty, w 18 i 19 pisze o możliwych zmianach w obrębie samych rdzeni czasownikowych, które zachodzą w określonych warunkach. Rozdział kolejny zawiera prezentację odmiany rdzenia bhū. W rozdziałach 20-23 skupia się na rdzeniach klasy pierwszej. Książka kończy się przedstawieniem planów dotyczących dalszej części gramatyki. Colebrooke planował, by zawierała ona informacje dotyczące pozostałych dziewięciu klas czasowników, czasowników dery wowanych, etymologii rzeczowników i participiów (ich pochodzenia od rdzeni czasownikowych). Miała dotyczyć też tematu złożeń, derywacji rzeczowników tworzonych od rzeczowników, przymiotników, stopniowania i innych jeszcze ważnych, jego zdaniem, zagadnień. Niestety ta dalsza część nie została już napisana, a w każdym razie nie została opublikowana.

W tym samym 1805 roku Colebrooke został mianowany przez lorda Wellesleya honorowym profesorem prawa indyjskiego i sanskrytu 
w Fort William College. Jego obowiązki nie obejmowały nauczania, raczej była to funkcja nadzorcza. Uczestniczył w egzaminach językowych, w tym w egzaminach z sanskrytu. Niedługo potem został wybrany przewodniczącym Asiatic Society of Calcutta ${ }^{159}$. W roku 1807 opublikował swoją wersję słownika Amarakośa (Amarakośa) zatytułowaną Koscha, or Dictionary of the Sanscrit language by Umura Singha with an English Interpretation and Annotations by H. T. Colebrooke. W roku 1810 wydał też, jako pierwszy Europejczyk, gramatykę Paniniego ${ }^{160}$ Asztadhjaji (Așțādhyāyi) ${ }^{161}$. Colebrooke odebrał w młodości wykształcenie klasyczne. Był posiadaczem ogromnej kolekcji książek

159 W zasobach Towarzystwa znajduje się m.in. książka zawierająca informacje biograficzne dotyczące Colebrooke'a.

160 Pełne imię Paniniego podaje się jako Daksziputra Panini (Dākṣīputra Pāṇini).

161 Panini to gramatyk żyjący najprawdopodobniej w VI, V bądź IV wieku p.n.e. na północnym Zachodzie Indii, w Gandharze, w miejscowości Śalatura (Śālatura). W związku z tak przypisywanym mu miejscem zamieszkania był także nazywany czasem Śalaturija (Śālāturīya), tym, który pochodzi z Śalatury (por. H. Sch a rfe, op. cit., s. 88). Jest on powszechnie uważany za największego indyjskiego gramatyka. Jego gramatyka składa się z ośmiu ksiąg. Księga pierwsza zawiera terminy gramatyczne i zasady analizy. W drugiej omówiono wyrazy złożone i system przypadków, w trzeciej derywację (przyrostki podstawowe), w czwartej i piątej derywację (przyrostki wtórne), w szóstej i siódmej akcent i alternację wokaliczną, a w ostatniej, ósmej, składnię. Całość uzupełniona jest o listę rdzeni. Panini zawarł treść swojej gramatyki w około 4000 (3967) reguł zapisanych w ogromnie skrótowy sposób, w regułach typu sutra. Niewątpliwie gramatyka ta była przeznaczona do studiowania dopiero po wcześniejszym nauczeniu się jej na pamięć, jako że bardzo często zdarza się, iż tylko biegłe poruszanie się $\mathbf{w}$ całej jej treści pozwalało na poznawanie samej gramatyki. Tak właśnie działo się w Indiach, zresztą zwyczaj ten jest w Indiach wielokrotnie kontynuowany. Nauczyciel wyjaśnia uczniom zastosowanie reguł gramatyki, dopiero gdy opanują ją na pamięć. Asztadhjaji Paniniego została później wydana w Europie w opracowaniu O. Boehtlingka. 
i manuskryptów ${ }^{162}$, które po powrocie do Wielkiej Brytanii, w roku 1818, przekazał Kompanii Wschodnioindyjskiej. Obecnie kolekcja ta jest jednym ze skarbów India Office Library w Londynie. W roku 1823 został założycielem Royal Asiatic Society, bardzo prestiżowego, działającego do tej pory towarzystwa skupiającego orientalistów ${ }^{163}$.

5. Horace Hayman Wilson, An Introduction to the Grammar of Sanskrit Language for the use of early students

Horace Hayman Wilson (17861860) był brytyjskim orientalistą, który wyjechał do Indii, do Bengalu w roku 1808. Ponieważ szybko zainteresował się językami i literaturą staroindyjską z polecenia Henry Thomasa Colebrooke'a został, w roku 1811, sekretarzem The Asiatic Society of Bengal. Przez wiele lat był związany

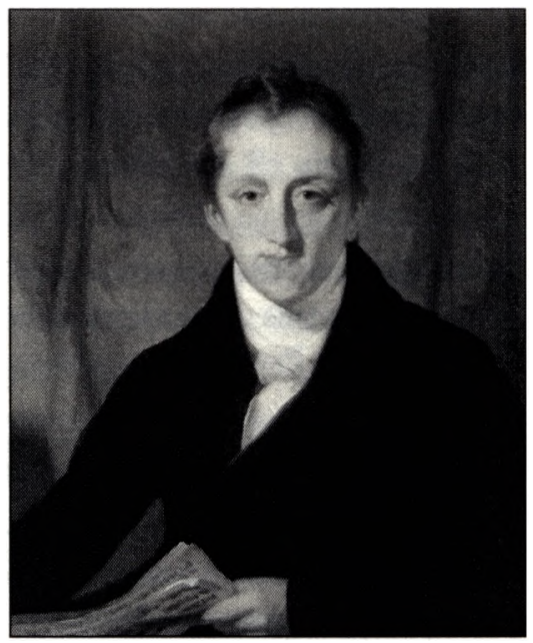

13. Horace Hayman Wilson z działalnością Sanskrit College w Kalkucie. W 1832 roku został wybrany pierwszym profesorem powstałej wtedy w Oksfordzie katedry Boden Chair of Sanskrit. W roku 1836 został bibliotekarzem w The East India Company. Uczył także

\footnotetext{
162 Ich liczba określana jest bardzo precyzyjnie na 2749.

103 Również tu okazał się bardzo hojnym darczyńcą. Podarował bowiem Towarzystwu w roku 1824 swoją kolekcję rysunków, na których znajdowały się przede wszystkim najrozmaitsze indyjskie przedmioty, poczynając od narzędzi rolniczych, a na instrumentach muzycznych kończąc.
} 
w East India Company College. Był członkiem założycielem Royal Asiatic Society i od roku 1837 aż do swojej śmierci, jego dyrektorem. W roku 1841 wydał w Londynie własną gramatykę sanskrytu zatytułowaną An Introduction to the Grammar of the Sanskrit Language for the use of early Students ${ }^{164}$. Nie była ona jednak, także ze względu na swoją cenę, pracą popularną. Jak się wydaje, mimo że była wspominana przez innych autorów gramatyk sanskrytu, nie wpłynęła w sposób znaczący na europejską tradycję gramatyk sanskrytu.

Jeszcze jedną ciekawą osobą, może nie tak istotną dla europejskiej tradycji opisów gramatyki sanskrytu, ale niewątpliwie istotną $\mathrm{w}$ dziele przekazywania informacji na jego temat, był Alexander Hamilton (1762-1824). Był to Szkot, syn Williama Hamiltona, kupca, profesor sanskrytu w Hertford College. $Z$ czasem został także profesorem w Haileybury College. Był tam odpowiedzialny za katedrę Sanscrit and Hindoo literature. Hamilton dotarł drogą morską do Indii, do Bombaju, w roku 1783. Wkrótce został członkiem Asiatic Society of Bengal. Rosane Rocher pisze w artykule dotyczącym biografii Aleksandra Hamiltona, że był częstym krytykiem prac innych autorów w "Monthly Review”. Pisał też teksty do „Asiatic Annual Register" oraz do Edinburgh Reviewn". Hamilton wrócił do Europy wraz z Charlesem Wilkinsem ${ }^{165}$ pomiędzy rokiem 1797 a 1800 . Udali się najpierw do Londynu. Następnie Hamilton, już sam, w roku 1802 pojechał do $\mathrm{Pa}-$ ryża, by tam opracowywać manuskrypty znajdujące się $w$ Biliothèque Nationale ${ }^{160}$. Zajmował się tą pracą dłużej niż 10 lat, a jej owocem było stworzenie katalogu tychże manuskryptów. W roku 1815 wydał

104 Jej drugie wydanie ukazało się także w Londynie w roku 1847.

165 Hamilton pomagał Wilkinsowi w wydaniu w roku 1811 poprawionej wersji jego książki The Gidopadesha in Sanskrit Language.

106 Znajdujący się w bibliotece zbiór manuskryptów składał się w największej części z tych przywiezionych do Paryża na początku XVIII wieku przez Jeana François Ponsa. 
pracę zatytułowaną Terms of Sanskrit Grammar, a w $1820 \mathrm{~A} \mathrm{Key} \mathrm{to}$ Chronology of the Hindus. W Paryżu uczył sanskrytu, a jego uczniami byli m.in. Jean-Louis Burnouf, Franz Bopp, Othmar Frank i August von Schlegel. Był nim także Friedrich Schlegel (1772-1829), niemiecki językoznawca i literaturoznawca. Nauczycielem tego ostatniego był także Antoine-Léonard de Chézy. Schlegel w pracy Über die Sprache und Weisheit der Indier, co można przetłumaczyć jako O jezzku i mądrości Indii, wydanej w 1808 roku w Heidelbergu stwierdził, że pomiędzy greką, łaciną, językiem perskim, językami germańskimi a sanskrytem są niewątpliwie liczne podobieństwa. Można je znaleźć zarówno w obrębie słownictwa, jak i gramatyki. Hamilton pozostawił kilka prac dotyczących sanskrytu i sanskryckiej literatury. Wraz z Charlesem Wilkinsem pracował też nad tekstem Hitopadeśi. Owocem ich wspólnego działania jest książka The Hitopadesa in the Sanscrit Language, wydana w Londynie w roku 1811. Widać jasno, iż Hamilton odegrał istotną rolę $\mathrm{w}$ przekazywaniu wiedzy dotyczącej sanskrytu przede wszystkim przybyłym do Paryża przyszłym niemieckim znawcom kultury indyjskiej i gramatyki sanskrytu.

\section{Monier Monier-Williams, A Practical Grammar of the Sanskrit language}

Kolejny badacz sanskrytu i twórca jego gramatyki to Monier Monier-Williams (1819-1899), który już jako młody człowiek rozpoczął, w latach 1838-1840, studia w Oksfordzie, najpierw w King's College, a później w Balliol College. Później pobierał nauki w ramach East India Company College (1840-1841) i wreszcie w University College, w Oksfordzie (1841-1844). Od 1844 roku nauczał języków orientalnych w East India Company College (1844-1858). Monier-Williams był drugim Boden Professor of Sanskrit w Oksfordzie. W roku 1853 założył Indian Institute. 
Monier-Williams napisał, jako kolejna osoba, własną gramatykę sanskrytu. Została ona po raz pierwszy wydana w roku 1846. W 1878 opublikował jej czwarte, poprawione i rozszerzone wydanie zatytułowane $A$ Practical Grammar of the Sanskrit Language ${ }^{167} . Z$ treści gramatyki wynika, że Williams znał klasyczną indyjską gramatykę Paniniego ${ }^{168}$. Przywołuje ją bowiem, szczególnie w części dotyczącej fonetyki. Znał także prace innych gramatyków indyjskich, jakkolwiek nie wymienia ich z imienia, odwołując się jedynie

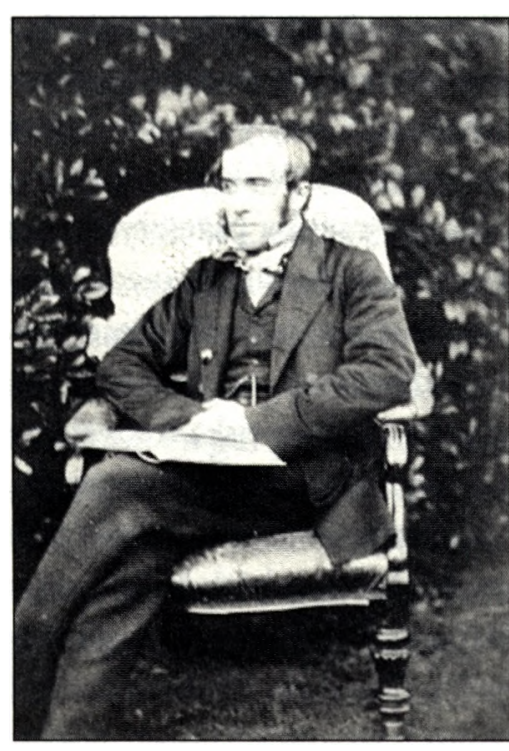

14. Monier Monier-Williams ogólnie do swej znajomości „native grammars”. W opisie tak poszczególnych form, jak i zagadnień gramatycznych używa gramatycznej terminologii sanskryckiej. Od czasu do czasu porównuje poszczególne formy sanskryckie do form wedyjskich. Można także znaleźć w jego gramatyce informacje, które wskazują na orientację w językach drawidyjskich ${ }^{169}$ czy we współcześnie mu

167 Jej pełny tytuł brzmi: A Practical Grammar of Sanskṛit: arranged with reference to the Classical Languages of Europe, for the use of English students by Monier Williams. To właśnie ta wersja była wydana ponownie w Indiach w roku 1978, czyli dokładnie 100 lat po jej pierwotnym wydaniu. Jest to fakt wart podkreślenia, jako że wskazuje na aktualność takiego właśnie sposobu przedstawiania gramatyki sanskrytu.

${ }_{108}$ O Śiwasutrach (Śivasūtra) Paniniego wzmiankuje np. na stronie 14 (por. M. Monier-Williams, op. cit., s. 14).

169 Np. ibidem, s. 17. 
używanych językach indyjskich, takich jak bengali, hindi, marathi czy gudżarati. Oczywiście, zgodnie z tytułem, relatywnie często podaje i dyskutuje formy greckie i łacińskie, jego zdaniem, analogiczne do sanskryckich. Wskazuje także na różnice np. w funkcjach przypadków czy czasów przeszłych i przyszłych ${ }^{170}$. Nie można jednak jego gramatyki określić mianem gramatyki porównawczej. W największej mierze jest to jednak gramatyka opisowa. W całej gramatyce używa w podawanych przykładach alfabetu dewanagari, wpisując się tym samym w europejską tradycję używania form nietranskrybowanych lub nie tylko transkrybowanych.

Monier-Williams opisuje poszczególne zagadnienia w dziewięciu rozdziałach, podzielonych następnie na podrozdziały. Kolejność, w jakiej przedstawia materiał gramatyczny, jest w dużej mierze ${ }_{n}$ tradycyjna $^{n 171}$. Opisuje bowiem na początku fonetykę, następnie rdzenie i tworzenie form nominalnych, deklinację rzeczowników, przymiotników, liczebników i zaimków. Potem przechodzi do kategorii verbum, aby podobnie jak poprzednio podać najpierw wiadomości ogólne, a następnie opisać podział rdzeni na klasy i formy właściwe poszczególnym czasom i trybom. Omawia też szczegółowo conditionalis, infinitivus, passivum, causativum, desiderativum, frequentativum i intensivum. Pisze o czasownikach odrzeczownikowych. Szczegółowo omawia imiesłowy, podając bardzo dużo przykładów. W rozdziale 7 skupia się na formach nieodmiennych, by $w$ rozdziale 8 przedstawić informacje dotyczące złożeń. Wreszcie w ostatnim rozdziale (9) omawia zagadnienia związane ze składnią. Gramatyka zaopatrzona jest krótkim dodatkiem zawierającym ćwiczenia. Ćwiczenia te polegają głównie na lekturze materiału podanego i opisanego szczegółowo przez autora gramatyki, a nie na pracy samodzielnej. Williams podaje bowiem

170 Np. ibidem, s. 18-29.

171 W znaczeniu tradycji europejskich opisów gramatyki sanskrytu. 
jeden krótki fragment tekstu sanskryckiego w alfabecie dewanagari wraz z jego tłumaczeniem na język angielski (bajka o mędrcu i myszy z Hitopadeśi). Następnie dołącza komentarz, w którym poddaje analizie poszczególne, użyte w tekstach, formy gramatyczne. Dodatkowo ta część gramatyki zawiera jednostronicowy tekst, w którym ćwiczone są zaimki i wybrane formy rzeczowników oraz czasowników ${ }^{172}$. Być może Williams planował wydanie większej liczby ćwiczeń w osobnym zbiorze bądź starał się jedynie wskazać możliwą, jego zdaniem, drogę sposobów praktycznego ćwiczenia form i reguł gramatycznych. Williams dodaje do swojej gramatyki krótki przegląd podstawowych metrów sanskryckich. Jego przegląd jest jednak o wiele mniej szczegółowy niż ten dokonany przez Theodora Benfeya. Dzieli je na dwie duże grupy: warnawritta (varṇavṛtta) i matrawritta (mātrvṛtta) ${ }^{173}$. Dołącza też bardzo przydatne w lekturze cztery alfabetyczne indeksy (indeks słów angielskich na oznaczenie poszczególnych, używanych w gramatyce form i zagadnień gramatycznych, indeks wybranych wyrazów sanskryckich, indeks terminów gramatycznych i nazw metrów oraz indeks sufiksów) ${ }^{174}$. Monier-Williams wydał także w roku 1855 własne tłumaczenie Śakuntali zatytułowane Sakoontala or the Lost Ring. An Indian Drama ${ }^{175}$. W tym czasie nauczał języków orientalnych

172 M. Monier-Williams, op. cit., s. 387-392.

173 Dokładne omówienie znajduje się w: ibidem, s. 392-397.

174 Ibidem, s. 403-414.

175 Wyd. 1 Hertford: Stephen Austin 1855; wyd. 5 London: John Murray 1887; wyd. 7 poprawione pochodzi z roku 1894, London-New York: George Routledge and Sons Limited (New York: The Colonial Press 1900) w ramach The World's Great Classics: Hindu Literature-Comprising The Book of Good Counsels, Nala and Damayanti, Sakoontala, The Ramayana and Poems of Toru Dutt. O popularności tej wersji tłumaczenia świadczy fakt, iż także współcześnie pojawiają się jej reprinty: Adamant Media Corporation 2005; Cosmo Publications, New Delhi 2005; Hesperides Press 2006; Dodo Press 2007, Echo Library 2007; Wentworth Press 2016. W roku 1885 tłumacze- 
w East India Company College. Wydał też poprawione przez siebie tłumaczenie opowieści o Nalu i Damajanti autorstwa Henry'ego Harta Milmana. Jego tytuł brzmiał Nalopakhyanam. Story of Nala. An episode of the Mahabharata: the Sanskrit text with a copious vocabulary and an improved version of Dean Milman's translation by Monier Williams ${ }^{176}$. Monier-Williams był także autorem dwóch słowników, które do tej pory są używane przez bardzo szerokie grono osób zajmujących się w ten czy inny sposób sanskrytem. Były to: A Dictionary English and Sanskrit, wydany po raz pierwszy w roku 1851, potem wielokrotnie wznawiany ${ }^{177}$, oraz $A$ Sanskrit-English Dictionary, który po raz pierwszy ukazał się w roku $1872^{178}$.

nie to zostało także opublikowane w Nowym Jorku przez Dodd, Mead and Company (110 kopii na specjalnym papierze).

176 Wyd. 2 poprawione, Oksford: Clarendon Press 1879.

177 Autor we wstępie do niego pisze, iż zachęcił go do jego stworzenia H. H. Wilson i że praca nad nim zajęła mu około siedmiu lat (por. M. Monier-Williams, op. cit., s. IX).

${ }_{178}$ O słownikach autorstwa M. Moniera-Williamsa obszerniej w jednym $z$ dalszych rozdziałów. 


\section{Część IV}

Gramatyki sanskrytu w języku niemieckim - XIX wiek 



\section{W}

łaśnie na początku XIX wieku rozpoczęła się epoka, w której sanskrytem i jego gramatyką zaczęli zajmować się badacze, którzy nie byli osobiście w Indiach. Posiadali zatem wiedzę niebezpośrednią, pochodzącą w największej mierze od tych, którzy często spędzili lata w Indiach i pracowali z pomocą indyjskich panditów.

\section{Franz Bopp, Kritische Grammatik der Sanskrita-Sprache}

W'́ród badaczy niemieckich jednym z najwybitniejszych, o ile nie najwybitniejszym, był niewątpliwie urodzony w Moguncji uczeń orientalisty K. J. Windischmanna Franz Bopp (1791-1867) ${ }^{179}$. Bopp sanskrytu nauczył się przede wszystkim sam. Podczas tych samodziel-

179 Uczniem Boppa był m.in. Max Müller (1823-1900), wybitny niemiecki orientalista, w którego dorobku znajdują się liczne prace z zakresu szeroko pojętej indologii. Pod jego kierunkiem powstał m.in. zbiór ogromnej liczby przekładów dzieł sanskryckich na język angielski używany przez badaczy również współcześnie. Była to seria zatytułowana Sacred Books of the East. Müller był także autorem jednej z wielu powstałych w XIX wieku gramatyk sanskrytu. Kierował ja przede wszystkim do osób rozpoczynających swoją przygodę z sanskrytem. Jej tytuł brzmiał $A$ Sanskrit Grammar for Beginners. Została ona wydana w roku 1866. Uczniem Boppa był także August Wilhelm von Schlegel, który został potem profesorem sanskrytu. W roku 1818 ustanowiono dla niego katedrę na uniwersytecie w Bonn. Był nim także Adolf Friedrich Stenzler. Ciekawostką jest to, iż Bopp był opiekunem dysertacji De negatione, napisanej przez Hipolita Cegielskiego (1813-1868), filologa polskiego, wykładowcy języków greckiego i łacińskiego, znanego przemysłowca. Cegielski pobierał nauki na Uniwersytecie Berlińskim i wtedy właśnie miał okazję zetknąć się z F. Boppem. 


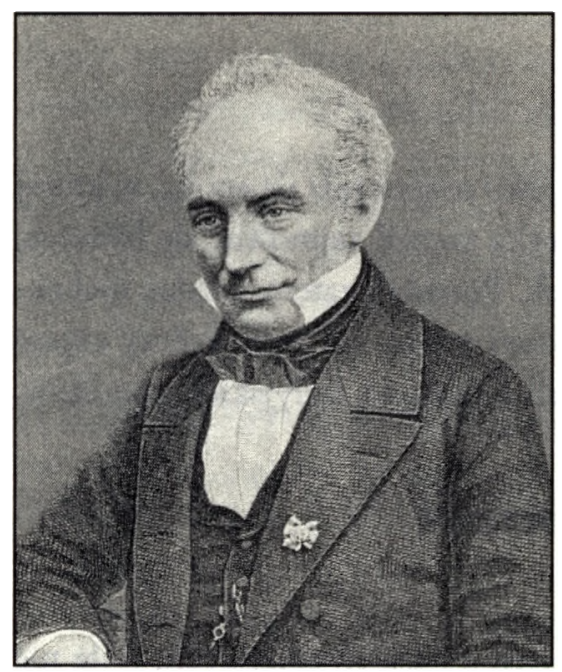

15. Franz Bopp

nych studiów zetknął się jednak w Paryżu, do którego udał się w roku 1812 celem poznania języków orientalnych, w tym sanskrytu, z Aleksandrem $\mathrm{Ha}$ miltonem, Antoine'em-Léonardem de Chézym, z Antoine'em Isaakiem Silvestre'em de Sacym $^{180}$ oraz z Louisem-Mathieu Langlèsem ${ }^{181}$. Poza sanskrytem w Paryżu studiował także język perski i hebrajski. Bopp był znany $z$ tego, że ogromną ilość czasu spędzał w bibliotekach, w tym $w$ Biliothèque Nationale, $z$ jej obszerną kolekcją manuskryptów. Studiował też dostępne wtedy w stolicy Francji prace wydawane w Kalkucie oraz w Serampore. Bopp już w roku 1816 wydał pracę zatytułowaną Über das Konjugationssystem der Sanskritsprache in Vergleichung mit jenem der griechischen, lateinischen, persischen und germanischen Sprache, która stała się pierwszym z jego dzieł z zakresu językoznawstwa porównawczego. Był prekursorem takiego właśnie spojrzenia na język. Istotne było, iż porównywał ze sobą całe systemy form językowych np. wszystkie odmiany czasowników, a nie pojedyncze wyrazy wyjęte z całości języka. Tak właśnie w Europie robiono do tej pory. Praca

180 Antoine Isaac Silvestre de Sacy (1758-1838) był znanym francuskim językoznawcą i orientalistą. Jego szczególnym zainteresowaniem cieszył się język arabski. Był współzałożycielem Société Asiatique. Pośród jego studentów był także znany z zainteresowań i prac sanskrytologicznych Johann Gottfried Ludwig Kosegarten.

181 Louis-Mathieu Langlès był uczniem Silvestre’a Sacy'ego. 
Boppa stała się zatem przełomem w sposobie postrzegania języka. Badał języki, przede wszystkim odnajdując w nich wspólnotę pochodzenia za pomocą porównywania określonych form gramatycznych $w$ ich rozwoju historycznym. Już w tej pierwszej pracy wykazał się niewątpliwie bardzo dobrą znajomością sanskrytu. Podczas swego pobytu w Londynie, gdzie udał się w roku $1817^{182}$ celem studiowania indyjskich manuskryptów $\mathbf{z}$ Wilhelmem von Humboldtem (1767-1835) ${ }^{183}$, poznał Charlesa Wilkinsa i Henry'ego Thomasa Colebrooke'a ${ }^{184}$. To właśnie tam, w roku 1820, ukazało się angielskie tłumaczenie jego dzieła, uzupełnione i rozszerzone o system deklinacyjny. Jego tytuł brzmiał Analytical Comparison of the Sanskrit, Greek, Latin and Teutonic Languages, Showing the Original Identity of their Grammatical Structure. Od roku 1821 był związany z uniwersytetem w Berlinie, gdzie specjalnie dla niego, za wstawiennictwem Wilhelma von Humboldta ${ }^{185}$, utworzono katedrę sanskrytu i gramatyki porównawczej.

182 Bopp przebywał w Londynie do roku 1820.

183 Bopp w dziedzinie sanskrytu był nauczycielem Humboldta.

184 Efektem pobytu Boppa w Londynie było m.in. wydanie w roku 1819 łacińskiego tłumaczenia, pochodzącego z Mahabharaty poematu o Nalu i Damajanti (Nalus, carmen sanscritum e mahabharato: edidit, latine vertit, et adnotationibus illustravit Franciscus Bopp). Było to opracowanie krytyczne (dokładniejsze informacje na temat tego opracowania por. l. Milewska, Lacina jako łączilk międzykulturowy, czyli Franz Bopp i jego tłumaczenie sankryckiej opowieści o Nalu i Damajanti, „Nowy Filomata” 2016, vol. 20, nr 1, s. 163-175). Wraz z Augustem Schleglem wydał także w roku 1823 tekst Bhagawadgit $\gamma$, a samodzielnie, w roku 1824, w Berlinie tłumaczenie innego fragmentu z Mahabharaty zatytułowanego Indralokagama (Ardschuna Reise $z u$ Indra's Himmel) oraz kilku jeszcze innych fragmentów tego indyjskiego eposu. Świadczy to niewątpliwie o jego oczytaniu w sanskrycie epickim. ${ }_{185}$ Wilhelm von Humboldt znany jest m.in. z tego, ze zastosował wypracowane przez F. Boppa pojęcie systemu do badań nad typami struktur językowych. Opracował też, stosowaną w ciągu całego praktycznie XIX wieku, typologię języków. 
W roku 1827 wydał kolejną książkę poświęconą sanskrytowi. Jej tytuł brzmiał Ausführliches Lehrgebäude der Sanskrita-Sprache. W roku 1832 wydał jej łacińską wersję o tytule Grammatica critica, a w roku 1834 wersję skróconą zatytułowaną Kritische Grammatik der Sanskrita-Sprache in kürzerer Fassung ${ }^{186}$. To ta właśnie wersja stała się podstawą wiedzy o sanskrycie dla wielu innych europejskich badaczy zainteresowanych gramatyką tego języka ${ }^{187}$. Gramatyka ta ma w głównej mierze charakter opisowy. Została podzielona na kilka części: część teoretyczną, część, w której autor podaje sanskrycki tekst (w alfabecie dewanagari oraz w transkrypcji) fragmentu opowieści o Nalu i Damajanti, tytułując go Sprachprobe, oraz indeks poruszanych w książce zagadnień gramatycznych. W swoim wykładzie przykłady poszczególnych form gramatycznych podaje Bopp w alfabecie dewanagari, zakładając, że czytelnik, po zapoznaniu się z rozdziałem 1 (Schrift und Aussprache), poświęconym fonetyce i pisowni, jest w stanie tym właśnie alfabetem się posługiwać. Rozdział 2 poświęca Bopp regułom sandhi (Wohllautsregeln). Książka zawiera liczne zestawienia form gramatycznych przedstawione $w$ formie czytelnych tabel. Cały rozdział Bopp poświęca pierwiastkom czasownikowym i prefiksom (Von den Wurzeln und Praafixen). W rozdziale tym odwołuje się do pracy Wilkinsa zatytułowanej The radicals of the Sanscrita language oraz F. Rosena Radices Sanscritae i, wydanej w roku 1841, Westergaarda Radices linguae Sanscritae. Porównuje formy sanskryckie z formami wedyjskimi, w szczególności z tymi pochodzącymi z Rigwed $\gamma$. Kolejny rozdział (Nomen) poświęca właśnie kategorii nomen, omawiając wszystkie najważniejsze, a wiążące się z nią tematy. Szczegółowo omawia odmianę

186 Jej drugie wydanie ukazało się w roku 1854.

187 Między innymi z gramatyk Boppa, jako źródeł podstawowych, czerpali wiedzę polscy badacze: Walenty Skrochód-Majewski i Franciszek Xawery Malinowski. 
rzeczowników, podając schematy wybranych odmian w układzie poziomym, co nie jest obecnie, ani nigdy wcześniej nie było, typowe. W kolejnym paragrafie tego rozdziału skupia się na przymiotnikach, a następnie na liczebnikach: głównych i porządkowych. Następnie omawia zaimki. Rozdział 5 (Verbum) Bopp poświęca kategorii verbum, pisząc szczegółowo o czasach i trybach. Wspomina tutaj o indyjskiej gramatyce Mugdhabodha autorstwa Wopadewy, pisząc jednocześnie, iż nie przestudiował jej osobiście, ale zna jej treść tylko za pośrednictwem gramatyk napisanych przez Brytyjczyków. Dalej pisze o podziale czasowników na 10 klas, w pierwszej części podając zestaw końcówek właściwych poszczególnym trybom. Krótko omawia czasy, zaopatrując tę część w tabele przedstawiające odmianę czasowników. Kolejna część zawiera rozbudowane informacje dotyczące form właściwych poszczególnym klasom oraz form obocznych. Dalej przedstawione są reguły tworzenia poszczególnych czasów. I ta część kończy się zestawieniami podanymi $w$ formie przejrzystych tabel. W rozdziale kolejnym (Verba derivativa) omówione są koniugacje pochodne ${ }^{188}$. W kolejnym (Wort-Buildung) Bopp skupia się przede wszystkim na participiach, formach infinitivum i gerundium. Złożeniom poświęca Bopp uwagę w rozdziale następnym (Composita), omawiając je w kolejności, jak następuje: złożenia kopulatywne, dwandwa, posesywne, bahuwrihi, determinatywne, karmadharaja, złożenia typu tatpurusza, kolektywne, dwigu i adwerbialne awjajibhawa ${ }^{189}$. Rozdział ostatni

188 Ciekawostką jest fakt powoły wania się Boppa na podobieństwa występujące pomiędzy gramatyką sanskrytu i języka bengalskiego. Wynika $z$ tego bowiem, iż także język bengalski był w kręgu jego zainteresowań i kompetencji.

189 W kontekście złożeń Bopp powołuje się m.in. na znane mu gramatyki $w$ języku angielskim i na prace $\mathrm{K}$. Windischmanna. Wspomina także antologię tekstów Lassena. Niektóre z przykładów podaje, wskazując na konkretną lokalizację w opowieści o Nalu i Damajanti. 
(Indeclinabilia) poświęcony jest formom nieodmiennym. Lektura gramatyki Boppa jasno wskazuje na jego ogromne oczytanie w literaturze przedmiotu. Widać, iż jej autor nie tylko przestudiował dogłębnie dostępne mu prace, ale i stworzył dzieło nowe. Jego niezwykle precyzyjna, tak w zakresie teoretycznym, jak i w zakresie podawanych przykładów, gramatyka stała się na lata źródłem wiedzy o sanskrycie i wzorem dla gramatyk tworzonych później przez wielu autorów europejskich. W następnych latach Bopp skupił się na dalszej pracy nad gramatyką porównawczą, wydając kolejne jej tomy, zatytułowane Vergleichende Grammatik des Sanskrit, Zend, Griechischen, Lateinischen, Lithuanischen, Altslavischen, Gotischen und Deutschen. Ukazywały się one w Berlinie ${ }^{190}$. Tomy te potwierdzały niezwykłą wiedzę Boppa i jego biegłość w znajomości innych języków. Jak pisze Adam Heinz, Bopp pragnął trzech rzeczy: „1. przedstawić w sposób systematyczny stosunki pokrewieństwa języków indoeuropejskich; 2. zbadać rządzące ewolucją języka "fizyczne i mechaniczne" prawa; 3. ustalić początki głównych kategorii morfologicznych". Heinz pisze także, iż co do metody W intencji autora miała to być więc lingwistyka stawiająca sobie cele filozoficzne i posługująca się metodami biologicznymi" ${ }^{n 191}$.

Bopp był niewątpliwie jednym z najwybitniejszych europejskich językoznawców i mimo że swoją wiedzę dotyczącą sanskrytu opierał głównie na źródłach pośrednich ${ }^{192}$, nie studiując samodzielnie oryginalnych, indyjskich gramatyk, wskazał wielu następcom drogę do bardzo rzetelnych studiów językoznawczych. Stworzył podwaliny gramatyki historyczno-porównawczej, mimo że, jak się wydaje, przede wszystkim pragnął zrekonstruować początki mowy ludzkiej.

190 Były to lata $1833,1835,1842,1847,1849,1852$.

191 A. Heinz, Dzieje jezzkoznawstwa w zarysie, Warszawa 1978, s. 135.

192 Przede wszystkim były to gramatyki Wilkinsa i Colebrooke’a, ale także Yatesa, Careya i Forstera. 
Był świetnym analitykiem, który pokazał, jak powinna wyglądać gramatyka historyczno-porównawcza i jakiej użyć do jej stworzenia metody. Przebadał oprócz sanskrytu ogromny materiał wykraczający poza rodzinę języków indoeuropejskich. Idee Boppa w Niemczech rozwijał m.in. jeden z jego uczniów Franz Wüllner. Warto dodać, że Bopp był także autorem wydanego w roku 1830 słownika porównawczego zatytułowanego Glossarium comparativum linguae sanscritae in quo omnes sanscritae radices et vocabula usitatissima explicantur et cum vocalibus graecis, latinis, germanicis, lithuanicis, slavicis, celticis comparantur ${ }^{193}$, później Sanskrit and Latin Dictionary ${ }^{194}$.

To właśnie o Boppie współczesny znawca sanskrytu Johan Frederik Staal pisał: „Jakikolwiek byłby zakres jego wiedzy, nie było w Niemczech w tym czasie nikogo innego, kto lepiej od niego znałby sanskryt"195.

Sanskryt na przełomie XVIII i XIX wieku stał się językiem, z którym Europejczycy mieli możliwość zapoznania się na tyle dokładnie, że sposób jego opisywania zaczął wpływać na europejskie badania językoznawcze. Jak pisze Adam Heinz, dla Europejczyków sposób opisu gramatyki sanskrytu stał się bodźcem rozwoju analizy fonetycznej i morfologicznej, alternacji wokalicznej, koncepcji rodziny indoeuropejskiej, naukowej etymologii i ogólnometodologicznym w sensie naukowej ścisłości opisu ${ }^{196}$. Podobnie Tadeusz Milewski w wydanej już wcześniej, bo w roku 1965, książce zatytułowanej Jezykoznawstwo stwierdza, iż właśnie w tym czasie ogromnie rozszerzyły się horyzonty językoznawstwa. Pisze Milewski: „Europejczycy

\footnotetext{
193 W 1867 roku została wydana jego wersja kompletna.

194 Jego kolejne wydania ukazywały się w latach 1847 i 1868-1871.

195 A Reader on the Sanskrit Grammarians, red. J. F. Staal, Delhi 1985, s. 52 ("Whatever the extent of his knowledge, there was no one in Germany at the time who knew more Sanskrit than he did $^{n}$ ).
}

196 A. Heinz, Dzieje jezykoznawstwa w zarysie, Warszawa 1978, s. 25-26. 
szybko przyswoili sobie znacznie doskonalszą metodę opisu języka stosowaną przez gramatyków hinduskich, a ponadto zdobyli materiał językowy doskonale opracowany, który mogli porównać z pokrewnym historycznie materiałem greckim i łacińskim"197.

2. Theodor Benfey, Handbuch der Sanskritssprache zum Gebrauch für Vorlesungen und zum Selbsstudium

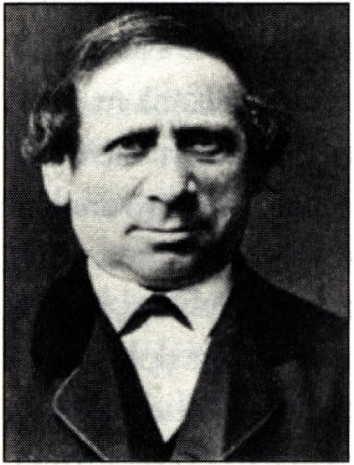

16. Theodor Benfey

Kolejnym badaczem, o którym warto choćby wspomnieć w kontekście europejskiej tradycji gramatyk sanskrytu, był Theodor Benfey (1809-1881). Był on, jak wielu indologów, z pierwszego wykształcenia filologiem klasycznym. Badacz niezwykle utalentowany językowo, wkrótce zainteresował się także sanskrytem. Jest autorem obszernej pracy poświęconej gramatyce sanskrytu zatytułowanej Handbuch der Sanskritsprache, zum Gebrauch für Vorlesungen und zum Selbsstudium. Erste Theile. Grammatik, wydanej w Lipsku, w dwóch tomach, w latach 1852-1853. Tom pierwszy to szczegółowy teoretyczny opis poszczególnych zagadnień gramatycznych przedstawianych w tradycyjnym, przyjętym już wcześniej w Europie porządku. Część opisowa poszerzona jest o wklejki zawierające zestawienia paradygmatów odmian. Zestawienia te są przejrzyste i z pewnością stanowiły ogromną pomoc w opanowaniu poszczególnych form przez korzystające $z$ jego gramatyki osoby, które starały się jak najlepiej poznać sanskryt. W swojej gramatyce Benfey, podobnie jak wielu innych autorów, używa w podawanych przykładach czcionek dewa-

197 T. Milewski, Jezykoznawstwo, Warszawa 1965, s. 33-34. 
nagari. Relatywnie często, w celu pogłębienia wyjaśnień, odwołuje się do form wedyjskich. Gramatyka ma zatem charakter po części porównawczo-historyczny. Można ją również niewątpliwie zaliczyć do gramatyk opisowych. W części poświęconej fonetyce podaje obszerny przykład fragmentu tekstu wedyjskiego pochodzącego z Rigwedy, w którym zaznaczone są, tak istotne w wedyjskim, akcenty. Od czasu do czasu wskazuje, w kontekście omawianych zjawisk gramatycznych, na teksty, w których można je znaleźć ${ }^{198}$. Uderza, że bardzo krótki, bo liczący niespełna pięć stron, jest fragment poświęcony ogólnemu omówieniu rdzeni sanskryckich. Bezpośrednio po nim, co nietypowe, jeśli wziąć pod uwagę kolejność przedstawiania zagadnień gramatycznych, Benfey omawia dosyć szczegółowo tematykę koniugacji pochodnych. W odróżnieniu od krótkiego rozdziału traktującego o rdzeniach czasownikowych bardzo znaczącą część poświęca tematowi złożeń. Omawia je w następującej kolejności: tatpurusza, karmadharaja, dwigu, bahuwrihi, awjajibhawa ${ }^{199}$. Benfey w samej gramatyce rzadko wspomina o źródłach, z których czerpał wiedzę na temat gramatyki sanskrytu. Takich informacji nie można także znaleźć we wstępie do jego książki. Można się o nich dowiedzieć szerzej dopiero z wyboru tekstów, który zawiera się w tomie drugim, zatytułowanym Chrestomathie aus Sanskritwerken. Zum Gebrauch für Vorlesungen und zum Selbststudium. Jest to obszerny wybór fragmentów tekstów, po którym następują relatywnie wyczerpujące objaśnienia odnoszące się do pewnych zjawisk gramatycznych występujących w tychże tekstach i najpewniej uważanych przez Benfeya za trudniejsze w interpretacji.

198 Czyni tu odnośniki do własnego wyboru fragmentów tekstów, który zawiera drugi tom jego gramatyki, bądź do chrestomatii O. Boehtlingka. 199 Autorzy gramatyk, podobnie jak Benfey, często nie uzasadniają, dlaczego przyjmują taką właśnie kolejność omawiania złożeń, a niewątpliwie powinien być to temat, któremu poświęca się szczególną uwagę ze względu na logiczność jego przedstawienia. 
Całość książki zamyka przegląd metrów wedyjskich i sanskryckich. Część druga to słowniczek sanskrycko-niemiecki. Każde $z$ haseł, poza podaniem niemieckiego odpowiednika wyrazu sanskryckiego zawiera odwołanie do odpowiedniego paragrafu w gramatyce, w którym dane słowo występuje. Wybór tekstów jest imponująco szeroki. Benfey dzieli swoją chrestomatię na trzy części, w których zamieszcza stopniowo coraz trudniejsze językowo teksty. Rozpoczyna od fragmentu z Mahabharaty, opowieści o Ambie (Ambopākhyāna), po którym następuje opowieść o porwaniu Sity pochodząca z Ramajany. Następnie, już w części drugiej, podaje wybór tekstów ze zbioru bajek, Pańczatantry (Pańcatantra), z księgi praw Manawadharmaśastry (Mānavadharmaśāstra), czy inaczej z Manusmriti (Manusmṛti), by potem włączyć do swego wyboru fragment Wasantawarnany (Vasantavarṇana). Trudność tekstów jest nadal stopniowana, jako że kolejnym fragmentem jest Nitiśataka (Nītiśataka) Bhartrihariego (Bhartṛhari) i dalej tekst zaliczany do epoki literatury kunsztownej, Kiratardżunija (Kirātārjunīya). W części trzeciej pomieszczone są fragmenty pochodzące $z$ tekstu Daśakumaraczarita (Daśakūmaracarita), przypisywanego słynnemu Dandinowi (Daṇ̣̂n), z Bhaszapariczczhedy (Bhāṣāpariccheda) oraz z Śiśupalawadhy (Śiśupālavadha) autorstwa Maghy (Māgha). Dodatek zawiera fragment tekstu natury historycznej, dzieła Kalhany (Kalhaṇa) zatytułowanego Radżatarangini (Rājataraṇgiṇi). Całość zamyka wybór kilku hymnów z Rigwedy. Należy stwierdzić, że już samym tym wyborem Benfey dał dowód swojego oczytania w literaturze sanskrytu. Z objaśnień, które dołącza, wynika, iż nieobce były mu nie tylko relatywnie łatwo dostępne prace $\mathrm{H}$. $\mathrm{H}$. Wilsona czy wybór tekstów autorstwa $\mathrm{O}$. Boehtlinga, ale także o wiele rzadsze dzieła A. Kühna, Goressiego, Kosegarten, Bohlena czy Haeberlina.

Także o metryce tekstów wedyjskich i sanskryckich pisze Benfey w sposób kompetentny. Po uwagach ogólnych omawia kolejno, w odniesieniu do metryki wedyjskiej, metrum gajatri (gāyatrī), usznih 
(uṣnih), anusztubh (anușțubh), prastarapankhi (prastārapankhi), wiradrupa (virāḍ̂ūpā), trisztubh (trișțubh), dżagati (jagatī) i pragatha (prāgātha). Przy omawianiu metrów sanskryckich rozpoczyna od epickiej śloki (śloka) i epickiego trisztubhu. Następnie pisze o metrum waitalija (vaitalìya), aupaczczhandasika (aupacchandasika) i puszpitagra (puṣpitāgrā). Przechodzi kolejno do metrów o nazwach arja (āryā), czy inaczej gatha (gāthā) w formie o nazwie szczegółowej pathja (pathyā). Pisze także o udgiti (udgītī), inaczej nazywanym wigadha (vigāthā) oraz giti (gīti) albo udgatha (udgāthā). Wreszcie na koniec omawia metrum indrawadżra (indravajrāa), upendrawadżra (upendravajrā), upadżati (upajāti), śalini (śâlin̄î), ratoddhata (ratoddhatā), wanśastha (vanśastha), drutawilambita (drutavilamita), dżaloddhatagati (jaloddhatagati), prabha (prabhā) o innej nazwie mandakini (mandākin̄i), pramitakszara (pramitākșarā), dżaladharamala (jaladharamālā), praharszini (praharṣin̄i), czandrika (ćandrikā) albo kszama (kṣamā), wasantatilaka (vasantatilakā), kutila (kuṭilā), malini (mālin̄î), śikharini (śikhariṇī), prithwi (pṛthvī), wanśapatrapatita (vanśapatrapatita), harini (hariṇī), mandakranta (mandākrāntā), śardulawikridita (śārdūlavikrị̣̄itā) i wreszcie sragdhara (sragdharā). Opisuje wszystkie metra, dzieląc je według grup ze względu na liczbę sylab i rozpisuje je ze względu na ich ciężkość bądź lekkość ${ }^{200}$. To pierwsze w tradycji europejskiej tak obszerne opracowanie tej tematyki, dołączone do samej gramatyki.

Lata 60. XIX wieku były okresem szczególnym w europejskiej tradycji powstawania kolejnych gramatyk sanskrytu. Ukazało się bowiem wtedy relatywnie dużo gramatyk pisanych, najprawdopodobniej niezależnie, przez znaczących indologów tej epoki. Nastąpił

$200 \mathrm{Na}$ dokładność i dobrą znajomość metryki wskazuje np. porównanie opisu Benfeya z omówieniem tej tematyki w książce autorstwa S. Cieślikowskiego, która ukazała się w roku 2016, czyli ponad 150 lat później (por. S. Cieślikowski, Teoria literatury w dawnych Indiach, Kraków 2016, s. 50-85). 
podobny do początku XIX wieku czas, kiedy wielu autorów decydowało się na pisanie i publikowanie własnych prac niezależnie od tych już istniejących bądź dopiero co wydanych czy właśnie pisanych. Co było tego powodem? Odpowiedzi może być co najmniej kilka. Jedną z nich może niewątpliwie być po prostu brak wiedzy o gramatykach innych autorów. Może był to także utrudniony kontakt pomiędzy poszczególnymi autorami wynikający z odległości w przestrzeni. Mogła być to także chęć kontynuowania tradycji lokalnej bądź tworzenia własnej czy zapis własnych metod uczenia studentów. Dzisiaj nie sposób udzielić jednoznacznej odpowiedzi.

\section{Adolf Friedrich Stenzler, Elementarbuch der Sanskrit- -Sprache. Grammatik, Texte, Woerterbuch}

W roku 1868 ukazała się jedna z gramatyk, która na długie lata miała stać się wzorem dla wielu innych wydawanych w różnych krajach europejskich. Była to gramatyka Adolfa Friedricha Stenzlera (18071887), zatytułowana Elementarbuch der Sanskrit-Sprache. Grammatik, Texte, Woorterbuch. Gramatyka ta nie tylko stała się wzorem dla innych, ale sama była także wielokrotnie wznawiana, stając się na długie lata kanonem w krajach niemieckojęzycznych. Wiele pokoleń indologów niemieckich wydawało kolejne jej edycje ${ }^{201}$. Wśród jego prac były $i$ te związane $z$ literaturą indyjską ${ }^{202}$. W początkowym okresie

201 A. F. Stenzler, Elementarbuch der Sanskrit-Sprache. Grammatik, Texte, Woerterbuch, wyd. 1 Breslau 1868; wyd. 2 1872; wyd. 3 1875; wyd. 4 1880; wyd. 5 1885; wyd. 6 1892; wyd. 7 1902; wyd. 8 1908; wyd. 9 1915; wyd. 10 1923; wyd. 11 1939; wyd. 12 1943; wyd. 13 1952; wyd. 14 1960; wyd. 15 1965; wyd. 16 1970; wyd. 17 1980; wyd. 18 1995. Być może powstały kolejne wydania.

${ }^{202}$ W szczególności dzieła Kalidasy - w roku 1832 w Londynie ukazało się jego łacińskie tłumaczenie Raghuwamśi zatytułowane Raghuvansa, 
studiów nauczycielem Stenzlera był Johann Gottfried Kosegarten (1792-1860). Później na Uniwersytecie Berlińskim stał się nim wielki Franz Bopp. Na zakończenie na uniwersytecie w Bonn Stenzler uczył się, czy raczej współpracował, z Augustem Wilhelmem Schleglem. Po uzyskaniu w roku 1829 doktoratu w Berlinie Adolf Stenzler celem odbycia dalszych studiów udał się do Paryża, gdzie spotykał się z Antoine'em-Léonardem de Chézym i Silvestre'em de Sacym. Można zatem stwierdzić, że miał kontakt z tymi największymi, współczesnymi mu sanskrytologami. Jego późniejsza podróż do Londynu pozwoliła mu na



17. Adolf Friedrich Stenzler pracę w bibliotece East India Company, gdzie z kolei miał dostęp do wielu indyjskich opracowań i do manuskryptów. Jego dalsze losy, od roku 1833, związane były z uniwersytetem w Breslau ${ }^{203}$. To właśnie tam uczył sanskrytu $\mathrm{i}$ językoznawstwa porównawczego ${ }^{204}$. Jednym z jego uczniów był Franz Kielhorn (1840-1908), autor A Grammar of the Sanskrit Language,

Kälidāsae carmen), a w 1838 inne jeszcze dzieło Kalidasy - Kumāra Sambhava, Kālidāsae carmen). Do Kalidasy powrócił jeszcze, wydając w roku 1847 niemieckie tłumaczenie jego dzieła Meghdūta zatytułowane Meghadūta, der Wolkenbote, Gedicht von Kalidasa opatrzone uwagami i słowniczkiem. Posiadamy polskie tłumaczenie tego dzieła autorstwa Joanny Sachse (por. Kalidasa, Meghadūta. Obłok - Posłańcem, Katowice 1994).

203 Obecnie Wrocław.

204 Uczył także arabskiego i perskiego, a od roku 1872 pracował w bibliotece, której zbiory wzbogacił o prace indologiczne. 
która ukazała się w roku 1870. Sama gramatyka Stenzlera jest pracą niezwykle syntetyczną i świetnie skonstruowaną. Jej 18. wydanie, którego podstawą była wersja w opracowaniu jednego z uczniów Stenzlera, wybitnego niemieckiego indologa Richarda Pischela (1849$1908)^{205}$, oraz K. F. Geldnera (1852-1929), a ostatecznie zredagowane przez Albrechta Wetzlera, składa się z trzech podstawowych części. Są to: gramatyka opisowa pomieszczona w rozdziałach składających się $\mathbf{z}$ jasno wydzielonych podrozdziałów poświęconych konkretnym zjawiskom gramatycznym, relatywnie bardzo krótki zbiór ćwiczeń uzupełniający poszczególne $z$ tych paragrafów oraz wybór tekstów (chrestomatia) i słowniczek kontekstowy ${ }^{206}$. Zagadnienia gramatyczne przedstawione są w kolejności właściwej wielu wcześniejszym opracowaniom europejskim, czyli po opisie fonetyki następuje przedstawienie kategorii nomen, potem verbum, podane są zasady tworzenia tematów rzeczownikowych i czasownikowych, wiadomości dotyczące złożeń (w kolejności: dwandwa, tatpurusza, karmadharaja, bahuwrihi, awjajihawa). Całość wykładu zawarta została na 75 stronach (!), a pozwala na poznanie gramatyki sanskrytu w stopniu wystarczającym na samodzielną lekturę tekstów. W wyborze tekstów znaleźć można też już klasyczny w tradycji europejskiej fragment opowieści o Nalu i Damajanti, fragmenty bajek pochodzących z Hitopadeśi, Pańczatantry i Kathasaritsagary, czyli teksty uważane za jedne z łatwiejszych. Kontekstowy słowniczek dołączony do gramatyki zawiera nie tylko sugerowane ekwiwalenty słów sanskryckich, ale także, od czasu do czasu, odwołania do poszczególnych fragmentów zawierających od-

205 R. Pischel swoją pracę doktorską poświęcił, niewątpliwie pozostając pod wpływem A. Stenzlera, różnym recenzjom Śakuntali Kalidasy.

206 Poszczególne wydania gramatyki Stenzlera różniły się przede wszysckim wyborem tekstów, co wskazuje na to, iż późniejsi redaktorzy, często bardzo wybitni, niemieccy indologowie, nie uważali, by należało cokolwiek zmieniać w samej gramatyce. 
powiedni materiał gramatyczny. Gramatyka Stenzlera zatem - mimo że opisowa w swej części wykładu teoretycznego - w uzupełnieniu o ćwiczenia, wybór tekstów i słowniczek może być także podręcznikiem, czyli może być używana pod opieką nauczyciela bądź nawet traktowana jako samouczek ${ }^{207}$.

Jako że nie sposób omówić szczegółowo wszystkich powstałych w drugiej połowie XIX wieku europejskich gramatyk sanskrytu ${ }^{208}$, przedstawiony zostanie jedynie krótki przegląd tych, które w ten czy inny sposób są różne od przedstawionych powyżej, a zatem przynajmniej co do formy przedstawienia materiału gramatycznego nowatorskie.

\section{Georg Bühler, Leitfaden für den Elementarkursus der Sanskrit}

Taką właśnie jest gramatyka autorstwa Georga Bühlera (1837-1898). Bühler był językoznawcą, indologiem, a dokładniej sanskrytologiem związanym z uniwersytetem we Wiedniu. Poza językami Indii uczył się też greki i łaciny, języka awestyjskiego, perskiego, ormiańskiego i arabskiego. Już to wskazuje, że był niesłychanie uzdolniony języ-

207 Gramatyka Stenzlera doczekała się tłumaczenia na język angielski (Primer of the Sanskrit language translated into English with some revision by Renate Söhnen, London 1992) oraz dokonanego przez Kresimira Krnica na język chorwacki (Samskrtska pocetnica). Andrzej Gawroński swoją gramatykę Podręcznik sanskrytu. Gramatyka, wypisy, objaśnienia słownik, według wszelkiego prawdopodobieństwa, napisał, także będąc pod wrażeniem gramatyki Stenzlera. Zachował bowiem jej strukturę i główne cechy kompozycji. Niewątpliwie autorski był jednak ilustrujący poszczególne zagadnienia gramatyczne wybór przykładów oraz wybór fragmentów tekstów, stanowiący znaczącą część książki.

${ }^{208}$ Ich spis znaleźć można w dołączonej do książki bibliografii gramatyk sanskrytu. 


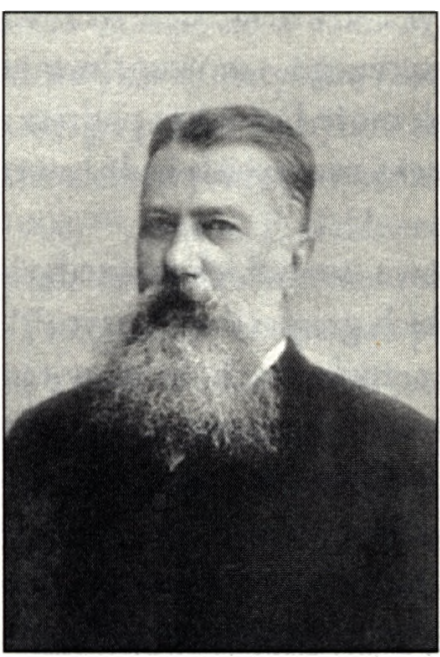

18. Georg Bühler kowo. Bühler w roku 1859 pojechał do Paryża, aby zająć się znajdującymi się tam sanskryckimi manuskryptami. Później badał też manuskrypty wedyjskie w bibliotece India Office w Oksfordzie. W roku 1863 udał się do Indii, gdzie objął katedrę języków orientalnych w Elphinstone College w Bombaju. Był członkiem bombajskiego oddziału Royal Asiatic Society. W Indiach przebywał kilkanaście lat, opanowując sanskryt także w mowie. Jedna $z$ jego książek poświęconych gramatyce sanskrytu ukazała się $\mathrm{w}$ Wiedniu w roku 1883. Zatytułowana była Leitfaden für den Elementarcursus des Sanskrit. Mit Übungsstücken und zwei Glossaren. Niewielka, bo licząca zaledwie 171 stron gramatyka niewątpliwie mogła stanowić dobrą podstawę do nauczenia się tego języka. Podobnie jak wiele innych gramatyk zawierała wklejki. Pierwsza z nich pokazywała alfabet dewanagari, zestaw najbardziej typowych ligatur i cyfry. Druga zestaw podstawowych reguł sandhi także przedstawionych w formie przejrzystej tabeli. Gramatyka Bühlera to składający się z 48 lekcji podręcznik stopniowej nauki. To novum w dziedzinie sposobów przekazywania wiedzy o gramatyce sanskrytu ${ }^{209}$. Do całości dołączone są dwa niezwykle skrótowe, kontekstowe słowniczki, sanskrycko-niemiecki i niemiecko-sanskrycki. Bardzo często słowa

209 W przeszłości pojawiały się już pojedyncze prace utrzymane w konwencji podręczników raczej niż gramatyk opisowych (np. podręcznik J. R. Ballantyne'a), ale były one niezwykle rzadkie i najprawdopodobniej, w przeciwieństwie do książki Bühlera, nie stały się popularne ani znane większej liczbie odbiorców. 
sanskryckie czy niemieckie mają tylko po jednym ekwiwalencie, co oczywiście nie odpowiada ich potencjalnemu zakresowi. Pytanie, na ile słowniczki kontekstowe stanowią dobrą pomoc w uczeniu się języka obcego, pozostaje otwarte do tej pory i nie ma na nie jednoznacznej odpowiedzi ${ }^{210}$. Ta właśnie gramatyka Bühlera stała się wzorem dla kilku późniejszych. W Stanach Zjednoczonych w roku 1885 ukazało się jej prawie dosłowne tłumaczenie ${ }^{211}$.

Na koniec przeglądu gramatyk, które powstały w ramach tradycji europejskiej w okresie od XVII-XIX wieku, warto wspomnieć o jeszcze jednej osobie. Arthur Anthony Macdonell to badacz, którego główną ideą było upraszczanie przedstawienia gramatyki sanskrytu w taki sposób, by uczynić ją jak najłatwiejszą w przyswajaniu przez studentów pragnących nauczyć się tego języka. Wydał w Londynie właśnie na przełomie XIX i XX wieku, bo dokładnie w roku 1901, gramatykę sanskrytu zatytułowaną Sanskrit Grammar for Beginners, w której takie właśnie uproszczenia proponował. Zawarł w niej dużo najrozmaitszego typu zestawień paradygmatów ułożonych w specjalnie zaprojektowanych tabelach. Uważał, że takich właśnie jak najłatwiej przyswajalnych i z tego względu m.in. okrojonych z wielu wiadomości, które nie mieściły się w opisie podstawowym gramatyki sanskrytu, brakuje. Był niewątpliwie jednym z najważniejszych prekursorów

211) Została ona przetłumaczona na język polski i jest jedną z niewielu prac dotyczących gramatyki sanskrytu dostępnych polskiemu odbiorcy (por. G. Bühler, Podręcznik sanskrytu, przeł. B. Baranowski, Warszawa 1977).

211 Tłumaczenie to funkcjonuje pod nazwiskiem Edwarda Delavana Perry'ego, mimo że dokładny tytuł brzmi Sanskrit Primer based on the Leitfaden für den Elementarcursus des Sanskrit of Professor Georg Bühler of Vienna. Podręcznik Bühlera w tym właśnie tłumaczeniu miał bardzo wiele wydań i reprintów m.in. w latach 1936, 1978, 1982, 1988, 1992 i in. i znany jest powszechnie jako podręcznik autorstwa Perry'ego. 
takiego nurtu w opisach gramatyki sanskrytu, w ramach którego, aby nie zniechęcać potencjalnych uczących się, autorzy starają się upraszczać skomplikowane zagadnienia i przedstawiać je jak najbardziej klarownie, w możliwie przystępny sposób.

Ten obejmujący wiek XIX okres rozwoju europejskiej tradycji gramatyk sanskrytu można określić czasem dominacji gramatyk pisanych przede wszystkim przez autorów niepozostających w bezpośrednim kontakcie z uczonymi indyjskimi. Jak napisano już wcześniej, wielu $z$ autorów nigdy nie odwiedziło Indii osobiście. Swoje prace opierali często na XVIII-wiecznych opracowaniach pisanych przez Europejczyków, którzy Indie odwiedzili i swoją wiedzę czerpali często od lokalnych informatorów. Ich, bardzo często świetne, dzieła można jednak z pewnością zaliczyć do wybitnych prac europejskiej tradycji gramatyk sanskrytu. $Z$ przedstawionego wyżej materiału jasno wynika, iż w liczącej sobie ponad 300 lat tradycji europejskich gramatyk sanskrytu powstałych w wiekach od XVII do XIX można wyróżnić kilka faz ze względu na sposoby jego opisywania i źródła, na których autorzy opierali swoją znajomość języka. Od powstałych w wiekach XVII i XVIII pisanych po łacinie dzieł tworzonych głównie przez misjonarzy, przez powstające od przełomu XVIII i XIX wieku gramatyki pisane przede wszystkim przez badaczy związanych $z$ działalnością Kompanii Wschodnioindyjskiej, aż po ogromną ilość prac XIX-wiecznych tworzonych często przez naukowców, którzy nigdy Indii osobiście nie odwiedzili. Niektóre $z$ gramatyk powstawały na podstawie mniej lub bardziej rozbudowanych źródeł wywodzących się bezpośrednio $z$ tradycji indyjskiej, podczas gdy inne bazowały na źródłach niebezpośrednich. $Z$ pewnością można stwierdzić, iż okres ten był bardzo istotny w poznawaniu tego języka starożytnych Indii przez Europejczyków, którzy musieli w tym celu przełamywać opór w udostępnianiu wiedzy o tym staroindyjskim języku, w którym często zapisywane były teksty święte. Jak wiadomo, znajomość tych 
ostatnich przez osoby do tego niepowołane nie była pożądana przez miejscowych znawców. To właśnie gramatyki tych badaczy sprawiły, że w kolejnych wiekach powstają oparte na nich coraz to nowsze opracowania. To one umożliwiają poznawanie sanskrytu współcześnie i sprawiają, że spotkanie z Innym staje się możliwe nie tylko na powierzchownym, podstawowym poziomie. 



\section{Część V}

\section{Gramatyki sanskrytu w języku polskim - XIX wiek}



1. Walenty Skorochód Majewski, Gramatyka mowy starożytnych Skuthów czyli Skalnych Gorali, Indo-Skythow, Indykow. Budhynow Herodota samskrytem czyli dokładna mowa zwaney

Pierwszą osobą, której niewątpliwie należy poświęcić uwagę, opisując polską tradycję prób opisów gramatyki sanskrytu, jest Walenty Skorochód Majewski (17641835). Ten erudyta, archiwista, z zawodu notariusz, historyk samouk i wykładowca w Szkole Kadetów w Warszawie starał się być także badaczem starożytności słowiańskich i związków słowiańsko-staroindyjskich. Przez wielu określany mianem sanskrytologa amatora, był kontrowersyjnym autorem licznych prac z najrozmaitszych dziedzin, w tym poświęconych sanskrytowi. Od 1809 roku był członkiem Królewskiego Warszaw-

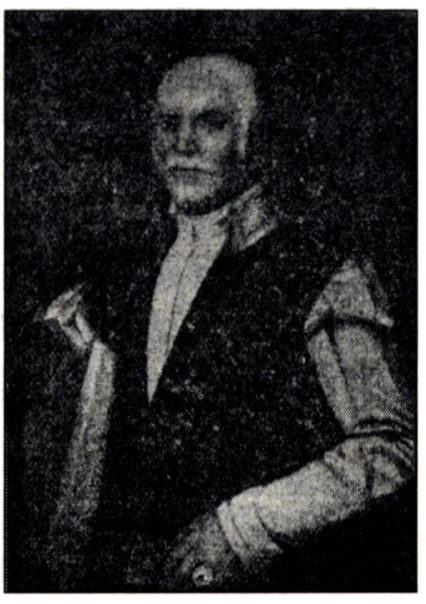

19. Walenty Skorochód Majewski skiego Towarzystwa Przyjaciół Nauk i, bez wątpienia, entuzjastą Indii. Był jednym z ostatnich metrykantów Rzeczypospolitej, a zarazem Członkiem Izby Poselskiej. Urodził się w licznej rodzinie drobnoszlacheckiej pod Grodnem na Podlasiu, we wsi Skorochód-Guzy. Był także absolwentem warszawskiego kolegium pijarskiego Collegium Nobilium (1785). Jako że już wtedy jego zainteresowania związane były z obcymi kulturami i ich językami, doskonalił znajomość tychże, 
korzystając z zasobów biblioteki pijarskiej i Biblioteki Załuskich ${ }^{212}$. Już w latach 1813-1816 Majewski wygłosił na posiedzeniach Warszawskiego Towarzystwa Przyjaciół Nauk serię wykładów, w ramach których starał się przekazywać znane mu informacje na temat języka starożytnych Indii, sanskrytu. W roku 1815 był to wykład zatytułowany Badania o pochodzeniu Stowian i ich jezyka, tudzież obyczajów i zwyczajów Indostanów, którzy zdaja sį mieć pewne podobieństwo, co do pierwiastków mowy i zwyczajów do dawnych Słowian. Starał się w nim wykazać związki słowiańsko-staroindyjskie ${ }^{213}$. Przedstawione podczas wykładu informacje Majewski przekazywał za uznanymi już w owym czasie za autorytety badaczami takimi jak np. William Jones. Od siebie dodawał kontrowersyjne porównania dotyczące sanskrytu i języka Słowian, w tym w szczególności języka polskiego.

Już w roku 1816, staraniem własnym, jako że miał w swoim mieszkaniu przy ulicy Świętojańskiej, w kamienicy Metrykantów Koronnych w Warszawie uruchomioną w roku 1815 pierwszą w Polsce drukarnię,

212 Te i bardziej szczegółowe dane dotyczące życiorysu Majewskiego można znaleźć w Polskim stowniku biograficznym (por. Polski stownik biograficzny, t. 19, Warszawa-Kraków 1974, s. 195-197). Autorem hasła jest Tadeusz Mencel. Krótka informacja dotycząca postaci Majewskiego jest także w rozdziale książki Towards a History of Linguistics in Poland. Autorem rozdziału jest Zdzisław Wąsik (Towards a History of Linguistics in Poland, Amsterdam 2001, s. 4). Jest także artykuł: B. Podolak, Walenty Skorochód Majewski zapomniany archiwista i pasjonat jgzyków wschodnich, "LingVaria” 2012, vol. 7, nr 1 (13), s. 183-194, oraz książka: A. Kuczkiewicz-Frás, Walentego Skorochoda Majewskiego Rozprawa o Stawianach $i$ ich pobratymcach, Kraków 2018.

213 Stanisław Staszic, który poprosił Majewskiego o opracowanie „rozprawki" o sanskrycie, tak mówił o nim w zagajeniu podczas jednego z posiedzeń Towarzystwa: „Kolega Majewski od wielu lat pracuje nad językami Azyi, szczególnie nad językiem Samskrytu Indyan; z tym dochodzi powinowactwa rozmaitych ludów, pokoleń i plemion”. 
w której użyto czcionek sanskryckich ${ }^{214}$, wydał książkę zatytułowaną O Sławianach $i$ ich Pobratymcach ${ }^{215}$. Majewski już wtedy wykazuje się znajomością niektórych z dostępnych w jego czasach prac uważanych za dobre źródła informacji o gramatyce sanskrytu. Jak się wydaje, znana była mu książka Paulinusa a Sancto Bartholomaeo Sidharubam, seu Grammatica sanscridamica. Cui accedit Dissertatio historico-critica in linguam Samscridamicam, vulgo Samscret dictam, wydana drukiem w Rzymie w roku 1790, która stanowiła, jak opisano wcześniej, w istocie raczej wstęp do gramatyki sanskrytu niż samą gramatykę. Znana była mu też wydana pięć lat później kolejna książka Paulinusa $V y$ acaram seu locupletissima Samscridamicae linguae institutio. Wydaje się, że nieobce były mu przynajmniej fragmenty wydanej w roku 1806 gramatyki W. Careya $A$ Grammar of the Sungskrit language, Composed from the works of the most esteemed Hindoo Grammarians. To which are added, Examples for the Exercise of the Student, and a Complete List of

214 Drukarnią tą kierował Tomasz Piętka.

215 Pełny tytuł: O Sławianach $i$ ich Pobratymcach. Częśi Isza. Obejmujq̨ca czytane na posiedzeniach Działowych w latach 1813. 1814. 1815. tudzież na Posiedzeniu Publicznem Towarzystwa Królewskiego Przyjaciół Nauk dnia 30 kwietnia 1816. r. Rozprawy o jezyku samskrytskim tudzież O literaturze Indyan w tymże į̨zyku, z przydatkiem wyciagu Gramatyki tegoż iqzyka, tablic rycin czyli pisma i liczbowych postaci. Osnowy wiersza bohatyrskiego pod nazwaniem Rama-Jana, wyciqgów z tegoż wiersza, Stowniczka, niemniey dwóch poprzedniczych rozpraw o Archiwach i umiejętności dyplomatyczney przez W. S. MAIEWSKIEGO Archiwistę i Pisarza Aktowego Królestwa Polskiego, Tow: Król: Prz: Nauk przybr: Członka PODLASIANINA. Avia Pieridum peragro loca, nullius ante Trita solo. - Lucretius Libr: IV. W Warszawie $1816 w$ Drukarni Wiktora Dąbrowskiego. Książka ta miała stanowić pierwszą część z zamierzonych czterech tomów dzieła, w którym Majewski planował opisy wać kolejne podobieństwa pomiędzy kulturami Słowian i, przede wszystkim, Indusów. Dokładne tytuły planowanych części podaje np. A. Kuczkiewicz-Fraś we wstępie do krytycznego wydania Rozprawy o Słowianach $i$ ich pobratymcach (A. Kuczkiewicz-Fraś, op. cit., s. XIV). 
the Dhatoos, or Roots oraz wydanej w 1810 roku w Kalkucie pracy H. P. Forstera Essay on the Principles of Sanskrit Grammar. Znał niektóre $z$ opracowań zamieszczanych na łamach „Asiatic Researches, or, Transactions of the Society instituted in Bengal for inquiring into the history and antiquities, the arts, sciences and literatures of Asia"216. Znał przemówienie, które wygłosił w 1815 roku francuski znawca sanskrytu A. L. de Chézy ${ }^{217}$. Opierał się zatem, przynajmniej po części, na źródłach wiarygodnych, chociaż pochodzących także od autorów niezajmujących się przede wszystkim gramatyką. Źródła te można zatem określić jako niewystarczające do dobrego poznania gramatyki sanskryckiej.

Książka Majewskiego, poza wstępem zatytułowanym Powody i droga postępowania, składa się z czterech części poświęconych zagadnieniom stricte gramatycznym ${ }^{218}$, z części piątej zawierającej streszczenie dwóch fragmentów Ramajany uczynione na podstawie, jak pisze sam Majewski, „ulotnego pisma”, którego autorem był de Chézy, z karty 253 $\mathrm{z}$ tomu 1 nAsiatic Researches" oraz z pomieszczonego $w_{n}$ Oddziale $\mathrm{V}^{n}$

216 Na przykład artykuł Williama Jonesa dotyczący literatury staroindyjskiej. Majewski sam pisze, iż miał dostęp jedynie do dwóch pierwszych tomów "Asiatic Researches".

217 We wstępie do swojej pracy pisze jeszcze, że jego informatorami byli: Anquetil-Duperron, Schütz, Adelung, Antoni Gotsch i Marcelle de Serres. W dalszej części wymienia jeszcze nazwiska Antona, Levesquesa, Karla Wilhelma Friedricha Schlegla i J. G. Eichhorna. Ten ostatni, mimo że był profesorem nauk orientalnych na uniwersytetach w Jenie i Getyndze, nie zajmował się jednak szczegółowo gramatyką sanskrytu. O pozostałych informatorach Majewskiego ( $z$ wyjątkiem Duperrona i Schlegla) trudno znaleźć szczegółowe informacje.

218 Majewski poszczególne części określa mianem ${ }_{n}$ Oddział I ${ }^{n},{ }_{n}$ Oddział II etc. 
Słowniczka samskryckich wyrazów z czytania zebranych ${ }^{219}$. Rozdział 1 zatytułowany jest Jezyk samskrytu, jego nazwiska, dzieje, rozciagłość. Rozdział 2 natomiast to część, w której Majewski pisze o budowie sanskrytu, poszczególnych częściach tejże budowy, stosunkach i składni wszystkich części, czyli przedstawia zarys gramatyki. Rozdział 3 ma tytuł Wyjątek z gramatyki samskrytu w mieście wschodnich Indii Serampur $w$ roku $1806 w$ angielskim $i$ samskrytskim jezykach wydanej. W rozdziale 4 natomiast jest mowa no literaturze dawnych Indian, a mianowicie w języku samskrytskim, podług podań P. Chesy, które w mianej dnia 15 stycznia 1815 r., przy objęciu Katedry Języka i Literatury Samskrytu mowie, umieścił" (taki właśnie posiada tytuł). I wreszcie „Oddział $\mathrm{V}^{n}$ Majewski tytułuje Osnowa wiersza bohatyrskiego Rama-Jana tudzież dwa uboczne obrazy (épisodes) tegoż wiersza. Ze względu na tematykę tej książki najistotniejsze są trzy pierwsze części pracy Majewskiego, jako że dotyczą one jego wiedzy w zakresie gramatyki sanskrytu. Znajomością gramatyk Paulinusa Majewski wykazuje się już na początku "Oddziału I". Paulinus bowiem podaje w Sidddharubam... znane i używane w czasach mu współczesnych nazwy na określenie języka starożytnych indyjskich ksiąg. Majewski podąża tu jego tropem. W dalszej części przeprowadza rozważania dotyczące sanskrytu jako źródła dla innych języków i dialektów indyjskich oraz obszarów, na których sanskryt miał być językiem dominującym. Stwierdza, że w czasach starożytnych zasięg sanskrytu obejmował Babilonię, Medię, Persję i rozciągał się aż do Konstantynopola. Pisze nawet, iż sanskryt dotarł do Włoch, Grecji i Niemiec. Był, jego zdaniem, powinowaty z językiem starożytnych Celtów. Podaje też, iż, jego zdaniem, to właśnie z sanskrytu pochodzą niektóre ze słów języka łacińskiego. Stara

219 Ciekawe byłoby szczegółowe przeanalizowanie źródeł, z których Majewski korzystał, przygotowując tę część swojej książki. To jednak wykracza poza ramy tego opracowania. 
się także dowieść, podając i analizując przykłady, że ślady, czy nawet bardzo bliskie podobieństwa, można znaleźć pomiędzy sanskrytem $\mathrm{i}$ innymi jeszcze językami Europy, w tym językami słowiańskimi, a pośród nich przede wszystkim językiem polskim. W 1818 roku Majewski wydał liczącą 90 stron pracę zatytułowaną Rozkład i treść dzieła o początku licznych Stawiańskich Narodów, tudzież każdego w szczególności. W roku 1828 wydał książkę poświęconą stricte gramatyce i zatytułowaną Gramatyka mowy starożyenych Skuthów, czyli Skalnych Gorali, Indo-Skythów, Indyków, Budhynów Herodota samskrytem, czyli dokładnq mowq zwaney ${ }^{220}$. W tej pracy, którą Majewski oparł na lekturze ${ }^{221}$ wymienionych w tytule autorów, w sposób dość chaotyczny stara się opisać gramatykę sanskrytu. Podaje informacje o alfabecie oraz dość niepełne wiadomości na temat fonetyki. Zamieszcza też fragment Prawidła Pisania i Wymawiania 222. Informacje uzupełnia o relatywnie dużo przykładów odmian wyrazów oraz tabele, w których porównuje pisma używane do zapisu sanskrytu (np. dewanagari, grantham, alfabet arabski). Włącza też do swojej książki rozdział o liczebnikach

220 Pełne brzmienie tytułu: Gramatyka mowy starożytnych Skuthów, czyli Skalnych Gorali, Indo-Skythów, Indyków, Budhynów Herodota samskrytem, czyli dokładna mowq zwaney. $Z$ oryginału Samskrytskiego przekładu PP. Colebrooke, Carey, Wilkins, Yates, Foster i innych, a szczegolniey, podtug poprawniejszego wydania P. Bopp w Berlinie dotad jeszcze nie ukończonego, przez Walentego Skorochód Maiewskiego Członka Izby Poselskiey do dialektu Polskiego $i$ innych Stawianskich zastosowana $i$ ulepszona. $Z$ przypisami. $Z$ całego dzieła zebranymi, naukę pisania, czytania, wymawiania i zrozumienia obeymujacymi $i z$ siedemnasto tablicami, odmiany pisania i rytowania głosek, ięzyków wschodnich, odmiany częśi mowy, wyciagi z różnych dzieł przedstawiajacemi.

${ }^{221}$ Wszystko wskazuje na to, że jednak jedynie pobieżnej lekturze.

222 Późniejszy polski autor gramatyki sanskryckiej Franciszek Malinowski, znający zresztą prace Majewskiego, omawia także Prawidła Pisania $i$ Wymawiania (por. F. Malinowski, Gramatyka sanskrytu porównanego z jezykiem starosłowiańskim i polskim, Poznań 1872). 
oraz przykłady poezji. Na zakończenie ponownie podaje, tym razem w formie tablic, wybrane reguły gramatyczne. Już z tego krótkiego przeglądu widać, jak nieuporządkowana i niepełna była ta gramatyka. Majewskiego z pewnością nie można było uznać za autorytet $w$ tej dziedzinie. Z lektury opracowań wynika, że Majewski starał się, przede wszystkim używając pracy Franciszka Boppa, przedstawić czytelnikowi polskiemu jakąś, choćby niewielką, ale jednak wiedzę o języku starożytnych Indii. Sam nie posiadał jednak wystarczającego przygotowania filologicznego, by pracę taką móc wykonać kompetentnie. Indie starożytne były w owych czasach niewątpliwie jednym $z$ obszarów ogromnego zainteresowania elit europejskich. Bardzo ważnym kluczem do poznawania ich przeszłości był z kolei sanskryt. Należy zatem oddać Majewskiemu, co należne, przyznając mu palmę pierwszeństwa w próbach zainteresowania polskiej publiczności sanskrytem. Był ni wątpliwie prekursorem polskich badań w tej dziedzinie. W roku 1830 wydał jeszcze pracę zatytułowaną Brahma-Waiwarta-Puranam... przez Podlasianina na polskie brzmienie wyrazów Samskrytu przepisana i do znaczenia $w$ jez $\gamma k u$ narodowym zbliżona - tekst sanskrycki, transkrypcja na jezyk polski. Była to rzecz oparta najprawdopodobniej na łacińskim przekładzie tej purany pióra Adolfa Stenzlera. Wydał też tłumaczenie, czy raczej parafrazę fragmentu Ramajany, czyli epizod o Jadżniadatcie (Yadźniadatta). Tu opierał się także nie na oryginalnym sanskrycie, ale na dostępnym mu przekładzie na język francuski. Za życia Majewski opublikował dziewięć książek i kilka artykułów. Wiele prac w rękopisach znalazło się po jego śmierci w Bibliotece Baworowskich we Lwowie. Niewydanych do tej pory tomów jest 21.

Majewski ze względu na swoje zainteresowania sprowadzał z zagranicy liczne dzieła współczesnych mu i wcześniejszych orientalistów. Jako że bardzo interesował się też kulturą, językami i literaturą oraz historią Słowian, także i te prace gromadził i sprowadzał z zagranicy. Książki te często potem tłumaczył i dodawał do nich własne komenta- 
rze. Zakupy te były z pewnością niezwykle kosztowne, co sprawiało, że Majewski często miewał problemy natury finansowej. Nie przeszkadzało mu to jednak poświęcać dużej części swoich zasobów na cele, które sam uważał za naukowe. Pisał Majewski:

[...] obeznałem się $z$ wielo prawdziwie wschodniemi dialektami, a szczególnie z mową-matką starożytnych Azyi i Europy Skuthów czyli Indo-Skytów, wielką łączność $z$ ięzykami i dialektami starożytnych i teraźnieyszych Słowian Europy maiącą [...],

pokazując po raz wtóry, co było jednym z najważniejszych powodów, dla których interesował się sanskrytem ${ }^{223}$.

Próbując działać jako językoznawca komparatysta, zestawiał wyrazy sanskryckie z polskimi. Czynił to jednak tylko na podstawie zewnętrznego podobieństwa, bez żadnej podstawy naukowej. Tak było, gdy uważał imię indyjskiego władcy ${ }_{n} \mathrm{Kuru}^{n}$ za odpowiednik polskiego słowa "król”, sanskryckiego "para" (wyższy, inny, lepszy) - za równoważnik słowa polskiego "parny", czy wreszcie gdy słowo

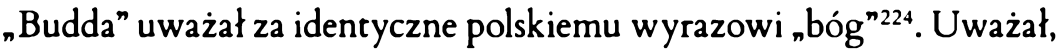
że wiele dalszych przykładów można byłoby znaleźć, poszukując ich w sposób niejako "mechaniczny". Drukował w swoich pismach tabele alfabetów, wyrazy sanskryckie i całe wersety w sanskrycie, będąc także w tym nowatorem na polskim terenie. O Majewskim nie sposób nie napisać, gdy chce się pokazać, jaki był poziom wiedzy o gramatyce sanskrytu w Polsce na początku XIX wieku. Był to niewątpliwie czas zdobywania zaledwie wstępnych informacji, uzyskiwanych droga pośrednią, pochodzących jednakże od orientalistów europejskich, którzy w owym czasie opisywali już gramatykę sanskrytu w sposób

223 Cyt. za: B. Podolak, op. cit., s. 187.

22t Por. M. Wielińska, Walenty Skorochód Majewski. The Precursor of Polish Indological Studies, „Rocznik Orientalistyczny” 2007, vol. 60, z. 2, s. 163. 
kompetentny, precyzyjny i naukowy. Chwała zatem Majewskiemu za to, że mimo chęci szerzenia teorii o panslawizmie najprawdopodobniej przynajmniej był jednym z tych, którzy rozbudzali zainteresowanie kulturą starożytnych Indii i sanskrytem.

\section{Franciszek Xawery Malinowski, Gramatyka sanskrytu} porównanego z jezykiem starosłowianskim i polskim

Franciszek Xawery Malinowski urodził się w 1807 lub 1808 roku w Gołubiu, miasteczku położonym na terenach Prus Zachodnich ${ }^{225}$. Już we wczesnej młodości wykazywał zainteresowanie językami, ucząc się łaciny, greki i hebrajskiego. Jego dalsze życie, a w szczególności życie naukowe, związane było z pracami natury ściśle filologicznej, a precyzyjnie językoznawczej. Interesowała go przede wszystkim filologia polska, którą studiował na Uniwersytecie Poznańskim ${ }^{226}$. W szeroko pojętym obszarze jego zainteresowań mieściły się też

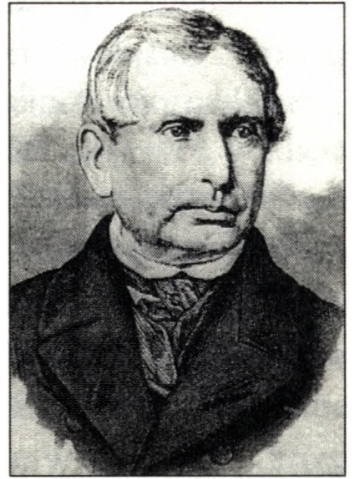

20. Franciszek Xawery

Malinowski

225 Różne źródła podają różne daty jego urodzenia.

226 Jedną z jego pierwszych prac była rozprawa zatytułowana Zasady i prawidła pisowni polskiej. Inna, wydana w roku 1863, to Krytyczny poglad na zasady głosowni znanych autorowi gramatyk polskich. W tej ostatniej, biorąc pod uwagę 14 gramatyk języka polskiego, Malinowski ocenia krytycznie opracowanie jej głosowni. Fonetyka była działem gramatyki, której dużo miejsca poświęcał we wszystkich swoich następnych pracach. $Z$ kolei w latach 1869-1870 wydał w Poznaniu książkę zatytułowaną Krytyczno-porównawcza gramalyka jezzka polskiego z dzisiejszego stanowiska lingwistyki porównawczej, a w 1873 roku, także w Poznaniu, jej uzupełnienie Dodatek do gramatyki jezyka polskiego. 
inne języki słowiańskie. Jego szczególną uwagę zdobył system fonetyczny języków słowiańskich, indoeuropejskich i semickich. Interesował się też historią, dialektami i ortografią języka polskiego ${ }^{227}$. Jego propozycje z zakresu fonetyki i wynikającego z tego zapisu poszczególnych głosek „Abecadła wszechsłowiańskiego”, jak chciał, by go nazywano, były mocno krytykowane przez badaczy mu współczesnych. „Znaleźli się groźni przeciwnicy, którzy cały [zaproponowany przez niego - I. M.] system w najdrobniejszych zaczepili szczegółach [...] ostateczny zaś szturm przypuścił p. Cegielski [...]" - pisał L. Rzepecki ${ }^{228}$. Znajdował jednak też obrońców, np. uczonego tej miary co J. Baudouin de Courtenay. Ten ostatni pisał bowiem:

Gramatyka ks. Malinowskiego jest dziełem nie natchnienia, lecz długiej i sumiennej pracy. Nie spuszczał się on na Ducha św., ale obok pilnego badania pomników języka starał się, o ile mógł, przyswoić sobie zasady nowszego językoznawstwa... Gramatyka więc ta zaznajamia choć w części z ndzisiejszym stanowiskiem" lingwistyki porównawczej ${ }^{229}$.

Ostatecznie jednak de Courtenay konkludował:

Tak więc abecadło wszechsłowiańskie Malinowskiego, jeżeli rości sobie pretensyją do skończoności i nieomylności, dla praktycznego użytku jest za "uczone", dla naukowych zaś celów zanadto ubogie, pomimo że ogólna zasada jest jak najzupełniej „naukowa" ${ }^{\text {230 }}$.

Szczęściem Malinowskiego było to, iż podczas jego studiów i pracy Poznań był jednym z miejsc, gdzie spotkały się, poza wymienionymi

227 Por. M. Guz, Franciszek Ksawery Malinowski als Wissenschaftler, „Prace Językoznawcze" 1999, vol. 1, s. 33.

${ }_{228}$ Cyt. za: M. Guz, op. cit., s. 36.

229 Ibidem, s. 37.

230 Ibidem. 
do tej pory, postaci tej miary naukowej co K. Libelt, A. Cieszkowski czy uczeń F. Boppa, H. Cegielski ${ }^{231}$. W tym okresie Malinowski zainteresował się też sanskrytem. Był współzałożycielem powstałego w roku 1857 Poznańskiego Towarzystwa Przyjaciół Nauk, a w roku 1873 został wybrany na członka Akademii Umiejętności w Krakowie. W roku 1829 wstąpił do seminarium duchownego, a w 1838 przyjął święcenia kapłańskie, co niewątpliwie miało duży wpływ na całe jego późniejsze życie. Między innymi także na to, że relatywnie często zmieniał miejsce zamieszkania. Zmarł w roku 1881 w Komornikach pod Poznaniem.

Jednym z dokonań Franciszka Xawerego Malinowskiego była także, ważna ze względu na tradycję polskich opisów sanskrytu, wydana w roku 1872 w Poznaniu Gramatyka sanskrytu porównanego z jezykiem starosłowiańskim i polskim. Jej podtytuł brzmiał $\mathrm{Na}$ podstawie sanskryckiej gramatyki Franciszka Boppa. Już tytuł wskazuje zatem na główne źródło informacji, na którym oparł się Malinowski. W przedmowie sam pisze, iż za taką podstawę przyjął gramatyki Boppa wydane odpowiednio w latach $1834,1845^{232}$ i wreszcie w roku 1863, które to gramatyki, jak pisze Malinowski, były streszczeniem wydanych wcześniej, bo w roku 1827 po niemiecku i w roku 1832 po łacinie ${ }^{233}$. Zamierzeniem Malinowskiego było udostępnienie wiadomości o san-

231 Ten ostatni opublikował już w roku 1842 niedocenianą z początku przez badaczy mu współczesnych, a opartą na dogłębnych studiach rozprawę O stowie polskim i jego konjugacyach. Dopiero Malinowski był tym, który pracę tę, gdy ukazała się ponownie 10 lat później, ocenił bardzo wysoko. 232 Tytuł gramatyki Boppa wydanej w roku 1845 w Berlinie przez wydawnictwo Nicolaischen Buchhandlung brzmiał Kritische Grammatik der Sanskrita-Sprache in kürzerer Fassung. Była ona zatem gramatyką skróconą. ${ }^{233}$ F. X. Malinowski, Gramatyka sanskrytu, Poznań 1872. Malinowski podaje tytuły tych gramatyk. Wydaną w roku 1827 po niemiecku Ausführliches Lehrgebäude, a wydaną w roku 1832 po łacinie Grammatica critica, Przedmowa, s. XIII. 
skrycie polskim czytelnikom. Pisze o tym w swojej książce, porównując swój cel z tym, który towarzyszył, jego zdaniem, samemu Boppowi:

Autor nasz, jako profesor Lingwistyki Porównawczej przy uniwersytecie berlińskim pisząc niniejszą gramatikę, zamierzał ułatwić naukę sanskritu swojim słuchaczom, my zaś chcąc swemi uwagami uczynić tę jego ważną pracę przystępniejszą dla chcących się obeznać s tym językiem bez pomocy nauczyciela $[. . .]^{234}$.

Jest jasne, że celem, który wyznaczył sobie autor, było wykazanie, iż zarówno język starosłowiański, jak i, w szczególności, język polski mają wiele wspólnego z sanskrytem ${ }^{235}$.

Malinowski wspomina o swoim polskim poprzedniku Walentym Skorochodzie-Majewskim. Nie poświęca mu jednak sporo uwagi. Dowodem na to, że znał jego prace, jest wzmianka we wstępie do samej gramatyki, w której pisze: „Na tym polu badań językowych s pomiędzy ziomków naszych mam tylko jednego poprzednika w osobie. Ś. p. Walentego Skorochoda Majewskiego"236. Gramatyka Malinowskiego składa się z następujących rozdziałów: Grafika i Fonetika (Prawopis i Wygłaszanie) ${ }^{237}$, w ramach którego po szczegółowym opisie poszczególnych dźwięków i znaków sanskryckich zamieszcza, jak sam pisze, nzestawienie spółgłosek sanskryckich z polskiemi (w formie tabeli)". W rozdziale drugim omawia Prawidła Miłodźwį̨ku, podając zarówno reguły ogólne, jak i szczegółowe (np. pisze O niektórych

${ }^{234}$ F. X. Malinowski, Gramatyka sanskrytu, s. 390.

235 Szczegółowe informacje dotyczące tego zagadnienia można znaleźć w artykule autorki książki (por. I. Milewska, Pan-slavism ideology as shown in Sanskrit grammars in Polish, „Wratislaviensium Studia Classica” 2017-2018, vol. 37-38, nr 6-7, s. 292-301).

236 F. X. Malinowski, Gramatyka sanskrytu porównanego z jezykiem starosłowiańskim i polskim, Wstęp, s. XIV.

237 Tutaj i w tym, co następuje, zachowuję pisownię oryginału. 
rzadkich wsuwkach). Rozdział kolejny tytułuje O Pierwiastkach i $\mathrm{Na}$ głoskach. Dziwi, że jest to rozdział relatywnie krótki, liczy bowiem tylko 10 stron. Bardzo ogólnie omawia w nim temat rdzeni czasownikowych, skupiając się na możliwych prefiksach modyfikujących ich treść ${ }^{238}$. Listę tych ostatnich podaje w porządku alfabetycznym (wg alfabetu dewanagari). To jego autorski dodatek. Dalej następuje rozdział zatytułowany Jimię. Temat, czyli Pień. Warto tu przytoczyć pierwsze zdanie tego rozdziału dla zobrazowania sposobu i stylistyki opisu zagadnień gramatycznych pióra Malinowskiego:

Indijscy Grammaticy pojmująjimiona (tak rzeczowniki, jak przymiotniki, zaimki i liczebniki) w jich stanie bezwzględnym, niezawisłym od wszelkich odnoszeń skłonnikowych, i pozbawionym wszelkich skłonnikowych końcówek, i przyjmują następnie formę główną, albo pniową, do której mianownik wraz s pobocznemi skłonnikami mają jako wyrazy pochodne, czyli pochodniki ${ }^{239}$.

Jasno widać, iż jest to tekst współcześnie trudny w lekturze, ale niepozbawiony wdzięku ze względu na używane w nim nazwy poszczególnych form gramatycznych ${ }^{240}$. Omawia typowe paradygmaty odmian, ale także Nieprawidłowe, czyli nieforemne skłanianie. Temu tematowi poświęca wiele uwagi. Słowo to tytuł i temat kolejnego rozdziału, który został podzielony na części takie jak Czasy $i$ Tr $\gamma b \gamma$,

23\% Ciekawostką jest, iż w celu ułatwienia zapoznania się z nimi grupuje je w formie zestawienia, w ramach którego podana jest ich liczba, pisząc, że np. tych zaczynających się od ${ } \mathrm{a}^{n}$ jest dziewięć, od $\mathrm{p}^{n}$ pięć itd. Ich łączną liczbę podaje jako 21.

239 F. X. Malinowski, op. cit., s. 89.

240 "Skłonniki" to oczywiście przypadki, których Malinowski wylicza osiem, odróżniając je od słowiańskich siedmiu (por. ibidem, s. 93). Zmienia też niektóre z nazw przypadków, np. „celownikowi” nadaje drugą nazwę "odbieracz" (por. ibidem, s. 121). 
Podział słów na dziesięć szeregów, Urabianie czasów wyłącznych, Czasy powszechne, czyli spólne, Reduplikowany przeszły, Przeszły omówny, Przyszły jimiesłowowy, Proszacy, Przyszły positkowy, Warunkowy, Laet ${ }^{2+1}$ $i$ Wieloforemny przeszły przyczynkowy. W ramach tego rozdziału podaje zarówno reguły ogólne w formie treści dotyczącej poszczególnych zagadnień, jak i paradygmaty odmian (tytułowane często mianem "Wzorzec"). Kolejny rozdział zatytułowany jest Słowa Pochodne. Malinowski dookreśla tytuł w następujący sposób: „Do słów pochodnych należą bierne, przyczynowe, pożądliwe, natężające i jimionowe"242. Kolejna część to Słowotwórstwo, Wyrazy Złożone oraz Wyrazy Nieodmienne. Pisze dalej o stronie biernej, podając stosowne paradygmaty. Dalej, w rozdziale Słowotwórstwo, omawia formy, które określa jako "Pierwotne wyrazy”, podając szczegółowe reguły tworzenia od nich rozmaitych wyrazów i form. W bardzo obszernym i szczegółowym spisie treści zatytułowanym Spis Treści kriticznego opracowania Gramatiki Sanskritu Boppa, Malinowski oddaje uznawanemu przez siebie za prawdziwego autora należny mu szacunek. Podaje zatem, na jakie paragrafy dzieli się dzieło Boppa, przedstawione czytelnikowi w jego tłumaczeniu i opracowaniu ${ }^{243}$. Mimo ogromnej dokładności tego spisu treści jego autor usprawiedliwia się dodatkowo:

Spis ten jest skrócony, nie zawiera bowiem ani treści Uwag Autora, ani treści Uwag Tłumacza, których ostatnich jest kilkaset. Gdybyśmy

241 Jak pisze Malinowski, „Tak się nazywa u indijskich gramatyków pewien tryb, właściwy wedijskiemu narzeczu, obejmujący więcej czasów i używający się w znaczeniu mogącego, proszącego i rozkazującego, przeto też postawione przez indijskich gramatyków formy pierwszych osób rozkazującego należą w samej rzeczy do trybu Łaet ${ }^{\text {n }}$ (ibidem, s. 374).

242 Ibidem, s. 383.

243 Spis ten obejmuje strony $559-581$. 
byli chcieli jedne i drugie zamieścić, byłby ten spis urósł do objętości całego kilku arkuszowego Zeszytu, co przechodziło siły nakładu ${ }^{244}$.

Gramatyka zaopatrzona jest w Przykład Jqzyka, w ramach którego Malinowski analizuje pieśń 9 i 10 opowieści o Nalu i Damajanti (ich imiona podaje odpowiednio jako Nałus i Damajantī). Malinowski podaje poszczególne strof $y^{245} \mathrm{w}$ alfabecie dewanagari i $\mathrm{w}$ transkryp$\mathrm{cji}^{246}$. Następnie poddaje je analizie gramatyczno-etymologicznej. Jak sam pisze o tym:

Po obeznaniu się z zasadami Gramatiki, najwłaściwszą jest drogą do gruntownego i umiejętnego obeznania się z obcym a zwłaszcza umarłym językiem takowy rozbiór gramatyczno-etymologiczny. Jest to prawda s początku praca nudna, oschła i powolna, lecz jim dłużej się i troskliwiej zajmiemy takową, tym mniej nas trudzić będzie i coraz więcej czuć będziemy wewnętrznego zadowolenia ze znajomości tak blizko spokrewnionego ze słowiańską mową języka ${ }^{247}$.

Część gramatyki poświęcona tej praktycznej umiejętności zajmuje 32 strony. W gramatyce Boppa ${ }^{248}$ ta część, zatytułowana Sprachprobe, jest znacznie krótsza. To jedynie 9 stron, na których Bopp podaje krótki fragment opowieści o Nalu i Damajanti w alfabecie dewanagari oraz w transkrypcji ${ }^{249}$. Widać zatem jasno, że Malinowski wykazał się w swojej pracy dużym wkładem własnym. Nie było to z pewnością

244 F. X. Malinowski, op. cit., s. 559.

245 W jego nazewnictwie "wrotki".

246 Dokonanej zgodnie $z$ regułami, które sam przyjął.

247 F. X. Malinowski, op. cit., s. 526.

248 F. Bopp, Kritische Grammatik der Sanskrita-Sprache in kürzerer Fassung, Berlin 1845.

249 Według ustalonych przez siebie zasad, różnych od tych, które przyjął Malinowski. 
jedynie bierne tłumaczenie oryginału ${ }^{250}$. Niewątpliwie gramatyka F. X. Malinowskiego, szczególnie gdy porównać ją z opracowaniami Walentego Skorochoda-Majewskiego, jest pracą, którą można określić jako dzieło naukowe. Malinowski nie tylko był z wykształcenia filologiem, co dawało mu znajomość metodologii pracy językoznawczej, ale na dodatek oparł swoją książkę na starannie wybranych i przepracowanych przez siebie źródłach. To właśnie jego można nazwać prawdziwym prekursorem polskiej tradycji gramatyk sanskrytu.

Wiek XIX kończył się zatem i w naszej części Europy optymistycznie $w$ dziedzinie prac naukowych nie tylko nad kulturą staroindyjską, ale także nad sanskrytem, w znaczeniu opracowań dotyczących jego gramatyki.

Warto na koniec wspomnieć jeszcze o kilku osobach, które mimo że nie były autorami gramatyk sanskrytu, zapisały się w sposób znaczący w dziejach polskich XIX-wiecznych prac związanych z szeroko pojętą kulturą, w tym literaturą dawnych Indii. W szczególności warto zwrócić na nie uwagę ze względu na to, że wpisały się w europejską tradycję poznawania opowieści o Nalu i Damajanti jako jednej z pierwszych, z którymi warto zapoznać polskiego czytelnika. Pierwszą z tych osób był Jan Leciejewski (1854-1929).

Leciejewski był studentem tak Uniwersytetu Wrocławskiego, jak i Wiedeńskiego. To na tym ostatnim uzyskał habilitację. W roku 1877 zamieszkał we Lwowie, gdzie wkrótce został docentem prywatnym Uniwersytetu Lwowskiego. Był osobą, która jako pierwsza pokusiła się o tłumaczenie na język polski pełnego tekstu opowieści o Nalu i Damajanti. Przekład swój zatytułował Nal. Powieść staroindyjska.

250 Poza pracami wydrukowanymi za życia Malinowskiego w rękopisach zostały jeszcze inne, m.in. Gramatyka jezyka starosłowiańskiego, Gramatyka jezyka litewskiego czy Gramatyka jezyka małoruskiego oraz Stownik jezyka litewskiego. Swoje prace często opierał na dziełach innych uczonych, każdorazowo jednak podawał podstawy, na których je tworzył. 
Został on wydany w roku $1885^{251}$. Było to tłumaczenie dokonane bezpośrednio z oryginału. Dowodem na to, iż Leciejewski za podstawę wziął właśnie oryginał, jest filologiczna analiza tekstu. $\mathrm{Na}$ rzecz tej tezy można także przywołać jego własne słowa, w których stwierdza, co następuje: „Tłómaczyłem zaś wedle oryginału $[\ldots]^{\text {n252 }}$. Sanskryt nie był jedynym polem zainteresowania Leciejewskiego. Jego badania obejmowały też dzieła szeroko pojętej słowiańszczyzny. W roku 1899 opu-



21. Jan Leciejewski blikował Gramatykę jezzka polskiego. W roku 1906 z kolei wydał książkę zatytułowaną Runy i runiczne pomniki słowiańskie. Był zatem Leciejewski postacią, która wpisywała się w polską tradycję łączenia studiów polonistycznych ze studiami nad kulturą, literaturą i językiem starożytnych Indii. Mimo że dzisiaj jest badaczem zapomnianym, warto o nim pisać choćby ze względu na pierwszeństwo właśnie w dziele tłumaczenia bezpośredniego.

Kolejną ważną osobą w polskiej tradycji badań nad literaturą staroindyjską, a co za tym idzie - nierozłącznie wiążącą się znajomością języka, był Antoni Lange (1862-1929). Lange to znany powszechnie młodopolski poeta i popularyzator literatur wschodnich. Wydał on pośród innych tekstów także i ten zatytułowany Pieśn o Nalu i Damajanti. Baśn staroindyjska z ksiqg Mahabharaty. W podtytule można znaleźć informację, że przekładu z sanskrytu dokonał Antoni

251 J. Lecieje wski, Nal. Powieść staroindyjska, „Ateneum" 1885, vol. 2, z. 2, s. $273-324$.

252 Ibidem, s. 274. 
Lange. Rzecz opublikowana została po raz pierwszy w roku $1906^{253}$. Można by zatem sądzić i wielokrotnie taka informacja jest podawana, iż to właśnie on był pierwszym polskim tłumaczem całej opowieści o Nalu i Damajanti dokonanej bezpośrednio z sanskrytu. Nie jest jednak pewne, czy Lange poznał sanskryt w stopniu wystarczającym, by można było uznać jego wersję opowieści za tłumaczenie wprost $z$ oryginału. Bezpieczniej jest zatem uznać je za parafrazę niż za przekład ${ }^{254}$. Nie sposób jednak odmówić

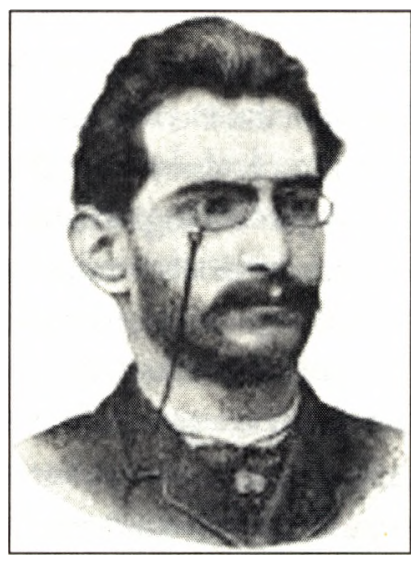

22. Antoni Lange

mu ogromnego oczytania we współczesnej mu literaturze fachowej w rozmaitych językach europejskich.

Polska tradycja zainteresowania się tekstami literatury staroindyjskiej w sposób niebezpośredni sięga zresztą, jak sygnalizowano już na początku książki, czasów jeszcze wcześniejszych. Już bowiem w roku 1901 Julian Adolf Święcicki (1848/1850-1932) w swojej książce zaty-

253 A. La nge, Pieśn o Nalu i Damajanti. Baśń staroindyjska z ksiag Mahabharaty, przekład z sanskrytu, przedmowa A. Lange, Warszawa 1906. Lange włączył także fragment tekstu tej opowieści w streszczenie Mahabharaty, które zostało opublikowane w 1911 roku (A. La nge, Epos indyjskie. Vyasa. Mahabharala, [w:] Zbiór arcydziet (poezyi epickiej wszystkich czasów i narodów $w$ streszczeniach i wyciagach ułożył $A$. Lange), Brody 1911).

${ }^{254} \mathrm{Na}$ taki wniosek wskazują np. liczne fragmenty, w których Lange nieprecyzyjnie oddaje wyrazy czy wyrażenia sanskryckie. Niewątpliwie, jak na swoje czasy, wykazywał się dobrą znajomością kultury literackiej starożytnych Indii. Czy jednak pochodziła ona z samodzielnej lektury tekstów oryginalnych? Na to pytanie nie można udzielić jednoznacznej odpowiedzi. 
tułowanej Historya literatura indyjskiej ${ }^{255}$, poświęciwszy jeden z rozdziałów Mahabharacie, zamieścił w nim także streszczenie opowieści o Nalu i Damajanti, uznając, że informacja o tym eposie byłaby niepełna, gdyby nie wspomnieć o historiach mających już tak długą tradycję w europejskich tłumaczeniach fragmentów Mahabharaty. Pisał bowiem Święcicki: „Ta historya o Nalu i żonie jego Damayanti należy do najpiękniejszych klejnotów literatury indyjskiej. To też tłumaczono ją po wielekroć razy na różne języki europejskie ${ }^{250}$. Święcicki

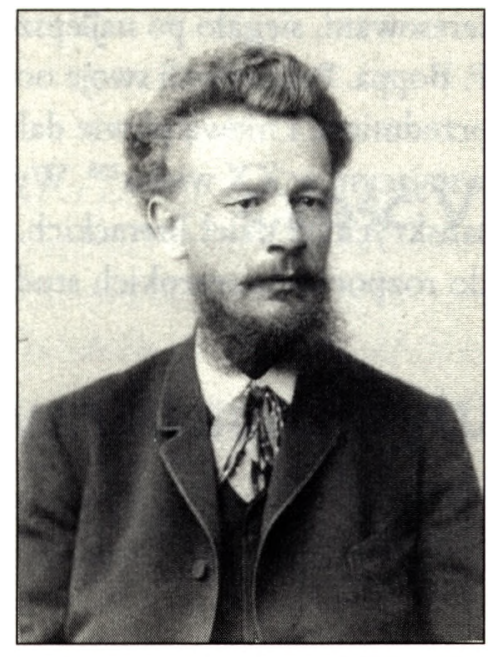

23. Julian Adolf Święcicki

wymienia w swojej książce źródła, z których korzystał, przygotowując ją. Pokazuje to jego relatywnie bardzo duże oczytanie w literaturze przedmiotu. Wzmiankuje nawet współczesne mu europejskie gramatyki sanskrytu. Wymienia bowiem m.in. prace F. Boppa, F. Kielhorna, R. Ficka czy O. Boehtlingka, pokrótce je charakteryzując ${ }^{257}$.

Polska nowożytna tradycja gramatyk sanskrytu wpisywała się w jej europejskie nurty. Tych niewielu, którzy byli sanskrytem zain-

255 Książka ta została wydana jako czwarty tom, w ramach stworzonej przez Swięcickiego serii Historya Literatury Powszechnej w Monografijach.

256 J. A. Św ięcick i, Historya literatury indyjskiej, Warszawa 1901, s. 234.

257 O gramatyce Kielhorna pisze: „Jest to gramatyka treściwa i gruntowna, ale dla początkujących niezdatna do użytku, gdyż autor podaje wszystkie przykłady czcionkami sanskryckiemi bez transkrypcyin, natomiast o książce Ficka: „Jest to mała gramatyka dla samouków, w której wszystkie przykłady drukowane są czcionkami łacińskimi” (ibidem, s. 450). Wskazuje to niewątpliwie, iż autor znał co najmniej te gramatyki. 
teresowani, sięgało po najlepsze wzorce, przede wszystkim po dzieła F. Boppa. Pokazywali swoje oczytanie we współczesnej im literaturze przedmiotu i niewątpliwie dali dobry początek polskim pracom powstającym w XX wieku ${ }^{258}$. Wykazywali także znajomość przekładów sanskryckich dzieł literackich, co niewątpliwie stanowiło podstawę do rozpoczęcia szerokich studiów nad starożytną kulturą indyjską.

258 W XX wieku wydane zostały napisane $w$ języku polskim gramatyki sanskrytu autorstwa Andrzeja Gawrońskiego i Marka Mejora (A. Gaw roń ski, Podręcznik sanskrytu. Gramatyka, wypisy, objaśnienia, słownik, Kraków 1932; wyd. 2 Lublin 1985; wyd. 3 poprawione Warszawa 2004; M. Mejor, Sanskryt, Warszawa 2000; wyd. 2 Warszawa 2004). 
Część VI

Wybrane słowniki sanskrytu 

a koniec należy dodać parę słów o nowożytnej europejskiej tradycji słowników sanskrytu. Ponieważ temat ten jest bardzo obszerny, zostaną podane tylko podstawowe informacje dotyczące wybranych słowników. Powstanie słowników dwujęzycznych było faktem niezwykle ważnym, po pierwsze dlatego, że stały się one jednym z podstawowych narzędzi pracy każdego parającego się sanskrytem. Po drugie, te wydane jako pierwsze były często źródłem dla kolejnych, powstających w późniejszej tradycji. Wreszcie powód trzeci ich krótkiego omówienia to popularność, którą cieszą się także obecnie.

Horace Hayman Wilson już w roku 1819 wydał w Kalkucie obszerny, bo liczący ponad tysiąc stron, słownik zatytułowany $A$ Dictionary in Sanskrit and English, translated, amended, and enlarged from an original compilation, prepared by learned natives for the College of Fort William ${ }^{259}$. Był to słownik dwujęzyczny, którego głównym celem było umożliwienie dokonywania tłumaczeń tekstów sanskryckich na język angielski. Jego autor dodawał często w poszczególnych hasłach objaśnienia natury gramatycznej, w tym, co ciekawe, jako pierwszą informację sygnalizował typ złożenia, jeśli w określonym haśle miało to, jego zdaniem, znaczenie ${ }^{260}$. Nie stało się to normą w późniejszych

259 Jego drugie, poszerzone wydanie ukazało się także w Kalkucie, w roku 1832; kolejne równocześnie w Londynie i Berlinie w roku 1856. To ostatnie zostało poprawione i rozszerzone przez Theodora Goldstückera. Jego tytuł brzmiał $A$ Dictionary, Sanskrit and English, extended and improved from the second edition of the dictionary of Professor $H$. H. Wilson with his sanction and concurrence. Together with A Supplement, Grammatical Appendices and an Index, serving as An English-Sanskrit Vocabulary.

260 Od czasu do czasu zamieszczał też, podając taką czy inną informację, znak zapytania, co wskazuje na jego krytyczny stosunek do własnych propozycji. 
słownikach. Wilson podawał też w swoim słowniku krótkie wiadomości dotyczące mitologii. Zostały one oparte przede wszystkim na tekstach puran, które były jednym z działów literatury szczególnie mu bliskich $^{261}$. Zdarzały się też odwołania do któregoś z eposów. Z kolei niezbyt często podawał lokalizację słów w określonych tekstach. Tym niemniej przywoływał ogromną gamę źródeł. Były to zarówno dzieła wedyjskie, jak i literatura gramatyczna, arytmetyczna, prawnicza czy filozoficzna. Podawał też odniesienia do literatury komentatorskiej, w szczególności dotyczącej tekstów sanskryckiej literatury klasycznej, ale także traktatów gramatycznych. Jak wynika choćby $z$ tego, co napisano powyżej, wykazywał się znajomością imponującej ilości tekstów. Pytaniem otwartym pozostaje, na ile teksty te były mu znane z samodzielnej lektury, a na ile korzystał z pomocy miejscowych znawców. Na ten temat nie można znaleźć, poza ogólnikowymi, pewnych informacji. Wilson nie sugerował ewentualnych znaczeń kontekstowych poszczególnych wyrazów, chociaż zdarzało mu się cytować krótkie fragmenty oryginalnych tekstów sanskryckich, w których dane słowa wystąpiły. Ze względu na miejsce pierwszego wydania i na swoją obszerność nie było to dzieło szeroko znane w Europie. Korzystali z niego jednak niewątpliwie badacze brytyjscy, którzy przygotowywali w Indiach prace natury gramatycznej, w tym w szczególności ci, którzy pisali własne gramatyki sanskrytu czy słowniki. Z pomocą słownika H. H. Wilsona czytano także dzieła literatury sanskryckiej, które jako pierwsze były przybliżane publiczności europejskiej. O nim właśnie Monier Monier-Williams - twórca powstałych później, szeroko znanych słowników - pisał tak: ${ }_{n}$ The Sanskrit and English Dictionary of Professor H. H. Wilson is, indeed, too well known as

261 W roku 1897 ukazało się w Kalkucie jego dzieło właśnie im poświęcone i zatytułowane Puranas, or an account of their contents and nature, które stało się dla wielu źródłem podstawowym ogólnych informacji o nich. 
one of the best lexicons in any language to require comment $[\ldots]^{n 262}$ (nSłownik sanskrycko-angielski autorstwa profesora $\mathrm{H}$. $\mathrm{H}$. Wilsona jest z pewnością dziełem zbyt dobrze znanym, jako jeden z najlepszych leksykonów powstałych w jakimkolwiek z języków, by wymagał on komentarzy").

Już rok później, także w Kalkucie, wydał swój znacznie mniej szczegółowy słownik William Yates. Był on zatytułowany $A$ Sunscrit vocabulary; containing the nouns, adjectives, verbs, and indeclinable particles most frequently occurring

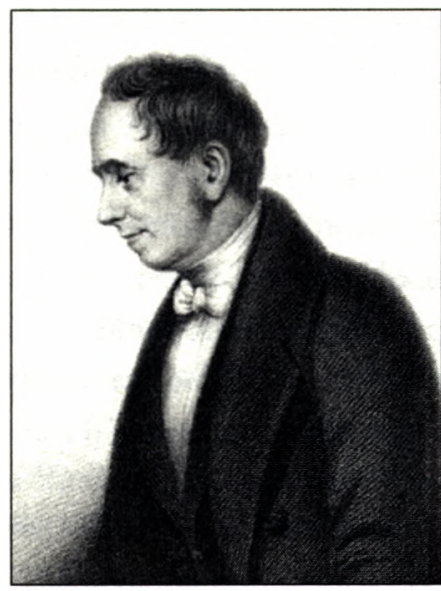

24. William Yates in the Sunscrit language, arranged in grammatical order with explanations in Bengalee and English. Już sam tytuł wskazuje, że był to słownik stawiający sobie za główny cel objaśnianie znaczenia ze względu na przynależność do poszczególnych kategorii gramatycznych. Warte podkreślenia jest także i to, że autor wykazał się znajomością zarówno sanskrytu, jak i języka bengalskiego.

Niedługo potem, bo już w roku 1830, swoje dzieło zatytułowane Glossarium Sanscritum, którego bardzo rozbudowana wersja o tytule Glossarium Sanscritum in quo omnes radices et vocabula usitatissima explicantur et cum vocalibus graecis, latinis, germanicis, lithuanicis, slavicis, celticis comparantur ukazała się 17 lat później, wydał Franz Bopp. Był to słownik, który można nazwać komparatystycznym, jako że jego głównym celem było przedstawienie słownictwa sanskryckiego

262 M. Monier-Williams, A Dictionary. English and Sanskrit, Delhi 1989, s. II. 
w porównaniu ze słownictwem europejskim. Miał zatem charakter całkiem odmienny od słowników omówionych powyżej.

Pierwszy słownik angielsko-sanskrycki ukazał się z kolei $\mathbf{w}$ roku $1851 \mathrm{w}$ Londynie. Zatytułowany został A Dictionary, English and Sanskrit, a jego autorem był Monier Monier-Williams. Było to dzieło bardzo ważne również dlatego, że jako pierwsze było szeroko znane publiczności europejskiej ${ }^{263}$. Autor dedykował swoją pracę dyrektorom Kompanii Wschodnioindyjskiej. Zakładał jej charakter jak przede wszystkim użytkowy. Pisał:

[...] żaden student, który będąc uczony tej umiejętności, nie jest w stanie dokonać tłumaczenia fragmentu tekstu pochodzącego $z$ języka angielskiego na któryśs z języków orientalnych, nie powinien zostać uznany za wystarczająco wykwalifikowanego do służby w Indiach. Jeśli taki wymóg znajomości języków mówionych jest stawiany adeptom, o ileż ważniejsza jest znajomość klasycznego języka Indii, sanskrytu. Jest on bowiem w znacznie bliższej relacji do tych języków mówionych niż greka i łacina ${ }^{264}$.

Student taki musi jednak mieć odpowiednie do tej nauki narzędzia. Właśnie jednym z nich jest oferowany mu słownik. Monier-Williams pisze, że praca nad słownikiem zajęła mu osiem lat, podczas których

203 Jest ono wydawane do tej pory; np. w 1976 roku ukazało się w Delhi jego czwarte wydanie. Później często pojawia się ono także w formie reprintu (np. 1982, 1989).

${ }^{264}$ M. Monier-Willia ms, op. cit., s. I ( ${ }_{n}[\ldots]$ no student shall be pronounced qualified for Indian service untill he can make an intelligible translation from an English passage into the Oriental languages in whic he has been instructed. And if this requirement has been wisely made, as a test of scholarshipin the spoken dialects, much more ha sit been so been made in regard to Sanskrit, the classical language of India, which bear a far closer relations to those dialects than Greek and Latin bear to the living languages of Europe ${ }^{n}$ ). 
przepisywał $w$ porządku alfabetycznym wszystkie słowa angielskie wraz z ich synonimami sanskryckimi, które zawierał słownik Amarakośa, w wydaniu przygotowanym przez H. T. Colebrooke'a. Następnie przepisywał wszystkie angielskie słowa, które zawierał słownik angielsko-łaciński autorstwa J. E. Riddle'a ${ }^{265}$. W ten sposób stworzył rodzaj tezaurusa, który stał się podstawą dalszej pracy. Dodał słowa z Hitopadeśi, z wyboru fragmentów tekstów z Mahabharat $y$ wydanych przez E. H. Johnstona, któremu zresztą dziękuje za pomoc w tworzeniu słownika w sposób szczególny. Fragmenty z Meghaduty, z antologii Ch. Lassena i rdzenie z pracy Westergaarda Radicaes Linguae Sanscritae uzupełniały wcześniej wybrane słownictwo. Monier-Williams wykorzystał także jako źródło słownik H. H. Wilsona, biorąc z niego jednak tylko te słowa, które nie miały angielskich odpowiedników bądź nie pojawiły się do tej pory. Monier-Williams w dalszej części wstępu opisuje jeszcze bardziej szczegółowo swoje kolejne działania, np. korzystanie ze słowników języków indyjskich, takich jak słownik języka marathi J. T. Moleswortha, czy $z$ innych jeszcze sanskryckich tekstów oryginalnych. Monier-Williams uzupełnił też treść swojego słownika o wiadomości pochodzące z Glossarium Sanskritum Franza Boppa. $\mathrm{Na}$ końcu wspomina też o pracach R. Ballantyne'a i W. Yatesa ${ }^{266}$. To rzadki przypadek, kiedy autor słownika opisuje szczegółowo metodę jego przygotowywania. Pisze o licznych decyzjach, które musiał podejmować w przypadkach, kiedy słowo angielskie miało wiele synonimów, ale także odpowiedników, które nie do końca pokrywały się zakresem swego znaczenia. Pisze o włączeniu informacji natury mitologicznej, religijnej czy ogólnokulturowej i o wahaniach w wyborze i możliwym ograniczaniu tychże. Kolejne problemy, któ-

265 A Complete English-Latin Dictionary; for the use of Colleges and Schools, London 1938.

260 M. Monier-Williams, op. cit., s. IV-V. 
rym musiał stawić czoło, dotyczyły uwzględnienia określonej liczby rdzeni czasownikowych. Mimo tych wszystkich problemów autorowi udało się sprawić, by poszczególne hasła były przedstawiane bardzo klarownie. Często słowa angielskie mają po kilka odpowiedników, czasem opatrzonych dokładniejszymi uwagami co do ich możliwego zastosowania. Słownik jest używany do tej pory i wykorzystywany do różnych celów, niekoniecznie do dokonywania tłumaczeń z języka angielskiego na sanskryt, co, jak pisał autor, było przecież jednym $\mathbf{z}$ jego podstawowych celów.

Wkrótce po nim zaczęły ukazywać się pierwsze tomy słownika uważanego do tej pory za jeden z najbardziej szczegółowych w znaczeniu materiału językowego, który był brany pod uwagę przy jego powstawaniu. Był to słownik zatytułowany Sanskrit Woerterbuch ${ }^{267}$, od miejsca wydania nazywany powszechnie słownikiem petersburskim. Jego autorami byli: Otto von Boehtlingk (1815-1904), uczeń m.in. Augusta Wilhelma von Schlegla, Christiana Lassena i Franza Boppa, oraz Rudolph von Roth (1821-1895), który uczył się języków orientalnych oraz badał manuskrypty sanskryckie na uniwersytetach w Paryżu, Londynie i Oksfordzie.



25. Otto von Boehtlingk

267 Jego pełen tytuł brzmi Sanskrit-Woerterbuch herausgegeben von der Kaiserlichen Akademie der Wissenschaften bearbeitet von Otto Boehtlingk und Rudolph Roth. 
Słownik ich autorstwa ukazywał się stopniowo w latach 1855-1875 208. Także ten słownik ukazuje się współcześnie. Jego pierwsze wydanie indyjskie miało miejsce w roku 1990. Już w przedmowie autorzy przywołują jako ważne dla nich dzieła powstałe wcześniej. Był to przede wszystkim słownik $\mathrm{H}$. $\mathrm{H}$. Wilsona, ale także $A$ Dictionary, Bengali and Sanskrit, czyli relatywnie mało znany słownik autorstwa G. C. Haughtona. Piszą także o znanych im teoretycznych pracach H. Colebrooke'a. Wspominają o kilku jeszcze innych indologach, m.in.

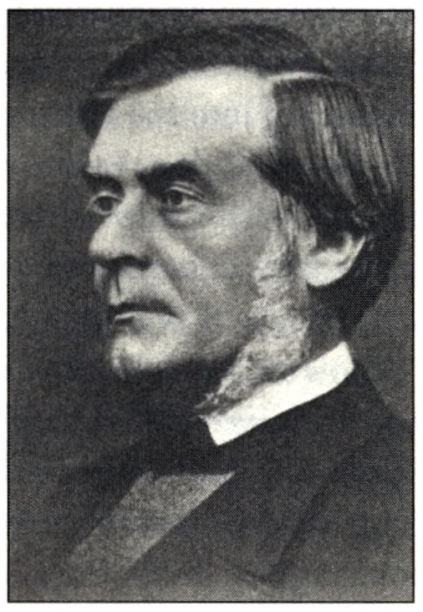

26. Rudolph von Roth

o Franzu Boppie, Theodorze Benfeyu

czy Adolfie Stenzlerze, których dzieła niesłownikowej natury wykorzystywali w pracach nad swoim słownikiem. A. Stenzler pomagał im np. w dziedzinie obszernego słownictwa zawartego w Manusmrti (Manusmriti). Autorzy słownika petersburskiego piszą, że starali się korzystać podczas przygotowywania go przede wszystkim $z$ dostępnych im wydań krytycznych poszczególnych tekstów. Teksty te obejmowały zarówno literaturę wedyjską, epicką, w tym w szczególności Bhagawadgite, purany, dzieła Kalidasy, Bhartrihariego, teksty bajek, literaturę prawniczą, teksty $z$ antologii Christiana Lassena, jak i inne, nie zawsze wymieniane $z$ nazwy. Uwzględniali też informacje pochodzące ze wspominanego już wcześniej jako często tłumaczonego i opracowywanego przez badaczy europejskich indyjskiego słownika

208 Skrócone wydanie tego słownika zatytułowane Sanskrit-Woerterbuch in kurzerer Fassung, bearbeitet O. von Boehtlingk ukazywało się w Petersburgu w latach 1879-1889. 
Amarakośa ${ }^{209}$. Wzmiankowali o tekstach pochodzących $\mathrm{z}_{n}$ Asiatick Researches, or Transactions of the Society instituted in Bengal, for inquiering into the History and Antiquities, the Arts, Sciences, and Literature". Zakres źródeł nie ograniczał się zatem tylko do tekstów oryginalnych i słowników. Nie sposób wymienić wszystkich, dość stwierdzić, że sama lista źródeł liczy pięć stron, na których źródła wymieniane są w dwóch kolumnach ${ }^{270}$.

Słownik Boehtlingka i Rotha składa się z siedmiu tomów, zawierających niezwykle szczegółowo opracowane hasła, w których objaśniane są w języku niemieckim poszczególne wyrazy. Poza podaniem gamy znaczeń słownik zawiera m.in. informacje na temat etymologii poszczególnych słów, ich lokalizacji w wielu tekstach, z częstym podaniem ich potencjalnie możliwego znaczenia kontekstowego oraz $\mathbf{z}$ wiadomościami natury gramatycznej polegającymi najczęściej na określaniu poszczególnych form gramatycznych. Jego niewątpliwą zaletą jest to, że często wskazuje na konkretne znaczenie danego słowa w tekście literackim, a także zawiera długie cytaty z tych właśnie dzieł. Słownik Boehtlingka i Rotha był i jest nadal szeroko ceniony. Przez niektórych badaczy współczesnych, takich jak np. Maurice Winternitz, jest on uważany za największe europejskie osiągnięcie indologiczne wieku XIX. Za dzieło, z którego czerpali wszyscy piszący słowniki później271.

Monier Monier-Williams, autor słownika angielsko-sanskryckiego, w roku 1872 stworzył także słownik sanskrycko-angielski, który od momentu jego wydania stał się jednym z podstawowych narzędzi towarzyszących każdemu z zajmujących się sanskrytem. Słownik ten

269 Wydanie z przedmową H. T. Colebrooke’a.

270 O. Boehtlingk, R. Roth, Sanskrit Woerterbuch, vol. 1, Petersburg 1855, s. VIII-XII.

271 M. Winternitz, A History of Sanskrit Literature, vol. 1, Delhi 1990, s. 19. 


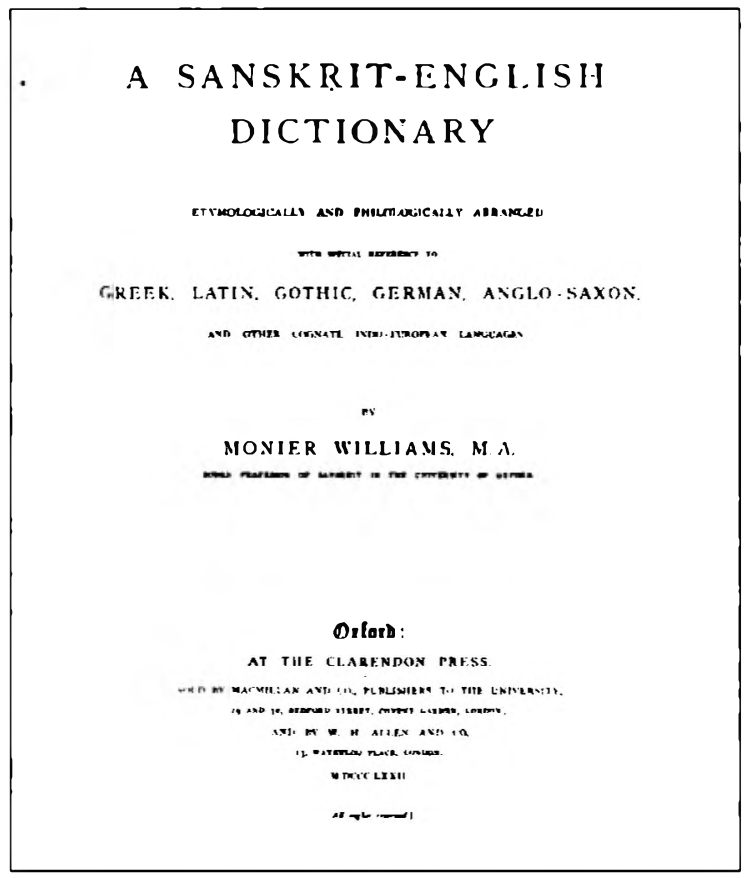

27. Monier Monier-Williams, $A$ Sanskrit-English

Dictionary, karta tytułowa

ukazywał się potem wielokrotnie, by wreszcie stać się dostępnym w formie internetowej. Jego pochodzące z 1899 roku rozszerzone i poprawione wydanie zatytułowane $A$ Sanskrit-English Dictionary etymologically and philologically arranged with special reference to Greek, Latin, Gothic, German, Anglo-Saxon and other cognate Indo-European languages zostało opracowane we współpracy $z$ innymi jeszcze badaczami.

M. Monier-Williams wymienia we wstępie najważniejszych z nich oraz osoby, które w ten czy inny sposób pomagały mu przy jego tworzeniu. Byli to profesorowie F. Kielhorn, H. Brunnhofer, A. E. Gough, E. L. Hogarth, E. Leumann, uczeń Georga Bühlera - dr Schönberg, Carl Cappeller oraz jego asystent dr Blau. Widać jasno, że dopiero 
wspólny wysiłek mógł przynieść tak świetne owoce, były to przecież czasy, kiedy brane pod uwagę teksty musiały być czytane, a słowa w nich używane zapamiętywane w kontekstach przez badaczy, których nie wspomagały ani obecnie dostępne komputerowe zbiory, ani komputerowa pamięć. To właśnie wydanie stało się podstawą późniejszych wersji słownika ${ }^{272}$. Monier-Williams wspomina o niezwykłej pomocy, której udzielali mu także lokalni znawcy sanskrytu. Pisze:

[...] kiedykolwiek spotykałem się z miejscowymi uczonymi myślicielami, byli oni skłonni rozmawiać ze mną w sanskrycie czy w językach danego regionu. Wyjaśniali mi trudne fragmenty wiedzy czy to dotyczącej sanskrytu, czy języków lokalnych. Mówili o miejscowych literaturach, religiach czy o filozofii. Ku mojemu zdumieniu działo się tak nie tylko w miastach czy w miasteczkach, ale także na wsi ${ }^{273}$.

O tym samym mówi w dalszej części wstępu, pisząc dodatkowo, co następuje:

Pozwoliło mi to na podawanie wielu pożytecznych informacji, których nie sposób znaleźć w innych pracach [na temat gramatyki sanskrytu - 1. M.] oraz uniknięciu wielu błędów czynionych przez sanskrytologów, którzy posiadali tylko książkową wiedzę na temat sanskrytu ${ }^{274}$.

272 M. Monier-Williams, op. cit., s. XXXI.

273 Ibidem, s. VII ( ${ }_{n}[\ldots]$ on each occasion I met to my surprise with learned and thoughtful natives - not only in the cities and towns, but even in remote villages - able and willing to converse with me in Sanskrit, as well as in their vernaculars, and to explain difficult points in their languages, literatures, religions and philosophies").

274 Ibidem, s. XVI ("It has enabled me to give much useful information not found in other works, and to avoid many mistakes made by Sanskritists who have only book - knowledge of India"). 
Monier-Williams, co można stwierdzić z pewnością, był użytkownikiem sanskrytu mówionego. Na to wskazywało zresztą już wcześniej przygotowanie przez niego słownika angielsko-sanskryckiego. Jest także poświadczone, iż znał język bengalski. Już na początku wstępu wyraża wielkie uznanie dla pracy O. Boehtlingka i R. Rotha. To z ich siedmiotomowego słownika w ogromnej mierze korzystał, przygotowując własny ${ }^{275}$. Pisze także, iż źródłem jego informacji był słownik H. H. Wilsona ${ }^{276}$. W dalszej części wstępu dodaje, że wiele skorzystał także z lektury wydanej w roku 1840 w Bonn pracy Nielsa Ludwiga Westergaarda Radices linguae sanscritae ad decreta grammaticorum definivit atque copia exemplorum exquisitionum illustravit oraz z przygotowanego przez amerykańskiego językoznawç̨ W. D. Whitneya zestawienia form gramatycznych, czyli z jego Index of Roots, Verb-forms and Primary Derivatives $^{277}$. Monier-Williams określa jasno cele, dla których napisał swój słownik. Pisze, iż starał się stworzyć pracę charakteryzującą się jak najwyższym możliwym poziomem naukowości. Pracę, która dzięki klarowności swej konstrukcji pokazywałaby w sposób możliwie jasny strukturę języka wraz z etymologią poszczególnych wyrazów w jej zestawieniu z językami Europy. Chciał stworzyć słownik, który byłby wystarczający pod względem zawartości, ale zarazem możliwy do zamknięcia w jednym tomie, a dzięki temu łatwy w użyciu. Mimo tego założenia słownik liczy dużo ponad tysiąc stron. W zamierzeniu autora słownik miał być pomocą tak dla sanskrytologów czy, szerzej, indologów, jak i dla językoznawców ${ }^{278}$. Niewątpliwie takiego słownika brakowało. Mimo iż zamierzał stworzyć słownik relatywnie niezbyt obszerny, to ze względu na obfitość słownictwa sanskryckiego

\footnotetext{
275 Ibidem, s. V.

276 Ibidem, s. XI, XXX.

277 Ibidem, s. XV.

278 Ibidem, s. VIII.
} 
w pierwszym wydaniu postanowił uwzględnić około 120000 słów, i prostych, i złożonych, do których w kolejnych wydaniach dodał jeszcze $60000^{279}$. We wstępie opisuje szczegółowo, jakie dodatkowe informacje natury kulturowej starał się zawrzeć w poszczególnych hasłach. Dotyczyły one zarówno mitologii, religii, jak i filozofii. Opierał swoje wyjaśnienia na jak największej liczbie dostępnych mu tekstów. Najchętniej używał tych w opracowaniach krytycznych. Jako o ciekawostce można tu wspomnieć także i o tym, że wyjaśnia powody, dla których włączył do słownika wyrazy, które sam określił jako nindecent words" ( słowa nieprzyzwoite"). Otóż uważa, że tego typu słowa muszą znaleźć się $\mathbf{w}$ dobrze przygotowanym słowniku, bowiem w sanskrycie $i \mathrm{w}$ innych językach orientalnych występują one w wielu tekstach i nie są obarczone znaczeniami, które we współczesnych mu czasach nie mieściły się w używanym powszechnie słownictwie ze względu na europejską pruderię tej epoki ${ }^{280}$. Dobrym przykładem takiej pruderii może być np. pochodzące z roku 1912 bezimienne polskie tłumaczenie Kamasutry Watsjajany, w którym niektóre $\mathrm{z}$ rozdziałów podane są jedynie $\mathrm{w}$ wersji łacińskiej ${ }^{281}$. Jak wspomniano, M. Monier-Williams starał się oprzeć swój słownik na

279 Ibidem, s. VII, XVI.

280 Ibidem, s. XVI.

${ }^{281}$ Kämasūtra Vātsyāyany. Indyjska Ars Amatoria. Wraz z kompletnym komentarzem (Jayamańgalā) Yaśodhary, oryginał w sanskrycie, Lwów 1922. Jest to tłumaczenie dokonane nie wprost z sanskrytu, ale z niemieckiego przekładu Richarda Schmidta, które zostało wydane w Berlinie siedem lat wcześniej, w roku 1915. Również i ta praca pozostawiała niektóre z rozdziałów jedynie w wersji łacińskiej. Podobnie rzecz miała się w Anglii, gdzie wydano Kamasutrę w roku 1883, a jej tłumacze Richard Burton i F. F. Arbuthnot woleli pozostać bezimienni. Obszerniejsze informacje na temat dziejów europejskich, pruderyjnych tłumaczeń tego dzieła można znaleźć m.in. we wstępie do przekładu Kamasutry autorstwa M. K. Byrskiego (por. Kamasutra, czyli traktat o mitowaniu / Watsjajana Mallanaga, przeł. z oryg. sanskryckiego, przedm., 
jak największej liczbie tekstów. Lista autorów i prac, które brał pod uwagę podczas jego przygotowywania, jest naprawdę imponująca ${ }^{282}$. Można tu znaleźć tak najważniejsze dzieła okresu wedyjskiego, jak i te należące do sanskrytu epickiego czy klasycznego. Z zakresu tekstów wedyjskich autor wylicza m.in. te podstawowe, czyli Rigwedę, Atharwawedę i Samawedę, liczne brahmany, aranjaki oraz upaniszady. $\mathrm{Z}$ dzieł epickich mamy tu zarówno oba eposy, Mahabharatę i Ramajan̨̨, jak i liczne purany, a nawet upapurany. Są też niektóre z dzieł Kalidasy, np. Kumarasambhawa (Kumārasambhava), Meghaduta czy Wikramorwaśi (Vikramorvaśī) oraz Śiśupalavadha (Siśupālavadha), by podać tylko kilka przykładów. Są prace z zakresu indyjskiej leksykografii, prawa, filozofii i poetyki. Jednym słowem, źródła są niezwykle różnorodne i pokazują naprawdę wyśmienitą znajomość staroindyjskiej tradycji.

W 1893 roku ukazał się na europejskim rynku słownik odmienny, gdyż bardzo uproszczony. Przygotował go i wydał Arthur A. Macdonell. Zatytułował go A Practical Sanskrit Dictionary. With Transliteration, Accentuation, and Etymological Analysis Throughout. Autor, zgodnie z tytułem, miał przede wszystkim na uwadze właśnie względy praktyczne. Starał się, by jego słownik był relatywnie krótki. Ostatecznie liczy około 400 stron, co jest objętością umiarkowaną, jeśli porównać go $z$ innymi, wcześniej wydanymi słownikami. Słownik Macdonella wydawany był wielokrotnie i jest powszechnie używany do tej pory ${ }^{283}$. Poszczególne hasła podawane są w nim wraz z transliteracją dla ułatwienia korzystania z niego tym, którzy nie znają alfabetu dewanagari. Najczęściej autor podaje w zależności od konkretnego słowa jedynie

przypisami, słowniczkiem i posł. opatrzył M. K. Byrski, Warszawa 1988, s. 5-6).

282 Por. M. Monier-Williams, op. cit., s. XXXIII-XXXIV.

28.3 Był m.in. wydany np. w 1924, 1963 i 1974 w Oksfordzie, w 1929 w Londynie, w 1981 na Uniwersytecie Harvarda (w formie cyfrowej w 2009 i 2018). Był i jest nadal wydawany w Indiach, np. w roku 2002, 2004 czy 2006. 
kategorię gramatyczną, rodzaj i kilka wybranych znaczeń. Są też od czasu do czasu krótkie informacje na temat etymologii danego słowa oraz jego derywatów. Jest to słownik często używany w początkowej fazie nauki sanskrytu.

Jak widać, nowożytna europejska tradycja tworzenia i wydawania słowników sanskrytu obejmuje tylko wiek XIX. Powstały w jej ramach przede wszystkim trzy podstawowe słowniki dwujęzyczne, sanskrycko-angielskie autorstwa H. H. Wilsona, M. Moniera-Williamsa oraz A. A. Macdonella oraz jeden słownik sanskrycko-niemiecki, dzieło O. Boehtlingka i R. Rotha. Różniły się one co do swego charakteru. Od słowników bardzo obszernych, uwzględniających ogromną liczbę tekstów oryginalnych i wynikających z ich lektury potencjalnych znaczeń, aż do słownika uproszczonego, którego celem była jak najszybsza lektura tekstów łatwych, używanych w początkowych fazach poznawania sanskrytu. Wszystkie opisane słowniki nie tylko były kluczowymi pracami swojej epoki, ale także są niezbędnymi narzędziami współczesnej pracy indologów $i$ innych badaczy. 


\section{Część VII}

\section{Wybory fragmentów tekstów (chrestomatie)}



W ybory fragmentów tekstów (chrestomatie) jako osobne zbiory były wydawane w ramach nowożytnej europejskiej tradycji tworzenia instrumentów pomocnych w nauce sanskrytu, szczególnie na jej początku, relatywnie rzadko. Za jeden $z$ bardzo ważnych, niejako klasycznych czy tych, które wyznaczyły standard, stając się wzorem dla innych, jest uważany wybór tekstów przygotowany przez Otto Boehtlingka, zatytułowany Sanskrit Chresthomathie.

Warto zatem poświęcić mu choćby parę słów. Został wydany w roku 1845 w Petersburgu ${ }^{284}$. Jest to jednak wybór tekstów przede wszystkim wedyjskich. Między innymi można tu bowiem znaleźć, w dużej obfitości, i hymny z Rigwe$d y$, i z Atharwawedy, i z brahman, a w szczególności z Ajtarejabrahma$n y$ (Aitareyabrāhmaṇa) i z Śatapathabrahmany (Śatapathabrahmāṇa). Jest także m.in. fragment Upaniszady Katha (Kațhopanișad) oraz wyjątek z Aśwalajanagrihjasutry (Āśvalāyanagṛhyasūtra). W dalszej części są teksty teoretyczne dotyczące samej gramatyki oraz fragment indyjskiego słownika



28. Otto Boehtlingk, Sanskrit Chresthomathie, karta tytułowa

284 Jego drugie wydanie ukazało się w roku 1877, trzecie w 1909. Wybór ten jest wznawiany $\boldsymbol{w}$ formie reprintów do tej pory. 
Amarakośi (Amarakośa). Jest także wyimek z tekstu z zakresu poetyki, czyli z Kawjadarśi (Kāvyādarśa). Można, choćby pokrótce, zapoznać się $z$ oryginałem Wedantasar $\gamma$ (Vedāntasarā) Sadanandy (Sadānanda) ${ }^{285}$. Tu fragmenty tekstu opatrzone są uwagami natury gramatycznej. Jest też krótki fragment Ratnawali (Ratnāvalī). Na zakończenie samego wyboru tekstów zapisanych w alfabecie dewanagari autor zamieszcza komentarze gramatyczne, wskazując na niektóre z trudnych form i pokrótce ${ }^{286}$ je objaśniając.

Kolejnym wyborem tekstów, o którym warto wspomnieć tym razem ze względu na jego ogromną popularność w kręgach tak nauczycieli sanskrytu, jak i tych uczących się, jest chrestomatia autorstwa Charlesa Rockwella Lanmana (1850-1941), zatytułowana A Sanskrit Reader, with Vocabulary and Notes.

Autor, mimo że był profesorem na amerykańskim Uniwersytecie Harvarda, za swoich najważniejszych nauczycieli uważa, poza amerykańskim lingwistą i sanskrytologiem Williamem D. Whitneyem, także uczonych europejskich: Albrechta Webera z Uniwersytetu Berlińskiego oraz Rudolpha

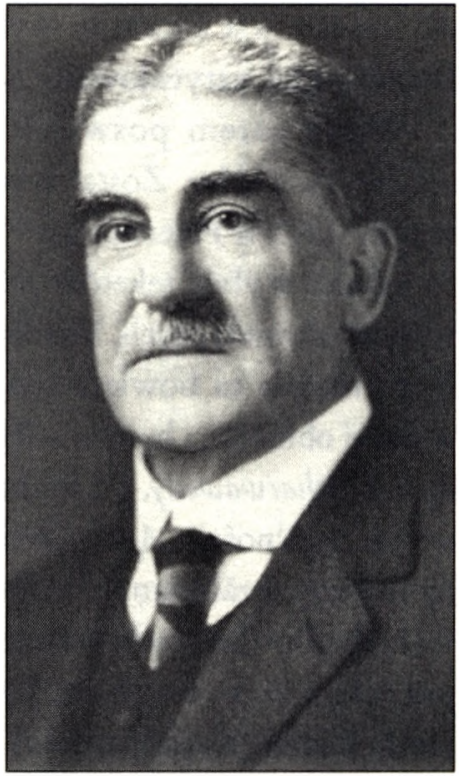

29. Charles Rockwell Lanman

285 Tekstu, który pojawił się w europejskiej tradycji poznawania sanskrytu bardzo wcześnie, bo już w XVII wieku, jako załącznik do gramatyki H. Rotha. ${ }^{280} \mathrm{~W}$ późniejszej tradycji zdarzało się, że wybory fragmentów tekstów podawane były jedynie w transkrypcji (por. K. Mylius, Chrestomathie der Sanskritliteratur, Leipzig 1981). Pytanie o słuszność zastosowania takiej metodologii pozostaje do tej pory otwarte. 
Rotha $z$ uniwersytetu w Tybindze, którym dedykuje swoją pracę. Jego zbiór tekstów można zatem uznać za kontynuację europejskiej tradycji. Dodatkowo to właśnie chrestomatia Lanmana była i jest nadal używana na wielu europejskich uniwersytetach. Lanman opiera się na dostępnych mu krytycznych wydaniach poszczególnych tekstów, każdorazowo wskazując na swoje źródła. Dzieli swoją chrestomatię na trzy części, z których pierwsza stanowi właściwy wybór tekstów. Część druga to słowniczek sanskrycko-angielski, a trzecia - objaśnienia. Teksty sanskryckie wybrane przez Lanmana to w pierwszej kolejności fragmenty pochodzące z Mahabharaty, z Hitopadeśi, z Kathasaritsagary (Kathāsaritsāgara) i Manawadharmaśastry. Dopiero potem Lanman zamieszcza hymny wybrane z Rigwedy, ze zbioru Brahman, w szczególności z Majtrajani (Maitrāyanīsaṃhita), Taittirija (Taittiriyasaṃhita), Ajtareja Brahmany (Aitareyabrahmana) czy z Śatapatha Brahmany. Dalej następują fragmenty pochodzące z Nirukty (Nirukta) oraz z Aśwalajana Grihjasutry (Aśvalayanagṛhyasūtra). Sam słowniczek można nazwać kontekstowym, chociaż jest on o wiele bardziej rozbudowany niż niektóre z tych dołączanych do innych, także współczesnych, czy to wyborów fragmentów tekstów, czy podręczników sanskrytu ${ }^{287}$. Lanman podaje zwykle co najmniej kilka odpowiedników angielskich dla określonych słów sanskryckich, dodając od czasu do czasu także objaśnienia rozmaitej natury, np. mitologicznej ${ }^{288}$. W wielu przypadkach podaje też prawdopodobną etymologię np. rzeczowników oraz, w celach porównawczych, ich podobieństwo do form greckich, łacińskich, angielskich czy niemieckich ${ }^{289}$.

287 Por. słowniczek w podręczniku G. Bühlera lub ten zamieszczony w samouczku M. Coulsona.

288 Por. hasło "agni", w którym nie tylko pisze, że "agni” to ogień bądź święty ogień, ale także bóg Agni, który bywa często pośrednikiem między ludźmi i bogami (Ch. Lanman, $A$ Sanskrit Reader: with Vocabulary and Notes, Boston 1888, s. 111-112).

289 Ibidem, s. $118,121,199 \mathrm{i}$. 
W objaśnieniach Lanman podaje szczegóły natury kulturowej, mitologicznej, geograficznej i historycznej. Opisuje też charakter zamieszczonych w chrestomatii tekstów. Czasem podaje kontekst i streszczenie opowieści, której fragment zamieszcza w swoim wyborze ${ }^{290}$. Komentuje też wybrane formy gramatyczne, pomagając uczącemu się w ich interpretacji. Lanman starał się przygotować swój wybór tekstów w taki sposób, by umożliwić uczącemu się samodzielną pracę z nim, i niewątpliwie to mu się udało. W ciekawy sposób uzasadnia swój wybór fragmentu opowieści o Nalu i Damajanti, który zamieszcza jako pierwszy. Otóż pisze, że znajomość właśnie tego tekstu jest niezwykle przydatna, w wielu bowiem europejskich gramatykach sanskrytu to właśnie cytaty z niego stanowią ilustrację poszczególnych zagadnień gramatycznych ${ }^{291}$. Argument, który przytacza, by uzasadnić wybór fragmentu z Manusmriti, jest także przekonujący. Chce bowiem

SINSKRIT REAIIER:

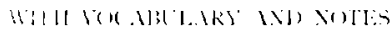

30. Charles Rockwell Lanman, A Sanskrit Reader, with Vocabulary and Notes

290 Tak dzieje się np. w odniesieniu do historii o Nalu i Damajanti, w przypadku której zamieszcza tylko pięć pierwszych rozdziałów (sarga).

291 Tak zresztą jest również w przypadku popularnego słownika autorstwa M. Moniera-Williamsa. 
zwrócić uwagę uczących się na ważność tego tekstu dla całej kultury indyjskiej ${ }^{292}$. Swój słowniczek opiera głównie na słowniku Sanskrit-Woerterbuch Boehtlingka i Rotha ${ }^{293}$. Chrestomatia Lanmana często była polecana jako uzupełnienie wydanej w roku 1875 gramatyki Williama Dwighta Whitneya ${ }^{294}$ zatytułowanej Sanskrit Grammar. Including both the Classical language, and the Older Dialects, of Veda and Brahmana ${ }^{295}$. Jako że Lanman w swojej chrestomatii wskazuje jednoznacznie na to, iż jego wybór tekstów należy studiować wraz z gramatyką Whitneya, warto dodać kilka słów dotyczących jej, by w kontekście wydawanych w przeszłości i obecnie takich właśnie pomocy dla uczących się pokazać, jak chrestomatie mogą być używane równolegle z lekturą samych gramatyk. Otóż gramatyka Whitneya była pracą wpisującą się w nurt gramatyk historyczno-porównawczych. Mimo że Whitney był Amerykaninem, także i jego gramatykę można włączyć w nurt gramatyk europejskich. Na niektórych z nich bowiem z pewnością ją wzorował. Whitney oceniał dotychczas istniejące europejskie gramatyki jako niewystarczające do dobrego poznania gramatyki sanskrytu. Jednocześnie sam przyznawał, że korzystał $z$ wielu prac autorów europejskich gramatyk. Wymienia

292 Ch. Lanman, op. cit., s. IV.

293 Ibidem, s. VI.

294 Tak zresztą poleca ją sam autor, pisząc we wstępie, co następuje: „The Reader is made as a companion - volume to Whitney's Sanskrit Grammar [...]" ("Ten wybór tekstów zalecany jest jako uzupełnienie Sanskrit Grammar autorstwa Ch. Whitneya"; Ch. La n ma n, op. cit., s. III). We wstępie do swego wyboru tekstów pisze też, że to właśnie do gramatyki Whitneya podaje referencje, objaśniając skrótowo poszczególne formy gramatyczne (por. ibidem, s. VI).

295 Gramatyka ta była i jest nadal powszechnie znana. W roku 1885 , jako uzupełnienie tej gramatyki, Whitney wydał prace Roots, Verb Forms and Primary Derivatives of the Sanskrit Language, również używaną, z korzyścią dla uczących się, do tej pory. Drugie wydanie samej gramatyki ukazało się w roku 1889 równolegle w Cambridge i w Londynie. 
między innymi gramatyki Kielhorna, M. Moniera-Williamsa, F. Boppa, T. Benfeya czy M. Müllera. Dodaje, iż nieocenioną pomocą był dla niego także słownik autorstwa O. Boehtlingka i R. Rotha. Źródłem wiedzy była dla niego także wydana w latach pomiędzy pierwszą i drugą wersją jego własnej gramatyki praca A. Holtzmanna zawierająca zbiór fragmentów Mahabharaty oraz zbiór fragmentów tekstów tym razem pochodzących z Ramajany, przygotowany przez O. Boehtlingka ${ }^{296}$. Jego założeniem było stworzenie gramatyki historyczno-porównawczej, w której poszczególne formy sanskrytu klasycznego podawał w ich zestawieniu z formami wedyjskimi. Sama gramatyka składa się z 18 rozdziałów, do których dołączony jest apendyks, w którym autor gromadzi przykłady różnych typów możliwego zapisu tekstów czy inaczej: warianty alfabetu dewanagari wraz $z$ transkrypcją. Te krótkie teksty wybrane są zarówno z sanskrytu, jak i z literatury wedyjskiej. Całość zaopatrzona jest $\mathbf{w}$ indeksy dotyczące określonych form gramatycznych i odsyłające do poszczególnych paragrafów w gramatyce. W samej gramatyce opisano zagadnienia gramatyczne w klasycznej kolejności, przez fonetykę, kategorię nomen, kategorię verbum, derywację, formy nieodmienne aż do złożeń. W podawanych przykładach Whitney używa, podobnie jak wielu innych twórców gramatyk sanskrytu, form zapisanych w alfabecie dewanagari. Często jednak przykłady podaje w transkrypcji. Wielokrotnie $w$ treści swej gramatyki podaje poza formami sanskryckimi, np. tymi, które można odnaleźć w eposach, Mahabharacie czy Ramajanie, również wedyjskie, przede wszystkim pochodzące z Rigwedy i Atharwawedy. Zamieszcza też dużą liczbę paradygmatów odmian. Często wtedy, w formach komentarzy, dodaje analogiczne odmiany form wedyjskich ${ }^{297}$.

296 Wydana w roku 1884 jako suplement do jego własnej gramatyki.

297 Same paradygmaty - można stwierdzić, że niekonsekwentnie - podaje czasem $\mathbf{w}$ alfabecie dewanagari, czasem $\mathbf{w}$ transkrypcji, a czasem $\mathbf{w}$ dewa- 
W nowożytnej europejskiej tradycji powstawały jeszcze inne wybory tekstów. Można wspomnieć o tym wydanym bardzo wcześnie, bo w roku 1820 bądź 1821 w Monachium, czyli o chrestomatii autorstwa Othmara Franka zatytułowanej Chrestomathia Sanscrita quam ex codicibus manuscriptis, adhuc ineditis Londini exscriptis atque in usum tironum versione, expositione, tabulis grammaticis etc., illustratam edidit. Można też wymienić bardzo wczesną pracę Williama Yatesa The Sunscrit Reader, or easy introduction to the Reading of the Sunscrit language, która ukazała się w roku 1822 w Kalkucie. Chrestomatię Boehtlingka poprzedziła też ta autorstwa Christiana Lassena o tytule Anthologia Sanscritica glossario instructa, wydana w Bonn w roku 1838. Nie jest pewne, czy w przypadkach, gdy tego nie wzmiankują, autorzy wyborów tekstów wiedzieli o ukazujących się często prawie równolegle innych chrestomatiach, które powstawały w tak różnych miejscach. Być może to było jednym z powodów, dla których powtarzały się one w niektórych $\mathrm{z}$ wyborów tekstów.

Te opisane wyżej pokrótce wybory tekstów mające służyć pomocą w nauce sanskrytu stanowią niewielką część, ale za to charakterystycznych przykładów. Należy jednak stwierdzić, iż wybory tekstów, które miałyby charakter oddzielnych prac, powstawały i nadal powstają w relatywnie małej liczbie. Współczesna tendencja to raczej dodawanie ich do samych gramatyk bądź opieranie koncepcji gramatyk na wybranych tekstach literackich ${ }^{298}$.

nagari i transkrypcji zarazem. To warte komentarza, gdyż dla uczącego się lepiej byłoby zachować tu spójność.

${ }^{298}$ Por. Devavānipraveśikā. An introduction to the Sanskrit language autorstwa Roberta P. Goldmana i Sally J. Sutherland; autorzy oparli ten podręcznik stopniowej nauki na tekście eposu Ramajana. 



\section{Zakończenie}

istoria nowożytnych europejskich starań podejmowanych w celu jak najbardziej precyzyjnego opisu gramatyki sanskrytu liczy sobie prawie 400 lat. By dokonać tego dzieła, wielu autorów, korzystając z dostępnych im źródeł, próbowało przybliżać ten często prawie całkowicie nieznany temat publiczności europejskiej. Opracowania, mniej lub bardziej precyzyjne, pojawiały się na tyle często, że można podjąć próbę ustalenia na podstawie analizy ich treści i metod stosowanych przez autorów odpowiedzi na pytanie, czy da się wyróżnić charakterystyczne dla europejskiej tradycji trendy w opisach.

Gramatyk na przestrzeni od XVII do XIX wieku - czyli w okresie, którego dotyczy ta książka - powstało, licząc wraz z pracami, które do tej pory pozostają w formie manuskryptów, około 70. Tutaj analizowano przede wszystkim te zapisy wane po łacinie, w języku angielskim bądź niemieckim, jako że to właśnie one wyznaczały występujące w Europie trendy. Powstające wtedy, choć w bardzo małej liczbie, gramatyki w innych europejskich językach były bądź tłumaczeniami, bądź nieznacząco różniącymi się wersjami tych ostatnich. Wspomina się o nich zatem jedynie marginalnie. Jedyny wyjątek uczyniony został dla tradycji polskiej, ponieważ niniejsze opracowanie skierowane jest, ze względu na język, w którym zostało napisane, przede wszystkim do polskiego czytelnika.

Europejczycy opisujący sanskryt, w zależności od źródeł, na których się opierali, podążali w swych wykładach albo za znaną im indyjską tradycją gramatyczną, albo za istniejącą już tradycją europejską. Miało to wpływ np. na terminologię gramatyczną, której używali, 
charakteryzując poszczególne zagadnienia gramatyczne. Była to bądź terminologia sanskrycka, bądź łacińska, bądź stosowna dla odpowiedniego języka europejskiego, w którym gramatyka była napisana (np. angielska, niemiecka czy polska). Oczywiście wybór tej czy innej metody opisu wpływał na mniejszą lub większą jej adekwatność. Ten ostatni problem nie znalazł zresztą jednolitego rozwiązania do tej pory. Poszczególni autorzy gramatyk powstających współcześnie wybierają własne drogi rozwiązywania go, często nie uzasadniając swego wyboru.

Z treści książki wynika, że jest możliwa próba ustalenia, jakie nurty pojawiały się w opisach gramatyki sanskrytu w perspektywie diachronicznej. Wieki XVII i XVIII to czas, kiedy gramatyki były pisane przez europejskich misjonarzy. Tu przede wszystkim należy wymienić gramatyki stworzone przez Ernsta Johanna Hanxledena, Heinricha Rotha czy Paulinusa a Sancto Bartholomaeo. Faza kolejna to początki XIX wieku, kiedy przede wszystkim mamy do czynienia z efektami prac badaczy takich jak Charles Wilkins, Henry Thomas Colebrooke czy Horace Hayman Wilson. Wszyscy oni w ten czy inny sposób związani byli z działalnością Kompanii Wschodnioindyjskiej. W tym czasie dominowały gramatyki o charakterze opisowym. Były to gramatyki, których autorzy, dzięki pomocy lokalnych informatorów, znawców indyjskiej tradycji gramatycznej, opierali się w swoich opracowaniach przede wszystkim na źródłach indyjskich. Różniły się one jednak wieloma szczegółami, tak zawartością, jak i metodami przedstawiania materiału gramatycznego. Wydaje się bardzo prawdopodobne, iż autorzy często nie wiedzieli o gramatykach pisanych wtedy przez innych Europejczyków, i w tym sensie były to ich starania indywidualne.

Początek XIX wieku to z kolei okres, w którym pojawiły się gramatyki pisane przez osoby znające sanskryt przede wszystkim z gramatyk napisanych przez innych europejskich autorów. Sami oni nie zdobywali 
wiedzy o sanskrycie w Indiach, często zresztą nigdy osobiście Indii nie odwiedzili. Za sprawą wybitnego niemieckiego językoznawcy Franza Boppa pojawił się nowy trend w opisach sanskrytu, który został określony jako gramatyki porównawcze. Z czasem zaczęły także powstawać gramatyki o charakterze historyczno-porównawczym. Te ostatnie jednak to raczej wiek XX niż XIX.

Wreszcie charakterystyczną cechą końca XIX wieku jest to, iż gramatyki tworzone przez autorów takich jak np. Georg Bühler przełamywały tradycję gramatyk opisowych, pokazując, że jedną z możliwych dróg poznawania sanskrytu jest także nauka dokonywana drogą dydaktyczną, w ramach której materiał gramatyczny dzielony jest na lekcje, w których zagadnienia gramatyczne omawiane są nie w formie przeglądowej, ale stopniowo. Były to zatem opracowania nazywane podręcznikami.

Przełom XIX i XX wieku przyniósł jedną z pierwszych prób przedstawienia gramatyki sanskrytu $w$ formie uproszczonej, pozbawionej nadmiernej ilości informacji dotyczących np. form nietypowych. Taką właśnie gramatyką, której autor użył świadomie tej metody, była gramatyka Arthura A. Macdonella.

Przedstawiając tradycję europejskich gramatyk sanskrytu w perspektywie synchronicznej, należy stwierdzić, że w ciągu omawianych prawie 400 lat tradycji za najbardziej typowe należy uznać gramatyki opisowe. Materiał gramatyczny jest w nich przedstawiany $\mathbf{w}$ formie książek, których zawartość dzielona jest na części, rozdziały i podrozdziały, w ramach których po kolei omawiane są poszczególne zagadnienia gramatyczne. Kolejność prezentacji tych zagadnień powtarza się w ogromnej liczbie gramatyk. Opis rozpoczyna się zwykle od informacji na temat fonetyki, by przez opis kategorii nomen ( $\mathrm{z}$ rozmaitą w różnych pracach szczegółowością) przejść do kategorii verbum. Jako osobną część gramatyki te posiadają rozdziały poświęcone złożeniom, wielu bowiem autorów ten właśnie temat uważało 
za niezmiernie ważny dla pełnego poznania sanskrytu. Wiadomości o składni często stanowią ostatnią część opracowań. Również opisowe, ale takie, których cel jest odmienny od gramatyk omówionych powyżej, są gramatyki o charakterze porównawczym. To nie informacje o samej tylko gramatyce sanskrytu są tu istotne. Równie ważne, bądź nawet ważniejsze, jest pokazanie sanskrytu $w$ zestawieniu $z$ innymi językami - przede wszystkim indoeuropejskimi. Kolejnym rodzajem, który niewątpliwie można wyróżnić w ramach europejskiej tradycji, są gramatyki typu pedagogicznego, te, których głównym zadaniem jest nie sam opis poszczególnych zagadnień, ale także sprawienie, by materiał ten był łatwy w przyswojeniu go sobie w ramach stopniowej nauki, czy to samodzielnej, czy z nauczycielem. Te opracowania poza przedstawieniem materiału gramatycznego posiadają też zestawy ćwiczeń pomocnych w utrwalaniu znajomości poszczególnych zagadnień.

Na zakończenie należy stwierdzić, że gramatyki powstałe w wiekach XVII-XIX to takie, które dobrze mogą służyć, i do tej pory zresztą służą, biernej znajomości sanskrytu. Umożliwia ona lekturę tekstów oryginalnych. Również współcześnie dla wielu jest to najważniejszy powód opanowywania reguł gramatyki sanskrytu. Za nieistotne, czy w każdym razie niebędące głównym celem, uważano tak wtedy, jak i teraz posiadanie czynnej znajomości tego języka. Ten trend pojawił się w zasadzie dopiero w wieku XX.

Na pytanie o zakładany przez autorów gramatyk krąg potencjalnych odbiorców nie można udzielić jednoznacznej odpowiedzi. Byli to bowiem i są niewątpliwie ci, którym znajomość sanskrytu mogła w ten czy inny sposób przydać się do realizacji celów, które od teoretycznych mogły prowadzić także do tych praktycznych. Poczynając od czystej ciekawości, przez chęć używania znajomości indyjskich nie tylko świętych tekstów sanskryckich w celu chrystianizacji ludności lokalnej aż do ustalania prawodawstwa mającego pomóc w panowaniu nad Indiami czasów kolonialnych. Europejscy czytelnicy opisów 
gramatyki sanskrytu składali się tak z przedstawicieli zakonów, jak i z urzędników i intelektualistów czy poetów i pisarzy oraz naukowców, w szczególności tych o zainteresowaniach językowych. Obecnie lektura i analiza tekstów gramatyk służy także badającym historię nauki i relacji indyjsko-europejskich, czego najlepszym dowodem jest właśnie ta książka. 

Appendyksy 

Gramatyki sanskrytu - alfabetycznie

Ballantyne, James Robert, $A$ catechism of Sanskrit grammar, London-Edinburgh 1843 (wyd. 3 London 1850 lub 1851).

Ballantyne, James Robert, First lessons in Sanskrit grammar, with an introduction to the Hitopadesa, Mirzapore 1850 lub 1851 (wyd. 2 1862; wyd. 3 London 1865; wyd. 4 London 1885, reprint Point Loma 1941).

Baudry, Frédéric, Grammaire sanscrite. Résumé élémentaire de la théorie des formes grammaticales du Sanscrit, Paris 1852.

Benfey, Theodor, Handbuch der Sanskritsprache. Zum Gebrauch für Vorlesungen und zum Selbsstudium von Theodor Benfey, Leipzig: F. A. Brockhaus 1852-1854.

Benfey, Theodor, Kurze Sanskrit-Grammatik zum Gebrauch für Anfänger, Leipzig 1855.

Bergaigne, Abel Henri Joseph, Manuel pour étudier la langue sanscrite. Chrestomathie - Lexique - Principes de grammaire, Paris: F. Vieweg 1884 (reprint Genève 1984).

Boller, Anton, Ausführliche Sanskrit-Grammatik für den öffentlichen und Selbstunterricht, Wien 1847.

Boltz, August, Vorschule des Sanskrit in lateinischer Umschrift, Oppenheim 1868.

Bopp, Franz, Ueber das Konjugationssystem der Sanskritsprache in Vergleichung mit jenem der griechischen, lateinischen, persischen und germanischen Sprache, (Nebst Episoden des Ramayan und Mahabharat in genauen metrischen Uebersetzungen aus dem Originaltext und einigen Abschnitten aus den Vedas Herausgegeben und mit einer Vorerinnerung begleitet von K.J. Windischmann, Frankfurt am Main 1816.

Bopp, Franz, Ausführliches Lehrgebäude der Sanskrita-Sprache, Berlin (1 facs. 1824) 1827; wyd. 2 Grammatica critica linguae sanscritae, Berlin 1832.

Bopp, Franz, Vergleichende Grammatik des sanskrit, send, griechischen, lateinischen, lituanischen, altslavischen, gothischen und deutschen, Berlin: Dümmler 1833-1852. 
Bopp, Franz, Kritische Grammatik der Sanskrita-Sprache in kürzerer Fassung, Berlin (1832) 1834 (wyd. 2 poprawione Berlin: Nicolaischen Buchhandlung 1845; wyd. 3 1863; wyd. 4 zredagowane przez E. Siecke Berlin: Nicolaischen Buchhandlung 1868).

Brown, Thomas Richard, The essentials of Sanskrit grammar, with examples of parsing, Southwick: Brown 1841.

Burnouf, Émile-Louis, L. Leupol (pseudonim François-Étienne Leloup de Cheray), Méthode pour étudier la langue sanskrite, Nancy 1859 (wyd. 2 Paris 1861).

Burrit, Elihu, Social walks and talks with young students among the languages; a Sanskrit handbook for the fireside, London 1875.

Bühler, Georg, Third book of Sanscrit, 1877; 1888.

Bühler, Georg, Leitfaden für den Elementarcursus des Sanskrit: Mit Übungsstücken und Zwei Glossaren von Georg Bühler, Wien: Verlag von Carl Konegen 1883 (wyd. 2 poprawione przez J. Nobel, Wien 1927; thum. polskie Bolesław Baranowski, red. Eugeniusz Stuszkiewicz, Podręcznik sanskrytu, Warszawa 1977).

Carey, William, A Grammar of the Sungskrit language, composed from the works of the most esteemed Grammarians, to which are added examples for the exercises of the student, and a complete list of dhatoos, or roots, Serampore: Mission Press (1804) 1806.

Colebrooke, Henry Thomas, $A$ Grammar of the Sanscrit Language, vol. 1, Calcutta: The Honorable Company's Press 1805.

Colinet, Philémon, La langue et la littérature sanscrites, deux leccons d'introduction au cours de sanscrit, Gand 1888.

Desgranges, M., Grammaire sanscrite-française, 2 tomy, Paris 1845-1847. Edgren, August Hjalmar, Sanskritsprakets formlaara jaamte kort oofversigt af prakritdialekten samt inledande laasoofnigar, Lund 1883.

Edgren, August Hjalmar, Jamforande grammatik, omfattande Sanskrit, Grekiska, Latin och Gotiska, Gootenburg 1893.

Ferrar, William Hugh, A Comparative Grammar of Sanskrit, Greek and Latin, 1869.

Fick, Richard, Praktische Grammatik der Sanskrit-Sprache für den Selbstunterricht. Mit Uebungsbeispielen, Lesestücken und Glossaren, Wien, Pest, Leipzig: A. Hartleben's Verlag 1891 (wyd. 3 Wien-Leipzig 1922; reprint Wiesbaden: Steiner 1983).

Flecchia, Giovanni, Grammatica Sanscrita, Torino: Marietti 1856.

Forster, Henry Pitts, Sanskrit Grammar, 1804. 
Forster, Henry Pitts, An Essay on the Principles of Sanskrit Grammar, part 1, Calcutta 1810.

Frank, Othmar, Vyākaraṇaṃ śästracakșus. Grammatica sanscrita, nunc primum in Germania edidit, Wirceburgi 1823.

Fumi, Fausto Gherardo, Limen indicum. Avviamento allo studio del sanscrito, litographed, Palermo 1887 [wyd. 2 Milano 1891 (251 s.); wyd. 3 poprawione Milano 1905].

Geiger, Wilhelm, Elementarbuch der Sanskritsprache. Grammatik, Lesestücke und Glossar, München 1888 (wyd. 2 poprawione i rozszerzone Elementarbuch des Sanskrit, unter Berücksichtigung der vedischen Sprache, 3 vols., Strassburg 1909; wyd. 3, z dodatkiem, Berlin-Leipzig 1923).

Gelabert y Gordiola, Juan, Manual de lengua sanskrita. Crestomatía y gramática, Madrid 1890.

Giusanni, Carlo, Principii della grammatica Sanscrita. Aggiunti due brani di testo, per esercizio di lettura e traduzione, Torino e Firenze: Loescher 1868 (wydane także jako appendix do Angelo de Guernatis, Piccola Enciclopedia Indiana).

Grammatica Grandonica: The Sanskrit Grammar of Johann Ernst Hanxleden S.J. (1681-1732), introduced by Toon Van Hal, Christophe Vielle, with a photographical reproduction of the original manuscript by Jean-Claude Muller, Potsdam 2013.

Hanxleden, Ernst Johann, Grammatica Grandonica, napisana pomiędzy 1712-1732.

Hatfield, James Taft, Elements of Sanskrit Grammar, 1884.

Holtzmann, Adolf, Grammatisches aus dem Mahäbhärata, ein anhang zu William Dwight Whitney's indischer Grammatik, Leipzig 1884.

Kellner, Hermann Camillo, Sävitri. Praktisches Elementarbuch zur Einführung in die Sanskritsprache, ein buch zum Selbstunterrichte für Philologen und gebildets Laien, Leipzig 1888.

Kielhorn, Franz, A Grammar of the Sanskrit Language, Bombay 1870 (wyd. 5 Bombay: Nirnaya Sagar Press 1912; wyd. 6 Varanasi: The Chowkhamba Sanskrit Series Office 1970).

Kielhorn, Franz, Grammatik der Sanskrit-Sprache. Aus dem Engl. Übersetzt von W. Solf, Berlin 1888.

Lebedev, Gerasim, A grammar of the pure and mixed East Indian dialects, with dialogues affixed and arranged according to the Brahmanian system of the Shamscrit language with a recitation of the assertions of Sir William Jones, respecting the Shamscrit alphabet, London 1801. 
Macdonell, Arthur Anthony, Sanskrit Grammar for Beginners, London 1901 (wyd. 2 Oxford 1911; wyd. 3, zatytułowane $A$ Sanskrit Grammar for Students, Oxford 1927; reprinty ind. 1974, 1979, Delhi: Motilal Banarsidass).

Malinowski, Franciszek, Prospekt na gramatykę sanskrytu porównanego z językiem starosłowiańskim i polskim na podstawie sanskryckiej gramatyki Franciszka Boppa, Komorniki pod Poznaniem 1871.

Malinowski, Franciszek, Gramatyka sanskrytu porównanego z językiem starosłowiańskim i polskim. Na podstawie sanskryckiej gramatyki Franciszka Boppa napisana przez Ks. Franc. Xaw. Malinowskiego, plebana z Komornik pod Poznaniem, członka Poznańskiego Towarzystwa Przyjaciół Nauk, Poznań: Drukarnia T. H. Daszkiewicza (staraniem Ludwika Rzepeckiego) 1872.

Miller, V. F., Knauer, F. I., Rukovodstvo k izucceniju sanskrita. Grammatika, teksty, slovar, Sankt Petersburg 1891.

Monier-Williams, Monier, An elementary grammar of the Sanskrit language, partly in the Roman character, arranged according to a new theory, in reference especially to the Classical languages, with short extracts in easy prose, to which is added a selection from the Institutes of Manu, with copious references to the grammar, and an English translation by Monier Williams, London 1846 (wyd. 4 1876).

Monier-Williams, Monier, $A$ Practical grammar of the Sanskrit language, arranged with reference to the Classical languages of Europe, for the use of English students, London: The Clarendon Press 1857 [wyd. 2 Oxford 1857; wyd. 4 Oxford 1876; wyd. ind. Varanasi: Chowkhamba Sanskrit Series Office (Chowkhamba Sanskrit Studies, vol. 21) 1962; reprint New Delhi: Oriental Books Reprint Corporation 1978].

Müller, Max Friedrich, $A$ Sanskrit Grammar for Beginners in Devanägari and Roman Letters Throughout, London 1866 (wyd. 2 poprawione London 1870).

Müller, Max Friedrich, $A$ Sanskrit Grammar for Beginners (new and abridged edition accented and transliterated throughout with a chapter on syntax and an appendix on classical metres by Arthur Anthony Macdonell), London 1886.

Müller, Max Friedrich, Max Müller's Sanskrit-Grammatik in Devanagari und lateinischen Buchstaben. Aus dem Englischen übersetzt von F. Kielhorn und G. Oppert.

Nazari, Oreste, Elementi di grammatica sanscritica. Seguiti da esercizi graduali, antologia e lessico con caratteri Devanägarī, 1892 (Torino 1948). 
Oppert, Jules, Grammaire sanscrite, Berlin-Paris 1857 (wyd. 2 poprawione Berlin 1864).

Paulinus a Sancto Bartholomaeo, Sidharubam seu Grammatica Samscridamica. Cui accedit Dissertatio historico-critica in linguam Samscridamicam, vulgo Samscret dictam in qua huius linguae existentia, origo, praestantia, antiquitas, extensio, maternitas ostenditur, libri aliqui ex ea exarati critice recensentur, et simul aliquae antiquissimae gentilium orationes liturgicae paucis attinguntur, et explicantur, Romae: S.C. de Propaganda Fide 1790.

Paulinus a Sancto Bartholomaeo, Vyacarana seu locupletissima Samscrdamicae linguae institutio, in usum fidei praeconum in India orientali, et per virorum litteratorum in Europa adornata, Romae: S.C. de Propaganda Fide 1804. Perry, Edward Delavan, A Sanskrit Primer, oparte na Leitfaden für den Elementarcursus des Sanskrit [napisanym przez Georga Bühlera, Boston: Ginn 1885 (wyd. 2 1886; reprint 1892, 1895; wyd. 3 1901; reprint 1903, 1904, 1907, 1911, 1915, 1919, 1923, 1927, 1929; wyd. 4 1936; reprint 1943, 1946, 1950, 1953, A Sanskrit primer, New York-London: Columbia University Press; wyd. ind. Delhi 1936, reprint Delhi: Motilal Banarsidass 1978, 1982, 1986, 1988, 1992, 1994, 1997, 1999]. Petrov, P., Sanskritskaja gramatika. 1. Devanagarskij alfavit i ctenie, Moskva 1865.

Pizzi, Italo, Grammatica elementare della lingua sanscrita con temi antologia e vocabulario, Torino: Clausen 1896.

Pons, Jean Francois, Codex chartaceus quo continentur Grammatica et dictionarium linguae samscretanicae, rps niepublikowany.

Pons, Jean Francois, Rudiments de la langue samskretane en latin, rps niepublikowany.

Price, William, Elements of the Sanscrit language, or an easy guide to the Indian tongues, London 1828.

Pullè, Francesco Lorenzo, Grammatica sanscrita, Torino: Loescher 1883. Rivero, Francisco Maria D., Grammatica elemental del Sanscrito clasico, Madrid 1881.

Rodet, Leon, Grammaire abrégée de la langue sanscrite, 2 vols., Paris 18591860.

Roth, Heinrich, Grammatica linguae Sanscretanae Brachmanum Indiae Orientalis, 1660-1662.

Scherzl, V. I., Sanskritskaja grammatika, vol. 1, Harkov 1873.

Schultze, B., Grammatica Granthamica seu Samscridamica, rps niepublikowany. 
Skorochód-Majewski, Walenty, Rozprawy o jezzku sanskryckim, tudzież o literaturze Indyan w tymże jezyku, z przydatkiem wyciagu gramatyki tegoż języka, Warszawa 1816.

Skorochód-Majewski, Walenty, Gramatyka mowy starożytnych Skuthów, czyli Skalnych Gorali, Indo-Skythów, Indyków, Budhynów, Herodota samskrytem, czyli dokładnq mowq zwaney. $Z$ oryginału samskrytskiego przekładu pp. Colebrooke, Carey, Wilkins, Yates, Forster $i$ innych, a szczególniey podług poprawniejszego wydania prof. Bopp w Berlinie, dotąd jeszcze nie ukończonego przez Walentego Skorochod Maiewskiego czlonka Izby Poselskiey, do dyjalektu polskiego $i$ innych słowianskich zastosowana $i$ ulepszona. $Z$ przypisami $z$ całego dzieła zebranymi, naukę pisania, $c z y-$ tania, wymawiania $i$ zrozumienia obeymuiacymi $i$ z siedemnasto tablicami, odmiany pisania i rytowania głosek, ięzyków wschodnich, odmiany części mowy, wyciagi z różnych dziet przedstawiajqcemi, Warszawa 1828.

Stenzler, Adolf Friedrich, Elementarbuch der Sanskrit-Sprache. Grammatik, Texte, Woerterbuch, Breslau: M. Mälzer 1868 (1869) (wyd. 2 Breslau 1872; wyd. 3 1875; wyd. 4 Breslau 1880; wyd. 5 1885; wyd. 6 poprawione przez Richarda Pischela, Breslau: Louis Koehler's Hofbuchhandlung 1892; wyd. 7 1902; wyd. 8 1908; wyd. 9 poprawione przez Karla Friedricha Geldnera 1915; wyd. 10 1923; wyd. 11 1939; wyd. 12 1943; wyd. 13 1952; wyd. 14 poprawione i uzupetnione przez Samarendranatha Biswasa; wyd. 15 1965; wyd. 16 1970; wyd. 17 1980; wyd. 18 poprawione przez Albrechta Wetzlera Berlin-New York: Walter de Gruyter 1995).

Vasconcellos-Abreu, Guilherme, de, Principios elementares da grammatica da lingua sãoskrita, Lisboa 1879.

Vasconcellos-Abreu, Guilherme, de, Manual para o estudo do saoskrito classico, Lisboa 1881.

Westergaard, Niels Ludwig, Sanskrit laesebog med tilhörende ordsamling, Kjöbenhavn 1846.

Whitney, William Dwight, A Sanskrit Grammar, including both the Classical language, and the older dialects of Veda and Brahmana, Leipzig: Breitkopf \& Härtel 1879 (wyd. 2 poprawione i rozszerzone 1889; wyd. 3 London 1896; wyd. 81955 London: Oxford University Press; reprint 1964 Cambridge, MA: Harvard University Press; 1980; wyd. 8 1995; ind. reprint 1962, 1969 Delhi: Motilal Banarsidas). 
Whitney, William Dwight, Indische Grammatik. Umfassend die Klassische Sprache und die älteren Dialecte. Aus dem Englischen übersetzt von Heinrich Zimmer, Leipzig 1879; Hildesheim-New York-Wiesbaden 1980. Wilkins, Charles, A Grammar of the Sanskrita language, London (1795) 1808. Wilson, Horace Hayman, An introduction to the Grammar of the Sanskrit Language for the use of early Students, London 1841 (wyd. 2 London: J. Madden and Co. 1847); wyd. ind. Varanasi 1961).

Woollaston, M. W., A practical grammar of the Sanskrit language, part 1, Calcutta: Serampore Press 1835.

Yates, William, $A$ Grammar of the Sunscrit language, on a new plan, Calcutta 1820 (wyd. 2 poprawione i rozszerzone $A$ Grammar of the Sanskrit language on a plan similar to that most commonly adopted in the learned languages of the West, Calcutta: Baptist Mission Press 1845).

\section{Gramatyki sanskrytu - chronologicznie}

Roth, Heinrich, Grammatica linguae Sanscretanae Brachmanum Indiae Orientalis, 1660-1662.

Hanxleden, Ernst Johann, Grammatica Grandonica: The Sanskrit Grammar of Johann Ernst Hanxleden S.J. (1681-1732), introduced by Toon Van Hal, Christophe Vielle, with a photographical reproduction of the original manuscript by Jean-Claude Muller, Potsdam 2013; napisana pomiędzy 1712-1732.

Paulinus a Sancto Bartholomaeo (Filip Vesdin, Filip Vezdin), Sidharubam seu Grammatica Samscridamica. Cui accedit Dissertatio historico-critica in linguam Samscridamicam, vulgo Samscret dictam in qua huius linguae existentia, origo, praestantia, antiquitas, extensio, maternitas ostenditur, libri aliqui ex ea exarati critice recensentur, et simul aliquae antiquissimae gentilium orationes liturgicae paucis attinguntur, et explicantur, Romae: S.C. de Propaganda Fide 1790.

Wilkins, Charles, $A$ Grammar of the Sanskrita language, London (1795) 1808. Lebedev, Gerasim, $A$ grammar of the pure and mixed East Indian dialects, with dialogues affixed and arranged according to the Brahmanian system of the Shamscrit language with a recitation of the assertions of Sir William Jones, respecting the Shamscrit alphabet, London 1801.

Carey, William, A Grammar of the Sungskrit language, composed from the works of the most esteemed Grammarians, to which are added examples for 
the exercises of the student, and a complete list of dhatoos, or roots, Serampore: Mission Press (1804) 1806.

Forster, Henry Pitts, Sanskrit Grammar, 1804.

Paulinus a Sancto Bartholomaeo, Vyacarana seu locupletissima Samscrdamicae linguae institutio, in usum fidei praeconum in India orientali, et per virorum litteratorum in Europa adornata, Romae: S.C. de Propaganda Fide 1804. Colebrooke, Henry Thomas, $A$ Grammar of the Sanscrit Language, vol. 1, Calcutta: The Honorable Company's Press 1805.

Forster, Henry Pitts, An Essay on the Principles of Sanskrit Grammar, part 1, Calcutta 1810.

Bopp, Franz, Ueber das Konjugationssystem der Sanskritsprache in Vergleichung mit jenem der griechischen, lateinischen, persischen und germanischen Sprache, (Nebst Episoden des Ramayan und Mahabharat in genauen metrischen Uebersetzungen aus dem Originaltext und einigen Abschnitten aus den Vedas Herausgegeben und mit einer Vorerinnerung begleitet von K.J. Windischmann, Frankfurt am Main 1816.

Skorochód-Majewski, Walenty, Rozprawy o języku sanskryckim, tudzież o literaturze Indyan w tymże jezzku, z przydatkiem wyciqgu gramatyki tegoż jezzka, Warszawa 1816.

Yates, William, $A$ Grammar of the Sunscrit language, on a new plan, Calcutta 1820 (wyd. 2 poprawione i rozszerzone $A$ Grammar of the Sanskrit language on a plan similar to that most commonly adopted in the learned languages of the West, Calcutta: Baptist Mission Press 1845).

Frank, Othmar, Vyäkaranam śăstracakșus. Grammatica sanscrita, nunc primum in Germania edidit, Wirceburgi 1823.

Bopp, Franz, Ausführliches Lehrgebäude der Sanskrita-Sprache, Berlin (1 facs. 1824), 1827; wyd. 2 po łacinie jako Grammatica critica linguae sanscritae, Berlin 1832.

Price, William, Elements of the Sanscrit language, or an easy guide to the Indian tongues, London 1828.

Skorochód-Majewski, Walenty, Gramatyka mowy starożytnych Skuthów, czyli Skalnych Gorali, Indo-Skythów, Indyków, Budhynów, Herodota samskrytem, czyli dokładnq mowq zwaney. $Z$ oryginału samskrytskiego przektadu pp. Colebrooke, Carey, Wilkins, Yates, Forster $i$ innych, a szczególniey podług poprawniejszego wydania prof. Bopp w Berlinie, dotąd jeszcze nie ukończonego przez Walentego Skorochod Maiewskiego członka Izby Poselskiey, do dyjalektu polskiego $i$ innych stowianskich zastosowana $i$ ulepszona. $Z$ przypisami $z$ calego dzieła zebranymi, naukę pisania, czy- 
tania, wymawiania i zrozumienia obeymuiącymi $i$ z siedemnasto tablicami, odmiany pisania i rytowania głosek, iqzyków wschodnich, odmiany częsici mowy, wyciagi z różnych dziet przedstawiajacemi, Warszawa 1828.

Bopp, Franz, Kritische Grammatik der Sanskrita-Sprache in kürzerer Fassung, Berlin (1832) 1834 (wyd. 2 poprawione Berlin: Nicolaischen Buchhandlung 1845; wyd. 3 1863; wyd. 4 zredagowane przez E. Siecke Berlin: Nicolaischen Buchhandlung 1868).

Bopp, Franz, Vergleichende Grammatik des sanskrit, send, griechischen, lateinischen, lituanischen, altslavischen, gothischen und deutschen, Berlin: Dümmler 1833-1852.

Woollaston, M. W., A practical grammar of the Sanskrit language, part 1, Calcutta: Serampore Press 1835.

Brown, Thomas Richard, The essentials of Sanskrit grammar, with examples of parsing, Southwick: Brown 1841.

Wilson, Horace Hayman, An introduction to the Grammar of the Sanskrit Language for the use of early Students, London 1841 (wyd. 2 London: J. Madden and Co. 1847; wyd. ind. Varanasi 1961).

Ballantyne, James Robert, $A$ catechism of Sanskrit grammar, London-Edinburgh 1843 (wyd. 3 London 1850 lub 1851).

Desgranges, M., Grammaire sanscrite-française, 2 tomy, Paris 1845-1847. Monier-Williams, Monier, An elementary grammar of the Sanskrit language, partly in the Roman character, arranged according to a new theory, in reference especially to the Classical languages, with short extracts in easy prose, to which is added a selection from the Institutes of Manu, with copious references to the grammar, and an English translation by Monier Williams, London 1846 (wyd. 4 1876).

Westergaard, Niels Ludwig, Sanskrit lasebog med tilhörende ordsamling, Kjöbenhavn 1846.

Boller, Anton, Ausführliche Sanskrit-Grammatik für den öffentlichen und Selbstunterricht, Wien 1847.

Ballantyne, James Rober, First lessons in Sanskrit grammar, with an introduction to the Hitopadesa, Mirzapore 1850 lub 1851 (wyd. 2 1862; wyd. 3 London 1865; wyd. 4 London 1885, reprint Point Loma 1941).

Baudry, Frédéric, Grammaire sanscrite. Résumé élémentaire de la théorie des formes grammaticales du Sanscrit, Paris 1852.

Benfey, Theodor, Handbuch der Sanskritsprache. Zum Gebrauch für Vorlesungen und zum Selbsstudium von Theodor Benfey, Leipzig: F. A. Brockhaus 1852-1854. 
Benfey, Theodor, Kurze Sanskrit-Grammatik zum Gebrauch für Anfänger, Leipzig 1855.

Flecchia, Giovanni, Grammatica Sanscrita, Torino: Marietti 1856.

Monier-Williams, Monier, A Practical grammar of the Sanskrit language, arranged with reference to the Classical languages of Europe, for the use of English students, London: The Clarendon Press 1857 [wyd. 2 Oxford 1857; wyd. 4 Oxford 1876; wyd. ind. Varanasi: Chowkhamba Sanskrit Series Office (Chowkhamba Sanskrit Studies, vol. 21) 1962; reprint New Delhi: Oriental Books Reprint Corporation 1978].

Oppert, Jules, Grammaire sanscrite, Berlin-Paris 1857 (wyd. 2 poprawione Berlin 1864).

Burnouf, Émile-Louis, L. Leupol (pseudonim François-Étienne Leloup de Cheray), Méthode pour étudier la langue sanskrite, Nancy 1859 (wyd. 2 Paris 1861).

Rodet, Leon, Grammaire abrégée de la langue sanscrite, 2 vols., Paris 18591860.

Petrov, P., Sanskritskaja gramatika. 1. Devanagarskij alfavit i ctenie, Moskva 1865.

Müller, Max Friedrich, $A$ Sanskrit Grammar for Beginners in Devanägari and Roman Letters Throughout, London 1866 (wyd. 2 poprawione London 1870).

Boltz, August, Vorschule des Sanskrit in lateinischer Umschrift, Oppenheim 1868.

Giusanni, Carlo, Principii della grammatica Sanscrita. Aggiunti due brani di testo, per esercizio di lettura e traduzione, Torino e Firenze: Loescher 1868 (wydane także jako appendix do Angelo de Guernatis, Piccola Enciclopedia Indiana).

Stenzler, Adolf Friedrich, Elementarbuch der Sanskrit-Sprache. Grammatik, Texte, Woerterbuch, Breslau: M. Mälzer 1868 (1869) (wyd. 2 Breslau 1872; wyd. 3 1875; wyd. 4 Breslau 1880; wyd. 5 1885; wyd. 6 poprawione przez Richarda Pischela, Breslau: Louis Koehler's Hofbuchhandlung 1892; wyd. 7 1902; wyd. 8 1908; wyd. 9 poprawione przez Karla Friedricha Geldnera 1915; wyd. 10 1923; wyd. 11 1939; wyd. 12 1943; wyd. 13 1952; wyd. 14 poprawione i uzupetnione przez Samarendranatha Biswasa; wyd. 15 1965; wyd. 16 1970; wyd. 17 1980; wyd. 18 poprawione przez Albrechta Wetzlera Berlin-New York: Walter de Gruyter 1995). 
Ferrar, William Hugh, A Comparative Grammar of Sanskrit, Greek and Latin, 1869.

Kielhorn, Franz, A Grammar of the Sanskrit Language, Bombay 1870 (wyd. 5 Bombay: Nirnaya Sagar Press 1912; wyd. 6 Varanasi: The Chowkhamba Sanskrit Series Office 1970).

Malinowski, Franciszek, Prospekt na gramatykę sanskrytu porównanego z językiem starosłowianskim i polskim na podstawie sanskryckiej gramatyki Franciszka Boppa, Komorniki pod Poznaniem 1871.

Malinowski, Franciszek, Gramatyka sanskrytu porównanego z jezykiem starosłowiańskim i polskim. Na podstawie sanskryckiej gramatyki Franciszka Boppa napisana przez Ks. Franc. Xaw. Malinowskiego, plebana z Komornik pod Poznaniem, członka Poznańskiego Towarzystwa Przyjaciół Nauk, Poznań: Drukarnia T. H. Daszkiewicza (staraniem Ludwika Rzepeckiego) 1872.

Scherzl, V. I., Sanskritskaja grammatika, vol. 1, Harkov 1873.

Burrit, Elihu, Social walks and talks with young students among the languages; a Sanskrit handbook for the fireside, London 1875.

Bühler, Georg, Third book of Sanscrit, 1877; 1888.

Vasconcellos-Abreu, Guilherme, de, Principios elementares da grammatica da lingua sãoskrita, Lisboa 1879.

Whitney, William Dwight, Indische Grammatik. Umfassend die Klassische Sprache und die älteren Dialecte. Aus dem Englischen übersetzt von Heinrich Zimmer, Leipzig 1879; Hildesheim-New York-Wiesbaden 1980. Whitney, William Dwight, A Sanskrit Grammar, including both the Classical language, and the older dialects of Veda and Brahmana, Leipzig: Breitkopf \& Härtel 1879 (wyd. 2 poprawione i rozszerzone 1889; wyd. 3 London 1896; wyd. 81955 London: Oxford University Press; reprint 1964 Cambridge, MA: Harvard University Press; 1980; wyd. 8 1995; ind. reprint 1962, 1969 Delhi: Motilal Banarsidas).

Rivero, Francisco Maria D., Grammatica elemental del Sanscrito clasico, Madrid 1881.

Vasconcellos-Abreu, Guilherme, de, Manual para o estudo do saoskrito classico, Lisboa 1881.

Bühler, Georg, Leitfaden für den Elementarcursus des Sanskrit: Mit Übungsstücken und Zwei Glossaren von Georg Bühler, Wien: Verlag von Carl Konegen 1883 (wyd. 2 poprawione przez J. Nobel Wien 1927; tłum. polskie Bolesław Baranowski, red. Eugeniusz Słuszkiewicz, Podręcznik sanskrytu, Warszawa 1977). 
Edgren, August Hjalmar, Sanskritsprakets formlaara jaamte kort oofversigt af prakritdialekten samt inledande laasoofnigar, Lund 1883.

Pullè, Francesco Lorenzo, Grammatica sanscrita, Torino: Loescher 1883.

Bergaigne, Abel Henri Joseph, Manuel pour étudier la langue sanscrite.

Chrestomathie - Lexique - Principes de grammaire, Paris: F. Vieweg 1884 (reprint Genève 1984).

Hatfield, James Taft, Elements of Sanskrit Grammar, 1884.

Holtzmann, Adolf, Grammatisches aus dem Mahäbhärata, ein anhang zu William Dwight Whitney's indischer Grammatik, Leipzig 1884.

Perry, Edward Delavan, $A$ Sanskrit Primer; oparte na Leitfaden für den Elementarcursus des Sanskrit [oparte na podręczniku napisanym przez Georga Bühlera, Boston: Ginn 1885 (wyd. 2 1886; reprint 1892, 1895; wyd. 3 1901; reprint 1903, 1904, 1907, 1911, 1915, 1919, 1923, 1927, 1929; wyd. 4 1936; reprint 1943, 1946, 1950, 1953, A Sanskrit primer, New York-London: Columbia University Press; wyd. ind. Delhi 1936, reprint Delhi: Motilal Banarsidass 1978, 1982, 1986, 1988, 1992, 1994, 1997, 1999].

Müller, Max Friedrich, $A$ Sanskrit Grammar for Beginners (new and abridged edition accented and transliterated throughout with a chapter on syntax and an appendix on classical metres by Arthur Anthony Macdonell), London 1886.

Fumi, Fausto Gherardo, Limen indicum. Avviamento allo studio del sanscrito, litographed, Palermo 1887 (wyd. 2 Milano 1891; wyd. 3 poprawione Milano 1905).

Colinet, Philémon, La langue et la littérature sanscrites, deux leccons d'introduction au cours de sanscrit, Gand 1888.

Geiger, Wilhelm, Elementarbuch der Sanskritsprache. Grammatik, Lesestücke und Glossar, München 1888 (wyd. 2 poprawione i rozszerzone Elementarbuch des Sanskrit, unter Berücksichtigung der vedischen Sprache, 3 vols., Strassburg 1909; wyd. 3, z dodatkiem, Berlin-Leipzig 1923).

Kellner, Hermann Camillo, Sävitri. Praktisches Elementarbuch zur Einführung in die Sanskritsprache, ein buch zum Selbstunterrichte für Philologen und gebildets Laien, Leipzig 1888.

Kielhorn, Franz, Grammatik der Sanskrit-Sprache. Aus dem Engl. Übersetzt von W. Solf, Berlin 1888.

Gelabert y Gordiola, Juan, Manual de lengua sanskrita. Crestomatia $\gamma$ gramática, Madrid 1890.

Fick, Richard, Praktische Grammatik der Sanskrit-Sprache für den Selbstunterricht. Mit Uebungsbeispielen, Lesestücken und Glossaren, Wien, Pest, 
Leipzig: A. Hartleben's Verlag 1891 (wyd. 3 Wien-Leipzig 1922; reprint Wiesbaden: Steiner 1983).

Miller, V. F., Knauer, F. I., Rukovodstvo k izucceniju sanskrita. Grammatika, teksty, slovar, Sankt Petersburg 1891.

Müller, Max Friedrich, Max Müller's Sanskrit-Grammatik in Devanagari und lateinischen Buchstaben. Aus dem Englischen übersetzt von F. Kielhorn und G. Oppert, 1892.

Nazari, Oreste, Elementi di grammatica sanscritica. Seguiti da esercizi graduali, antologia e lessico con caratteri Devanāgarī, 1892 (Torino 1948).

Edgren, August Hjalmar, Jamforande grammatik, omfattande Sanskrit, Grekiska, Latin och Gotiska, Gootenburg 1893.

Pizzi, Italo, Grammatica elementare della lingua sanscrita con temi antologia e vocabulario, Torino: Clausen 1896.

Macdonell, Arthur Anthony, Sanskrit Grammar for Beginners, London 1901 (wyd. 2 Oxford 1911; wyd. 3, zatytułowane $A$ Sanskrit Grammar for Students, Oxford 1927; reprinty ind. 1974, 1979, Delhi: Motilal Banarsidass).

\section{Wybory tekstow oryginalnych / Chrestomatie (wybrane przykłady) - alfabetycznie}

Benfey, Theodor, Chrestomathie aus Sanskritwerken: zum Gebrauch für Vorlesungen und zum Selbststudium, Leipzig 1854.

Bergaigne, Abel, Manuel por étudier la langue sanscrite: chrestomathie, lexique, principes de grammaire, 1884.

Bühler, Georg, Third Reading Book for the Use of High Schools. With a glossary by Vishnu S. Pandit, 1883.

Carey, William, $A$ Sungscrit Chrestomathy containing extracts from the $\mathrm{Hi}$ topadeśa, Daśakumaracarita and Bhartrhari, Serampore 1804.

Frank, Othmar, Chrestomathia Sanscritaquam ex codicibus manuscriptis, adhuc inedicis Londini exscripsit atque in usum tironum versione, expositione, tabulis grammaticis etc., illustratam edidit, Monachii 1820-1821.

Gelabert y Gordiola, Juan, Lengua sanskrita: crestomatia y gramática, Madrid 1890.

Hoefer, Albert, Sanskrit-Lesebuch mit Benutzung handschriftlicher Quellen, 1849. 
Lanman, Charles Rockwell, $A$ Sanskrit Reader: with Vocabulary and Notes, Boston 1884-1889.

Lassen, Christianus, Anthologia Sanscritica glossario instructa, Bonn 1838 (wyd. 2 1865; wyd. 3 poprawione 1868).

Leupol, Louis, Burnouf, Émile-Louis, Selectae è sanscriticis scriptoribus paginae; choix de morceaux sanscrits traduits, annotés, analysés, Paris 1867. Pullè, Francesco Lorenzo, Crestomazia sanscrita e vedica, Padova 1878.

Pullè, Francesco Lorenzo, Piccola Crestomazia sanscrita, 1873.

Rodet, Léon, Grammaire abrégée de la langue sanscrite, 1859-1860.

Schmidt, Johannes, Kleine Sanskrit Chrestomathie, Weimar 1868.

Yates, William, The Sunscrit Reader, or easy introduction to the Reading of the

Sunscrit language (w pięciu częściach: 1: Select Sentences; 2: Dialogues; 3:

Duties of Young persons; 4: Fables; 5: Poetical Extracts) (wyd. 1 Calcutta $1821 \mathrm{w}$ alfabecie bengali; wyd. $21822 \mathrm{w}$ alfabecie dewanagari).

\section{Wybory tekstow oryginalnych / Chrestomatie (wybrane przykłady) - chronologicznie}

Carey, William, $A$ Sungscrit Chrestomathy containing extracts from the $\mathrm{Hi}$ topadeśa, Daśakumaracarita and Bhartrhari, Serampore 1804.

Frank, Othmar, Chrestomathia Sanscritaquam ex codicibus manuscriptis, adhuc inedicis Londini exscripsit atque in usum tironum versione, expositione, tabulis grammaticis etc., illustratam edidit, Monachii 1820-1821.

Yates, William, The Sunscrit Reader, or easy introduction to the Reading of the Sunscrit language (w pięciu częściach: 1: Select Sentences; 2: Dialogues; 3: Duties of Young persons; 4: Fables; 5: Poetical Extracts) (wyd. 1 Calcutta $1821 \mathrm{w}$ alfabecie bengali; wyd. $21822 \mathrm{w}$ alfabecie dewanagari).

Lassen, Christianus, Anthologia Sanscritica glossario instructa, Bonn 1838 (wyd. 2 1865; wyd. 3 poprawione 1868).

Hoefer, Albert, Sanskrit-Lesebuch mit Benutzung handschriftlicher Quellen, 1849.

Benfey, Theodor, Chrestomathie aus Sanskritwerken: zum Gebrauch für Vorlesungen und zum Selbststudium, Leipzig 1854.

Rodet, Léon, Grammaire abrégée de la langue sanscrite, 1859-1860.

Leupol, Louis, Burnouf, Émile-Louis, Selectae è sanscriticis scriptoribus paginae; choix de morceaux sanscrits traduits, annotés, analysés, Paris 1867. 
Schmidt, Johannes, Kleine Sanskrit Chrestomathie, Weimar 1868.

Pullè, Francesco Lorenzo, Piccola Crestomazia sanscrita, 1873.

Pullè, Francesco Lorenzo, Crestomazia sanscrita e vedica, Padova 1878.

Bühler, Georg, Third Reading Book for the Use of High Schools. With a glossary by Vishnu S. Pandit, 1883.

Bergaigne, Abel, Manuel por étudier la langue sanscrite: chrestomathie, lexique, principes de grammaire, 1884.

Lanman, Charles Rockwell, $A$ Sanskrit Reader: with Vocabulary and Notes, Boston 1884-1889.

Gelabert y Gordiola, Juan, Lengua sanskrita: crestomatia y gramática, Madrid 1890.

\section{Wybory tekstów pochodzących z określonych dzieł (wybrane przykłady) - chronologicznie}

Johnson, Francis, Hitopadesa: The Sanskrit text of the First Book, or Mitra-Labha; with a grammatical analysis, alphabetically arranged, 1840.

Johnson, Francis, Hitopadesa: The Sanskrit text, with a grammatical analysis, alphabetically arranged, 1840.

Johnson, Francis, Selections from the Mahabharata, 1842.

Müller, Max, Handbooks for the Study of Sanskrit. The Second, Third and Fourth Books of the Hitopadeśa: Containing the Sanskrit Text with Interlinear Translation, 1865.

Leupol, Louis, Spécimen des Purânas. Texte, transcription, traduction et commentaire des principaux passages du Brahmavaearta purâna, 1868.

Monier-Williams, Monier, Nalopakhyanam. Story of Nala, an episode of the Mahabharata: the Sanskrit text, with a copious vocabulary and an improved version of Dean Milman's translation, 1879.

Kellner, Hermann, Camillo, Lied von König Nala. Erstes Lesebuch für Anfänger im Sanskrit, 1885. 


\section{Wybory tekstów pochodzacych z określonych dzieł (wybrane przykłady) - alfabetycznie}

Johnson, Francis, Hitopadeśa: The Sanskrit text of the First Book, or Mitra-Labha; with a grammatical analysis, alphabetically arranged, 1840.

Johnson, Francis, Hitopadeśa: The Sanskrit text, with a grammatical analysis, alphabetically arranged, 1840.

Johnson, Francis, Selections from the Mahabharata, 1842.

Kellner, Hermann, Camillo, Lied von König Nala. Erstes Lesebuch für Anfänger im Sanskrit, 1885.

Leupol, Louis, Spécimen des Purânas. Texte, transcription, traduction et commentaire des principaux passages du Brahmavaearta purâna, 1868.

Monier-Williams, Monier, Nalopakhyanam. Story of Nala, an episode of the Mahabharata: the Sanskrit text, with a copious vocabulary and an improved version of Dean Milman's translation, 1879.

Müller, Max, Handbooks for the Study of Sanskrit. The Second, Third and Fourth Books of the Hitopadesa: Containing the Sanskrit Text with Interlinear Translation, 1865. 


\section{Spis ilustracji}

1. Julian Adolf Święcicki, Historya literatury indyjskiej, strona



2. Roberto Nobili, https://en.wikipedia.org - 20 V 2019 ................. 36

3. Athanasius Kircher, China Illustrata, frontispis, https://en.

wikipedia.org - 20 V 2019

4. Athanasius Kircher, China Illustrata, alfabet sanskrycki, https:// htext.stanford.edu - 20 V 2019

5. Athanasius Kircher, China Illustrata, modlitwa "Pater Noster", https://htext.stanford.edu - $20 \mathrm{~V} 2019$

6. Johann Ernst Hanxleden, https://en.wikipedia.org - 20 V 2019... 64

7. Paulinus a Sancto Bartholomaeo, https://www.anca-aste.it -

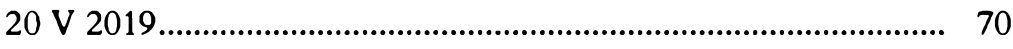

8. William Carey, https://pl.wikipedia.org - 20 V 2019.................. 82

9. James Robert Ballantyne, https://en.wikipedia.org - 20 V 2019 .. 91

10. Charles Wilkins, A Grammar of the Sanskrita Language,

strona tytułowa, https://covers.openlibrary.org - 20 V 2019 ..... 97

11. William Jones, https://pl.wikipedia.org - 20 V 2019 .................... 105

12. Henry Thomas Colebrooke, $A$ Grammar of the Sanscrit

Language, strona tytułowa, https://ia801604.us.archive.org

-20 V 2019

13. Horace Hayman Wilson, https://en.wikipedia.org 20 V 2019.

14. Monier Monier-Williams, https://upload.wikimedia.org - $20 \mathrm{~V}$ 2019.

15. Franz Bopp, https://en.wikipedia.org - 20 V 2019 
16. Theodor Benfey, https://en.wikipedia.org - 20 V 2019

17. Adolf Friedrich Stenzler, https://de.wikipedia.org - $20 \mathrm{~V}$ 2019

18. Georg Bühler, https://pl.wikipedia.org - $20 \mathrm{~V} 2019$ 138

19. Walenty Skorochód Majewski, [w:] J. Handel, Dzieje jezykoznawstwa, Lwów 1935.

20. Franciszek Xawery Malinowski, https://commons.wikimedia. org -20 V 2019

21. Jan Leciejewski, https://pl.wikipedia.org - 20 V 2019 161

22. Antoni Lange, [w:] Upominek. Książka zbiorowa na cześć Elizy Orzeszkowej (1866-1891), https://pl.wikipedia.org - 20 V 2019... 162 23. Julian Adolf Święcicki, https://pl.wikipedia.org - 20 V 2019...... 163 24. William Yates, https://en.wikipedia.org - $20 \mathrm{~V} 2019$ 169

25. Otto von Boehtlingk, https://pl.wikipedia.org - $20 \mathrm{~V} 2019$. 172

26. Rudolph von Roth, https://en.wikipedia.org - 20 V 2019 173

27. Monier Monier-Williams, A Sanskrit-English Dictionary etymologically and philologically arranged with special reference to Greek, Latin, Gothic, German, Anglo-Saxon and other cognate Indo-European languages, karta tytułowa, https://books.google. $\mathrm{pl}-20 \mathrm{~V} 2019$

28. Otto Boehtlingk, Sanskrit Chresthomathie, karta tytułowa, https://www.iberlibro.com - 20 V 2019.

29. Charles Rockwell Lanman, https://en.wikipedia.org 20 V 2019 184

30. Charles Rockwell Lanman, $A$ Sanskrit Reader, with Vocabulary and Notes, https://archive.org - $20 \mathrm{~V} 2019$ 186 


\section{Bibliografia}

A History of Indian Literature, red. Jan Gonda, Wiesbaden: Otto Harrassowitz 1973-1984.

Aklujkar, Ashok, Sanskrit. An Easy Introduction to an Enchanting Language, 3 tomy w czterech częściach, Vancouver: British Columbia: Department of Asian Studies, University of British Columbia 1990 (wyd. 2 2002; wyd. 3 2003; wyd. 4 2005).

Andrijanić, Ivan, $A$ List of Sanskrit and Latin Cognates in Vesdin's Treatise De Latini Sermonis Origine, „The Journal of Indo-European Studies" 2017, vol. 45, nr 3-4, s. 195-233.

Apte, V. S., The Student's Sanskrit-English Dictionary, containing appendices on Sanskrit prosody and important literary and geographical names in the ancient history of India, Delhi 1890.

A Reader on the Sanskrit Grammarians, red. Johan Frederik Staal, Delhi 1985. Ballantyne, James Robert, The Laghukaumudī. A Sanskrit Grammar by Varadaraja. With an English Version, Commentary and References, Benares 1849.

Basham, Arthur L., The Wonder that was India. A survey of the history and culture of the Indian sub-continent before the coming of the Muslims, Delhi: Rupa and Co. 1985 (wyd. 1 1954; thum. polskie: Indie. Od poczq̨tku dziejów do podboju muzułmańskiego, przeł. Zygmunt Kubiak, Warszawa: Państwowy Instytut Wydawniczy 1964).

Bhagawadgita, czyli Pieśn o Bogu. Poemat filozoficzny indyjski, przeł. Stanisław F. Michalski-Iwieński, Warszawa: Ultima Thule 1927.

Bhagawadgita. Pieśn Czcigodnego Pana, przeł., komentarzem i objaśnieniami opatrzyła Marta Kudelska, Kraków: Oficyna Literacka 1995.

Bhagawadgita, czyli Pieśn Pana, przeł. z sanskrytu i przypisy Joanna Sachse, Wrocław-Warszawa-Kraków-Gdańsk-Łódź: Zakład Narodowy im. Ossolińskich 1988. 
Bhagawadgita, czyli Pieśn Czcigodnego, przeł. z sanskrytu i oprac. Joanna

Sachse, Wrocław: Instytut Studiów Klasycznych i Śródziemnomorskich 2019.

Bhagawad Gita. Pieśn Pana, przeł. Wanda Dynowska, Madras 1947. Bhagawadgita. Święta Pieśn Pana, przeł. z sanskrytu i oprac. Anna Rucińska, Warszawa: Wydawnictwo Sawitar 2002.

Bhartrhari, Bhartrhariego strof trzykroć po sto: o mądrości życia, o namiętności miłosnej i o wyrzeczeniu, przeł. Ireneusz Kania, Kraków: Wydawnictwo Literackie 1980.

Brockington, John, William Carey's significance as an Indologist, niepublikowany artykuł (w posiadaniu autorki).

Bronkhorst, Johannes, Greater Magadha. Studies in the Culture of Early India, Leiden-Boston: Brill 2007.

Butryn, Roksana, Bramini w liście Świętego Franciszka Ksawerego. Sociis Romae degentibus Cocino 15 Ianuarii 1544, „Studia Indologiczne" 2001, vol. 8, s. 5-24.

Bühler, Georg, Podręcznik sanskrytu, przeł. Bolesław Baranowski, Warszawa: Akademia Teologii Katolickiej 1977.

Byrski, Krzysztof Maria, Indyjska koncepcja cywilizacyjna, Warszawa-Rzym, 1979.

Byrski, Krzysztof Maria, O czym mówi literatura indyjska, czyli wspótrzędne indyjskiej rzeczywistości, „Literatura na Świecie” 1980, vol. 114, nr 10, s. $158-179$.

Byrski, Krzysztof Maria, Dramat staroindyjski. Bhasa - Kalidasa, przeł., wstęp i oprac. Maria Krzysztof Byrski, Wrocław: Zakład Narodowy im. Ossolińskich 2017.

Camps, Arnulf, Father Heinrich Roth, S.J. and the History of his Sanskrit Manuscripts by Arnulf Camps, OF.M., [w:] The Sanskrit Grammar and Manuscripts of Father Heinrich Roth S.J. (1620-1668), facsimile edition of Biblioteca Nazionale, Rome, Mss. Or. 171 and 172, Leiden-New York-København-Köln: E. J. Brill 1988, s. 5-12.

Chatterji, Suniti, Kumar, Sir William Jones, [w:] Portraits of Linguists: A Biographical Source Book for the History of Western Linguistics, 1746-1963, vol. 1: From Sir William Jones to Karl Brugmann, red. Thomas A. Sebeok, Bloomington-London: Indiana University Press 1966, s. 18-24.

Cieślikowski, Sławomir, Teoria literatury $w$ dawnych Indiach. $Z$ dodanymi tekstami Cezarego Galewicza, Huberta Hładija, Lucyny Lipowskiej i Lidii 
Sudyki, red. Lucyna Lipowska, Hubert Hładij, Kraków: Księgarnia Akademicka 2016.

Colebrooke, Henry Thomas, On the Sanscrit and Pracrit Languages, [w:] Asiatic Researches, or transactions of the society instituted in Bengal, for inquiring into the history and antiquities, the arts, sciences and literatures of Asia, vol. 7, London 1803, s. 199-231.

Coulson, Michael, (Teach Yourself) Sanskrit. An Introduction to the Classical Language, London: Hodder and Stoughton, revised by Richard Gombrich 1976 (reprint 1990; wyd. 21992 revised by Richard Gombrich, James Benson, Elizabeth Kelsall; reprint 1992, 1995, 1996, 1997, 1998; wyd. 3 2003, 2006).

Corder, Stephen, Pit, Introducing applied linguistics, London-New York-

Victoria-Toronto-Auckland: Penguin Books 1993 (wyd. 2 1973).

Czterdzieści pieśni Rigwedy, przeł. Stanisław Franciszek Michalski, Warszawa-Kraków: Wydawnictwo Ultima Thule 1912.

Deshpande, Madhav M., Samskritasubodhini. A Sanskrit primer, Ann Arbor:

Center for South and Southeast Asian Studies 1997 (reprint 1999).

Diringer, David, Alfabet, czyli klucz do dziejów ludzkości, Warszawa:

Państwowy Instytut Wydawniczy 1972.

Edgerton, Franklin, Sir William Jones, [w:] Portraits of Linguists: A Biographical Source Book for the History of Western Linguistics, 1746-1963, vol. 1: From Sir William Jones to Karl Brugmann, red. Thomas A. Sebeok, Bloomington-London: Indiana University Press 1966, s. 1-18.

Encyklopedia jezzkoznawstwa ogólnego, red. Kazimierz Polański, WrocławWarszawa-Kraków: Zakład Narodowy im. Ossolińskich 1995 (wyd. 2 poprawione i uzupetnione 1999).

Filliozat, Jean, Une grammaire sanscrite du XVIIIe siècle et les débuts de l'indianisme en France, .Journal Asiatique" 1937, vol. 229, s. 275-284.

Gawroński Archiwum, Materiały dotyczące Andrzeja Gawrońskiego z archiwum Uniwersytetu Jagiellońskiego.

Gawroński, Andrzej, Poczq̨tki dramatu indyjskiego a sprawa wpływów greckich, wstęp Eugeniusz Słuszkiewicz, Kraków 1946.

Gawroński, Andrzej, Podręcznik sanskrytu. Gramatyka, wypisy, objaśnienia, słownik, Kraków: Polska Akademia Umiejętności 1932, wydany z rękopisu odnalezionego w zbiorze tekstów pozostałych po śmierci autora w oprac. Heleny Willman-Grabowskiej i Jana M. Rozwadowskiego (wyd. 2 Lublin 1985; wyd. 3 poprawione 2004). 
Goldman, Robert, Sutherland, J. Sally, Devavānipraveśikā. An Introduction to the Sanskrit language, Berkeley: Center for South and Southeast Asia Studies, University of California 1980 (wydania poprawione 1987, 1992, 1999, 2002, 2004, 2011).

Gonda, Jan, Kurze Elementar-Grammatik der sanskrit-Sprache mit übungsbeispielen, lesestücken und einem glossar, Leiden: E. J. Brill 1941 (reprint 1943, 1948, 1963; thum na j. angielski $A$ Concise Elementary Grammar of the Sanskrit language, Leiden 1966; thum. na j. francuski z j. niemieckiego, $\mathrm{z}$ wyd. $4 \mathrm{R}$. Rocher Manuel de grammaire élémentaire de la langue sanskrite suivi d'exrcices, de morceux choisis et d'un lexique. Addenda et Corrigenda. Index de notions grammaticales. Indes des éléments grammaticaux. Index des mots par Boris Oguiénine, Paris: J. Maisonneuve 1993).

Grammatica Grandonica: The Sanskrit Grammar of Johann Ernst Hanxleden S.J. (1681-1732), red. Christophe Vielle, Toon Van Hal, Potsdam: Universitätverlag 2013.

Griffiths, Bede, Złota nić. Chrześcijański aśram, Kraków 1974 (przeł. Joanna Mroczkowska; oryginał The golden string, London 1954; Christian Ashram, London 1956).

Guz, Marzena, Franciszek Ksawery Malinowski als Wissenschaftler, „Prace Językoznawcze" 1999, z. 1, s. 33-40.

Halbfass, Wilhelm, Indie $i$ Europa. Próba porozumienia na gruncie filozoficznym, tłum. polskie $\mathbf{z}$ j. angielskiego Monika Nowakowska, Robert Piotrowski, Warszawa 2008 (India and Europe. An Essay in Philosophical Understanding, Delhi: Motilal Banarsidass Publishers 1990).

Handel, Jakób, Dzieje językoznawstwa, Lwów: Biblioteka Filomaty 1935. Hansen, Waldemar, Pawi tron. Dramat Indii Wielkich Mogotów, Warszawa 1980 (The Peacock Throne. The Drama of Moghul, przeł. Jerzy Schwakopf, India 1972).

Hauschild, Richard, Zum Inhalt der drei Handschriften Roths, [w:] Zeitschrift für Missionswissenschaft und Religionswissenschaft, Münster 1969, vol. 53, s. $195-202$.

Hauschild, Richard, Notes on the Content of the Three Manuscripts of Heinrich Roth (translated into English and revised by Jean-Claude Muller), [w:] The Sanskrit Grammar and Manuscripts of father Heinrich Roth S.J. (1620-1668), facsimile edition of Biblioteca Nazionale, Rome, Mss. Or. 171 and 172 with an introduction by Arnulf Camps and Jean-Claude Muller SJ, Leiden-New York-København-Köln 1998, s. 13-19. 
Heinz, Adam, Dzieje jęzkoznawstwa w zarysie, Warszawa: Państwowe Wydawnictwo Naukowe 1978.

Herodot, Dzieje, z j. greckiego przeł. i oprac. Seweryn Hammer, Warszawa: Czytelnik 2003.

Higginbotham, J. J., Men whom India has known. Biographies of eminent Indian characters, Madras: Higginbotham and Co. 1874.

Hobby, James, Memoir of William Yates D. D., of Calcutta. With an Abridgment of his Life of W. H. Pearce, London: Houlston \& Stoneman, Paternoster Row. 1847.

Hock, Hans Henrich, Sanskrit as a spoken language: dead, dying, or still alive, niepublikowany manuskrypt (w posiadaniu autorki).

Hymny Rigwedy, przeł. z sanskrytu, wstępem i komentarzem opatrzył Stanisław Franciszek Michalski (posłowie, wstęp, komentarz, uzupełniła i do druku przygotowała G. Spychalska), Wrocław: Zakład Narodowy im. Ossolińskich 1971.

Jauk-Pinhak, Milka, Some notes on the pioneer indolgist Filip Vesdin (Paulinus a Sancto Bartholomaeo), „Indologica Taurinensia” 1984, vol. 12, s. $129-137$.

Jones, William, A Descriptive Poem by Calidas in the Original Sanscrit, Calcutta 1792.

Kadyńska-Szajnert, Danuta, O niektórych aspektach przet.u z literatury indyjskiej na jezyk polski, [w:] Wielojezycznośc literatury i problemy przet.u artystycznego, vol. 64, red. Edward Balcerzan, s. 171-183, $Z$ dziejów form artystycznych $w$ literaturze polskiej.

Kalidasa, Dramat staroindyjski. Bhasa - Kalidasa, przeł., wstęp i oprac. Maria Krzysztof Byrski, Wrocław: Zakład Narodowy im. Ossolińskich 2017. Kalidasa, Rozpoznanie Śakuntalowica. Dramat niespłaconego dtugu wobec przodków (akt I, II i IV), przeł. Maria Krzysztof Byrski, [w:] Światło stowem zwane. Wypisy z literatury staroindyjskiej, praca zbiorowa pod red. Marka Mejora, Warszawa: Wydawnictwo Akademickie DIALOG 2007, s. 772-816.

Kalidasa, Rozpoznanie Śakuntalowica. Dramat w siedmiu aktach, przeł. Stanisław Schayer, oprac. Eugeniusz Stuszkiewicz, [w:] Dramat staroindyjski. Bhasa - Kalidasa, przeł., wstęp i oprac. Maria Krzysztof Byrski, Wrocław: Zakład Narodowy im. Ossolińskich 2017.

Kalidasa, Śakuntala czyli pierścień fatalny. Dramat heroiczny w siedmiu aktach, przeł. z oryginału indyjskiego, wstępem i objaśnieniami opatrzył Sta- 
nisław Schayer, Warszawa: Instytut Wydawniczy "Bibljoteka Polska" 1923.

Kalidasa, Siakuntala, przeł. Stanisław Schayer, oprac. Eugeniusz Słuszkiewicz, Wrocław: Ossolineum 1957.

Kālidāsa, Meghadūta. Obłok - Posłańcem, przeł. z sanskrytu, wstęp i przypisy Joanna Sachse, Katowice: Verbum 1994.

Kamińska-Jones, Dorota, Kobieta, sztuka $i$ kolonizacja. Wizerunki kobiet $w$ strefie kontaktu indyjsko-brytyjskiego, Toruń: Wydawnictwo Naukowe Uniwersytetu Mikołaja Kopernika 2017.

Kämasūtram Vatsyāyany. Indyjska Ars Amatoria. Wraz z kompletnym komentarzem (Jayamańgalā) Yaśodhary. Oryginat w sanskrycie, Lwów: Wydawnictwo Kultura i Sztuka 1922.

Karp, Artur, Indyjska wieża Babel, „Literatura na Świecie” 1980, vol. 114, nr 10, s. 130-139.

Karttunen, Klaus, India in early Greek literature, Helsinki: Finnish Oriental Society 1989, Studia Orientalia, vol. 65.

Karttunen, Klaus, India and the Hellenistic World, Helsinki: Finnish Oriental Society 1997, Studia Orientalia, vol. 83.

Karttunen, Klaus, Greeks and Indian Wisdom, „Poznań Studies in the Philosophy of the Sciences and the Humanities" 1997, vol. 59, s. 117-121. Karyekar, Madhuvanti, Fostering aesthetic tolerance through literary translation: Georg Foster's Sakuntalā, [w:] Transcultural Encounters between India and Germany. Kindred spirits in the nineteenth and twentieth centuries, red. Joanne Miyang Cho, Eric Kurlander, Douglas T. McGetchin, London: Routledge 2013.

Keith, Berriedale A., A History of Sanskrit Literature, Delhi: Motilal Banarsidass Pulishers 1996 (wyd. 1 indyjskie Delhi 1993).

Kieniewicz, Jan, Faktoria i forteca. Handel pieprzem na oceanie indyjskim i ekspansja portugalska $w$ XVI wieku, Warszawa: Państwowe Wydawnictwo Naukowe 1970.

Kieniewicz, Jan, Portugalczycy w Azji: $X V-X X$ wiek, Wrocław-Warszawa-Kraków-Gdańsk: Zakład Narodowy im. Ossolińskich 1976. Kieniewicz, Jan, Historia Indii, Wrocław-Warszawa-Kraków-Gdańsk: Zakład Narodowy im. Ossolińskich 1980.

Kieniewicz, Jan, Drogi do Indii, Warszawa: Krajowa Agencja Wydawnicza 1983.

Kieniewicz, Jan, Orientalizm. Idea kształtujq̨ca rzeczywistośc, ${ }_{n}$ Rocznik Orientalistyczny" 1985, nr 1-4, s. 9-30. 
Kieniewicz, Jan, Wprowadzenie do historii cywilizacji Wschodu $i$ Zachodu, Warszawa: Wydawnictwo Akademickie DIALOG 2003.

Kieniewicz, Jan, Contact, Conquest and Colonialism on the Malabar Coast, "Rocznik Orientalistyczny" 2007, nr 2, s. 325-333.

Killingley, Dermot, Teaching Sanskrit in the Modern World, STIMW 1996. Kołdrzak, Elżbieta, Śakuntala [Abhidźńanaśakuntalam]. Dramat staroindyjski Kalidasy, Łódź: Wydawnictwo Uniwersytetu Łódzkiego 2014.

Krnic, Kresimir, Sanskrtska pocetnica, Zagreb: Izdavac Nebo na zemlji d.o.o. 1995.

Lange, Antoni, Pieśn o Nalu i Damajanti. Baśn staroindyjska z ksiqg Mahabharaty, przeł. z sanskrytu, przedmowa Antoni Lange, Warszawa: Gabriel Centneszwer i s-ka 1906 (reprint Warszawa-Kraków: Jakub Mortkowicz 1913; wyd. 2 Warszawa-Kraków: Jakub Mortkowicz 1921).

Lange, Antoni, Epos indyjskie. Valmiki. Ramayana, Brody 1909.

Lange, Antoni, Epos indyjskie. Vyasa. Mahabharata, [w:] Zbiór arcydziet (poezyi epickiej wszystkich czasów i narodów $w$ streszczeniach $i$ wyciqgach ułożyt A. Lange), Brody 1911.

Lange, Antoni, O Walentym Skorochodzie Majewskim w Warszawskim Towarzystwie Naukowym, Warszawa 1917.

Leciejewski, Jan, Nal. Powieść staroindyjska, „Ateneum” 1885, vol. 2, z. 2, s. 273-324.

Leskien, August, Bopp, [w:] Portraits of Linguists: A Biographical Source Book for the History of Western Linguistics, 1746-1963, vol. 1: From Sir William Jones to Karl Brugmann, red. Thomas A. Sebeok, Bloomington-London: Indiana University Press 1966, s. 207-218.

Literatura indyjska. Antologia, [w:] Wielka literatura powszechna, vol. 5, Warszawa 1932, s. 43-121.

Łozowska, Alicja, Bhagawadgita w polskich przeł.ach, ${ }_{n}$ Przegląd Orientalistyczny" 2008, vol. 226-227, nr 3-4, s. 137-152.

Łozowska, Alicja, Metodologia badań przeł.ów Bhagawadgity, "Wratislaviensium Studia Classican 2017-2018, vol. 37-38, nr 6-7, s. 94-103.

Macdonell, Arthur Anthony, $A$ History of Sanskrit literature, Delhi: Motilal Banarsidass Publishers 1990 (wyd. 1 London 1900, London 1917; reprint Delhi 1971, 1986).

McGetchin, Douglas, Indology, Indomania, and Orientalism. Ancient India's Rebirth in Modern Germany, Madison-Teaneck: Fairleigh Dickinson University Press 2009. 
Majewski Skorochód, Walenty, Brahmawaiwarta-Puranam, Osnowa przez Adolfa Stenzlera Pomorzanina w roku 1829 ogłoszona a przez W. S. Majewskiego Podlasianina na polskie brzmienie wyrazów sanskryckich przepisana $i$ innym Stawianom poświęcona, $w$ Warszawie 1830, Warszawa 1830. Mahulkar, D. D., The Prātiśäkhya Tradition and Modern Linguistics, Baroda: Department of Linguistics, Faculty of Arts, M.S. University Baroda 1981.

Manu Swajambhuwa, Manusmryti, czyli Traktat o Zacności, przeł. z oryginału sanskryckiego, wstępem, przedmową, przypisami i słowniczkiem opatrzył Maria Krzysztof Byrski, Warszawa: Unia Wydawnicza ${ }_{n} \mathrm{C} \& \mathrm{~S}^{n}$ 1992.

Matchett, Freda, The Blackwell Companion to Hinduism, red. Gevin Flood, Bodmin: Blackwell Publishing Ltd. 2003.

Maurer, Walter Harding, The Sanskrit Language: An Introductory Grammar and Reader, 2 vols., Richmond: Curzon Press 1995.

Mejor, Marek, Sanskryt, Warszawa: Wydawnictwo Akademickie DIALOG 2000 (wyd. 2 poprawione Sanskryt, Warszawa: Wydawnictwo Akademickie DIALOG 2004).

Mencel, Tadeusz, Majewski (Skorochód-Majewski) Walenty, [w:] Polski słownik biograficzny, vol. 19, Wrocław-Warszawa-Kraków-Gdańsk: Zakład Narodowy im. Ossolińskich-Wydawnictwo Polskiej Akademii Nauk 1974, s. 195-197.

Michalski, Stanisław, Epos indyjskie i epos greckie, „Nauka i Sztuka” 1948, R. IV, vol. 7, s. 3-14.

Milewska, Iwona, First European Missionaries on Sanskrit Grammar, [w:] Christian and Missionaries in India. Cross-Cultural Communication Since 1500. With Special Reference to Caste, and Colonialism, red. Robert Eric Frykenberg, London: Routledge Curzon 2003, s. 62-69.

Milewska, Iwona, Dzieje poznawania sanskrytu przez Europejczyków. I. najstarsza europejska gramatyka sanskrytu, "Biuletyn Glottodydaktyczny" 2004, vol. 11, s. 93-101.

Milewska, Iwona, How to teach Sanskrit? Didactic aspect of the European Sanskrit grammars - a historical survey, "Cracow Indological Studies" 2008, vol. 10, s. 191-216.

Milewska, Iwona, Andrzej Gawron'ski. Portrait of the Polish Linguist, Sanskritologist and Translator, [w:] Figures pionnières de l'Orientalisme: convergences Européenes, Paris-Bures-sur-Yvette: Groupe pour l'Étude de la Civilisation du Moyen-Orient 2011, s. 243-250, Res Orientales. 
Milewska, Iwona, Main Currents in the European Tradition of Sanskrit Grammars, [w:] Proceedings of the 15th World Sanskrit Conference. Vyäkarana Across the Ages, red. George Cardona, Delhi: DK Printworld 2013, s. 1-29.

Milewska, Iwona, Parallels and differences in methods applied to linguistic studies by multi-linguists Andrzej Gawronski and Konstanty Regamey, [w:] Tradition and Innovation in the History of Linguistics. Contributions from the 13th International Conference on the History of the Language Sciences (ICHoLS XIII), Vila Real, 25-29 August 2014, red. Carlos Assunção, Gonçalo Fernandes, Rolf Kemmler, Münster: Nodus Publikationen 2016, s. 238-248.

Milewska, Iwona, Pierwsze łacińskie opisy gramatyki sanskrytu, „Nowy Filomata" 2016, vol. 20, nr 1, s. 43-55.

Milewska, Iwona, Nala and Damayanti - Indian Epic Love Story in the European Literary Tradition, [w:] Rethinking Orient. In Search of Sources and Inspirations, red. Adam Bednarczyk, Magdalena Kubarek, Maciej Szatkowski, Frankfurt am Main: Peter Lang 2017, s. 127-141.

Milewska, Iwona, Pan-slavism ideology as shown in Sanskrit grammars in Polish, „Wratislaviensium Studia Classica” 2017-2018, vol. 37-38, nr 6-7, s. 297-306.

Milewski, Tadeusz, Jezykoznawstwo, Warszawa: Państwowe Wydawnictwo Naukowe 1965.

Milman, Henry Hart, Nala and Damayanti and Other Poems. Translated from the Sanskrit into English Verse, Oxford 1835 (reprint Oxford 2006). Muller, Jean-Claude, Recherches sur les premières grammaires manuscrites $d u$ Sanskrit, „Bulletin d'Études Indiennes" 1985, vol. 3, s. 125-144.

Muller, Jean-Claude, Bibliography of Heinrich Roth, S.J. by Jean-Claude Muller, [w:] The Sanskrit Grammar and Manuscripts of Father Heinrich Roth S.J. (1620-1668), facsimile edition of Biblioteca Nazionale, Rome, Mss. Or. 171 and 172, Leiden-New York-København-Köln: E. J. Brill 1988 , s. 23-25.

Mundadan, Mathias A., An Unknown 'Oriental Scholar': Ernst Hanxleden (Arnos Pathiri), "Indian Church History Review" 1989, vol. 23, s. 39-63. Muru, Cristina, Early Descriptors and Descriptions of South Asian Languages from the 16th Century Onwards, ,Journal of Portuguese Linguistics" 2018, vol. 17, nr 8, s. 1-29.

Mylius, Klaus, Chrestomathiender Sanskritliteratur, Leipzig: VEB 1981. 
Mylius, Klaus, Historia literatury staroindyjskiej, przeł. Leon Żylicz, Warszawa: Wydawnictwo Akademickie DIALOG 2004 (Geschichte der Literatur im Alten Indien, Leipzig 1983).

Nalus, carmen sanscritum e Mahabharato, edidit, latine vertit, et adnotationius illustravit Franz Bopp, London 1819 (wyd. 2 Maha-Bharati episodium. Textus sanscritus cum interpretatione latina et adnotationibus criticis, Berlin: Nicolai 1832; thum. na j. niemiecki Franz Bopp Nalus und Damajanti, eine indische Dichtung aus dem Sanskrit übersetzt, Berlin: Nicolai 1838). Original Papers illustrating the History of the Application of the Roman Alphabet to the Language of India, red. M. Monier-Williams, London: Longman, Brown, Green, Longmans, and Roberts 1859.

Panikkar, Kavalam Madhava, Dzieje Indii, przeł. Klemens Kęplicz, Warszawa: Państwowe Wydawnictwo Naukowe 1965.

Panikkar, Kavalam Madhava, Azja a dominacja Zachodu. Epoka Vasco da Gamy w dziejach Azji (1498-1945), przeł. Klemens Kęplicz, Warszawa 1972.

Paulinus a Sancto Bartholomaeo (Vesdin, Filip), Amarasinha, sectio prima; de caelo, ex tribus ineditis codicib us manuscriptis curante P. Paulino a S. Bartholomaeo, Romae: Apud Antonium Fulgonium 1798.

Prestage, Edgar, Afonso de Albuquerque. Governor of India. His life, conquests and administration, Watford 1929.

Rocher, Ludo, Paulinus a Sancto Bartholomaeo and the History of Languages in India and Europe, "Brahmavidya" 1961, vol. 25, s. 321-352.

Rocher, Ludo, Paulinus a Sancto Bartholomaeo on the Kinship of the Languages of India and Europe, "The Adyar Library Bulletin” 1961, vol. 25, nr 1-4, s. 321-352.

Rocher, Ludo, Paulinus a Sancto Bartholomaeo, Dissertation on the Sanskrit Language, a reprint of the original Latin text of 1790 , together with an introductory article, a complete English translation, and an index of sources, Amsterdam: John Benjamins Publishing Company 1977. Rocher, Rosane, New Data for the Biography of the Orientalist Alexander Hamilton, ,Journal of the American Oriental Society" 1970, vol. 90, s. 426-448.

Rocher, Rosane, The knowledge of Sanskrit in Europe until 1800, [w:] History of the Language Sciences, vol. 2, Berlin-New York: Walter de Gruyter 2001, s. 1156-1163.

Roth, Heinrich, The Sanskrit Grammar and Manuscripts of Father Heinrich Roth S.J. (1620-1668), facsimile edition of Biblioteca Nazionale, Rome, 
Mss. Or. 171 and 172, red. Arnulf Camps, Jean-Claude Muller, Leiden-New York-København-Köln: E. J. Brill 1988.

Rothermund, Dietmar, The German intellectual quest for India, Delhi: Manohar 1986.

Sachse, Joanna, Megasthenes o Indiach, Wrocław: Wydawnictwo Uniwersyteru Wrocławskiego 1981.

Sachse, Joanna, Ze studiów nad Bhagawadgita, Wrocław: Wydawnictwo Uniwersytetu Wrocławskiego 1988.

Said, Edward Wadie, Orientalizm, przeł. Monika Wyrwas-Wiśniewska, Poznań: Zysk i S-ka 2005.

Said, Edward Wadie, Myśli o wygnaniu, „Literatura na Świecie” 2008, vol. 446-447, nr 9-10, s. 40-58.

Said, Edward Wadie, Nieprzynależny, "Literatura na Świecie" 2008, vol. 446-447, nr 9-10, s. 5-39.

Scharfe, Hartmut, Grammatical Literature, [w:] A History of Sanskrit Literature, vol. 5, part 2, red. Jan Gonda, Wiesbaden: Otto Harrassowitz 1977. Schayer, Stanisław, O filozofowaniu Hindusów. Artykuły wybrane, wybór i wstęp Marek Mejor, Warszawa: Państwowe Wydawnictwo Naukowe 1988.

Schayer, Stanisław, Literatura indyjska, [w:] Wielka literatura powszechna, vol. 1, Warszawa 1930.

Schurhammer, Georg, Na morzach Wschodu. Święty Franciszek Ksawery apostot Indii. 1506-1552, przeł. Stanisław Cieślak, Kraków 1997.

Sebeok, Thomas A., Portraits of Linguists. A Biographical Source Book for the History of Western Linguistics, 1746-1963, vol. 1-2, BloomingtonLondon: Indiana University Press 1966.

Słuszkiewicz, Eugeniusz, O polskich podróżnikach do Indii, „Indo-Asian Culture" 1961, vol. 9, nr 4.

Stasiak, Stefan, Les Indes Portugaises à la fin du XVIe siècle d'après la Relation du voyage fait à Goa en 1596 par Christophe Pautowski, gentilhomme polonais, „Rocznik Orientalistyczny" 1925 , vol. 3, s. 1-56.

Stenzler, Adolf Friedrich, Primer of the Sanskrit language translated into English with some revision by Renate Söpowinien byc znak diakrytyczny zamiast dwóch ohnen, London: School of Oriental and African Studies, University of London 1992.

Stenzler, Adolf Friedrich, Samskrtska pocetnica, przeł. Kresimir Krnic, Zagreb: Izdavac Nebo na Zemlji d.o.o. 1995. 
Sternbach, Ludwik, India as described by mediaeval European travellers, Supplement to ${ }_{n}$ Bhāratīya Vidyā̄ 1946 , vol. 7, nr 5/6, s. 5-33.

Światło stowem zwane. Wypisy z literatury staroindyjskiej, praca zbiorowa pod red. Marka Mejora, Warszawa: Wydawnictwo Akademickie DIALOG 2007.

Święcicki, Julian Adolf, Historya literatury indyjskiej, (Historya literatury powszechnej $w$ monografijach $z$ ilustracyami oryginalnie napisana przez J. A. Święcickiego, vol. 4: Literatura indyjska), Warszawa: Drukarnia A. T. Jezierskiego 1901.

Thapar, Romila, Sakuntala. Text, Readings, Histories, Columbia: Columbia University Press 2011.

The Impeachment of Warren Hastings. Papers from a Bicentenary Commemoration, red. Geoffrey Carnall, Colin Nicholson, Edinburgh 1989.

Theater of Memory. The Plays of Kalidasa, red. Barbara Stoler Miller, New York: Columbia University Press 1984.

Transcultural Encounters between India and Germany. Kindred spirits in the nineteenth and twentieth centuries, red. Joanne Miyang Cho, Eric Kurlander, Douglas T. McGetchin, New York: Routledge 2014.

Tuczyński, Jan, Motywy indyjskie w literaturze polskiej, Warszawa: Państwowe Wydawnictwo Naukowe 1981.

Upaniszady, przeł. i wstępem opatrzyła Marta Kudelska, Kraków: Oficyna Literacka 1998.

Van Hal, Toon, Language comparison in Paulinus a Sancto Bartholomaeo (1748-1806): aims, methodological principles, „Bulletin d'Études Indiennes" 2004-2005, nr 22/23, s. 323-336.

Van Hal, Toon, Protestant Pioneers in Sanskrit Studies in the Early 18th Century. An overlooked chapter in South Indian missionary linguistics, "Historiographia Linguistica” 2016, vol. 43, nr 1/2, s. 99-144.

Velho, Alvaro, Relacja z wyprawy Vasco da Gamy do Indii, przeł. Elżbieta Milewska, wstęp i red. nauk. Jan Kieniewicz, Gdańsk: Novus Orbis 1996.

Watsjajana, Mallanaga, Kamasutra, czyli Traktat o Miłowaniu, przeł. z oryginału sanskryckiego, wstępem, przedmową, przypisami i słowniczkiem opatrzył Maria Krzysztof Byrski, Warszawa: Unia Wydawnicza "C\&S" 1992.

Wąsik, Zdzisław, General Linguistics in the History of the Language Sciences in Poland. Late 1860s-late 1960s, [w:] Towards a History of Linguistics in Poland. From the early beginnings to the end of the 20th century, red. Ernst 
Frideryk Konrad Koerner, Aleksander Szwedek, Amsterdam-Philadelphia: John Benjamins Publishing Company 2001, s. 3-51.

Wielińska, Małgorzata, Gramatyka - jej początki i miejsce w tradycji indyjskiej, "Studia Indologiczne" 1994, vol. 1, s. 133-143.

Wielińska-Soltwedel, Małgorzata, Walenty Skorochód-Majewski. The precursor of Polish Indological Studies, "Rocznik Orientalistyczny" 2007, nr 2, s. $157-170$.

Willman-Grabowska, Helena, Indianistyka $w$ Polsce i studia jej pokrewne, [w:] Szkice z dziejów polskiej orientalist $\gamma k i$, vol. 1, red. Stefan Strelcyn, Warszawa: Państwowe Wydawnictwo Naukowe 1957, s. 237-250.

Winternitz, Maurice, A History of Indian Literature, vol. 1 (thum. z oryginału niemieckiego V. Srinivasa Sharma) (foreword 1907), Delhi: Motilal Banarsidass Publishers 1990 (Geschichte der Indischen Literatur, vol. 1-3, Leipzig 1904-1920).

Wüthrich-Sarnowska, Maria Mariola, Polish Translations of the Bhagavadgitā, "Asiatische Studien" 1996, vol. 50, nr 3, s. 673-680.

Yates, William, The Nalodaya or History of King Nala, with Metrical Translation, Kalkuta 1844.

Yuyama, Akira, A Select bibliography on the Sanskrit language for the use of students in Sanskrit, Tokyo 1982.

$Z$ hymnów Rigwedy. Bogowie trojga światów, przeł. Cezary Galewicz, Halina Marlewicz, wybrał i wstępem opatrzył Cezary Galewicz przy współpracy Haliny Marlewicz, Kraków: Oficyna Literacka 1996.

Zimmel, Bruno, $A$ List of the letters, reports and manuscripts written by Father Heinrich Roth, translated and revised by Arnulf Camps, O.M.P., [w:] The Sanskrit Grammar and Manuscripts of Father Heinrich Roth S.J. (16201668), facsimile edition of Biblioteca Nazionale, Rome, Mss. Or. 171 and 172, Leiden-New York-København-Köln: E. J. Brill 1988, s. 20-22. 



\section{Summary}

7 he main goal of this book is to present the tradition of the European Sanskrit grammars written within the period from the seventeenth up to the nineteenth century. The book consists of seven main parts and a number of chapters.

As the first modern contacts between Europe and India began in the fifteenth century and they have been continued in many areas up to the present times, the book starts with short information on this topic. Already at the turn of fifteenth and sixteenth centuries first Europeans found their way to India. They set out in the quest for discoveries of new lands. At the very beginning they were looking for "Christians and spices", as noted in W. Halbfass's book India and Europe. An Essay in Philosophical Understanding. Thus, this period may be called the period of travellers and merchants. They were soon followed by missionaries who promptly started to show interest in the languages of India, among them in Sanskrit.

Since the research on the grammars of Sanskrit written by Europeans is the major focus of the book, and their history is presented in chronological order, the first detailed description and analysis concerns the grammar written by father Heinrich Roth. The manuscript of this grammar was discovered only in the twentieth century, but it most probably dates back to 1660 . This is why the European tradition of descriptions of Sanskrit grammars may be said to have begun in the seventeenth century. 
The eighteenth century follows with some other grammars written, and the end of it is marked by the publication of the first European Sanskrit grammar in Europe, written by a Croatian missionary Paulinus a Sancto Bartholomaeo.

Meanwhile, at the turn of eighteenth and nineteenth centuries some more important grammars are prepared and published by Europeans both in India and in Europe. They are by William Carey, Charles Wilkins, and Henry Thomas Colebrooke, to mention only some of the most important authors. The presentation of these major achievements in the field of description of Sanskrit grammar together with the analyses of the content of the works constitute another part of this book.

The nineteenth century is the period when many more grammars were written and published; therefore the next part of the book focuses on those. Among others the works of the European linguists such as Franz Bopp or Adolf Stenzler are presented and analysed.

Two Polish nineteenth century Sanskrit grammars, by Walenty Skorochód Majewski and Franciszek Xawery Malinowski, are looked into in a separate part.

All the aforementioned as well as some other grammars are presented and analysed in terms of their content in order to show the main currents of the European tradition of Sanskrit grammars of this period in a synthetical perspective.

Two short informative parts concerning selected bilinguial dictionaries and chresthomatias of fragments of Sanskrit texts written and published during this period come next. They were and still are important tools for those interested in Sanskrit.

The content of the book is preceded with an introduction in which an outline of the issues discussed is given, and followed by a chapter concluding the conducted research.

The book also includes bibliography of the major sources consulted while writing and several appendices. The first two appendices are: 
the alphabetically-organised list of authors of the European Sanskrit grammars and the titles of their works, and the chronologically-organised version of this list of works. Another two appendices provide information on the selected bilinguial Sanskrit dictionaries. These are also arranged in both alphabetical and chronological order according by the names of their authors. 



\section{Indeks osobowy}

Aklujkar Ashok 18, 59

Albuquerque Alfonso de 30

Aleksander Wielki 27

Almeida Francisco de 29

Andrijanić Ivan 18, 69

Anquetil-Duperron Abraham Hyacinthe

$71,75,148$

Aurangzeb 45

Ballantyne James Robert 19, 21, 90-91, $93,138,171$

Baranowski Bolesław 139

Basu Munshi Ramram 83

Baudouin de Courtenay Jan 154

Benfey Theodor 20, 22, 72, 119, 130-

$133,173,188$

Beschi Joseph 41, 71

Bhartrihari 60, 89, 132, 173

Blau Otto 175

Boehtlingk Orto von 113, 131-132, 163 ,

172-174, 177, 180, 183, 187-189

Bopp Franz 20, 22, 70, 76, 107, 116, 123 -

$129,135,150-151,155-156,158-$

159, 163-164, 169, 171-173, 188, 193

Britto John 40

Brockington John 83-84, 86-87

Bronkhorst Johannes 10

Brunnhofer Hermann 175

Burnouf Eugène 76
Burnouf Jean-Louis 76, 116

Burton Richard 178

Bühler Georg 20, 22, 137-139, 175, 185, 193

Byrski Maria Krzysztof 29, 106, 108, 178-179

Camps Arnulf 17, 45-46, 48, 50-51, 59

Cappeller Carl 175

Carey William 19, 21, 82-90, 94, 128, 147

Cegielski Hipolit 123, 154-155

Chézy Antoine-Léonard de 62, 76, 116, $124,135,148$

Cieszkowski August 155

Cieślikowski Sławomir 133

Colebrooke Henry Thomas 19, 21, 76, $89,96,108-114,125,128,171,173-$ 174, 192

Coulson Michael 91, 185

Dynowska Wanda 95

Edgerton Franklin 36, 107

Eichhorn Johann Gottfried 148

Erman Adolf 48

Euringer Sebastian 50

Fick Richard 163

Flood Gavin 68 
Forster Henry P. 128, 148

Forster Reinhold 73

Foster Georg 106

Franciszek Ksawery, św. 31-32

Frank Othmar 116, 189

Fuller Andrew 86

Gama Vasco da 29

Gawroński Andrzej 101, 137, 164

Geldner K. F. 136

Goethe Wolfgang 106

Goldman Robert P. 189

Goldstücker Theodor 167

Gombrich Richard 10

Gonda Jan 57

Goressi 132

Gotsch Antoni 148

Gough Archibald Edward 175

Griffiths Bede 39

Grueber Johann 48

Grzegorz XV 40

Guz Marzena 154

Haeberlin John 132

Hal Toon Van 17, 39, 72

Halbfass Wilhelm 27, 34, 37-40, 68, 83

Halde Jean-Baptiste du 61

Halhed Nathaniel 96

Hamilton Alexander 115-116, 124

Hamilton William 115

Hammer Seweryn 28

Hanxleden Johann Ernst 17, 21, 63-67,

72, 192

Hastings Warren 94

Haughton Graves Champney 173

Hauschild Richard 17, 51, 58

Heine Heinrich 107

Heinz Adam 128-129
Herder Johann Gotffried 60, 107

Herodot z Halikarnasu 28

Hervás y Panduro Lorenzo 49

Higginbotham J. J. 32, 89, 109

Hogarth Edward Lucas 175

Holtzmann Adolf 188

Homer 86

Humboldt Wilhelm von 107, 125

Hütner J. C. 108

Jacobi Johann Georg 107

Jauk-Pinhak Milka 18, 69

Johnston E. H. 171

Johnston Frederick William 73

Jones William 22, 35, 76-77, 96, 104$109,111,146,148$

Kalidasa 56, 100, 106-107, 134-136, 173, 179

Kania Ireneusz 60

Karttunen Klaus 10, 28, 33, 75

Kielhorn Franz 135, 163, 175, 188

Kieniewicz Jan 37, 40, 67

Kircher Athanasius 47-49, 71

Kołdrzak Elżbieta 106

Korus Kazimierz 10

Kosegarten Johann Gottfried Ludwig $76,124,132,135$

Krnic Kresimir 137

Kuczkiewicz-Fraś Agnieszka 146-147

Kudelska Marta 95

Kühn A. 132

Lange Antoni 161-162

Langlès Louis-Mathieu 124

Lanman Charles Rockwell 184-187

Lassen Christian 76, 127, 171-173, 189

Leciejewski Jan 160-161 
Leibniz Gotffried 48

Leumann Ernst 175

Libelt Karol 155

Linder F. Joseph 50

Łozowska Alicja 95

Oliveria Manoel de 34

Panini 89, 98, 110-111, 113, 117

Patańdżali 110

Pawłowski Krzysztof 33

Percival P. 108

Perry Edward Delavan 139

Macdonell Arthur Anthony 139, 179, 193 Piekarski Przemysław 10

Malinowski Franciszek Xawery 23, 126, Piętka Tomasz 147

150, 153-160

Marlewicz Halina 10

Marshman Hannah 82-83

Marshman Joshua 82-83, 85, 89

Matchett Freda 68-69

Mejor Marek 164

Mencel Tadeusz 146

Michalak-Pikulska Barbara 10

Michalski-Iwieński Stanisław Franciszek 95

Milewska Iwona 33, 125, 156

Milewski Tadeusz 129-130

Milewski Zdobysław 11

Milman Henry Hart 120

Molesworth James Thomas 171

Monier-Williams Monier 22, 31, 37 . $46,57,116-120,168-171,174-180$, 186,188

Mroczkowska Janina 39

Muir John 93

Muller Jean-Claude $17,35,51,58-59$. 62-63

Müller Max 72, 123, 188

Mylius Klaus 184

Nobili Roberto 21, 36-40, 46

Nowakowska Monika 27

Oberhammer Gerhard 9
Piotrowski Robert 27

Pischel Richard 136

Pius X 33

Podolak Barbara 146, 152

Pons Jean François 61-63, 115

Pujo J. 38

Rajamanickam S. 38

Reland (Relandus) Hadrianus 28

Riddle Joseph Esmond 171

Rocher Ludo 18, 68-71, 74, 77

Rocher Rosane 115

Rogerius Abraham 59-60

Rosen Friedrich August 126

Roth Heinrich 17, 21, 45-59, 63, 184185,192

Roth Rudolph von 172-174, 177, 180, 188

Ruciríska Anna 95

Ryland John 87

Rzepecki L. 154

Sachse Joanna 10, 95, 135

Sacy Antoine Isaac Silvestre de 124, 135

Sancto Bartholomaeo Paulinus a 18, 21, $65,67,69-77,147,149,192$

Sassetti Filippo 33

Scharfe Hartmut 57, 113

Schayer Stanisław 106

Schiller Friedrich 107 
Schlegel August Wilhelm 76, 107, 116, Vielle Christophe 17, 39, 72 $123,125,135,172$

Schlegel Friedrich Wilhelm 62, 72, 107, Ward William 83-85

116,148

Schmidt Richard 178

Schultze Benjamin 61

Sebeok Thomas Albert 36

Skorochód Majewski Walenty 23, 28-29, $126,145-153,156,160$

Słuszkiewicz Eugeniusz 106

Staal Johan Frederik 129

Stasiak Stefan 33

Staszic Stanisław 146

Stenzler Adolf Friedrich 20, 22, 123, 134137, 151, 173

Stephens (Stevens) Thomas 34

Surcliffe John 86

Sutherland Sally J. 189

Szahdżahan 45

$\begin{array}{ll}\text { Zachariae Theodor } 50 \\ \text { Zicki Julian Adolf 27-28, 162-163 } & \text { Zimmel Bruno 17, } 50\end{array}$
Wąsik Zdzisław 146

Weber Albrecht 184

Westergaard Niels Ludwig 171, 177

Wetzler Albrecht 136

Whitney William Dwight 177, 184, 187

Wielińska Małgorzata 152

Wilkins Charles 19, 21, 76, 94-104, 109, 115-116, 125, 128, 192

Wilson Horace Hayman 76, 114, 132 , 167-169, 171, 173, 177, 180, 192

Windischmann Karl Joseph Hieronymus 123, 127

Winternitz Maurice 174

Yates William 128, 169, 171, 189 





Monografia dr hab. Iwony Milewskiej ma wyjątkowy, pionierski charakter: z jednej strony odpowiada na pytanie, kiedy kontakty przedstawicieli dwóch zasadniczo różniących się cywilizacji indyjskiej i europejskiej, obok od wieków trwających relacji handlowych, weszły na poziom intelektualny, a z drugiej, w jaki sposób Europa przyjmowała elementy kultury indyjskiej wraz z klasyczną literaturą. Cezurę jakościową wyznacza Autorka na wiek XVII, kiedy pierwsi nowożytni misjonarze docierają do Indii, uczą się miejscowych języków, a ich sposób życia wpisuje się w codzienność mieszkańców. Bardzo szybko przekonują się, że warunkiem dotarcia $z$ nową nauką do najwyższej warstwy społeczeństwa indyjskiego, braminów, jest poznanie sanskrytu, klucza otwierającego ich literacką kulturę...

Fragment recenzji prof. Kazimierza Korusa 